\title{
Characterization and Occurrence of Confined and Unconfined Aquifers in Quaternary Sediments in the Glaciated Conterminous United States
}

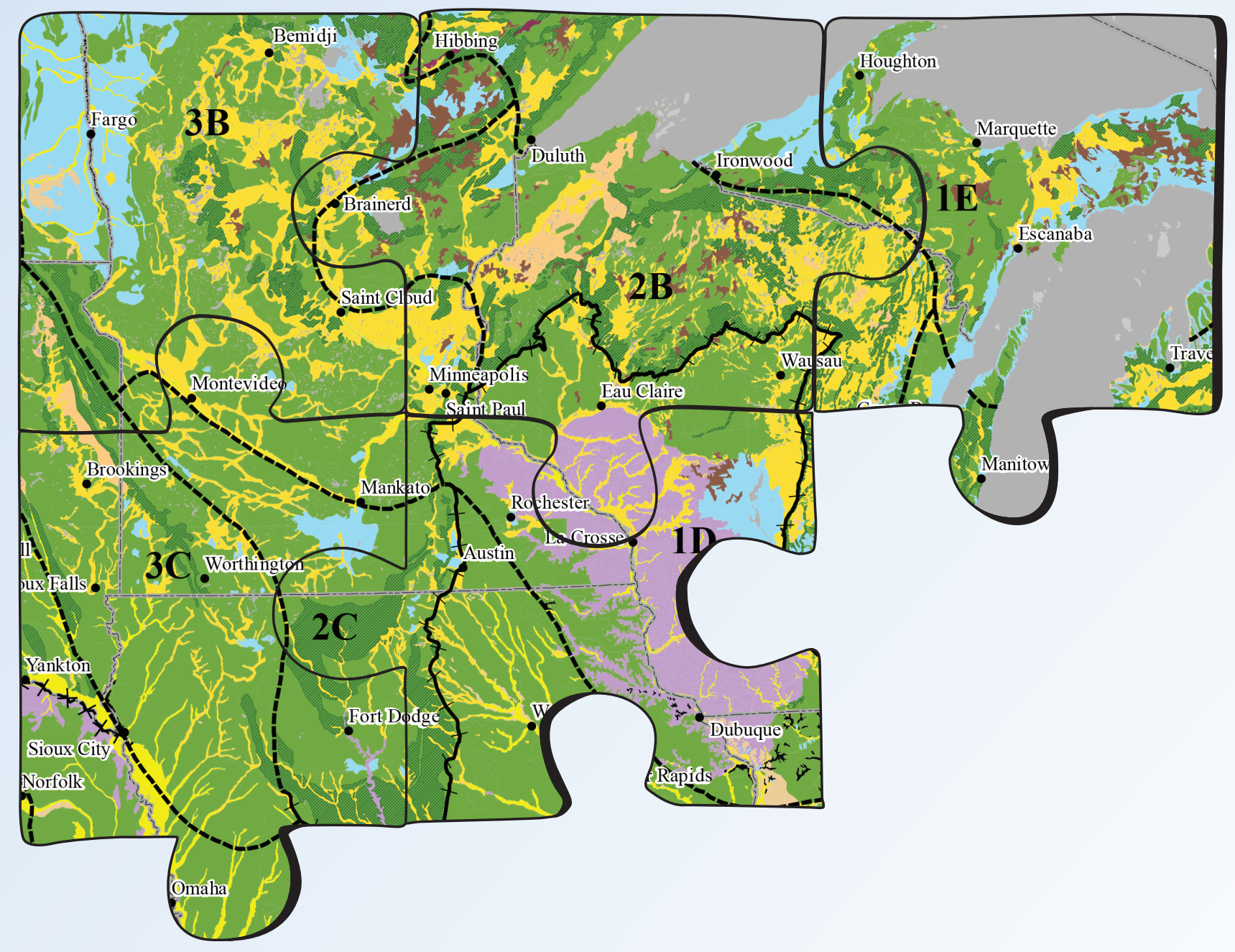

Scientific Investigations Report 2018-5091

Version 1.1, February 2019 
Cover. Puzzle pieces showing hydrogeologic terranes of the northern Midwest part of the map of the contiguous United States; from figure 5 of this report. 


\section{Characterization and 0ccurrence of Confined and Unconfined Aquifers in Quaternary Sediments in the Glaciated Conterminous United States}

By Richard M. Yager, Leon J. Kauffman, David R. Soller, Adel E. Haj, Paul M. Heisig, Cheryl A. Buchwald, Stephen M. Westenbroek, and James E. Reddy

Scientific Investigations Report 2018-5091

Version 1.1, February 2019 


\title{
U.S. Department of the Interior DAVID BERNHARDT, Acting Secretary
}

\author{
U.S. Geological Survey \\ James F. Reilly II, Director
}

\author{
U.S. Geological Survey, Reston, Virginia \\ First release: 2018 \\ Revised: February 2019 (ver. 1.1)
}

For more information on the USGS - the Federal source for science about the Earth, its natural and living resources, natural hazards, and the environment-visit https://www.usgs.gov or call 1-888-ASK-USGS.

For an overview of USGS information products, including maps, imagery, and publications,

visit https://store.usgs.gov.

Any use of trade, firm, or product names is for descriptive purposes only and does not imply endorsement by the U.S. Government.

Although this information product, for the most part, is in the public domain, it also may contain copyrighted materials as noted in the text. Permission to reproduce copyrighted items must be secured from the copyright owner.

Suggested citation:

Yager, R.M., Kauffman, L.J., Soller, D.R., Haj, A.E., Heisig, P.M., Buchwald, C.A., Westenbroek, S.M., and Reddy, J.E., 2019, Characterization and occurrence of confined and unconfined aquifers in Quaternary sediments in the glaci-ated conterminous United States (ver. 1.1, February 2019): U.S. Geological Survey Scientific Investigations Report 20185091, 90 p., https://doi.org/10.3133/sir20185091.

ISSN 2328-0328 (online) 


\section{Acknowledgments}

The authors thank Richard Soule, Minnesota Department of Health, for his suggestions concerning the construction of interpolated maps of sediment and aquifer characteristics. We also thank Les Arihood, Scientist Emeritus, U.S. Geological Survey (USGS), for his assistance in interpreting water-well drillers' records for the lithologic database and Sue Kahle, USGS hydrologist, for her contribution to the discussion of glacial geology in the northwestern United States. Finally, we thank Tom Nolan, USGS hydrologist, for his application of the dendrogram analysis in the comparison of sediment and aquifer characteristics of hydrogeologic terranes. 



\section{Contents}

Acknowledgments ……...................................................................................................................

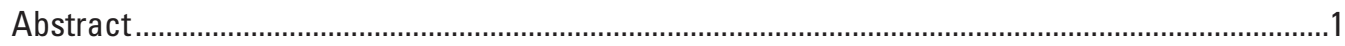

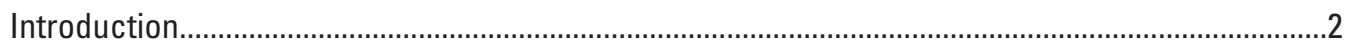

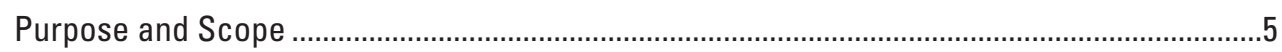

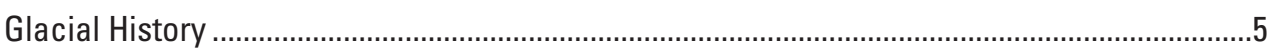

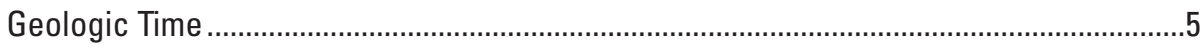

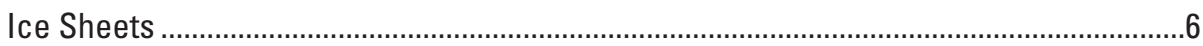

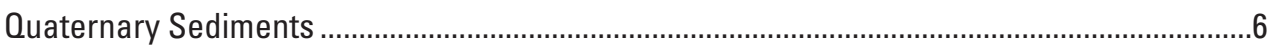

Aquifers in Quaternary Sediments..........................................................................................

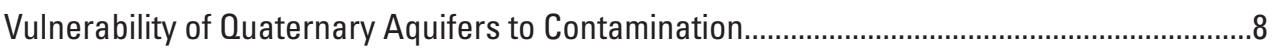

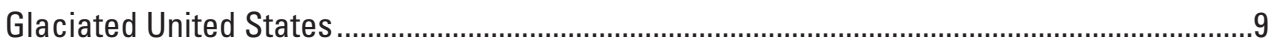

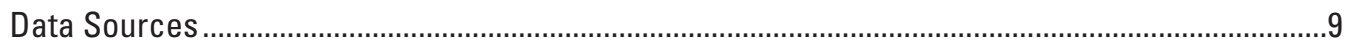

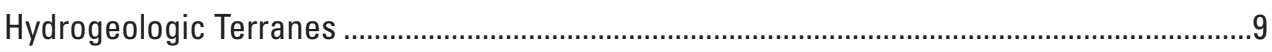

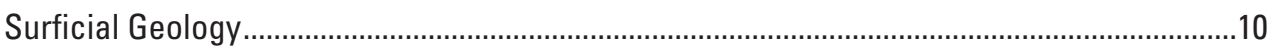

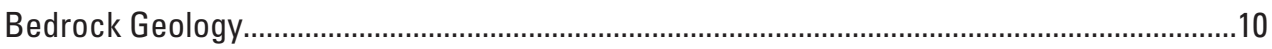

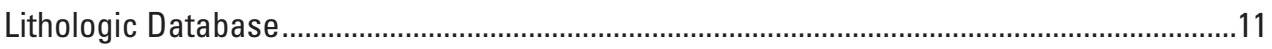

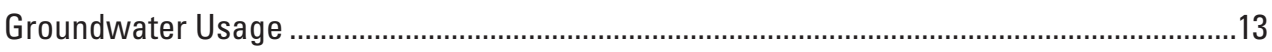

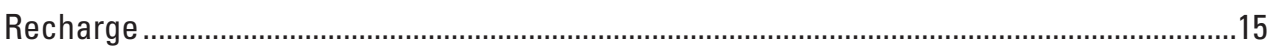

Quaternary Sediment in the Glaciated Conterminous United States............................................15

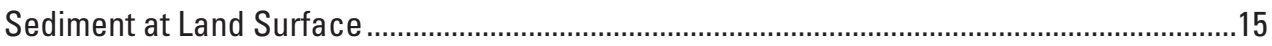

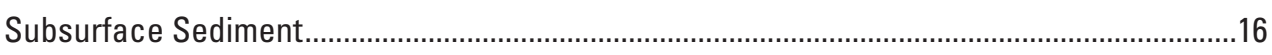

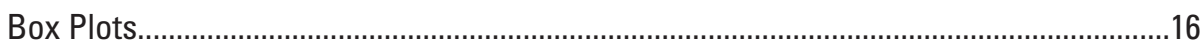

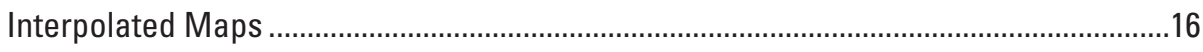

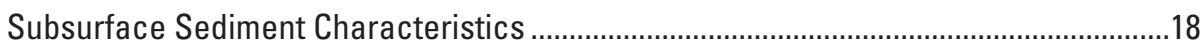

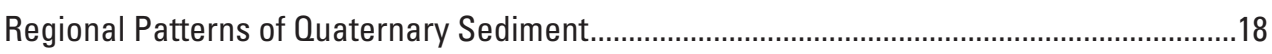

Confined and Unconfined Aquifers in Quaternary Sediments in the Glaciated

Conterminous United States...........................................................................................18

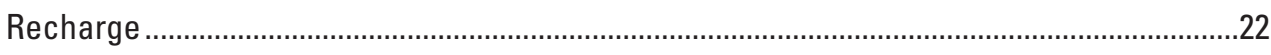

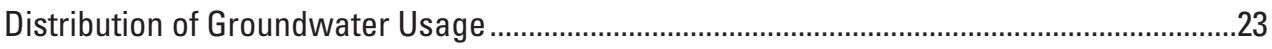

Sediment and Aquifer Characteristics of Hydrogeologic Terranes ...............................................26

Hydrogeologic Terranes of Lower Complexity.......................................................................30

Terrane 1A—Predominantly Late Wisconsinan Sediment in Eastern Ohio Through New England ..................................................................................30

Terrane 1B-Generally Pre-Late Wisconsinan Sediment in Southern Ohio,

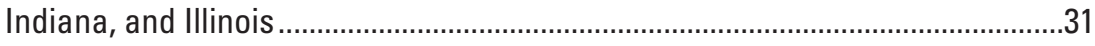

Terrane 1C—Older, Partially Eroded Glacial Sediments in Central Missouri ..................37

Terrane 1D—Older, Partially Eroded Glacial Sediments Around the Driftless Area ......39

Terrane 1E-Late Wisconsinan Sediment Near Lakes Superior and Michigan..............41

Terrane 1F-Thin Late Wisconsinan Sediment in Montana and North Dakota..............41

Terrane 1G_-Residuum and Sediment From the Cordilleran Ice Sheet.........................43

Hydrogeologic Terranes of Moderate Complexity ..............................................................45

Terrane 2A-Predominantly Late Wisconsinan Sediment, Notably With Buried

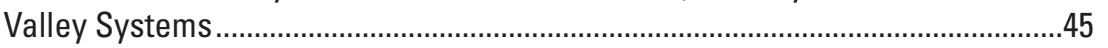

Terrane 2B — Late Wisconsinan Sediment From Lake Superior Lobe ...........................49 
Terrane 2C—Late Wisconsinan Sediment in the Des Moines Lobe ...............................51

Terrane 2D—Older Sediment in lowa and Kansas .........................................................51

Terrane 2E-Late Wisconsinan Sediment in the Dakotas...............................................53

Hydrogeologic Terranes of Higher Complexity .......................................................................55

Terrane 3A-Interlobate Area in Southern Michigan Between Lake Michigan, Saginaw, and Lake Huron-Erie Lobes................................................................5

Terrane 3B-Interlobate Area in Minnesota Between Labrador and Keewatin

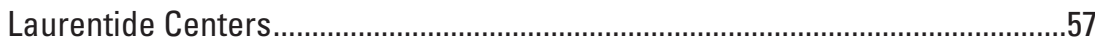

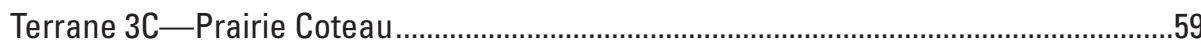

Hydrogeologic Terranes with Thick Coarse-Grained, Stratified Quaternary Sediment..........61

Terrane 4A—Long Island and Cape Cod.....................................................................61

Terrane 4B_Eastern Nebraska .....................................................................................64

Interpretation of Surficial and Subsurface Data .....................................................................66

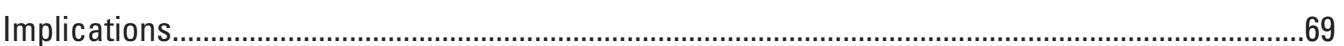

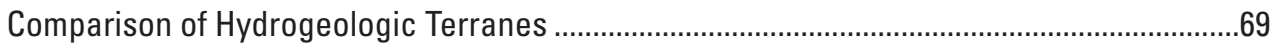

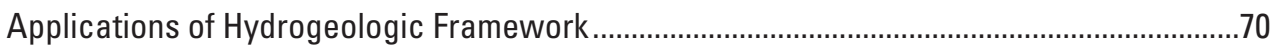

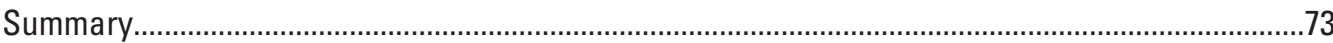

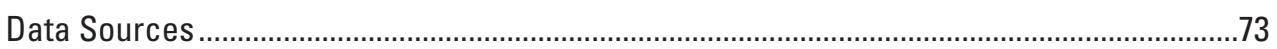

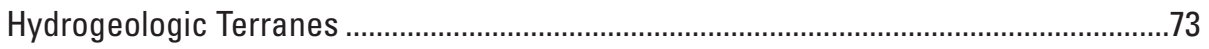

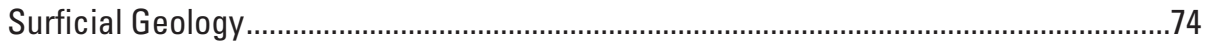

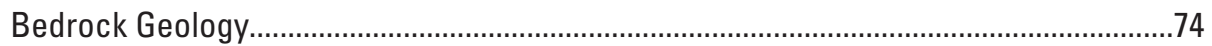

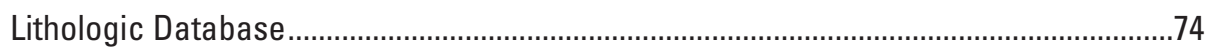

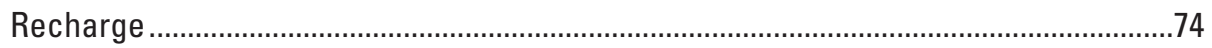

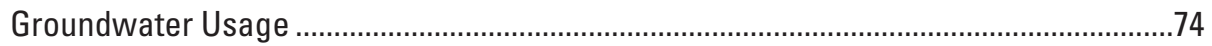

Quaternary Sediment and Aquifers .................................................................................

Characteristics of Hydrogeologic Terranes ………….....................................................

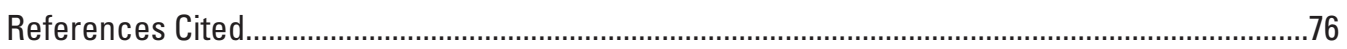

Appendix 1. Development and Application of the Soil-Water Balance Model to the

Glaciated Conterminous United States .............................................................................81

\section{Figures}

1. Map showing hydrogeologic terranes and the maximum glacial advance in the glaciated conterminous United States.....

2. Maps showing glacial features, by hydrogeologic terrane, in the glaciated United States

3. Schematic diagram showing examples of unconfined, semiconfined, and confined aquifers Quaternary sediments

4. Map showing hydrochemical regions in the glaciated conterminous United States

5. Map showing Glacial Environment and Surficial Sediments geodatabase map units in the glaciated conterminous United States.

6. Map showing textural classification of Glacial Environment and Surficial Sediments geodatabase map units in the glaciated conterminous United States.

7. Map showing generalized bedrock lithology and overlying Glacial Environment and Surficial Sediments geodatabase coarse-grained, stratified surficial sediments in the glaciated conterminous United States 
8. Map showing density of lithologic logs aggregated on a 5-kilometer grid in the glaciated conterminous United States...

9. Schematic diagram showing variables computed from lithologic logs in the glaciated conterminous United States.

10. Pie chart showing percentages of land surface in the glaciated conterminous United States covered by principal

11. Box plots showing metrics computed from lithologic logs grouped by map unit in the glaciated conterminous United States

12. Maps showing metrics of Quaternary sediment, estimated from lithologic logs, in the glaciated conterminous United States.

13. Profile plots showing the frequency distribution of coarse and fine materials with depth beneath map units in the glaciated conterminous United States

14. Maps showing aquifer-material intervals penetrated by lithologic logs in the glaciated conterminous United States.

15. Pie chart showing number of aquifer-material intervals penetrated by lithologic logs in the glaciated conterminous United States

16. Box plots showing metrics computed from lithologic logs grouped by map unit in the glaciated conterminous United States.

17. Maps showing aquifer characteristics, estimated from lithologic logs, in the glaciated conterminous United States.

18. Pie charts showing percentages of water wells in the glaciated conterminous United States

19. Box plots showing water wells completed in Quaternary sediment by hydrogeologic terrane in the glaciated conterminous United States.

20. Maps showing confined and unconfined aquifer-material interval characteristics in the glaciated conterminous United States

21. Map showing annual recharge in the glaciated conterminous United States based on the soil-water balance model

22. Box plots showing annual recharge by hydrogeologic terrane in the glaciated conterminous United States

23. Maps showing distribution of groundwater use, by county, in the glaciated conterminous United States

24. Map showing annual groundwater withdrawals in 2010 as a ratio to recharge, by county, in the glaciated conterminous United States.

25. Bar chart showing proportions of map units within each hydrogeologic terrane in the glaciated conterminous United States.

26. Box plots showing sediment and coarse material characteristics grouped by hydrogeologic terrane in the glaciated conterminous United States

27. Box plots showing aquifer-material interval characteristics grouped by hydrogeologic terrane in the glaciated conterminous United States..

28. Bar charts showing water well characteristics grouped by hydrogeologic terrane in the glaciated conterminous United States

29. Map showing comparison of extent of coarse-stratified sediment from Kontis and others (2004) and the Glacial Environment and Surficial Sediments geodatabase

30. Box plots showing aquifer characteristics by topographic setting in terrane $1 \mathrm{~A}$ in the glaciated conterminous United States.

31. Bar charts showing aquifer characteristics by topographic setting in terrane $1 \mathrm{~A}$ in the glaciated conterminous United States. 
32-45. Box plots showing aquifer characteristics by topographic setting in the glaciated conterminous United States:

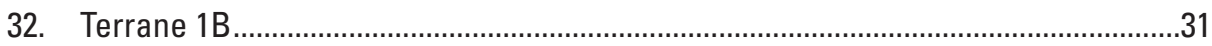

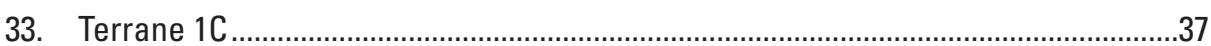

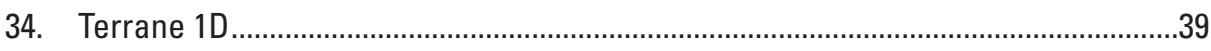

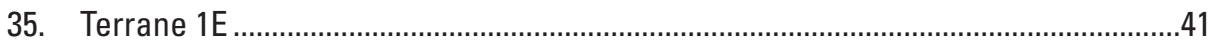

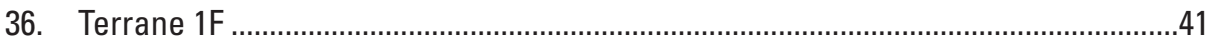

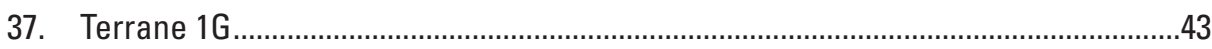

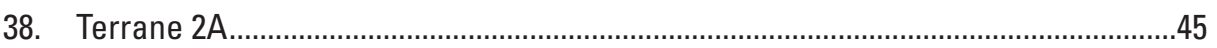

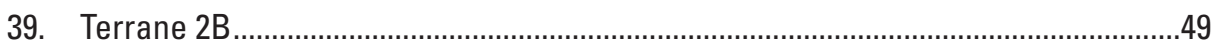

40. Terrane 2C

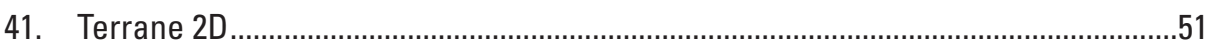

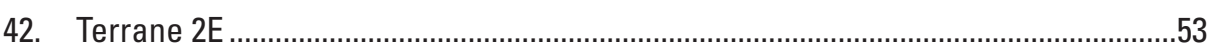

43. Terrane 3A

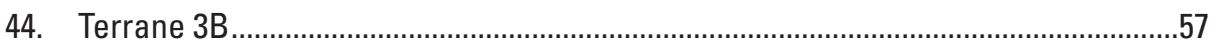

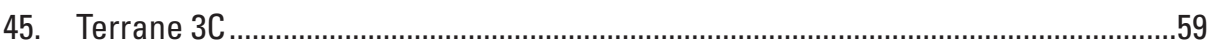

46. Pie charts showing distributions of map units in terrane $4 A$ in the glaciated conterminous United States for $A$, Cape Cod and $B$, Long Island ....................................64

47. Box plots showing aquifer characteristics by topographic setting in terrane $4 \mathrm{~A}$ in the glaciated conterminous United States.

48. Bar charts showing aquifer characteristics beneath Cape Cod and Long Island in terrane $4 \mathrm{~A}$ in the glaciated conterminous United States

49. Box plots showing aquifer characteristics by topographic setting in terrane $4 B$ in the glaciated conterminous United States.

50. Maps showing selected confined and unconfined aquifers in Illinois and Indiana in the glaciated conterminous United States.

51. Maps showing selected confined and unconfined aquifers in North Dakota in the glaciated conterminous United States.

52. Tree diagram showing similarities and dissimilarities among hydrogeologic terranes in the glaciated conterminous United States

\section{Tables}

1. Use of groundwater in the glaciated conterminous United States in 2010

2. Principal map unit categories and descriptions included in the hydrogeologic framework of the glaciated conterminous United States.

3. Lithologic logs and water wells, by State, in the glaciated conterminous United States

4. Lithologic logs, by hydrogeologic terrane, in the glaciated conterminous United States.

5. Variables used in lithologic logs in the glaciated conterminous United States. 14

6. Comparison of aquifer material and water-well metrics from lithologic database for the glaciated conterminous United States. 


\section{Conversion Factors}

International System of Units to U.S. customary units

\begin{tabular}{lcl}
\hline \multicolumn{1}{c}{ Multiply } & \multicolumn{1}{c}{ By } & \multicolumn{1}{c}{ To obtain } \\
\hline millimeter $(\mathrm{mm})$ & 0.03937 & inch (in.) \\
meter $(\mathrm{m})$ & 3.281 & foot (ft) \\
kilometer $(\mathrm{km})$ & 0.6214 & mile (mi) \\
\hline \multicolumn{2}{c}{ Area } & \\
\hline square kilometer $\left(\mathrm{km}^{2}\right)$ & 247.1 & acre \\
square kilometer $\left(\mathrm{km}^{2}\right)$ & 0.3861 & square mile $\left(\mathrm{mi}^{2}\right)$ \\
\hline & Flow rate & \\
\hline cubic meter per year $\left(\mathrm{m}^{3} / \mathrm{yr}\right)$ & 811.03 & acre-foot per year $(\mathrm{acre}-\mathrm{ft} / \mathrm{yr})$ \\
millimeter per year $(\mathrm{mm} / \mathrm{yr})$ & 0.03937 & inch per year $(\mathrm{in} / \mathrm{yr})$ \\
\hline
\end{tabular}

\section{Datum}

Vertical coordinate information is referenced to the North American Vertical Datum of 1988 (NAVD 88).

Horizontal coordinate information is referenced to the North American Datum of 1983 (NAD 83).

Elevation, as used in this report, refers to distance above the vertical datum.

\section{Supplemental Information}

Geologic time is given in years before present (yBP).

\section{Abbreviations}

GESS

Glacial Environments and Surficial Sediments [geodatabase]

SWB

soil-water balance [model]

USGS

U.S. Geological Survey 



\title{
Characterization and Occurrence of Confined and Unconfined Aquifers in Quaternary Sediments in the Glaciated Conterminous United States
}

\author{
By Richard M. Yager, Leon J. Kauffman, David R. Soller, Adel E. Haj, Paul M. Heisig, Cheryl A. Buchwald, \\ Stephen M. Westenbroek, and James E. Reddy
}

\section{Abstract}

The glacial aquifer system, which is a collection of aquifers within Quaternary sediments in the glaciated conterminous United States, is a principal aquifer that supplies groundwater that serves about 42 million people and accounts for about 5 percent of the Nation's drinking water. This aquifer system (the area of maximum glacial advance) underlies parts of 25 States and covers $1.87 \times 10^{6}$ square kilometers. A hydrogeologic framework is presented that divides the glaciated United States into 17 distinct hydrogeologic terranes using a geologic approach based on previous mapping. Each hydrogeologic terrane contains Quaternary sediment that is derived from a common depositional history and can be characterized by similar texture and thickness. Characteristics of Quaternary sediments are described using attributes computed from a lithologic database of well logs compiled from 24 States (excluding Kentucky). The hydrogeologic framework presents a nationwide picture of the glacial aquifer system and provides generalizations concerning the nature of aquifers within it (for example, whether the aquifers are shallow or deep, and unconfined or confined). In this way insights can be gained from understanding the similarities and differences in distinct parts of the glacial aquifer system and how they relate to water use and quality and to aquifer vulnerability.

Delineation of hydrogeologic terranes was based on an interpretation of existing geologic mapping of Quaternary sediments and the thickness of unconsolidated material. Overall thickness of Quaternary sediment was used to qualitatively rank the generalized complexity of the hydrogeologic framework in each terrane: "lower" complexity (assigned a terrane code 1), "moderate" complexity (terrane code 2), and "higher" complexity (terrane code 3 ). Letter designations appended to the terrane codes (for example, 1A, 1B, or 1C) differentiate terranes of similar complexity. Two unique areas, where thick, stratified, coarse-grained sediment dominates, were assigned terrane code 4 .

Elements of this hydrogeologic framework include a glacial environments and surficial sediments geodatabase, which includes lithologic, geomorphic, and stratigraphic characterization of Quaternary sediments based on previous mapping; a gridded database of sediment and aquifer characteristics computed from lithologic logs obtained from waterwell driller records; a water-use database with information on public-water supply systems and sources of groundwater; and estimated recharge computed from a geologically based soilwater balance model. A generalized map of the bedrock geology based on previous State-level mapping is included as well.

Quaternary sediment in the glaciated United States includes glacial, postglacial (Holocene) and nonglacial sediments. At land surface, 60 percent of the glacial sediment is till. Large areas of outwash and ice contact sediments are extensive throughout the Midwest but generally are confined to valleys in the Northeast and the Northwest. Lacustrine sediments were deposited in proglacial lakes adjacent to the present Great Lakes and in glacial Lake Agassiz in the eastern Dakotas and northwestern Minnesota. The median thickness of Quaternary sediment ranges from 6 to 45 meters across the 17 hydrogeologic terranes, but the maximum thickness is more than 500 meters in some areas. Quaternary sediments generally contain less than 10 percent coarse material; the median range is near zero percent under till to about 50 percent under ice contact and outwash sediments. About 80 percent of the coarse material lies within 25 to 40 meters of land surface.

In most of the glaciated United States, there is a small likelihood of penetrating an aquifer-material interval containing coarse material at least 3 meters thick. A single aquifermaterial interval was recorded in about 44 percent of lithologic logs, whereas about 11 percent of the logs penetrated multiple intervals. About 44 percent of water wells in the lithologic database are completed in Quaternary sediment, and many of these Quaternary water wells (42 percent) are confined by at least 7.5 meters of fine materials. About 33 percent of these Quaternary water wells are unconfined - the remainder are where only thin layers (less than 3 meters) of coarse material are present. The median depths of Quaternary water wells range from 13 to 40 meters among the 17 hydrogeologic terranes.

Recharge ranges from more than 400 millimeters per year in the Northeast to 11 millimeters or less per year in the Dakotas and Montana (median value of 136 millimeters per year). Annual groundwater withdrawals compiled by county 
range on an areal basis from less than 1 to 370 millimeters per year, and the mean is 7.4 millimeters per year. About 36 percent of the withdrawals are for public-water supply, of which 70 percent are derived from Quaternary sediments. Groundwater withdrawals are less than 10 percent of recharge throughout most of the glaciated conterminous United States, but are a larger proportion of recharge near urban areas in the Northeast and the Midwest, and in counties throughout drier parts of the Midwest.

The salient characteristics of the 17 hydrogeologic terranes are presented through maps and a set of descriptive plots to facilitate visual comparisons between selected sediment and aquifer characteristics. The thickness of Quaternary sediment generally increases from the lower complexity terranes through the higher complexity terranes, consistent with their delineation. Median proportions of coarse material in Quaternary sediment and depths to aquifer-material intervals are highly variable (less than 10 to 50 percent, and 0 to 30 meters, respectively). Median thicknesses of aquifer-material intervals generally fall within a narrow range (10 to 20 meters), except in two terranes that contain thick coarse-grained sediment (30 to 35 meters). The source of water in wells varies from mostly bedrock wells in the lower complexity terranes to mostly Quaternary wells in the higher complexity terranes where the sediment is thickest. A tree diagram compiled from a hierarchical cluster analysis of a matrix composed of metrics based on sediment and aquifer characteristics, and the distribution of water wells in each terrane, indicates some groups of terranes that can be treated as comparable when analyzing groundwater flow and quality.

Aquifer-material intervals indicated on maps prepared from the lithologic logs, including unconfined and confined conditions, correlate well with aquifer systems delineated on state maps for Illinois, Indiana, and North Dakota. The large scale of the study limits the resolution at which the maps can be interpreted, however, and alluvial units are not mapped correctly for some valleys in the Northeast and the Northwest. Lithologic logs used in the study are biased toward shallow depths because not all logs penetrate the entire thickness of Quaternary sediment, but this bias should not limit the utility of the sediment and aquifer descriptions because shallow depths are commonly exploited for water supply. The hydrogeologic framework will support ongoing studies of groundwater flow and quality in the U.S. Geological Survey National Water Quality Assessment program for the glaciated United States.

\section{Introduction}

In this study the glaciated conterminous United States (fig. 1) refers to Quaternary sediment north of the line of maximum glacial advance in the conterminous United States (Booth and others, 2003; Soller and others, 2012). Quaternary sediment includes glacial, postglacial (Holocene) and nonglacial sediment. The area of maximum glacial advance underlies parts of 25 States, covers $1.87 \times 10^{6}$ square kilometers $\left(\mathrm{km}^{2}\right)$, and contains a population of about 110 million people. The groundwater resource in this area serves as a public-water supply for 43 million people; if the mixed-usage category is split equally between Quaternary sediment and bedrock, about 60 percent of these systems derive groundwater from Quaternary sediments (table 1). An estimated 42 million people are served by groundwater from Quaternary sediments in the glaciated conterminous United States, including domestic supplies (Johnson and Belitz, 2017). In 2012, the U.S. Geological Survey (USGS) began the third decade of tracking water quality in the United States. Within the program's scope of work is an assessment of the quality and vulnerability of groundwater in 20 principal aquifer systems that provide 75 percent of the Nation's groundwater used for drinking water (Rowe and others, 2013). The glacial aquifer system, defined herein as the collection of aquifers within Quaternary sediments in the glaciated conterminous United States, is included as one of these principal aquifers because groundwater withdrawals from this system account for about 5 percent of the Nation's groundwater used for drinking water (table 1; Maupin and others, 2014).

This study uses a hydrogeologic framework for use in characterizing the properties and extents of aquifers in the glaciated conterminous United States (herein referred to as the "glaciated United States") in support of the USGS objective of analyzing the status and trends in groundwater quality. In particular, this hydrogeologic framework can be used in the development of modeling tools to estimate changes in groundwater quality in areas without sampled data. Construction of the hydrogeologic framework, as described in Haj and others (2018), drew upon information provided from several previous USGS studies, including the assessment of groundwater quality conditions of Warner and Ayotte (2015), the compilation of water-well driller records of Bayless and others (2017), and mapping reports by Fullerton and Richmond (variously dated) and Soller and others $(2009,2012)$. This current effort seeks to present a comprehensive nationwide picture of the expansive and highly diverse aquifer system in the glaciated United States through a variety of maps and graphical depictions of data obtained from lithologic logs.

The hydrogeologic framework presented herein is a three-dimensional portrayal of Quaternary sediments in the glaciated United States, constructed by combining surficial mapping with depth information from lithologic logs. The hydrogeologic framework divides the glaciated United States into 17 distinct hydrogeologic terranes (fig. 1), each of which contains Quaternary sediment that is characterized by texture and thickness (Soller, 2001) and is derived from a common depositional history. A set of six maps presents glacial features referenced in discussion throughout this report (fig. 2). The hydrogeologic framework includes a glacial environments and surficial sediments geodatabase containing surficial mapping; a gridded database containing metrics describing sediment and aquifer characteristics derived from lithologic logs; a water-use database containing information on groundwater withdrawals at the source, system, and county levels; and 
B

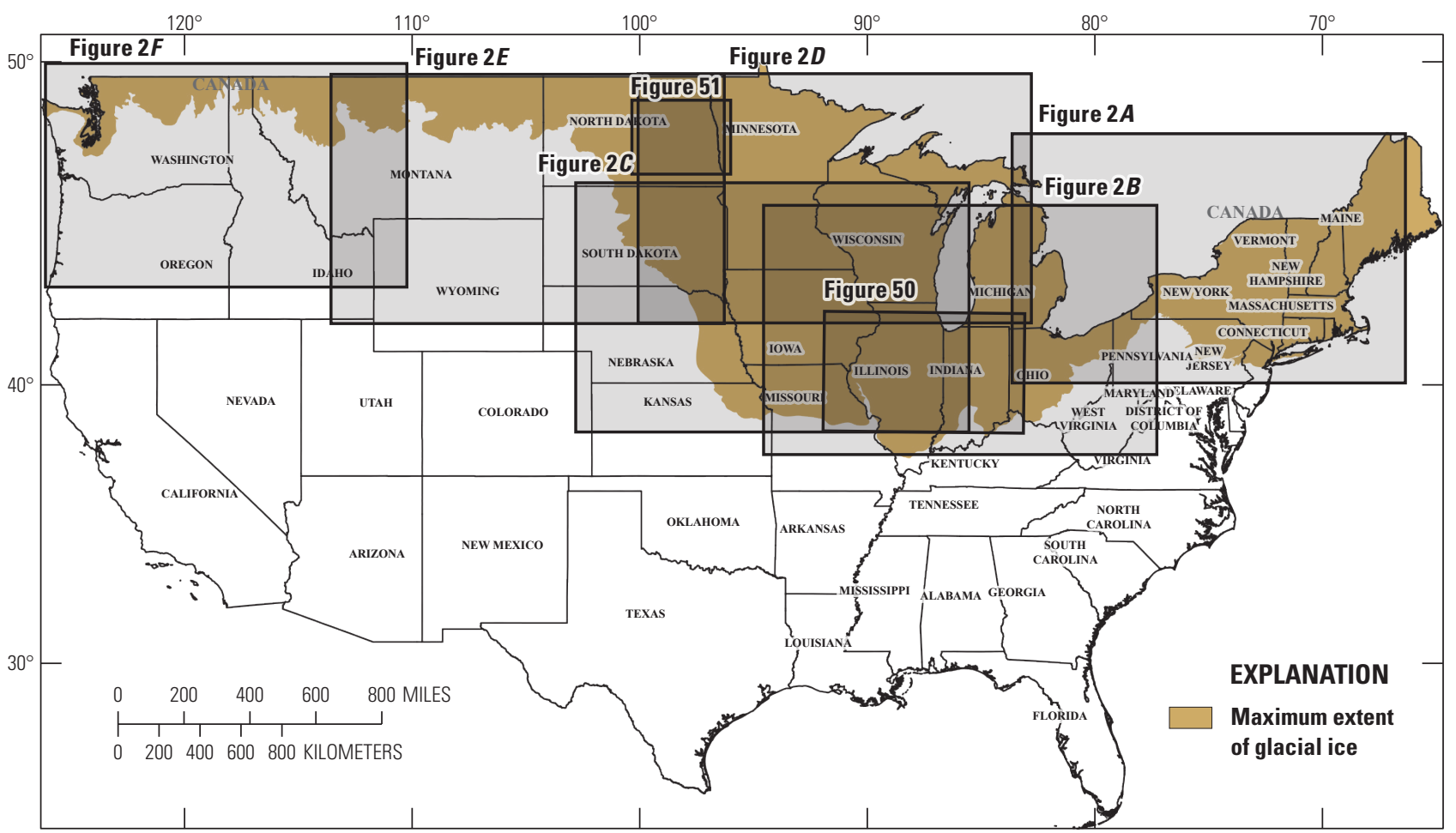

Base from U.S. Geological Survey digital data, 2018

Web Mercator Auxiliary Sphere

World Geodetic System of 1984

Figure 1. A, Hydrogeologic terranes and the maximum glacial advance in the glaciated conterminous United States; $B$, index map of study area. Map in figure $1 A$ is available at https://doi.org/10.3133/sir20185091.

a recharge database containing estimates from a geologically based soil-water balance (SWB) model. The first three products are discussed in detail in a companion data series report (Haj and others, 2018), and the fourth is described in appendix 1 .

Figure 2. Glacial features, by hydrogeologic terrane, in the glaciated United States. $A$, Terranes $1 \mathrm{~A}$ and $4 \mathrm{~A}$ in the northeastern United States; $B$, terranes $1 \mathrm{~B}, 2 \mathrm{~A}$, and $3 \mathrm{~A}$ in western Ohio, Michigan, Indiana, Illinois, eastern Wisconsin, and a small area of northern Kentucky; $C$, terranes $1 C, 2 C, 2 D, 3 C$, and $4 B$ in lowa, southern Minnesota, southeastern South Dakota, northern Missouri, eastern Nebraska and Kansas, and a small area of western Illinois; $D$, terranes 1D, 1E, 2B, and 3B in Minnesota, Wisconsin, upper Michigan, northern Illinois, and eastern North and South Dakota; $E$, terranes $1 \mathrm{~F}$ and $2 \mathrm{E}$ in North and South Dakota and in eastern Montana; and $F$, terrane $1 \mathrm{G}$ in Washington, Idaho, and western Montana. Maps are available at https://doi.org/10.3133/sir20185091.

The delineation of hydrogeologic terranes allows generalizations to be made concerning the nature of aquifers that reside within each terrane (for example, whether the aquifers are shallow or deep, and unconfined or confined).
The hydrogeologic framework also facilitates comparisons between characteristics of Quaternary sediments and aquifer properties in terranes in different parts of the glaciated United States. The nature of the terranes has important implications for the quality of groundwater within them and for the aquifer's vulnerability to contamination.

This hydrogeologic framework is not intended as, nor could it possibly be, an exhaustive and detailed study of aquifers in the glaciated United States. The inherent heterogeneity and complex distribution of Quaternary sediments, and the discontinuous nature of the glacial aquifer system itself, precludes a highly resolved portrayal of the aquifer system at a nationwide scale. As a result, this study does not provide detailed characterizations of aquifers that are commonly presented in site-specific or even regional studies. The benefits of a nationwide perspective are apparent, however, through the insights that can be gained from understanding the similarities and differences in distinct parts of the glacial aquifer system. Scientists and land-use planners working within the glaciated United States seldom have an opportunity to consider the vast expanse of the glacial aquifer system and to see how their small area fits within the greater whole.

Some important caveats apply to the generalizations made for this study. First, the nationwide scale of this study 
Table 1. Use of groundwater in the glaciated conterminous United States in 2010.

[Usage rates in million cubic meters per year $\left(\mathrm{m}^{3} / \mathrm{yr}\right) ;--$, not applicable]

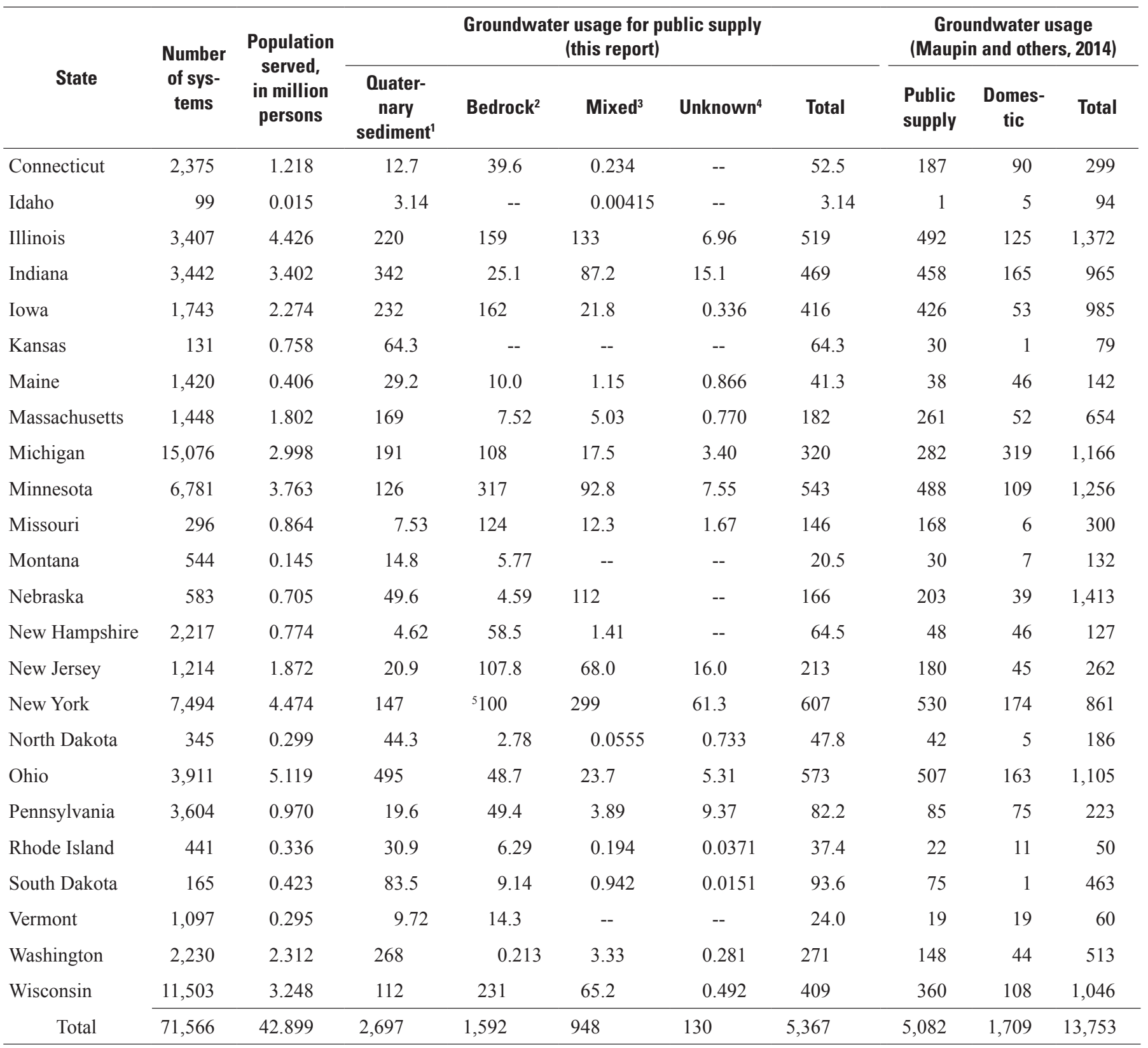

${ }^{1}$ Unconsolidated materials of Quaternary age.

${ }^{2}$ Bedrock includes of consolidated material such as sedimentary, carbonate, metamorphic, plutonic, or volcanic rock.

${ }^{3}$ Aquifer includes Quaternary sediment and bedrock.

${ }^{4}$ Aquifer could not be determined.

${ }^{5}$ Total includes 71 million $\mathrm{m}^{3} / \mathrm{yr}$ from bedrock aquifers in upstate New York and 29 million $\mathrm{m}^{3} / \mathrm{yr}$ from Cretaceous sediments on Long Island. 
limits the resolution at which the maps presented herein should be interpreted. The terrane boundaries are not precisely delineated, and the mapping presented is not intended as a means of locating aquifers or obtaining groundwater. Second, the lithologic data depicted herein were compiled from different State databases, and although an attempt was made to create standardized descriptions of the data (Bayless and others, 2017), some differences remain, resulting in noticeable shifts in aquifer properties along some state boundaries on some maps shown in this report. Also, the lithologic logs were obtained from wells that were drilled for a variety of purposes, and many wells did not fully penetrate the Quaternary sediment, for example, wells intended to obtain a water supply often are drilled to a productive aquifer, and not through the entire thickness of the Quaternary sediments. As a result, data from the lithologic logs is biased toward the upper part of the Quaternary sediments.

Finally, assumptions were made in compiling and portraying data from the lithologic logs. In particular, the term "aquifer material" as applied in this report refers to a minimum thickness of contiguous coarse material (at least 3 meters [m]) identified in lithologic logs, rather than a groundwater supply. Although this selection is arbitrary, it excludes relatively thin layers of coarse material that may not be laterally extensive; moreover, an aquifer-material interval could be either saturated or unsaturated. Water-level information was typically not available in the lithologic logs, so it was not possible to evaluate the position of the water table, nor was an attempt made to correlate stratigraphic intervals within particular areas, and thus infer hydraulic connections between adjacent logs. The hydrogeologic framework presented used for this study is intended as one depiction of mapping and data available for the glaciated United States - other portrayals with different assumptions could perhaps be demonstrated as equally valid.

\section{Purpose and Scope}

This report describes the occurrence and characteristics of confined and unconfined aquifers in Quaternary sediments in the glaciated United States using hydrogeologic terranes as delineated from geologic maps showing the texture and thickness of surficial materials and attributes of aquifer-material characteristics computed from a lithologic database that was compiled from well logs obtained from many sources. The report includes maps showing hydrogeologic terranes, surficial geology, and glacial features; groundwater use and estimated annual recharge; well density in the lithologic well database; and maps of selected aquifer-material characteristics. The report also includes descriptive statistics (box plots and bar charts) that show sediment and aquifer-material characteristics by hydrogeologic terrane. A complete description of the data sets and methodology used to compile the information presented in this report is provided in Haj and others (2018).
The hydrogeologic framework used in this report is described in Haj and others (2018) and that framework is summarized in this report for context. An additional element for the hydrogeologic framework, estimated recharge computed from a geologically based SWB model, is included in this report to facilitate the description of characteristics of confined and unconfined aquifers.

\section{Glacial History}

In the area addressed by this report, the unconsolidated sediment, Quaternary in age, is dominantly of glacial origin and is composed of considerably lesser amounts of postglacial sediment (mostly of alluvial, lacustrine, and eolian origin). A detailed description of the glacial deposits, their mode and history of deposition, is beyond the scope of this report; various articles and books on the subject introduce the deposits quite well (Flint, 1971; Sibrava and others, 1986; Gillespie and others, 2004); however, a brief description of the time intervals of Quaternary glaciation, and the relation between glacial history and the hydrogeologic terranes used herein is relevant.

\section{Geologic Time}

The beginning of the Quaternary Period is defined as the onset of a cooling climate (estimated to be 2.58 million years ago), that led to the extensive glaciations that characterize this Period. Through much of the Quaternary Period, as much as roughly 425,000 years before present (yBP), numerous glaciations occurred; in the United States this interval of time is referred to as the pre-Illinoian. The generalized ages noted in this report are from Hansel and McKay (2010); in a given region or location, specific ages may differ somewhat from those. The glacial deposits of the pre-Illinoian are not as well documented and understood as those of more recent glaciations, because much of the sediment was reincorporated into the deposits of successive glaciations; however, large areas of these materials are preserved, most notably in the southwestern part of the Midwest (for example, terranes 1C and 2D; fig. $2 C$ ).

The pre-Illinoian glaciations were followed by an interval of relative warmth, the Yarmouth interglacial episode (roughly 425,000 to $180,000 \mathrm{yBP}$ ). At roughly $180,000 \mathrm{yBP}$, glaciation of large areas of North America resumed. This episode, named the Illinoian, continued until roughly 125,000 yBP. These glacial deposits are preserved beneath vast areas of the glaciated United States, mostly in the Midwest. They are widely exposed at land surface in terranes $1 \mathrm{~B}$ and 2D (figs. 2B,C). The Illinoian glacial episode waned, and warmer climate (the Sangamon interglacial episode) dominated until about 75,000 yBP. During warm climate intervals, weathering of the glacial deposits was significant; this somewhat altered the texture and other sediment characteristics, thereby affecting water influx and recharge to underlying aquifers. 
The most recent glaciation, named the Wisconsinan glacial episode, began at about 75,000 yBP. There were two main glaciations in this time interval-Early and Late Wisconsinan glaciation. The latter was most prominent in intensity and extent, and covers the landscape in many terranes. In the United States, Late Wisconsinan glaciation was between about 25,000 and 11,000 yBP, when the glaciers receded into Canada (Dyke, 2004, provides an informative sequence of maps that show this process of deglaciation). Since that time, Quaternary sedimentary processes have been nonglacial in origin, depositing alluvial, lacustrine, and eolian deposits that are extensive in places.

\section{Ice Sheets}

Most glacial deposits in the United States are the product of the Laurentide ice sheet. At its maximum extent, the Laurentide ice sheet covered most of Canada and the northern United States, roughly 13.4 million square kilometers, with ice estimated as much as 3 kilometers $(\mathrm{km})$ in thickness. Within this ice sheet, there were two major centers of ice accumulation - in relation to present-day Hudson Bay, these lay to the east (named the Labrador center) and to the west (Keewatin center). During the latest glaciation (Late Wisconsinan time) and likely earlier as well, ice from the Labrador center was responsible for most glaciation in the United States. Deposits from the Labrador center are throughout New England and westward across the Midwest, where they abut deposits derived from ice of the Keewatin center. The boundary between these major lobes shifted within each glacial advance (such as in the Late Wisconsinan) and over the larger expanse of time that includes all the previous ice advances during the Quaternary Period. To generalize, that boundary in Late Wisconsinan time is roughly approximated by the position of the Mississippi River.

Where the two Laurentide ice centers converged in Minnesota (in hydrogeologic terrane 3B, fig. 2D), the glacial deposits are especially thick and the stratigraphy is complex. Other areas of notably thick and complex accumulations of sediment mark the convergence between adjacent lobes of ice flowing from the Keewatin and Labrador centers. An example from the Keewatin center is the Prairie Coteau (terrane 3C, fig. 2C), which formed between the southward flowing James and Des Moines lobes. Examples from the Labrador center are most prominent near the Great Lakes; for example, the northwestern part of Michigan's southern peninsula, where interaction of ice lobes flowing through the Lake Michigan trough and through Saginaw Bay formed a thick accumulation of sediment (in terrane $3 \mathrm{~A}$, fig. $2 B$ ); the Bayfield peninsula in northern Wisconsin, between sublobes flowing down the Lake Superior trough (in terrane 2B, fig. 2D); and a northeast-trending ridge lying west of Detroit, Michigan, where ice flowing down Saginaw Bay and in the Lake Erie trough converged (in terrane $3 \mathrm{~A}$, fig. $2 B$ ).

To the west of the Laurentide ice sheet, glaciers formed in the mountains of the Cordillera and coalesced into an ice sheet. This Cordilleran ice sheet extended into the United States only in the northernmost areas of western Montana, Idaho, and Washington (terrane $1 \mathrm{G}$, fig. $2 F$ ); including the area occupied in Canada, about 1.6 million square kilometers was at one time covered by it. The Cordilleran ice sheet advanced several times into the northwestern United States, and Quaternary sediments include glacial, inter-glacial, and postglacial (Holocene) deposits. The most recent glacial advance is split into three primary areas: the Purcell Trench lobe in Idaho and Montana, the Okanogan and Columbia lobes in central Washington, and the Puget lobe in the Puget Sound lowland (fig. 2F). Alpine glaciers in the Cascades and Rocky Mountains also contributed glacial sediment to lowland areas.

The Purcell Trench lobe penetrated through intermontane valleys created by Basin and Range tectonics (Clark and Kendy, 1992). Quaternary sediment is constrained mainly to these valleys and is underlain by Tertiary sediment as much as $5 \mathrm{~km}$ thick. Glacial Lake Missoula was formed at the southern limit of glaciation and periodically drained catastrophically when the ice dam at the southern end of the Purcell Trench was breached (Kahle and others, 2005). The Columbia and Okanogan lobes advanced through the Okanogan Highlands, and Quaternary sediment is constrained to valleys within the Columbia River drainage (fig. $2 F$ ). The Channeled Scablands in east-central Washington south of these lobes were eroded by catastrophic floods from the drainage of Glacial Lake Missoula. The Puget lobe advanced into a forearc basin that overlies a subduction zone in the Puget Sound lowland (Vaccaro and others, 1998).

\section{Quaternary Sediments}

Quaternary glacial sediments are deposited in many environments, either directly or indirectly associated with glacial ice. Glacial till is sediment deposited in direct contact with glacial ice: typically, it is a heterogeneous mixture of clay, silt, sand, gravel, and boulders that is unsorted and unstratified. Landforms underlain by glacial till commonly have been referred to as moraines and are named for their relative position with respect to the ice sheet; for example, an "end moraine" is the hummocky, relatively high ground where till accumulated at the terminus of a glacier that was not advancing or retreating for some period of time. "Ground moraine" is the relatively flat, low ground where till accumulated beneath the ice as the glacier moved across the landscape. On many maps and in many classifications, the lithologic and genetic term "till" is used synonymously with the geomorphic term "moraine;" this is the case with the principal source map for this publication (Fullerton and others, 2003).

In contrast to till, sediments deposited by glacial meltwater generally tend to be well-sorted and stratified. These sediments may be derived directly from glacial ice as icecontact sediments (forming geomorphic features such as kames) or indirectly from the glacial ice as lacustrine sediments deposited in proglacial lakes or as outwash sediments 
deposited by fluvial systems that originated as meltwater from the glacial ice. Alternating glacial and interglacial cycles during the Quaternary Period, and the associated advance and retreat of glacial ice, produced a complex sequence of Quaternary sediments at depth in many places. Although outwash and lacustrine sediments may be deposited at land surface, they also may be preserved at depth, and buried by successive till deposits. Aquifers commonly are in these buried meltwater sediments.

Glacial sediments may also be transported by winds along the glacial margin and deposited elsewhere. These eolian sediments tend to be sand-sized and form dunes and sand sheets on the landscape, or are silt-sized, and deposited as thick mantles of "loess." These sediments, where present, can either serve as aquifers or control infiltration and recharge into underlying aquifers.

Quaternary sediments in the glaciated United States also include nonglacial sediments. Although these sediments are not deposited by glaciers, they are often associated with glacial depositional environments and composed of reworked glacial sediments. For this study nonglacial sediments include alluvial sediments (sediments deposited by streams), marine sediments (stratified deposits along coastlines), organic sediments (peats and organic-rich sediments associated with swamps and marshes), colluvial sediments and solifluction sediments (derived from mass-wasting), and residual soils (formed from the weathering of bedrock). Colluvial sediments and residual soils generally are associated with the southern limit of glaciation, the unglaciated areas, or in the mountainous areas of the Northeast and the Northwest.

A simplified categorization system for glacial sediments from Fullerton and Richmond (variously dated) was used in this study to group mapped lithology into 1 of 12 sedimentological categories and 1 bedrock category (map units; table 2). A more detailed explanation regarding the grouping of these units is in Haj and others (2018). Glacial sediments considered as stratified in this study include alluvial, eolian, lacustrine, outwash, and ice-contact sediments.

\section{Aquifers in Quaternary Sediments}

Aquifers in Quaternary sediments are present in coarsegrained materials (mostly sand and gravel) that are extensive and thick enough to provide a reliable water supply for a home, farm, business, or community. High-yielding aquifers that support public water supply typically are more extensive and thicker than low-yielding aquifers that can only support domestic water supply. Although the primary characteristics of these aquifers are their extent and thickness, they also can be characterized by the nature of their connections with the hydrologic cycle at land surface. This hydraulic connection is controlled by the degree of confinement of the aquifer: the extent to which the coarse-grained materials are overlain by fine-grained materials (mostly silt and clay) that limit infiltration of water from land surface (fig. 3). Unconfined aquifers are exposed at land surface or are shallow and overlain by thin deposits of fine-grained materials, so that precipitation can readily infiltrate to the aquifer as recharge. In contrast, confined aquifers are usually deep and overlain by thick deposits of fine-grained materials that limit or prevent infiltration of water from land surface. Many aquifers are partially overlain by fine-grained materials and are referred to as semiconfined, because part of the aquifer extent is unconfined whereas the remainder is confined.

Table 2. Principal map unit categories and descriptions included in the hydrogeologic framework of the glaciated conterminous United States.

[--, not applicable]

\begin{tabular}{lll}
\hline \multicolumn{1}{c}{ Map unit } & \multicolumn{1}{c}{$\begin{array}{c}\text { Fullerton and Richmond } \\
\text { (variously dated) }\end{array}$} & \multicolumn{1}{c}{$\begin{array}{c}\text { Soller and others } \\
\text { (2009) }\end{array}$} \\
\hline Alluvial sediment & Alluvial and sheetwash & Alluvial. \\
\hline Bedrock & Bedrock & Volcanic, basaltic, and andesitic rocks. \\
\hline Colluvial sediment & Colluvium and landslide & Colluvial. \\
\hline Eolian sediment & Eolian, loess, beach and dune sand & Eolian. \\
\hline Fill & Fill and manmade land & -- \\
\hline Ice-contact sediment & Ice-contact and kame & Glaciofluvial ice-contact. \\
\hline Lacustrine sediment & Lake & Proglacial, fine grained. \\
\hline Marine sediment & Marine & Coastal zone. \\
\hline Organic sediment & Peat, muck, swamp and marsh & Organic-rich muck and peat. \\
\hline Outwash sediment & Outwash & Proglacial, coarse-grained. \\
\hline Residual soil & Decomposition, residuum, and grus & Residual. \\
\hline Solifluction sediment & Solifluction & -- \\
\hline Till & Till and ice-thrust & Glacial till. \\
\hline
\end{tabular}




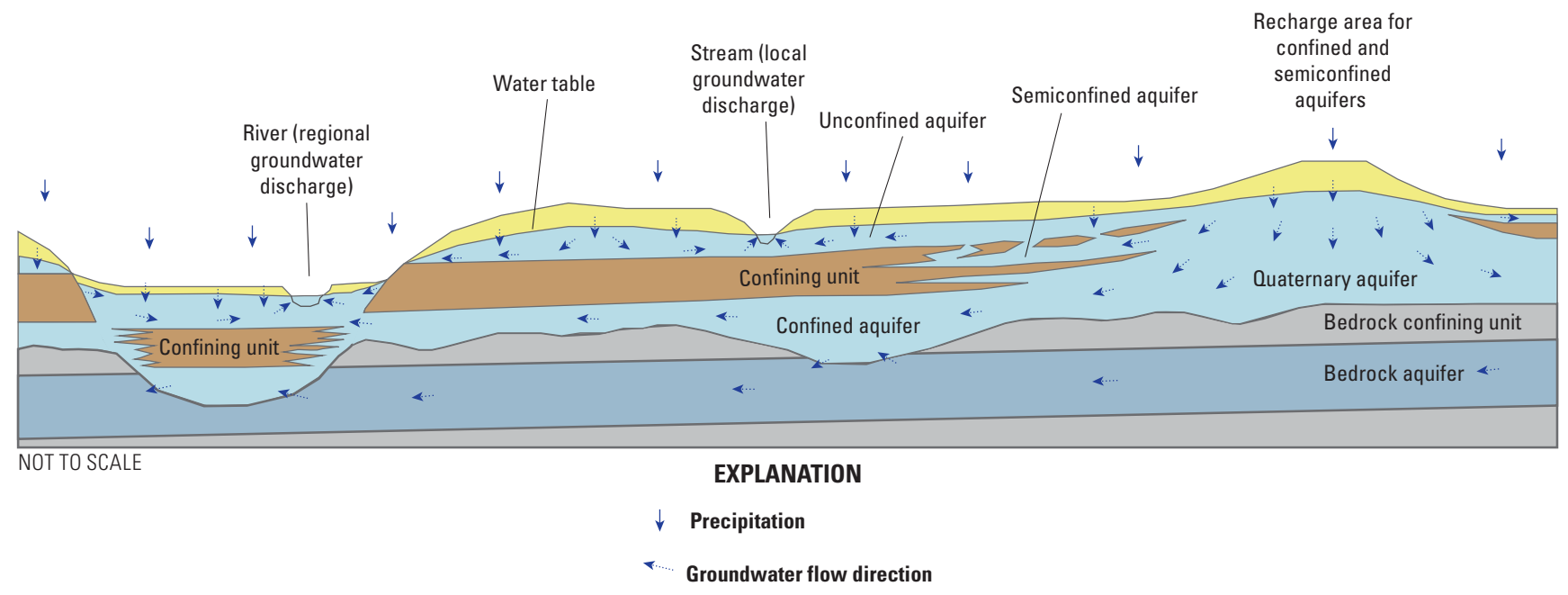

Figure 3. Examples of unconfined, semiconfined, and confined aquifers Quaternary sediments.

The degree of confinement also determines the recharge and discharge areas associated with the aquifer. Unconfined aquifers generally accept recharge from land surface over their entire extent (fig. 3), whereas recharge to confined and semiconfined aquifers is limited to areas where permeable materials hydraulically connect the aquifers to land surface or to overlying aquifers. Similarly, unconfined aquifers discharge to perennial streams wherever they are incised into the coarse-grained materials. Confined and semiconfined aquifers generally are not connected to overlying streams, and only discharge to streams that cut deeply through the overlying fine-grained materials, or that drain the unconfined part of the aquifer. Principal discharge areas associated with confined and semiconfined aquifers are typically at some distance from the recharge area of the aquifer.

Mapping the extents of unconfined aquifers typically can be done by inspecting surficial geologic maps that identify landforms underlain by coarse-grained material such as those in outwash and ice-contact deposits. Some of these features are unsaturated, however, and knowledge concerning the elevation of the water table also is required to identify aquifers. The thickness of unconfined aquifers can be estimated through well borings, although more complete descriptions of aquifer geometry can require detailed study, such as geophysical surveys and test drilling. Mapping the extents of confined aquifers is much more difficult because surface mapping does not reveal much information concerning the subsurface. Thick glacial sediment is often highly heterogeneous, and thus coarse-grained materials in one location may not be hydraulically connected to other coarse-grained materials nearby. Hydraulic testing between wells, geochemical sampling, or both are required to adequately map the connections within confined aquifers, and although well borings can provide estimates of aquifer depth and thickness, the exact geometry of a confined aquifer is often unknown.
Quaternary aquifers that extend to the bedrock surface also can be hydraulically connected to bedrock aquifers (fig. 3). Groundwater flows from a Quaternary aquifer to a bedrock aquifer where groundwater levels in the Quaternary aquifer are higher than groundwater levels in the bedrock aquifer, and vice versa. Discharge of bedrock water into Quaternary aquifers can affect groundwater chemistry in areas where bedrock water differs in chemistry from groundwater in Quaternary aquifers.

\section{Vulnerability of Quaternary Aquifers to Contamination}

The likelihood of groundwater contamination in Quaternary aquifers can be assessed by the intrinsic susceptibility and the vulnerability of the aquifer (Focazio and others, 2002). Intrinsic susceptibility refers to the physical aquifer characteristics that determine its hydraulic connection to the hydrologic cycle and the rate of groundwater flow through the aquifer. Vulnerability depends on the intrinsic susceptibility of the aquifer, as well as the proximity of potential contaminants and the dominant geochemical processes that control contaminant fate and transport. The degree of confinement of an aquifer, therefore, largely determines its vulnerability to anthropogenic and natural contaminants.

Groundwater in unconfined aquifers is relatively young; residence times generally are less than a few decades (Warner and Ayotte, 2015). For example, 51 of 66 public-supply wells sampled from unconfined aquifers in the glaciated United States contained relatively young (post-1953) water, with a median estimated mean groundwater age of 18 years (Bryant Jurgens, U.S. Geological Survey, written commun., 2018). Recharge and anthropogenic contaminants can, therefore, infiltrate relatively quickly into unconfined aquifers. As a result, groundwater in unconfined aquifers generally is an oxic (aerobic) geochemical 
environment (Warner and Ayotte, 2015). In contrast, groundwater in confined aquifers is relatively old; residence times range from decades to hundreds of years or more. For example, 39 of 49 public-supply wells sampled from confined aquifers in the glaciated United States contained relatively old (pre-1953) water, or mixtures of pre- and post-1953 water, with a median estimated mean groundwater age of 2,600 years (Bryant Jurgens, U.S. Geological Survey, written commun., 2018). Confined aquifers are less well connected to the hydrologic cycle through recharge than unconfined aquifers, so anthropogenic contaminants are less of a concern, unless there is substantial groundwater withdrawal from the aquifer. Groundwater in confined aquifers progressively loses oxygen with residence time through bacterial action and interaction with organic material, eventually creating a reduced (anoxic) geochemical environment (Warner and Ayotte, 2015). As a result, natural contaminants such as arsenic are more of a concern than in unconfined aquifers.

\section{Glaciated United States}

In this study the glaciated United States (fig. 1) refers to the area north of the line of maximum glacial advance in the conterminous United States. A previous study of groundwater quality divided this area into five regions on the basis of hydrochemical facies grouped by similarities in the composition of inorganic constituents that dominate the groundwater chemistry (Arnold and others, 2008). The hydrochemical facies were classified using a cluster analysis of concentration data for 8 major and minor ions collected from 1,713 wells completed in Quaternary sediments. The five hydrochemical regions reflect environmental characteristics that determine how much water can enter the groundwater system, and how long the water remains in contact with soil and rock materials. These characteristics include climate, soil texture, vegetation and land use. The regions are described as the Midwestern agricultural region, the Northern and Great Lakes Forested region, the Western agriculture and grassland region, the Mountain and coastal forested region, and the urban-influenced region (fig. 4).

Figure 4. Hydrochemical regions in the glaciated conterminous United States; regions delineated by Arnold and others (2008) from a statistical analysis of water-quality data. Map is available at https://doi.org/10.3133/sir20185091.

The current study used a geologically based approach to divide the glaciated United States into 17 hydrogeologic terranes based on sediment thickness and texture, and the age and mode of glacial deposition. The terrane delineation is based on an interpretation of existing geologic mapping of Quaternary deposits (Soller and others, 2009; Fullerton and Richmond, variously dated), and thickness of unconsolidated material (Soller and others, 2012). Characteristics of aquifers in these materials are described using attributes that were computed from a lithologic database of well logs compiled from 24 States (excluding Kentucky, where only a small strip of land is glaciated) within the glaciated United States (Bayless and others, 2017). Aquifer characteristics are presented by terrane to contrast differences in the types of aquifers that are in distinct parts of the glaciated United States, and are mapped to provide a generalized spatial representation of these characteristics across the glacial aquifer system. The delineated terranes and mapping provides an additional perspective on the hydrogeologic framework to facilitate ongoing studies (Rowe and others, 2013) interpreting water-quality data from wells tapping Quaternary aquifers in the glaciated United States.

\section{Data Sources}

Elements of the hydrogeologic framework include a glacial environments and surficial sediments geodatabase, which includes lithologic, geomorphic, and stratigraphic characterization of Quaternary sediments and bedrock geology based on previous mapping; a gridded database of sediment and aquifer characteristics computed from lithologic logs obtained from water-well driller records; a water-use database with information on public-water supply systems and sources of groundwater; and estimated recharge computed from a geologically based SWB model. Data sources used to construct these elements are described in this section.

\section{Hydrogeologic Terranes}

The composition of Quaternary sediments to a large extent controls the occurrence and geometry of aquifers, and whether or not they might provide a useable supply of groundwater. The lithology and stratigraphy of geologic materials at land surface is understood and mapped relatively well, at least in a regional sense. In comparison, the nature of these sediments in the subsurface, at a level of detail sufficient to delineate individual aquifers, is understood more poorly. The reasons for this include the high cost of obtaining subsurface information, and the difficulty in predicting the geometry and variations in lithology of buried geologic units. Predictability is especially difficult for terrestrial depositional settings such as the glaciated areas, given the nature of glaciofluvial processes and the numerous glaciations to which large areas of the United States have been subjected. It is logical, therefore, to adopt a generalized approach to characterizing and classifying the glacial hydrogeologic framework of the United States to provide a regional tool for describing the aquifers in the region and the potential vulnerability to contamination of aquifers at depth.

For the glaciated United States, this study used existing mapping and knowledge of the regional geologic framework as the foundation for a generalized classification of these sediments. This classification was designed to address the potential for penetrating coarse-grained sediments (for example, sand and gravel) that might, given an adequate influx of water, serve as aquifers. Given our emphasis on the potential for penetrating 
aquifers in these materials, we refer to the various regions delineated by this classification as "hydrogeologic terranes."

These hydrogeologic terranes (fig. 1) were defined on the basis of the following criteria:

- overall thickness of Quaternary-age sediment (Haj and others, 2018, fig. 8), on the basis of the assumption that the greater the thickness, the higher the likelihood of penetrating aquifers in the subsurface,

- the predominant texture of the geologic materials at land surface (Soller, 2001),

- the predominant modes of glacial deposition (for example, ice advance that was mostly unconstrained by other glacial lobes, inter-morainal regions between major ice lobes, and so forth), and

- the age of deposition (included as a criterion because of the general observation that deposits of the latest glaciation [Late Wisconsinan] may differ from older glacial deposits in terms of their weathering characteristics).

The first of those criteria (overall thickness of Quaternary-age sediment) was used to qualitatively rank the complexity of the geologic framework in each hydrogeologic terrane. These rankings are highly generalized, used only to give the reader a sense of the relative potential for penetrating confined aquifers. Because of the nature of deposition in glaciated areas, all of the area can be expected to be highly heterogeneous even at the local scale of less than $1 \mathrm{~km}$. The values are "lower" complexity (terrane code $=1$ ), "moderate" complexity (terrane code $=2$ ), and "higher" complexity (terrane code $=3$ ). To differentiate the various terranes of similar, general complexity, letter designations were appended to the numeric codes; for example, terranes 1A, 1B, and 1C are geographically separate areas, all with a complexity code of 1 (fig. 2). There are two rather unique areas, where thick, stratified, coarse-grained sediment dominates; these areas were assigned terrane code $=4$ to differentiate them from the other terranes, which are composed mostly of till.

Any classification should be used with caution and understanding of the caveats. This is especially true for highly generalized, regional ones such as these hydrogeologic terranes. Here are the two principal caveats:

Variability within a hydrogeologic terrane.-To achieve a manageable number of elements in this classification, substantial hydrogeologic variations within a delineated terrane are acknowledged. These variations are commonly indicated by well logs whose profiles do not match the generalized description for the terrane.

Similarity between hydrogeologic terranes, especially near the boundaries. - Certain terrane boundaries are based on well-delineated geologic criteria (for example, the limit of Late Wisconsinan ice). Many other boundaries are positioned less precisely on the basis of regional changes in overall thickness of Quaternary sediment or along regional trends of end moraines. In certain cases, the boundaries were arbitrarily drawn, using major rivers as boundaries. The terrane boundaries therefore should be considered as "fuzzy" in nature, positioned in a very general sense, with considerable similarities in the geologic framework near the boundary on both sides.

\section{Surficial Geology}

Map units based on the depositional environment, sediment texture and character, and geomorphic expression of the surficial sediments in this hydrogeologic framework are taken from two published mapping reports: the USGS Quaternary Atlas Series (Fullerton and Richmond, variously dated) and the Surficial Materials Map of Soller and others (2009). Fullerton and Richmond (variously dated) covers the eastern glaciated United States east of the 108th meridian (with the exception of one quadrangle that overlaps slightly with the western edge of the glaciated United States) at a 1:1,000,000 scale; Soller and others (2009) covers the United States at a 1:5,000,000 scale - the northwestern part of the glaciated United States not covered by Fullerton and Richmond (variously dated) was based on this map.

The principal map units in table 2 from Fullerton and Richmond (variously dated) and Soller and others (2009) are delineated in the Glacial Environments and Surficial Sediments (GESS) geodatabase of Haj and others (2018). The surficial map units (fig. 5) use a consistent terminology, and contain additional attributes that include a six-bin texture classification ranging from mostly clayey to mostly sandy, and including organic material (fig. 6); stratified surficial sediments (fig. 7); and subclassifications of till, including ground moraine, end moraine (shown on fig. 5) and stagnation moraine.

Figure 5. Glacial Environment and Surficial Sediments (GESS) geodatabase map units (GESS_MU attribute) in the glaciated conterminous United States; surficial geology from Haj and others (2018). Map is available at https://doi.org/10.3133/sir20185091.

Figure 6. Textural classification of Glacial Environment and Surficial Sediments geodatabase map units in the glaciated conterminous United States. Map is available at https://doi. org/10.3133/sir20185091.

Figure 7. Generalized bedrock lithology (modified from the Integrated Geologic Map Databases for the United States) and overlying Glacial Environment and Surficial Sediments geodatabase coarse-grained, stratified surficial sediments in the glaciated conterminous United States; surficial geology from Haj and others (2018). Map is available at https://doi.org/10.3133/ sir20185091.

\section{Bedrock Geology}

A generalized map of the bedrock geology underlying the glaciated United States has been compiled from state geologic 
maps (USGS, obtained from https://mrdata.usgs.gov/geology/ state/). A map (fig. 7) is provided for geologic context, and to indicate both the local provenance of glacial sediment and where shallow Quaternary aquifers could be in contact with bedrock aquifers. The coarse-grained stratified sediments depicted on the map are defined in Haj and others (2018, table 2).

Most of the Midwest is underlain by clastic or carbonate sedimentary bedrock, with the exception of northern Minnesota, Michigan, and Wisconsin, which are underlain by metamorphic, plutonic or volcanic (crystalline) bedrock. Much of the Northeast, with the exception of western and southern New York, also is underlain by crystalline bedrock. Some of the areas denoted as carbonate in the Northeast (for example in Vermont) have been metamorphosed to marble. As a result, these areas probably do not contain a water-bearing bedrock-fracture system that is characteristic of unmetamorphosed carbonate rock.

Quaternary sediments in two areas within the glaciated United States are underlain by unconsolidated sediment not derived from glaciation. Long Island, New York, the northern part of which lies within the glaciated United States, is underlain by older sediments that are part of the North Atlantic Coastal Plain aquifer system (Masterson and others, 2013). The Quaternary sediment in many of the valleys in the Northwest and smaller parts of the remainder of the glaciated United States (for example, Nebraska) are either underlain by nonglacial, unconsolidated sediments or the type of underlying bedrock has not been mapped.

\section{Lithologic Database}

A lithologic database for the glaciated United States was compiled from State well records, and the well logs were standardized so that the lithologic information used a consistent terminology (Bayless and others, 2017). The part of the database used for this study is described in Haj and others (2018), and contains 1,565,349 lithologic logs, of which 740,727 are from water wells (table 3 ). The data density varies with about 14 percent of the well records in the Northeast (terranes 1A and 4A), about 2 percent in the Northwest (terrane 1G) and the remaining 84 percent in the Midwest (fig. 8; table 4). Five Midwestern States account for more than 70 percent of the data: Illinois, Michigan, Minnesota, Ohio, and Wisconsin. Little information is available concerning Quaternary sediment in lithologic logs in Maine, so plots and maps of sediment and aquifer-material characteristics do not include data from Maine. Most of the lithologic logs for water wells in the database are for domestic wells. Three States (Connecticut, Michigan, and Nebraska) do not record the usage of wells associated with the logs, so no information is available regarding the distribution of water wells.

Figure 8. Density of lithologic logs aggregated on a 5-kilometer grid in the glaciated conterminous United States. Map is available at https://doi.org/10.3133/sir20185091.
Table 3. Lithologic logs and water wells, by State, in the glaciated conterminous United States.

[Data are from Haj and others (2018); --, no data]

\begin{tabular}{|c|c|c|c|}
\hline \multirow[b]{2}{*}{ State } & \multirow[b]{2}{*}{ Lithologic logs } & \multicolumn{2}{|c|}{ Water wells } \\
\hline & & Bedrock & $\begin{array}{c}\text { Quaternary } \\
\text { sediment }\end{array}$ \\
\hline Connecticut & 15,451 & -- & -- \\
\hline Idaho & 607 & 444 & 153 \\
\hline Illinois & 197,094 & 88,216 & 73,808 \\
\hline Indiana & 116,543 & 36,097 & 63,188 \\
\hline Iowa & 32,174 & 9,009 & 3,506 \\
\hline Kansas & 1,982 & 1,442 & 207 \\
\hline Maine & 42,239 & 40,873 & 172 \\
\hline Massachusetts & 9,926 & 5,005 & 1,487 \\
\hline Michigan & 283,054 & -- & -- \\
\hline Minnesota & 189,324 & 54,425 & 113,419 \\
\hline Missouri & 10,154 & 7,485 & 1,004 \\
\hline Montana & 29,283 & 6,781 & 15,519 \\
\hline Nebraska & 32,041 & -- & -- \\
\hline New Hampshire & 4,892 & 3,896 & 244 \\
\hline New Jersey & 339 & 316 & 16 \\
\hline New York & 11,405 & 9,747 & 810 \\
\hline North Dakota & 18,798 & 341 & 2,060 \\
\hline Ohio & 125,358 & 35,085 & 10,732 \\
\hline Pennsylvania & 12,517 & 7,742 & 1,097 \\
\hline Rhode Island & 577 & 488 & 1 \\
\hline South Dakota & 27,471 & 276 & 190 \\
\hline Vermont & 67,484 & 64,881 & 12 \\
\hline Washington & 4,810 & 1,723 & 2,285 \\
\hline Wisconsin & 331,826 & 42,173 & 34,238 \\
\hline Total & $1,565,349$ & 417,361 & 323,366 \\
\hline
\end{tabular}

Several metrics that characterize the Quaternary sediment and aquifer materials penetrated by the wells were computed from the lithologic logs (fig. 9A; table 5). The Quaternary sediment thickness was computed if the depth to bedrock was noted in the lithologic log. Where the log did not report bedrock, the thickness was estimated from available maps of the Quaternary sediment thickness. For the area east of the 108th meridian, the map of Soller and Garrity (2018) was used to estimate depth to bedrock. In the Northwest, the map of Jones (1999) was used in the Puget Sound area, and a map from Ely and Kahle (2004) was used in a small area near Colville, Washington. No maps of Quaternary sediment thickness were available for areas of eastern Washington, Idaho, and Western Montana.

For the purpose of computations, the sediment was classified into fine (clay and silt) and coarse (fine sand to gravel) categories. Potential aquifer material was considered to be $3 \mathrm{~m}$ 
Table 4. Lithologic logs, by hydrogeologic terrane, in the glaciated conterminous United States.

[Data are from Haj and others (2018); $\mathrm{km}^{2}$, square kilometer]

\begin{tabular}{crrrrc}
\hline \multirow{2}{*}{$\begin{array}{c}\text { Hydrogeologic } \\
\text { terrane }\end{array}$} & $\begin{array}{c}\text { Area, } \\
\mathbf{k m}^{2}\end{array}$ & $\begin{array}{c}\text { Percent of glaciated } \\
\text { conterminous } \\
\text { United States }\end{array}$ & Total & $\begin{array}{c}\text { Percent extending } \\
\text { to bedrock }\end{array}$ & $\begin{array}{c}\text { Mean penetration of } \\
\text { Quaternary sediment, } \\
\text { in percent }\end{array}$ \\
\cline { 6 - 6 } & 350,536 & 18.8 & 208,603 & 90.8 & 97.4 \\
1A & 108,773 & 5.8 & 79,387 & 52.0 & 87.7 \\
1B & 64,200 & 3.4 & 11,167 & 86.0 & 97.6 \\
1C & 88,260 & 4.7 & 136,832 & 69.3 & 91.5 \\
1D & 72,275 & 3.9 & 32,789 & 42.9 & 90.3 \\
1E & 147,728 & 7.9 & 13,701 & 39.5 & 82.7 \\
1F & 100,095 & 5.4 & 24,869 & 30.4 & 94.2 \\
1G & 218,790 & 11.7 & 477,636 & 53.4 & 82.6 \\
2A & 76,625 & 4.1 & 125,280 & 22.0 & 74.6 \\
2B & 47,415 & 2.5 & 14,453 & 56.6 & 78.8 \\
2C & 135,879 & 7.3 & 39,949 & 55.5 & 79.7 \\
2D & 155,029 & 8.3 & 28,860 & 37.2 & 68.9 \\
2E & 74,518 & 4.0 & 195,289 & 2.3 & 33.0 \\
3A & 153,051 & 8.2 & 145,742 & 25.3 & 64.0 \\
3B & 58,019 & 3.1 & 15,538 & 18.7 & 39.9 \\
3C & 3,158 & 0.2 & 1,760 & 3.6 & 42.4 \\
4A & 12,037 & 0.6 & 13,196 & 13.9 & 71.2 \\
4B & & & & & \\
\hline
\end{tabular}

or more of contiguous coarse material within a lithologic log that could include layers of fine materials as much as $1.5 \mathrm{~m}$ thick. Water wells were classified as Quaternary wells (class 1) or bedrock wells (classes 3 to 5) based on the screened interval, or based on the well depth and the thickness of Quaternary sediment (fig. 9B) for the 25 percent of water wells for which screened intervals were not available. A separate class of water wells, termed "top-of-rock" (class 2), were completed within the top $7.5 \mathrm{~m}$ of the bedrock surface. It was assumed that these wells could derive groundwater from both Quaternary and bedrock aquifers. Quaternary sediments are underlain by Tertiary sediments on Long Island and in some intermontane valleys in terrane $1 \mathrm{G}$. Water well depths on Long Island were compared to the thickness of Quaternary sediment from Soller and Garrity (2012) to classify Quaternary and Tertiary wells. All water wells completed in unconsolidated material were assumed to be Quaternary wells in terrane $1 \mathrm{G}$ where information on the thickness of Quaternary sediment is lacking.

Computed metrics pertaining to the Quaternary sediment include the coarse fraction in the total thickness and the coarse fractions in the uppermost 7.5, 15, and $30 \mathrm{~m}$ of the lithologic $\log$. Cumulative frequency plots shown in later sections of this report were developed for groups of lithologic wells (by map unit and hydrogeologic terrane) showing the proportions of coarse- and fine-grained material in 1-m depth intervals within $100 \mathrm{~m}$ of land surface. Aquifer metrics were computed for the thickest (main) aquifer-material interval in the log and the deepest (bottom) aquifer-material interval. In most water-well logs (85 percent) these intervals were identical. Screenedinterval data indicate that about 80 percent of the water wells that penetrated more than one interval were screened in the bottom aquifer-material interval; therefore, statistics in the following sections of the report are reported for the bottom aquifer-material intervals. The number of these intervals penetrated by each log also is noted.

The sediment and aquifer-material metrics are used to describe the characteristics of the glaciated United States through box plots and bar charts grouped by hydrogeologic terranes and by map unit shown in later sections of the report. For selected metrics, system-wide maps were interpolated using an approach described below in the section "Subsurface Sediment." These descriptive statistics and maps used the median value of each metric within a 1-km geospatial grid cell to deemphasize clusters in the data. Nonetheless, the high well density in some States tends to skew the descriptive statistics; for example, data from Ohio and Vermont account for 69 percent of the total number of logs while accounting for only about 12 percent of the area in terrane 1A. Aggregating the data by $1-\mathrm{km}$ grid cells reduced the Ohio and Vermont contribution to about 38 percent of the total number of cells. The gridded data used to construct the figures and maps presented in this report are available in Yager and others (2018).

Not all wells penetrated the entire thickness of Quaternary sediment, especially in areas where the sediment 

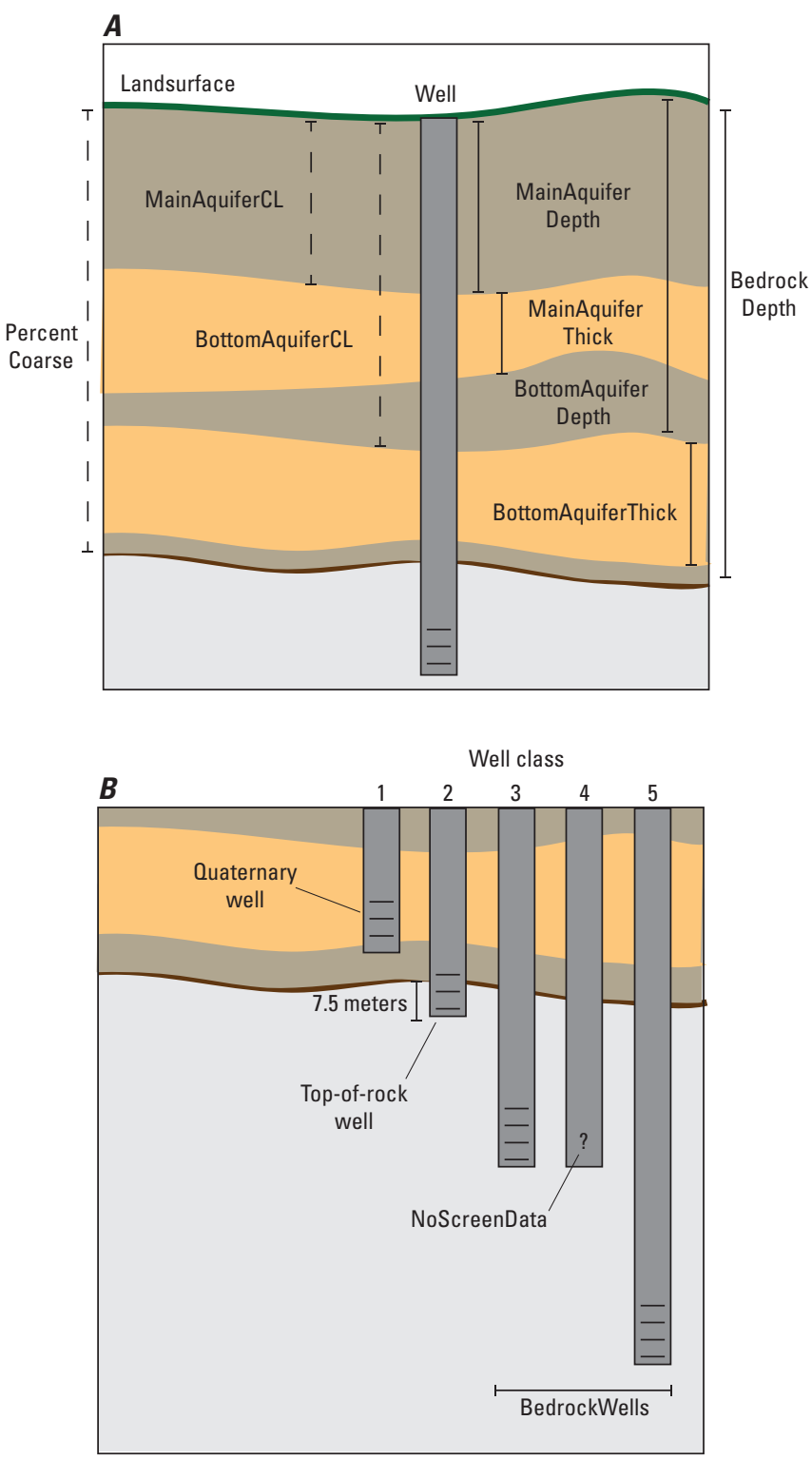

EXPLANATION

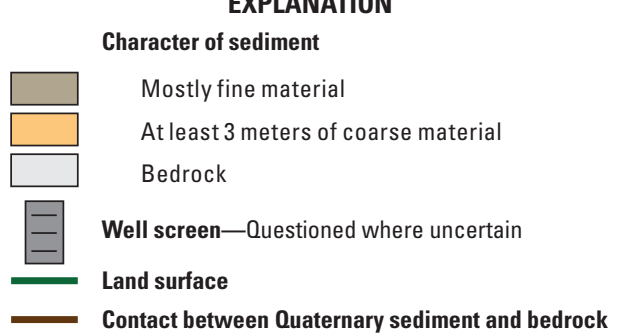

Figure 9. Variables computed from lithologic logs in the glaciated conterminous United States. $A$, Characteristics of sediment and intervals of aquifer material and $B$, classification of water wells by assumed source for aquifers (variables defined in table 5). is thickest. Most of the lithologic logs penetrate the entire thickness in terrane $1 \mathrm{~A}$, whereas on average only 41 percent of the logs offer a complete description of the sediment (table 4). In several terranes (2B, 3A, 3C, 4A, and 4B), less than 25 percent of the logs reach the bedrock surface. About 75 percent of the sediment thickness is typically characterized by lithologic logs, however, with the exception of terranes $3 \mathrm{~A}, 3 \mathrm{C}$, and $4 \mathrm{~A}$, where less than 45 percent of the average thickness was penetrated by the logs (table 4). All well logs were used to prepare descriptive statistics to extend coverage over the widest possible area, so in some areas these plots are biased toward data from shallow wells. Another important caveat to consider is that some aquifer-material intervals identified in well logs could be partially saturated, so the computed aquifer-material thickness could be greater than the useable (saturated) thickness of the aquifer material.

\section{Groundwater Usage}

Records of groundwater usage for public supply were collected for portions of 24 States within the glaciated United States (excluding Kentucky) for water systems that withdraw groundwater through wells and springs (table 1). Water-use records for the 71,566 systems inventoried include the type of public water system, the location and the population served by the system, the withdrawal rates, the well construction data, and the source aquifer of the water supply. The wateruse records were sought for the reporting years 2009 to 2013, with a target year of 2010 to compare the data to the most recent USGS national water-use compilation (USGS, 2015). The desired data for each record were typically not available from a single database. As a result, information on withdrawal rates, well construction, and aquifer source were compiled and cross-referenced from State and Federal databases. A summary of the methodology used to compile these records from State and Federal databases is provided in Haj and others (2018).

Assigning the source aquifer, either in Quaternary sediment or bedrock, for each water system is difficult because few States provide an aquifer code in their databases and well construction data are not always available. In this study, the source aquifer was assigned by comparing the well location to maps of sediment thickness (Soller and others, 2012; Soller and Garrity, 2018) or delineated aquifers from State level mapping, if well construction data from either the source well or nearby wells were not available. In the absence of these data, the source aquifer was assigned to the predominant aquifer source within each county. In cases where no predominant aquifer could be determined, the Quaternary sediment thickness map (in Soller and Garrity, 2018) was used to assign wells to either a bedrock aquifer (if the sediment thickness was less than $15 \mathrm{~m}$ ), or a Quaternary aquifer (if the sediment thickness was greater than $60 \mathrm{~m}$ ). These limits were arbitrary based on other public supply wells for which lithologic logs were available. The aquifer source could not be assigned for the remaining 10 percent of the public water-supply systems. 
Table 5. Variables used in lithologic logs in the glaciated conterminous United States.

[m, meter; km, kilometer; <, less than; >, greater than; GESS, Glacial Environment and Surficial Sediments geodatabase (Haj and others 2018); GESS_MU, GESS map unit attribute]

\begin{tabular}{|c|c|}
\hline Variable & Definition \\
\hline \multicolumn{2}{|r|}{ Well attributes } \\
\hline ID & Well identifier. \\
\hline GridID & Sequential number in $1-\mathrm{km}$ grid. \\
\hline Terrane & Hydrogeologic terrane. \\
\hline BedrockDepth & Depth of bedrock below land surface. \\
\hline BedrockDepthSource & $\begin{array}{l}\text { Source of bedrock-depth data; from log, or estimated from Jones (1999), Ely and Kahle } \\
\text { (2004), or Soller and Garrity (2018). }\end{array}$ \\
\hline PercentLogPenetration & Percent penetration of log through Quaternary sediment. \\
\hline NumberAquifers & Number aquifer-material intervals ${ }^{1}$. \\
\hline Texture4 & 4-bin texture class of GESS_MU. \\
\hline Texture6 & 6-bin texture class of GESS_MU (figure 6). \\
\hline SiteUse & Use of well associated with log. \\
\hline WellSource & Waterwell source (Haj and others, 2018, table 6). \\
\hline
\end{tabular}

\section{Percent coarse material in Quaternary sediment:}

PercentCoarse

PercentCoarse7.5

PercentCoarse 15

PercentCoarse 30

Thickest aquifer-material interval:

MainAquiferDepth

MainAquiferThick

MainAquiferCL

Deepest aquifer-material interval:

BottomAquiferDepth

BottomAquiferThick

BottomAquiferCL

Well class 1

Well class 2

Well class 3

Well class 4

Well class 5
Total thickness.

Upper $7.5 \mathrm{~m}$.

Upper $15 \mathrm{~m}$.

Upper $30 \mathrm{~m}$.

Depth.

Thickness.

Percent of coarse material in sediment (confining layer) overlying aquifer-material interval.

\footnotetext{
${ }^{1}$ Defined as contiguous interval of coarse material at least $3 \mathrm{~m}$ thick, containing less than $1.5 \mathrm{~m}$ of fine material.
} 


\section{Recharge}

The magnitude and distribution of groundwater recharge in the glaciated United States was computed using national spatial data sets and the SWB model (Westenbroek and others, 2010). The SWB model calculates spatial and temporal variations in recharge based on climatological data, and soil and landscape properties (appendix 1). The SWB model is a deterministic model that uses gridded data and physically based parameters to apportion water derived from daily rainfall and snowmelt into surface runoff, evapotranspiration, recharge, and water storage in the soil column. Recharge is computed as surplus water in excess of the soil field capacity, a product of available water capacity and root depth in the soil column.

Available water-capacity and the maximum recharge rate were assigned on the basis of the texture classes of the map units of Quaternary sediment discussed previously (fig. 5; table 1.3), and the hydrologic soil group from the State Soil Geographic (STATSGO) database (Miller and White, 1998). The rationale behind this decision was to ensure higher recharge in lowlands occupied by coarse-grained sediment (for example, alluvium and outwash) than in adjacent uplands underlain by fine-grained till. In many parts of the glaciated United States similar soil groupings overlie lowland and adjacent upland areas, so basing available water-capacity and maximum recharge-rate solely on soil groupings in the SWB model would produce similar recharge values for both areas. This is contrary to research that indicates recharge through valley alluvium or outwash is about three times the recharge through till in New England (Handman and others, 1986) and Iowa (Schilling, 2009).

\section{Quaternary Sediment in the Glaciated Conterminous United States}

\section{Sediment at Land Surface}

In the United States, the glacial sediments at land surface mostly were deposited during the Late Wisconsinan glaciation, but pre-Late Wisconsinan glacial sediments are present at land surface in the western and southern tier of states in the Midwest (for example, terranes 1B, 1C, 2D, and 4B; fig. 5), and postglacial alluvium is present in stream valleys throughout the glaciated United States. The surficial sediment is mainly till (60 percent of land area covered), and outwash, lacustrine, alluvial, and ice-contact sediments comprise most of the remainder (fig. 10). Till map units are subclassified according to three texture categories in figure 10. About 6 percent of sediment at land surface is organic (peat), eolian, or marine sediments. Near the glacial margin, especially where pre-Late Wisconsinan sediments are exposed, and in mountainous areas, glacial sediment is more patchy in distribution, and colluvial sediments and residual soils are relatively

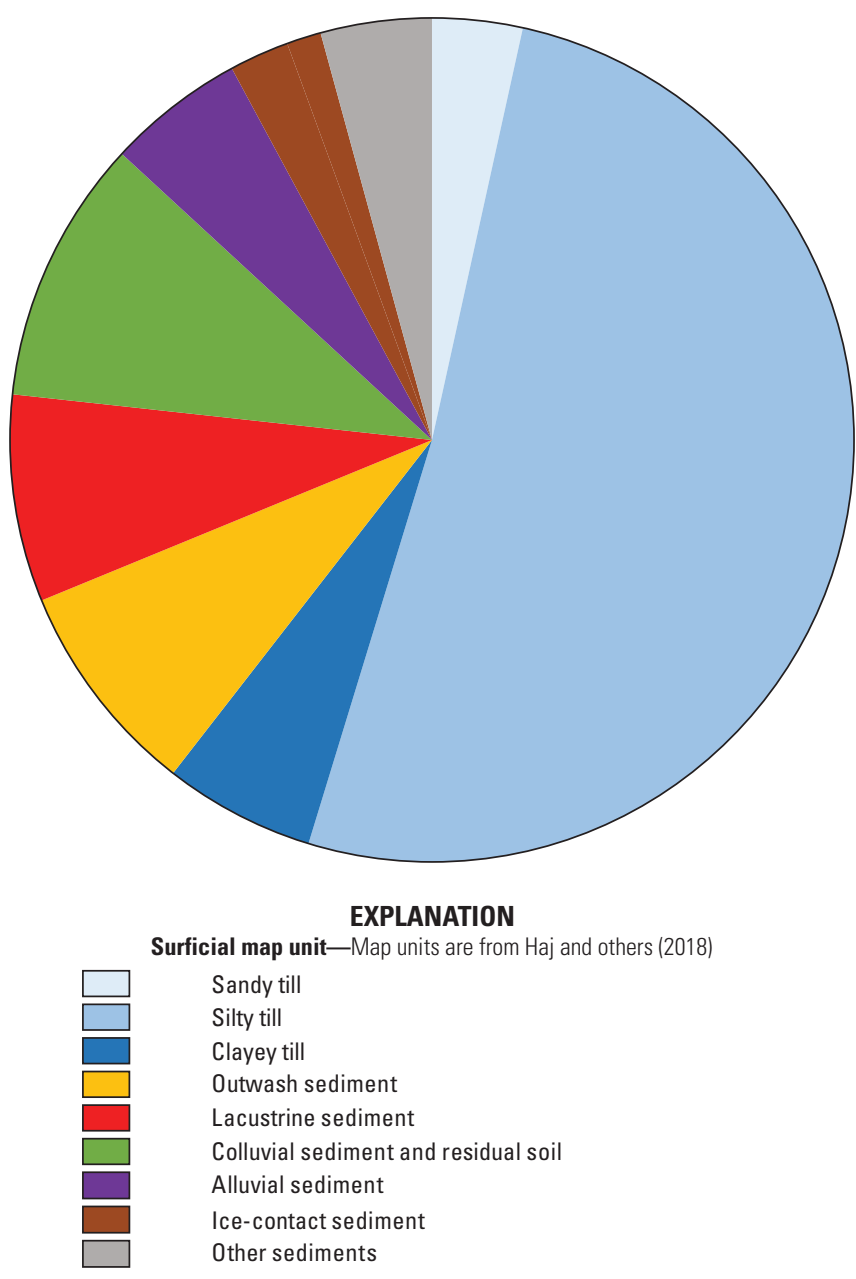

Figure 10. Percentages of land surface in the glaciated conterminous United States covered by principal; surficial map units from Haj and others (2018).

common, especially in mountainous areas of the Northeast (terrane $1 \mathrm{~A}$ ) and the Northwest (terranes $1 \mathrm{~F}$ and $1 \mathrm{G}$ ). Large areas of outwash and ice-contact sediments are preserved mainly within areas of Late Wisconsinan glaciation and are extensive throughout the Midwest, but generally are confined to valleys in the Northeast. Lacustrine sediments commonly were deposited in proglacial lakes, most prominently adjacent to the present Great Lakes, and in glacial Lake Agassiz in the eastern Dakotas and northwestern Minnesota (terranes 2A, 2E, and 3B; figs. $2 B, E$ ). Alluvial sediments are in all terranes and are of glacial and postglacial origin. Colluvial sediments and residual soils (nonglacial) primarily are present near the margins of glaciation, but also are present in valleys of Montana and North Dakota and throughout the Northwest.

The till covering most of the glaciated United States is a generally unsorted, unstratified deposit of boulders, gravel, sand, silt, and clay. For this study, the predominant till texture has been classified on the basis of surface mapping into five categories: mostly sandy, sandy-silty, mostly silty, silty-clayey, 
and mostly clayey (fig. 6). Till texture also was aggregated into three categories to simplify presentation of information in other figures in this report as sandy, silty (sandy-silty to silty-clayey), and clayey (based on mostly sandy, mostly silty, and mostly clayey from texture 4; see Haj and others, 2018, table 3). The texture reflects the provenance of the till and its mode of deposition (that is, whether it was deposited along the margins of ice lobes and therefore relatively coarsegrained, or deposited in lowlands occupied by an ice lobe and therefore contains fine-grained sediments derived from proglacial lakes). In the Northeast, till is mostly sandy where it is underlain by metamorphic bedrock in the Adirondacks of New York and in areas where plutonic bedrock is prevalent in New England. Till in other areas of the Northeast is mostly silty and generally is underlain by metamorphic and clastic (noncarbonate) sedimentary rocks (fig. 7). In the Midwest till is mostly silty, except for areas of mostly clayey till south of the Great Lakes and glacial Lake Agassiz (fig. 2D) where it is partly derived from reworked lacustrine deposits.

Till in the part of the glaciated United States that was mapped by Fullerton and Richmond (variously dated) and Haj and others (2018, fig. 1) was subclassified by type of deposition and landform: ground moraine, end moraine, or stagnation moraine. Most of the till is present in ground moraines deposited beneath glaciers during ice advance. End moraines mark locations where the glacial advance stalled and are useful for tracking and dating the recession of glaciers (fig. 5). End moraines are not only prominent features across the Midwest (for example, terranes $2 \mathrm{~A}, 2 \mathrm{C}$, and $3 \mathrm{~A}$ ), but also are notable elsewhere (for example, the Valley Heads moraine, central New York, fig. 2A). Stagnation moraines were deposited where glaciers melted in place over upland areas, and were mapped by Fullerton and Richmond (variously dated) mostly in the western Midwest (terranes 2C, 2E, and 3B). A fourth type of moraine identified in Fullerton and Richmond (variously dated), containing solifluction sediments deposited in periglacial environments near the ice front is present in the Northeast (for example, south of the Valley Heads moraine in New York) but is not separately delineated in this study.

\section{Subsurface Sediment}

Characteristics of subsurface Quaternary sediments are derived from metrics computed from the lithologic data. The metrics are displayed through box plots and maps prepared by interpolating data points on a 1-km grid, as described below.

\section{Box Plots}

Metrics computed from the lithologic data are depicted in a series of box plots grouped by map unit. The box plots show the number of data points, the median value, and a box that indicates the range of the middle half of the data (the 25 th to the 75th quartiles). The box plots are also color-coded to indicate deviations of the group medians from the median value of all data (for example, fig. 11). On some box plots with $\log$ axes, either the median, 25th quartile, or 75th quartile values are zero and, therefore, do not appear on the plot. The whiskers on the box plots indicate values within a factor of 1.5 of the interquartile range (middle 50 percent of values). Outliers at values greater or lesser than these whiskers are indicated by pluses $(+)$. Although the lithologic data were subjected to checks to eliminate errors and assure quality in the data, as described in Haj and others (2018), it was beyond the scope of this study to validate all the data. Some of the outlier data points depicted on the box plots, therefore, could reflect errors in coding the data, or the interpretation of the data obtained from Bayless and others (2017). Till texture classes are shown separately in the box plots using a three-bin classification by aggregating sandy silty, mostly silty, and silt clayey textures into the single category of silty till. The mostly organic category is omitted as few data are located in these areas.

\section{Interpolated Maps}

Maps of selected sediment and aquifer characteristics were constructed from attributes in the lithologic log database using a grid-based algorithm to interpolate between the point data. A 1-km grid was intersected with GESS map units (fig. 5). The interpolated map was constrained by grouping the point data from similar map units; for example, interpolations between data points underlying alluvial units were not grouped with data points underlying adjacent till units. Some grid cells that contain more than one map unit are subdivided into multiple parts, for example near narrow valleys that are smaller than $1-\mathrm{km}$ in width. In these cases, the procedure described below was repeated for each part of the grid cell. The maps presented in this report can be accessed through Yager and others (2018).

Weighted median values of attributes were computed using lithologic logs near each grid cell to reduce the effect of outliers and to produce a smooth interpolation. Initially all lithologic logs within a 1-km radius of a grid cell within the same map unit were selected. If at least 10 lithologic logs were not available within the $1-\mathrm{km}$ radius, the search radius was expanded as much as $20 \mathrm{~km}$ until 10 lithologic logs were selected. If less than 10 lithologic logs in the same map unit were available within the $20-\mathrm{km}$ radius, the computation proceeded with the number selected, except for the case where less than three $\operatorname{logs}$ were available. For this case the value for the cell was left blank. Each lithologic log was inversely weighted based on its distance from the cell center: logs within $1 \mathrm{~km}$ were assigned a weight of 1.0, whereas cells at $20 \mathrm{~km}$ distance were weighted as zero. Shading applied to the maps indicates the number of values used to compute the weighted median at each grid cell.

The procedure used to interpolate the thickness of the Quaternary sediments was modified slightly to incorporate information available from published maps of Soller and Garrity (2018), Jones (1999), and Ely and Kahle (2004). For grid cells where less than five lithologic logs were available within a $20-\mathrm{km}$ radius, the median value was averaged with an interpolated value from a published map surface. If no lithologic 

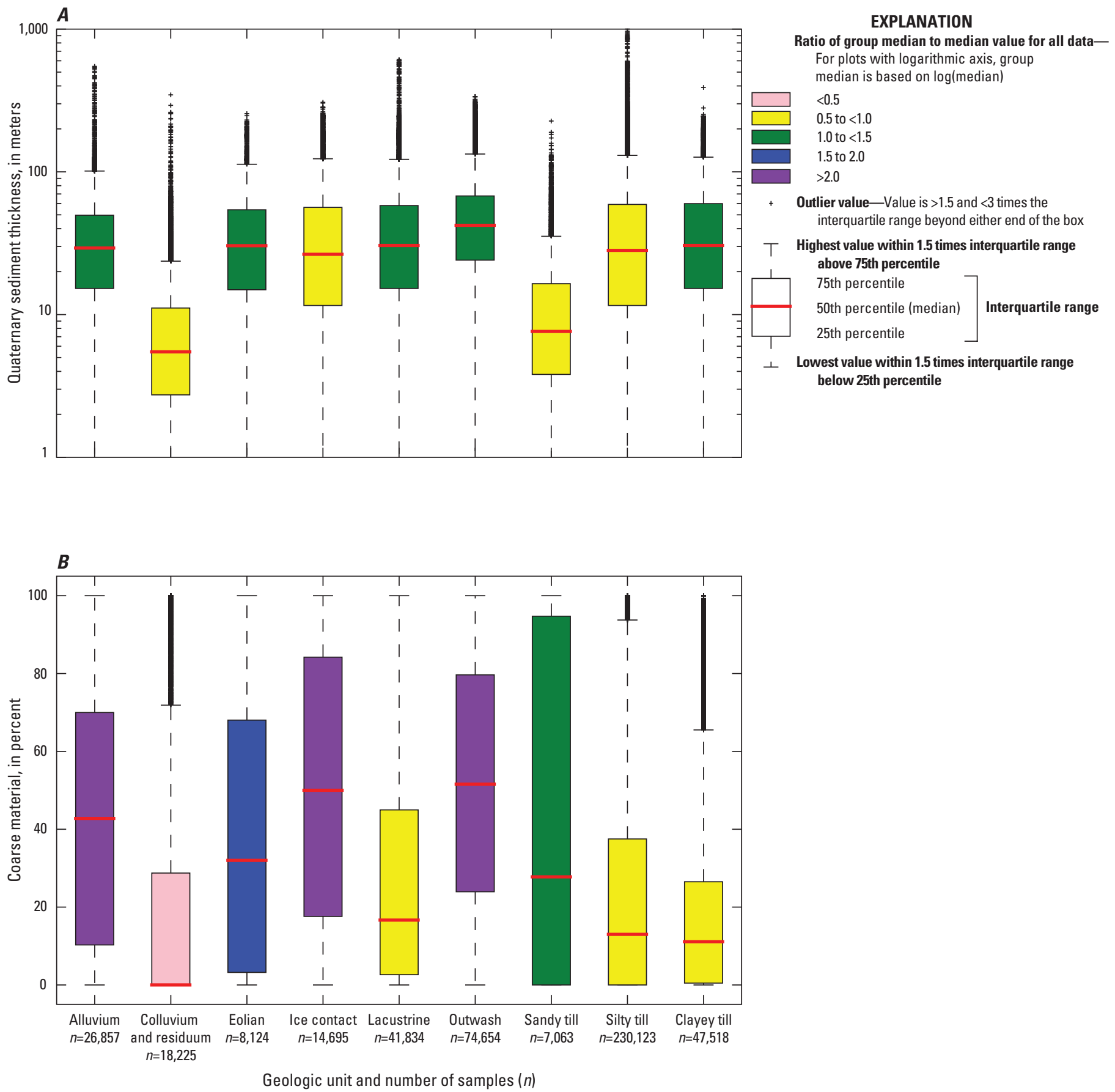

Figure 11. Metrics computed from lithologic logs grouped by map unit in the glaciated conterminous United States. $A$, Quaternary sediment thickness and $B$, percentage of coarse material. 
logs were available in areas covered by previously published maps, then the value for the cell was set to the map value. If the area was not covered by previously published maps, then the value for the cell was left blank.

\section{Subsurface Sediment Characteristics}

The median thickness of Quaternary sediment ranges from 6 to $45 \mathrm{~m}$ across the nine map units (fig. 11A), with maximum thicknesses more than $250 \mathrm{~m}$ in large areas east of Minnesota and Michigan (fig. 12A) and up to $1,000 \mathrm{~m}$ in a fault-bounded basin in the northern part of the Puget Sound (Jones, 1999). On a regional basis, sediment is thinnest across the Northeast (terrane 1A) and beyond the extent of Late Wisconsinan glaciation in the Midwest (terranes 1B, 1C, and 1D). In the Northeast, the sediment is thickest on Cape Cod and Long Island (terrane 4A); in the Midwest, the sediment is thickest in terranes 3A, 3B, 3C, and 4B; and in the Northwest, the sediment is thickest near Puget Sound (terrane 1G). In many terranes, areas of thick sediment reflect the presence of buried bedrock valleys, notably in terranes $2 \mathrm{~A}$ and $2 \mathrm{E}$.

Figure 12. Metrics of Quaternary sediment, estimated from lithologic logs, in the glaciated conterminous United States. $A$, Thickness and $B$, percentage of coarse material. Maps are available at https://doi.org/10.3133/sir20185091.

Throughout most of the glaciated United States, the deposits generally contain less than 10 percent coarse material which represents potential aquifer material. The fraction of coarse (aquifer) material is highly variable, however, and ranges from a median value near zero percent for till to more than 40 percent for alluvial, ice-contact, and outwash sediments (figs. $11 B$ and $12 B$ ). Sediment contains generally less than 10 percent coarse material throughout most of the glaciated United States (fig. 12B).

Profile plots show the frequency distribution of coarse and fine materials with depth noted in lithologic logs for Quaternary sediment within $100 \mathrm{~m}$ of land surface beneath the principal map units (fig. 13). The proportion of logs that penetrate bedrock within each depth interval also is shown on the plots. The part of the plots labeled "unknown" corresponds to logs where no information is known about the material because the bottom of the log is above the bedrock surface. Quaternary sediments beneath alluvial, ice-contact, and outwash sediments contain the highest proportions of coarse materials, as indicated by the boxplots in figure $11 \mathrm{~B}$. About 80 percent of the coarse material lies within $37.5 \mathrm{~m}$ of land surface beneath alluvial sediment and within $23 \mathrm{~m}$ of land surface beneath ice-contact and outwash sediments. Much less coarse material is beneath lacustrine and till deposits. About 80 percent of the coarse material is within $35.5 \mathrm{~m}$ of land surface beneath till and within $25 \mathrm{~m}$ of land surface beneath lacustrine sediments.

\section{Regional Patterns of Quaternary Sediment}

Across the glaciated United States, differences in topography and the history and nature of glacial deposition have produced distinct regional patterns in the distribution of Quaternary sediments; for example, in the Northeast (terrane 1A) and the Northwest (terranes $1 \mathrm{~F}$ and $1 \mathrm{G}$ ), sediments in mountainous areas are not of glacial origin, are thin or discontinuous, and have thick glacial and postglacial sediment generally concentrated in valleys. In contrast, Quaternary glacial and postglacial sediment in the Midwest forms a mostly continuous cover that in many places is substantially thicker beneath the uplands than in the valleys.

Quaternary sediment in the Midwest is the product of multiple glacial advances of the Laurentide ice sheet - as a result, the sediment is relatively thick and commonly includes confined aquifer material. In contrast, sediment in the Northeast and the Northwest largely was deposited during the Late Wisconsinan glaciation, from the Laurentide ice sheet in the Northeast and from the Cordilleran ice sheet in the Northwest. Topographic relief is much higher in the Northeast and the Northwest than in the Midwest, so that upper flanks and tops of bedrock hills and mountains are either devoid of Quaternary sediment or mantled with thin till, residuum, or colluvium. Aquifer material in the Northeast is typically unconfined, particularly in New England and eastern New York, whereas confined aquifer material is present in valleys in western New York. Aquifer material in the Northwest likely is confined, however, especially in broad valleys that contain unconsolidated basin fill.

A further difference in the regional settings is the availability of well records - the largest number of well records in the lithologic database is in the Midwest (fig. 8). As a result, the sparsity of data and the discontinuous nature of the Quaternary sediment outside the Midwest complicates the portrayal of aquifer-material characteristics in those areas.

\section{Confined and Unconfined Aquifers in Quaternary Sediments in the Glaciated Conterminous United States}

The previous section addressed the distribution of texture and thickness of Quaternary sediment in the glaciated United States on the basis of surficial mapping and analysis of lithologic logs. In this section, the distribution of confined and unconfined aquifers in Quaternary sediments (the Quaternary aquifers) and groundwater use is discussed on the basis of aquifer-material intervals detected in lithologic logs and the depths of water wells. The distribution of recharge computed by the SWB model is also presented, along with a discussion of source aquifers of public-water supplies compiled in a database from State well records. 

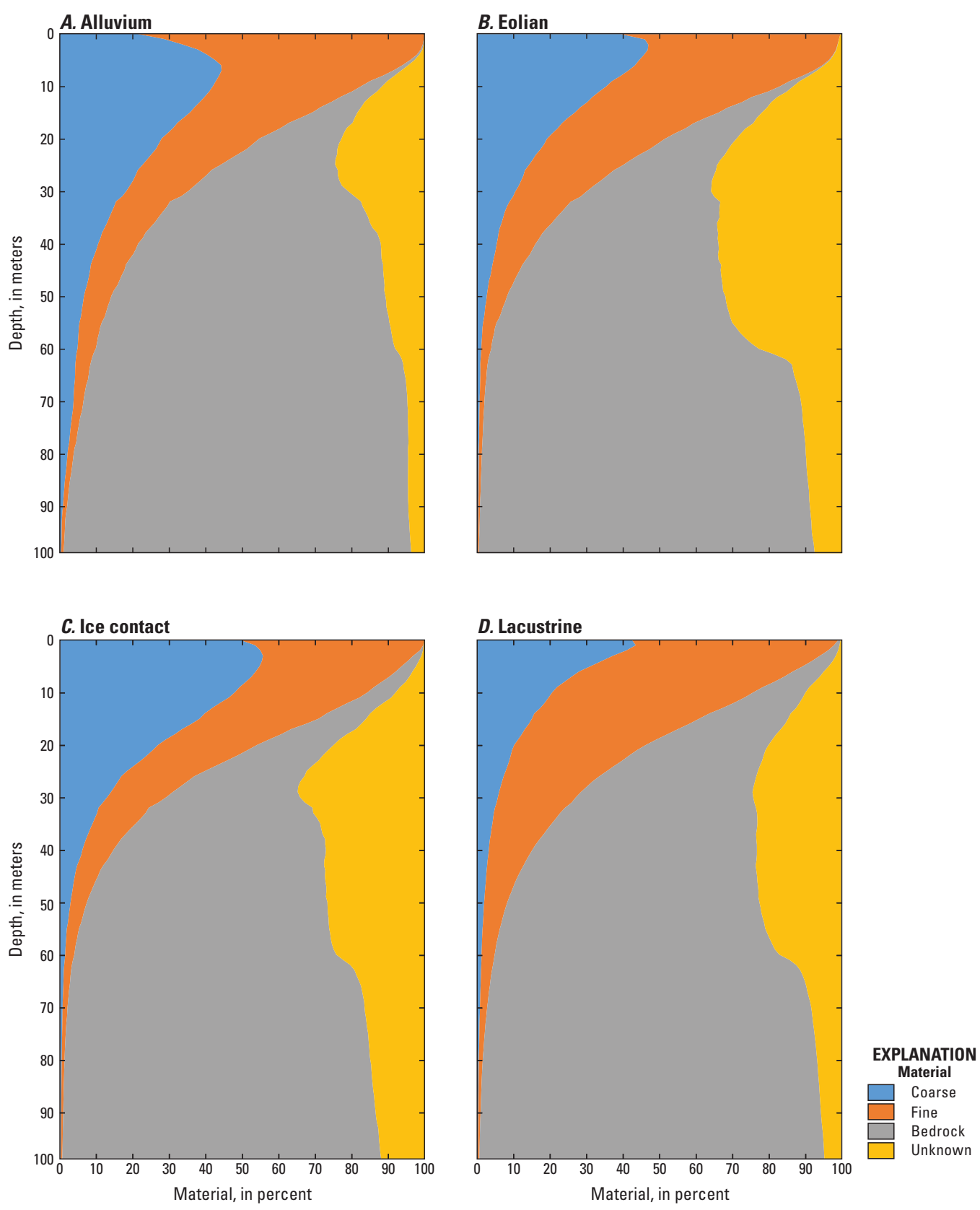

Figure 13. The frequency distribution of coarse and fine materials with depth beneath map units in the glaciated conterminous United States. $A$, Alluvium; $B$, eolian; $C$, ice contact; $D$, lacustrine; $E$, outwash; $F$, till; and $G$, nonglacial sediments (primarily colluvium and residuum). 

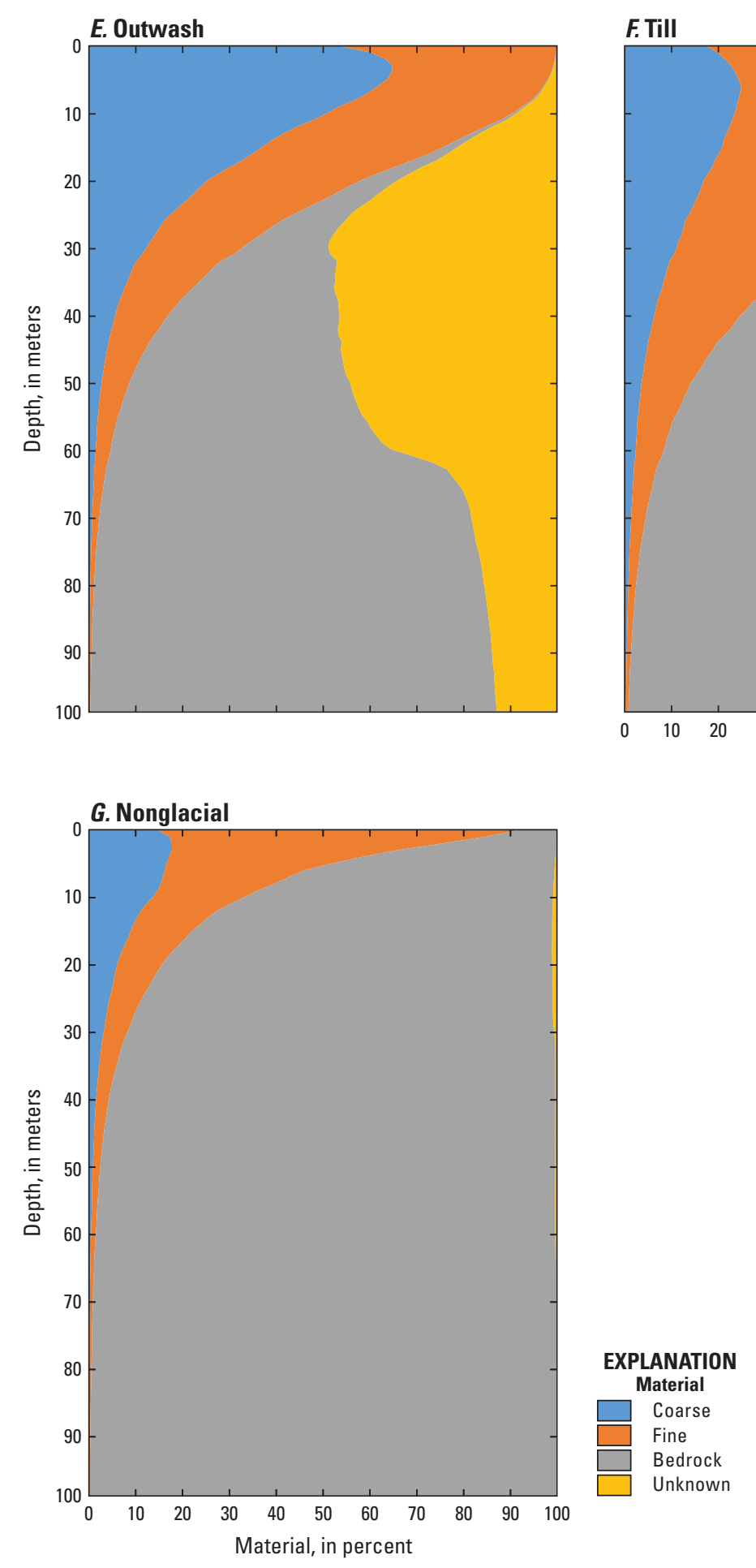

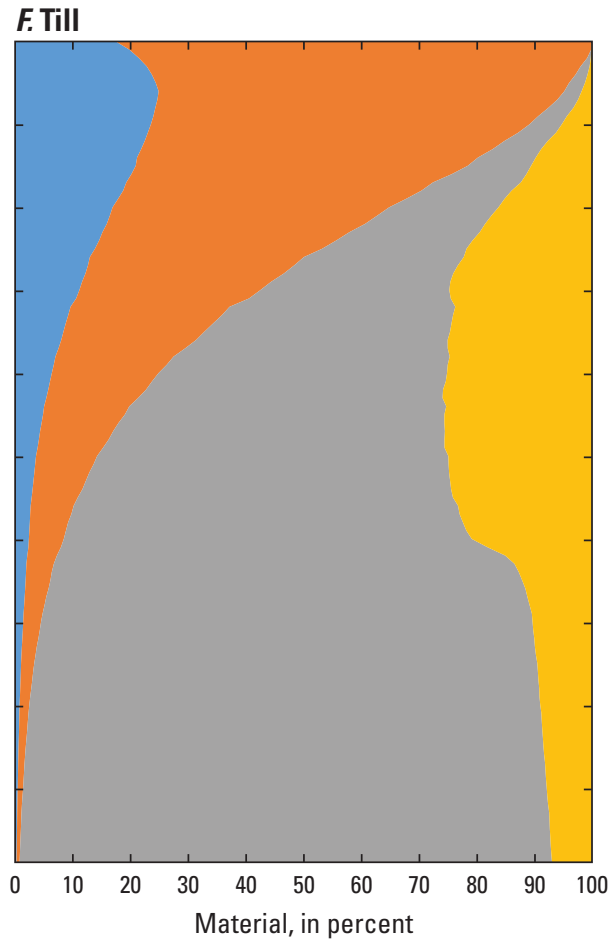


In many areas of the glaciated United States, there is a small likelihood of penetrating aquifer material at least $3 \mathrm{~m}$ thick, based on the frequency of aquifer-material intervals penetrated in lithologic logs (fig. 14). About 44 percent of the lithologic logs do not record a single aquifer-material interval (fig. 15). In about 45 percent of the logs, a single interval was recorded, whereas the remaining logs record multiple intervals. In the Northeast, single aquifer-material intervals are penetrated mainly in stream valleys and throughout eastern Massachusetts. In the Midwest, single aquifer-material intervals are reliably penetrated in widespread areas of terranes $2 \mathrm{~B}$, $3 \mathrm{~A}$, and $3 \mathrm{~B}$, as well as large portions of terranes $2 \mathrm{~A}$ and $2 \mathrm{C}$. Multiple intervals are penetrated in terrane $4 \mathrm{~A}$ in the Northeast, in terranes 3A, 3B, and 4B in the Midwest, and near the Puget Sound in the Northwest (terrane 1G).

Figure 14. Aquifer-material intervals (at least 3 meters of coarse material) penetrated by lithologic logs in the glaciated conterminous United States. $A$, Median number of intervals and $B$, probability of penetrating at least one interval. Maps are available at https://doi.org/10.3133/sir20185091.

The depths to the aquifer-material intervals penetrated by lithologic logs are highly variable. Median depths are quite shallow (less than $3 \mathrm{~m}$ ) under ice-contact and outwash sediments and under sandy till (fig. 16A). About 75 percent of the top of aquifer-material intervals in these areas are less than $10 \mathrm{~m}$ deep, although maximum depths can be more than $100 \mathrm{~m}$. The median depths range from $9 \mathrm{~m}$ under alluvial sediments to $18 \mathrm{~m}$ under clayey till, where 75 percent of the depths are less than $30 \mathrm{~m}$. The deepest intervals are in the Midwest, in terranes 2A, 2C, 3B, 3C, and 4B (fig. 17A). The range of thicknesses of aquifer-material intervals is less variable than

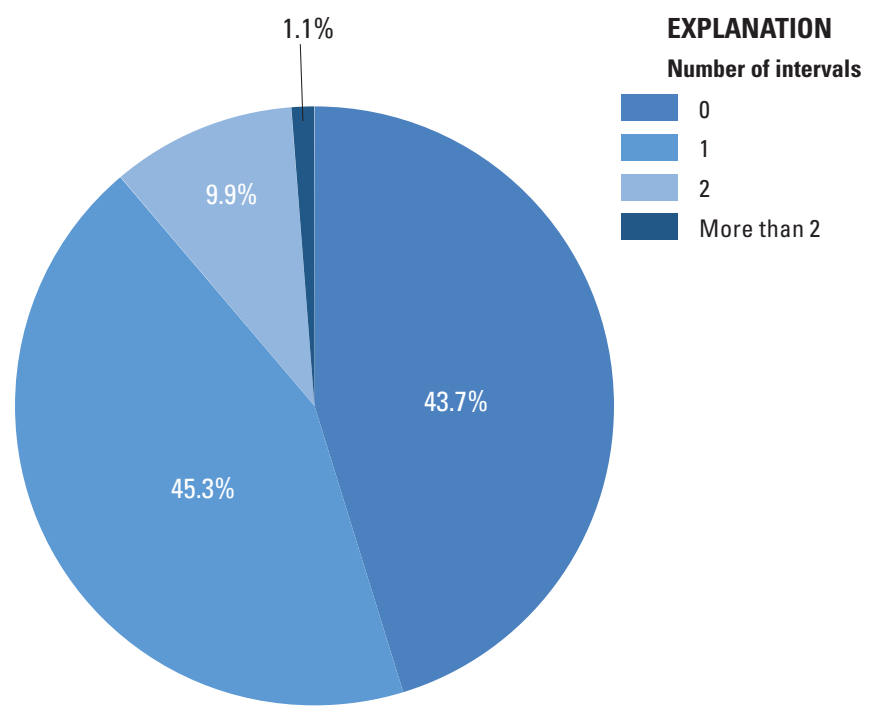

Figure 15. Number of aquifer-material intervals (at least 3 meters of coarse material) penetrated by lithologic logs in the glaciated conterminous United States. the range in depths (fig. 16B). Median thickness is less under lacustrine sediments and till (about $10 \mathrm{~m}$ ) than under the other sediments (15 to $20 \mathrm{~m}$ ). The interquartile thickness range of the deepest aquifer-material intervals is 7 to $40 \mathrm{~m}$, although at many locations thicknesses are more than $50 \mathrm{~m}$. The thickest intervals are in tributary valleys to the Missouri and Mississippi Rivers in Wisconsin, Illinois, and Nebraska (fig. 17B).

The lithologic database contains 740,727 records of water wells completed in the glaciated United States. About 44 percent of water wells are completed in Quaternary sediment, and slightly more (48 percent) are completed more than $7.5 \mathrm{~m}$ into bedrock (fig. 18A). About 8 percent of water wells are completed within $7.5 \mathrm{~m}$ below the bedrock surface, suggesting these wells near the bedrock surface produce groundwater from the sediment and bedrock. Based on the lithologic logs, 33 percent of the Quaternary wells are where the deepest aquifer-material intervals are confined by at least $7.5 \mathrm{~m}$ of fine materials (fig. 18B), whereas about 42 percent of Quaternary wells seem to tap aquifers that are unconfined. About onequarter of the Quaternary wells are where the sediments are mostly fine-grained and with only thin layers (less than $3 \mathrm{~m}$ ) of coarse material. The median depths of Quaternary water wells ranges from 13 to $40 \mathrm{~m}$, and the wells are generally deeper in terranes $1 \mathrm{G}$ and $3 \mathrm{C}$ (fig. 19A; water wells in terrane 4B are not included on figure 19 because the well use was not noted in the lithologic log). The depth of 50 percent of the wells ranges from 10 to $70 \mathrm{~m}$. The Quaternary wells penetrate most of the sediment thickness in the type " 1 " terranes and much less of the sediment thickness in the type " 3 " and " 4 " terranes (fig. 19B). Sediment thickness is generally not well known in terrane $1 \mathrm{G}$, so no data are plotted on figure $19 B$.

The thickness of unconfined (water table) aquifermaterial intervals ranges from less than $5 \mathrm{~m}$ to greater than $50 \mathrm{~m}$ (fig. 20A). Thick unconfined intervals are present within several areas of the glaciated United States. In the Northeast, thick unconfined intervals are throughout Cape Cod and Long Island in terrane 4A, and in parts of the Adirondacks of New York in terrane 1A. Thick unconfined intervals in the Midwest are in Wisconsin in terrane 2B, in the Missouri valley between Iowa and Nebraska in terrane 2D, and at the downgradient end of the Mahomet-Lafayette aquifer system in Illinois in terrane 1B. Thick unconfined intervals also underlie Puget Sound in the Northwest in terrane $1 \mathrm{G}$.

The percentage of aquifer-material intervals that are confined is shown in figure $20 B$ as a conditional probability, based on the frequency of aquifer-material intervals overlain by $7.5 \mathrm{~m}$ or more of fine-grained material, if the lithologic log penetrated an aquifer-material interval. Areas where aquifermaterial intervals were not penetrated are masked by gray shading on the figure. Confined aquifer-material intervals are most likely in large parts of the Midwest, including Illinois, Indiana, and Ohio in terrane 2A, and North Dakota extending south through Minnesota into Iowa and Nebraska in terranes 2D, 2E, 3B, 3C, and 4B. Confined intervals also are in parts of New York in terrane $1 \mathrm{~A}$ and in valleys of the West in terranes $1 \mathrm{~F}$ and $1 \mathrm{G}$. 

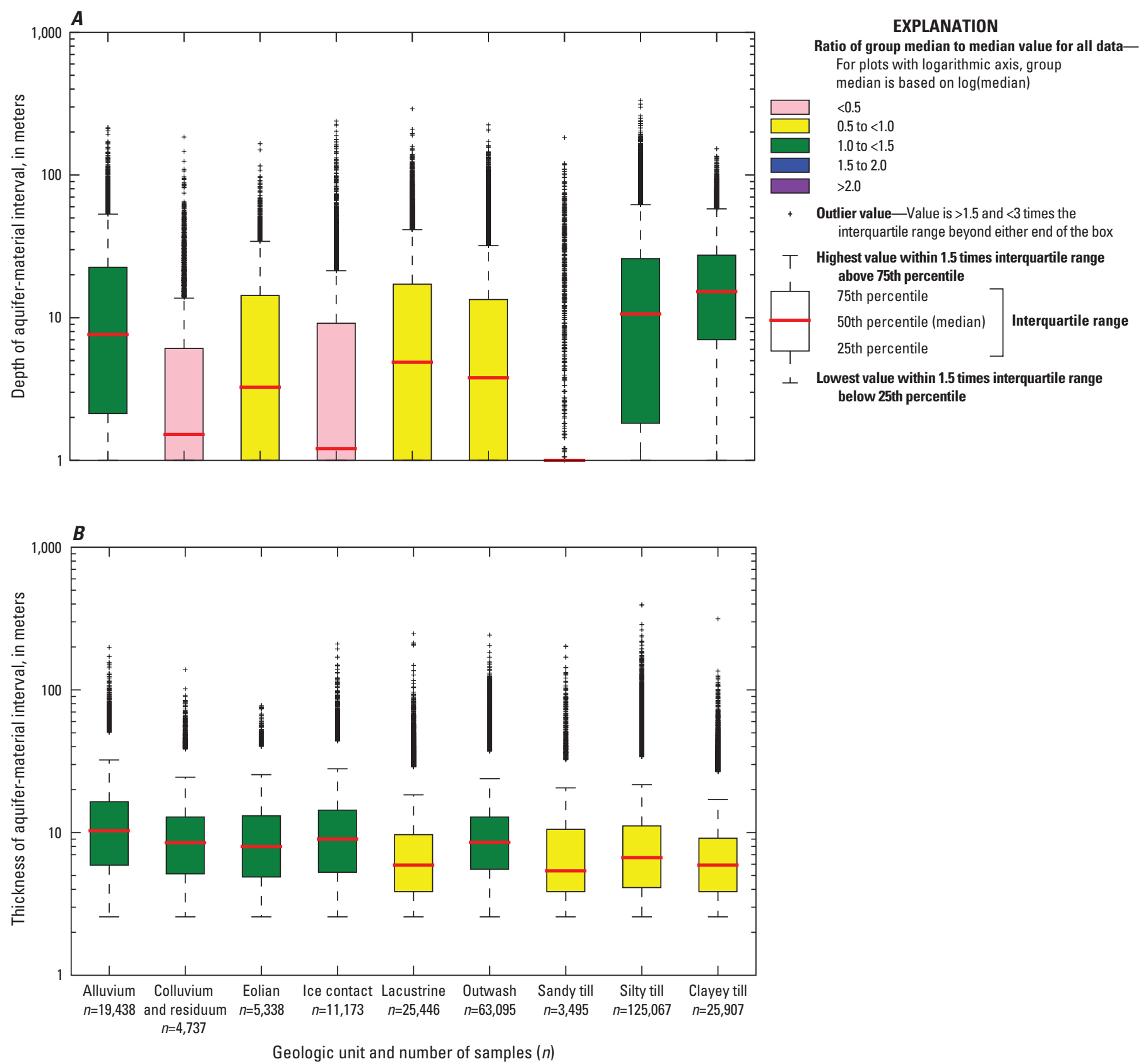

Figure 16. Metrics computed from lithologic logs grouped by map unit in the glaciated conterminous United States. $A$, Depth and $B$, thickness of bottom aquifer-material intervals.

Figure 17. Aquifer characteristics, estimated from lithologic logs, in the glaciated conterminous United States. $A$, Median depth to bottom aquifer-material interval and $B$, median thickness of bottom aquifer-material intervals. Maps are available at https://doi.org/10.3133/sir20185091.

\section{Recharge}

The magnitude and distribution of recharge computed by the SWB model for the glaciated United States reflects the variability in climate and the distribution of Quaternary sediment at land surface across the area (fig. 21). More recharge is computed for the Northwest (terrane 1G) and the Northeast (terrane 1A), where the precipitation is highest and the evapotranspiration is lowest, than for other terranes. More recharge also is computed for lowlands and valleys underlain by coarse-grained sediment than for upland areas covered by fine-grained sediment and till. This pattern is most evident in the Midwest (for example, terrane 2D) where recharge is low and more muted than in the Northeast where recharge is high. 
$\boldsymbol{A}$

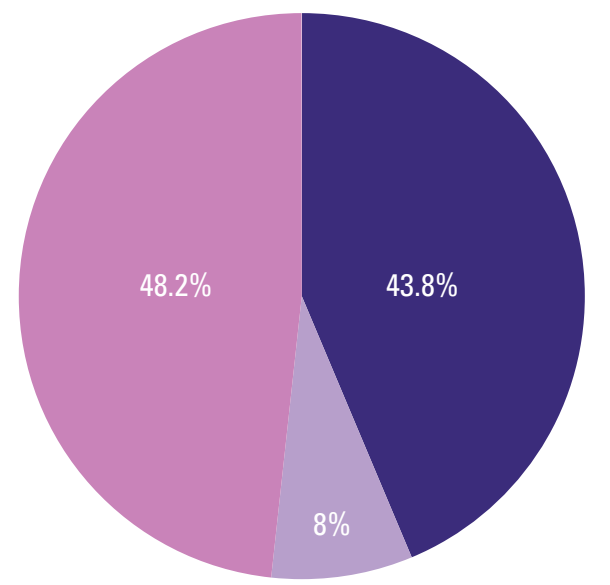

B

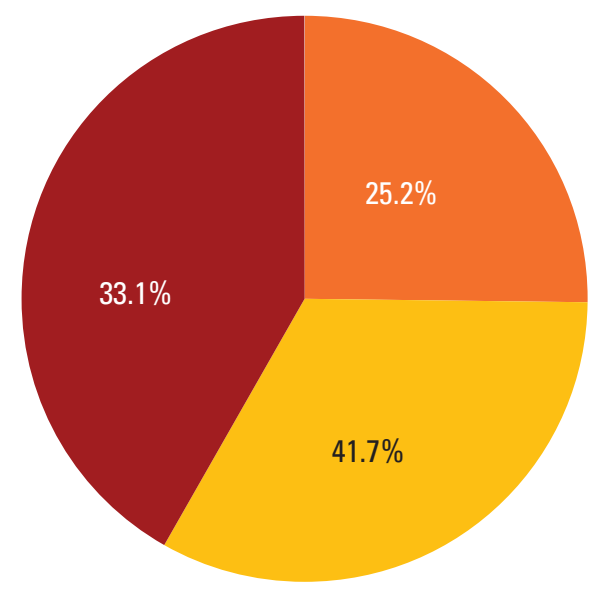

Figure 18. Percentages of water wells in the glaciated conterminous United States. $A$, Wells completed in Quaternary sediment, top of rock, and bedrock; and $B$, Quaternary water wells under confined and unconfined conditions or under mostly fine-grained sediment.

The median recharge for the glaciated United States is 136 millimeters per year ( $\mathrm{mm} / \mathrm{yr})$, but ranges from less than $10 \mathrm{~mm} / \mathrm{yr}$ in terrane $1 \mathrm{~F}$ to greater than $400 \mathrm{~mm} / \mathrm{yr}$ in terranes $1 \mathrm{~A}$ and $4 \mathrm{~A}$ (fig. 22). The largest variability in recharge is computed for terrane $1 \mathrm{G}$, where the median is $200 \mathrm{~mm} / \mathrm{yr}$, but the interquartile range is 35 to $550 \mathrm{~mm} / \mathrm{yr}$. The low recharge areas in terrane $1 \mathrm{G}$ are in the rain shadows of the Cascade and Rocky Mountains, whereas the mountainous areas receive the highest recharge.

Residual plots showing the agreement between recharge computed by the SWB model and the base flow estimated for 435 gaged watersheds in the glaciated United States using the program PART (Rutledge, 1998) are presented in appendix 1 (figs. 1.1, 1.2). The agreement is good with a coefficient of determination of 0.86 (fig. $1.3 A$ ), although the SWB recharge estimates are higher than PART base flow estimates in the southern Midwest and lower in the upper Midwest (fig. 1.4A). It is important to note that the PART base flow estimates also are subject to error, especially in large watersheds in the upper Midwest where diversions can affect base flow, and in mountainous areas where snowmelt contribution to base flow is substantial.

\section{Distribution of Groundwater Usage}

Total groundwater usage compiled by county in the glaciated United States in 2010 (Maupin and others, 2014) ranges from less than 1 to $370 \mathrm{~mm} / \mathrm{yr}$ on an areal basis (fig. 23A; table 1). Total groundwater withdrawals were 13,753 million cubic meters per year (11.3 million acre-feet per year; table 1); a volume of water equivalent to $7.4 \mathrm{~mm}$ across the 1.87-million square kilometer area of the glaciated United States. The largest withdrawals are on Cape Cod and Long Island in terrane $4 \mathrm{~A}$, and in a few counties scattered throughout the Midwest in terranes 1B, 2A, 3B, and 4B. Groundwater withdrawals from public-water systems total 5,082 million cubic meters per year (4.1 million acre-feet per year; table 1), $2.7 \mathrm{~mm}$ across the glaciated United States or 37 percent of total withdrawals. Groundwater withdrawals from publicwater systems compiled for this study total 5,367 million cubic meters per year (table 1), close to the value cited above from Maupin and others (2014), although values estimated for individual states vary. Possible explanations for these discrepancies are discussed in Haj and others (2018).

County withdrawal rates for public-water supply range from less than $1 \mathrm{~mm} / \mathrm{yr}$ in the western United States to greater than $100 \mathrm{~mm} / \mathrm{yr}$ on Long Island (fig. 23B). Withdrawals by county range from 5 to $40 \mathrm{~mm} / \mathrm{yr}$ over large areas of the Midwest and the Northeast. Quite a few counties in the Midwest from Illinois through Iowa and Missouri and into the Dakotas report no withdrawals for public supply. The percentage of groundwater usage for public-water supply that is derived from Quaternary sediments varies across the glaciated United States (fig. 23C). Quaternary sediments are main source of groundwater for public supply over most of the area, especially in the lower Midwest (Michigan, Indiana, and Illinois), the upper Midwest (Minnesota and the Dakotas), and the Northwest. Groundwater from bedrock provides public supplies where Quaternary sediments are thin in Missouri, northwestern Ohio, northeastern Iowa, and southern Wisconsin, and in many counties throughout the Northeast and Montana.

A map showing the ratio of groundwater withdrawals to recharge indicates three areas in Nebraska, South Dakota, and Montana that are at risk for groundwater depletion, where withdrawal rates exceed recharge rates (fig. 24). These are areas where recharge rates are low and groundwater also is used for irrigation. Groundwater withdrawals are less than 10 percent of recharge throughout most the glaciated United States, but are a larger proportion of recharge near urban areas in the Northeast and the Midwest and in counties throughout drier parts of the Midwest. 

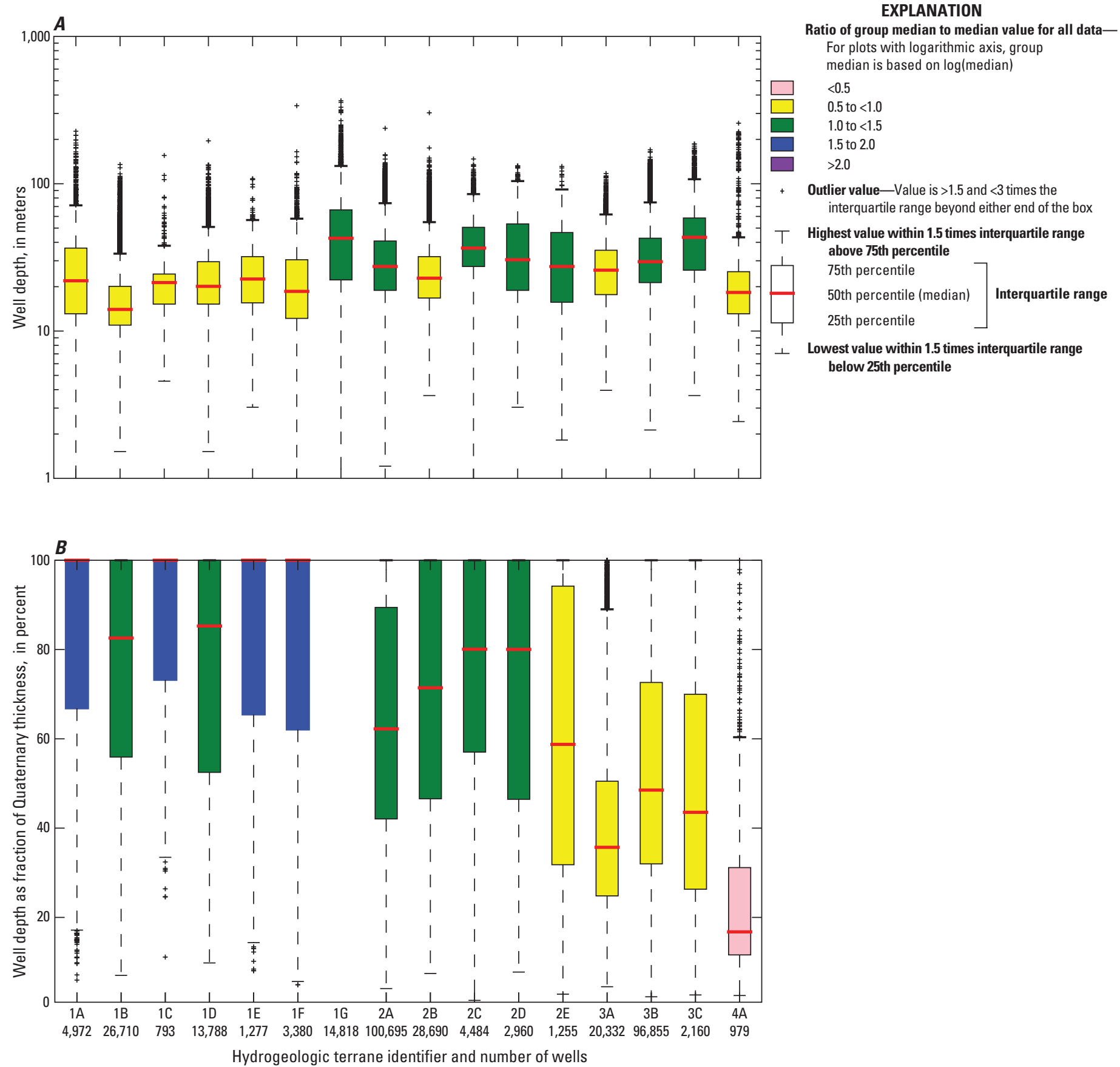

Figure 19. Water wells completed in Quaternary sediment by hydrogeologic terrane in the glaciated conterminous United States. $A$, Well depth and $B$, well depth as percentage of sediment thickness.

Figure 20. Confined and unconfined aquifer-material interval characteristics in the glaciated conterminous United States. $A$, Thickness of unconfined (water-table) aquifer-material intervals and $B$, probability that an aquifer-material interval is confined, if present. Maps are available at https://doi.org/10.3133/sir20185091.
Figure 21. Annual recharge in the glaciated conterminous United States based on the soil-water balance model. Map is available at https://doi.org/10.3133/sir20185091. 


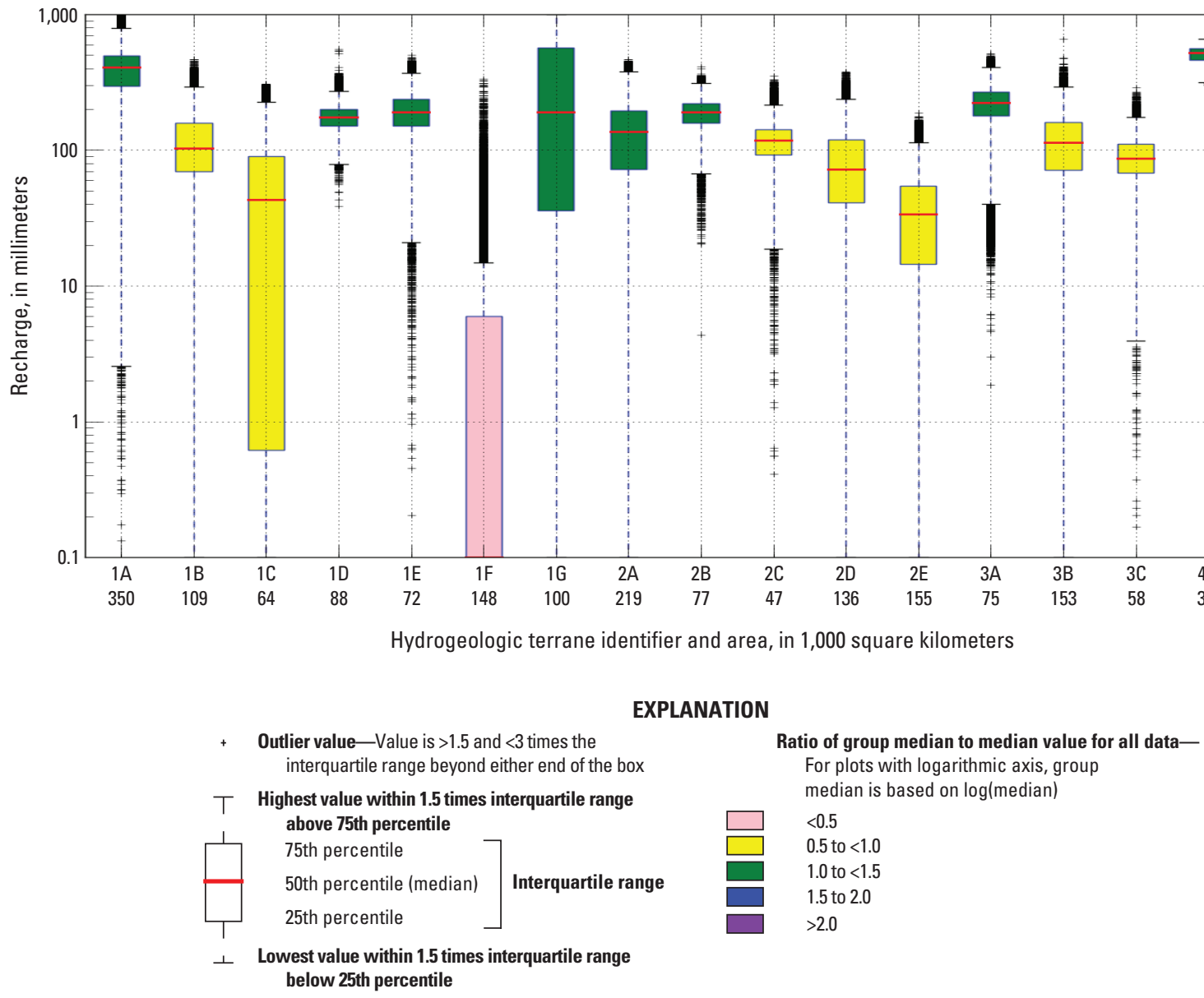

Figure 22. Annual recharge by hydrogeologic terrane in the glaciated conterminous United States.

Figure 23. Distribution of groundwater use, by county, in the glaciated conterminous United States. $A$, Total annual groundwater withdrawals in 2010; $B$, annual public-supply groundwater withdrawals in 2010; and $C$, percentage of publicsupply groundwater withdrawals from Quaternary sediments. Maps are available at https://doi.org/10.3133/sir20185091.
Figure 24. Annual groundwater withdrawals in 2010 as a ratio to recharge, by county, in the glaciated conterminous United States. Map is available at https://doi.org/10.3133/sir20185091. 


\section{Sediment and Aquifer Characteristics of Hydrogeologic Terranes}

According to the four criteria noted in the previous "Hydrogeologic Terranes" section, the Quaternary-age deposits (including sediments of glacial and nonglacial origin) within the glaciated United States are classified into 17 hydrogeologic terranes. To assist in differentiating the various terranes, each is assigned a numeric code that denotes, in a relative sense, the complexity of the subsurface glacial geology - terranes of "lower" stratigraphic complexity are assigned code $=1$, terranes of "moderate" complexity are assigned code $=2$, and those of "higher" complexity are assigned code $=3$. This ranking is highly generalized and is used only to give the reader a sense of the relative potential for penetrating confined and unconfined aquifers. To differentiate the various terranes of similar general complexity, letter designations were appended to the numeric codes (for example, 1A, 3C). Two areas where stratified, coarse-grained sediment dominates were assigned code $=4$ to differentiate them from the other terranes, which are composed mostly of till. For all terranes, glacial and nonglacial (for example, interglacial or postglacial sediment of fluvial or eolian origin) deposits of Quaternary age are included. In this section, the salient characteristics of each hydrogeologic terrane are described. A set of descriptive plots are included to facilitate visual comparisons between selected surface and subsurface characteristics of the terranes.
The proportion of mapped geologic-material units within each hydrogeologic terrane is shown in figure 25 . The thickness of Quaternary sediment generally increases from the lower complexity terranes through the higher complexity terranes, consistent with the delineation of the terranes (fig. 26A). The proportion of coarse material in Quaternary sediment is highly variable (fig. 26B), but several terranes (2B, 3A, 4A, and $4 \mathrm{~B}$ ) contain a much larger percentage of coarse-grained sediment than others (1A, 1B, 1C, 1D, and 2C).

The depth to aquifer-material intervals also is highly variable (fig. 27A). Several terranes (1A, 1D, 1E, and 4A) have median depths of zero, indicating that most intervals begin at land surface and hence are unconfined. In contrast, two terranes ( $2 \mathrm{C}$ and $4 \mathrm{~B}$ ) have median depths approaching $30 \mathrm{~m}$, indicating that most intervals probably are confined. The median thicknesses of aquifer-material intervals in most terranes generally fall within a narrow range of 10 to $20 \mathrm{~m}$ (fig. 27B), except in terranes 4A and 4B, where median thicknesses are $30 \mathrm{~m}$ or more, consistent with their delineation as areas with thick coarse-grained sediment.

The number of aquifer-material intervals penetrated by wells in each hydrogeologic terrane is shown in figure $28 \mathrm{~A}$. At many locations, no coarse-grained intervals greater than $3 \mathrm{~m}$ in thickness were penetrated. Where aquifer-material intervals were penetrated, only a single interval generally was present, but multiple intervals commonly were penetrated in several terranes, especially in 3B, 4A, and 4B. The source of water in wells varies widely across the glaciated United States from mostly bedrock wells in the lower complexity terranes

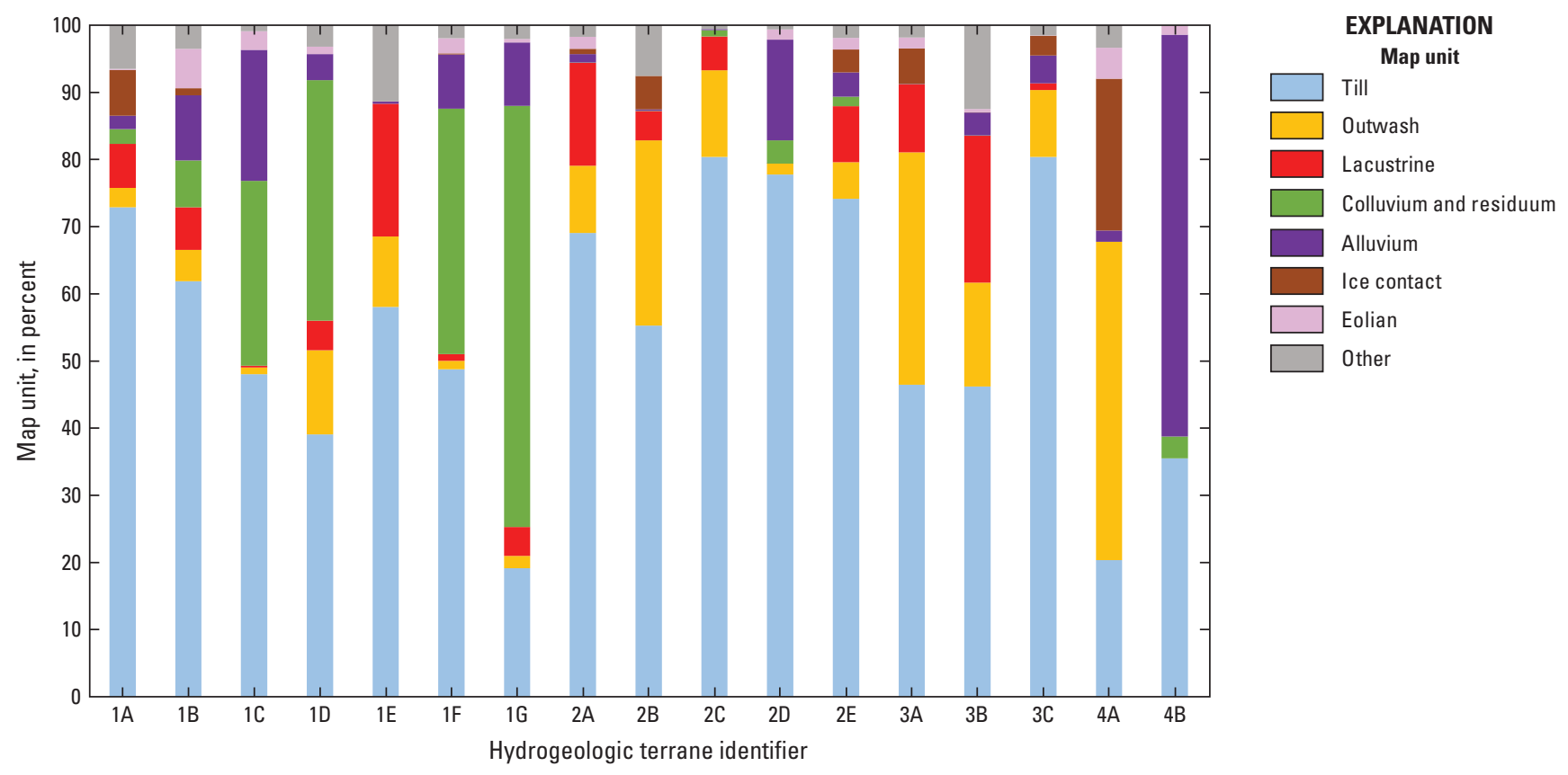

Figure 25. Proportions of map units within each hydrogeologic terrane in the glaciated conterminous United States. 

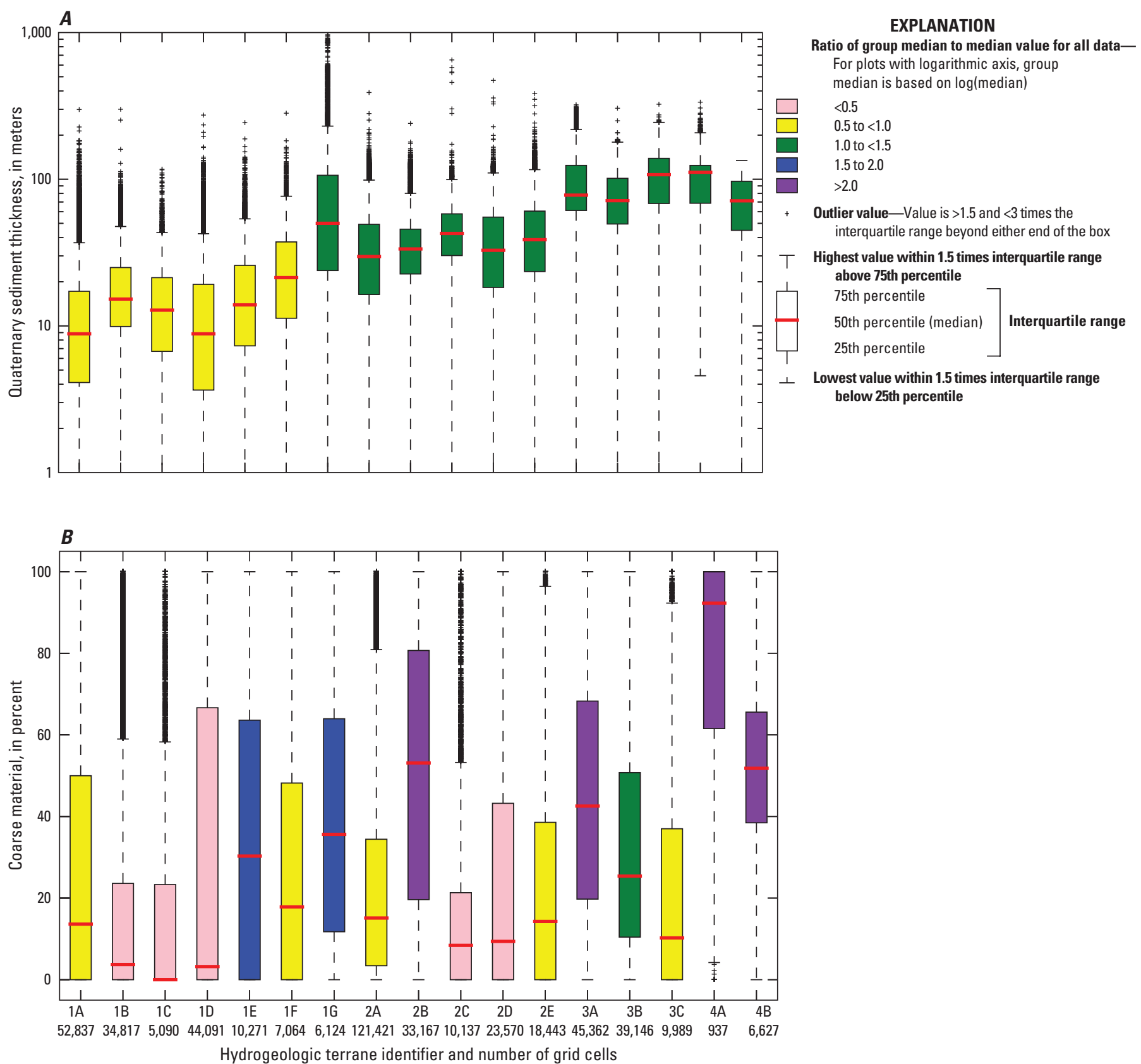

Figure 26. Sediment and coarse material characteristics grouped by hydrogeologic terrane in the glaciated conterminous United States. $A$, Thickness of Quaternary sediment and $B$, percentage of coarse material. 

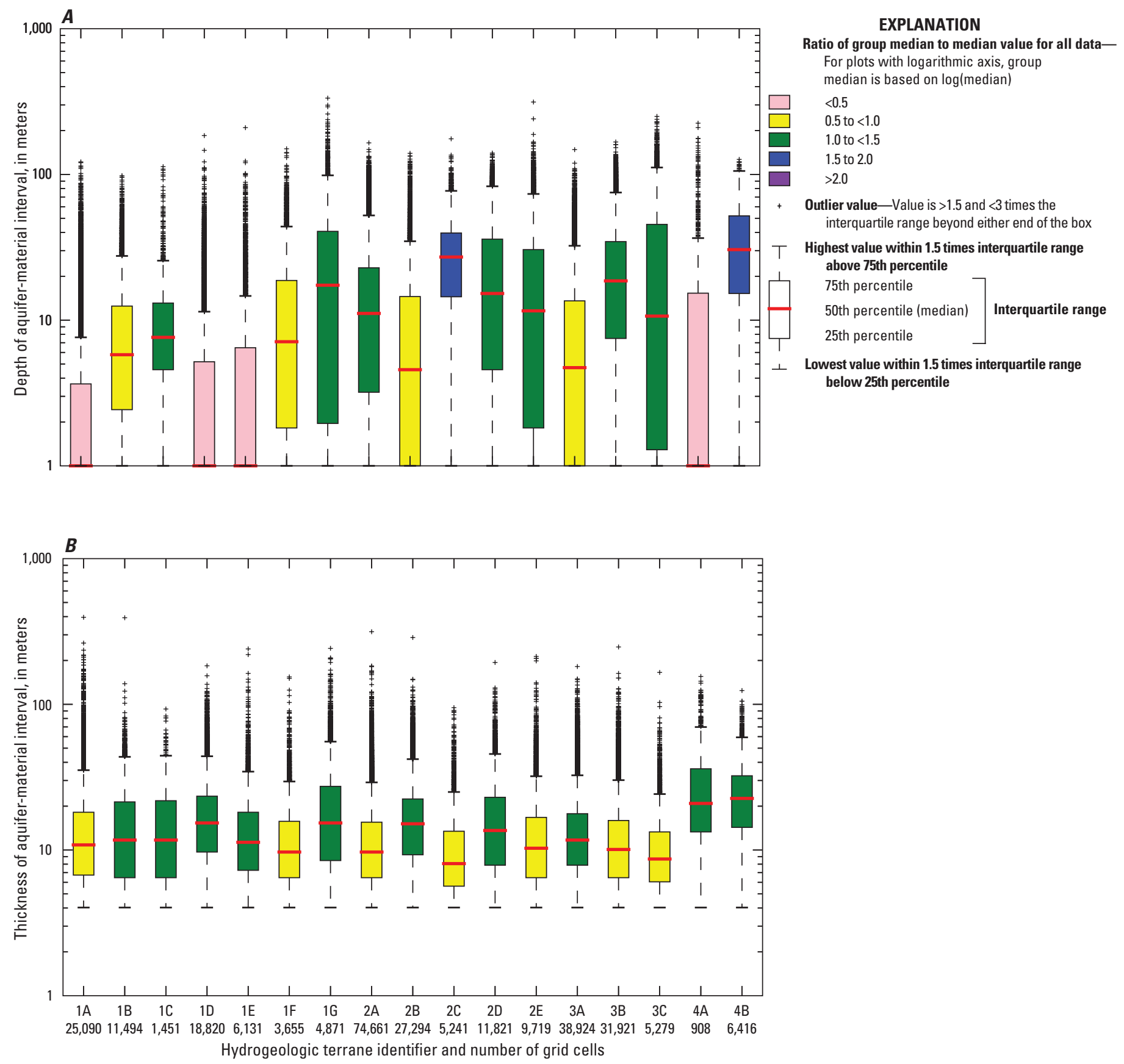

Figure 27. Aquifer-material interval characteristics grouped by hydrogeologic terrane in the glaciated conterminous United States. $A$, Depth of aquifer-material intervals and $B$, thickness of aquifer-material intervals. 


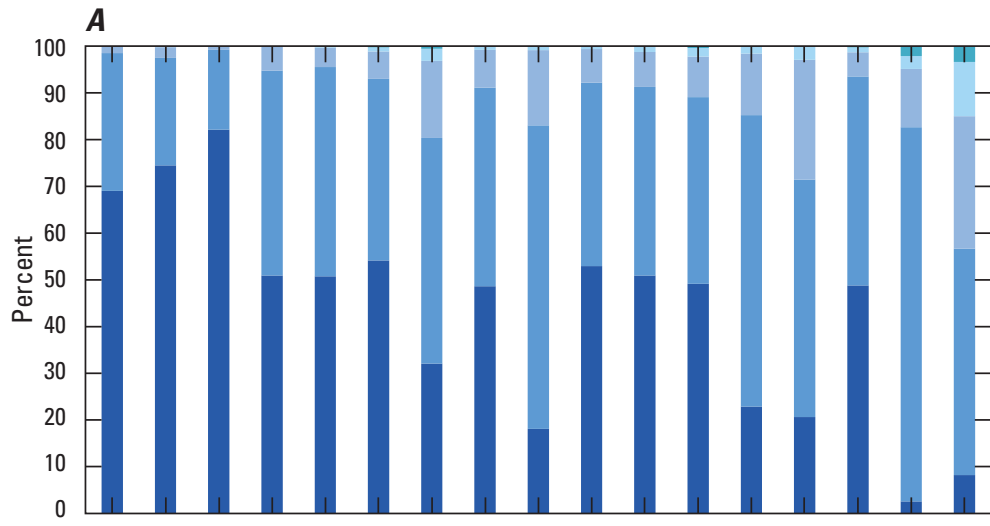

\section{EXPLANATION \\ Numbers of aquifer-material \\ intervals}

$\square$
$\square$
$\square$
$\square$
$\square$
$\square 4$
$\square \geq$
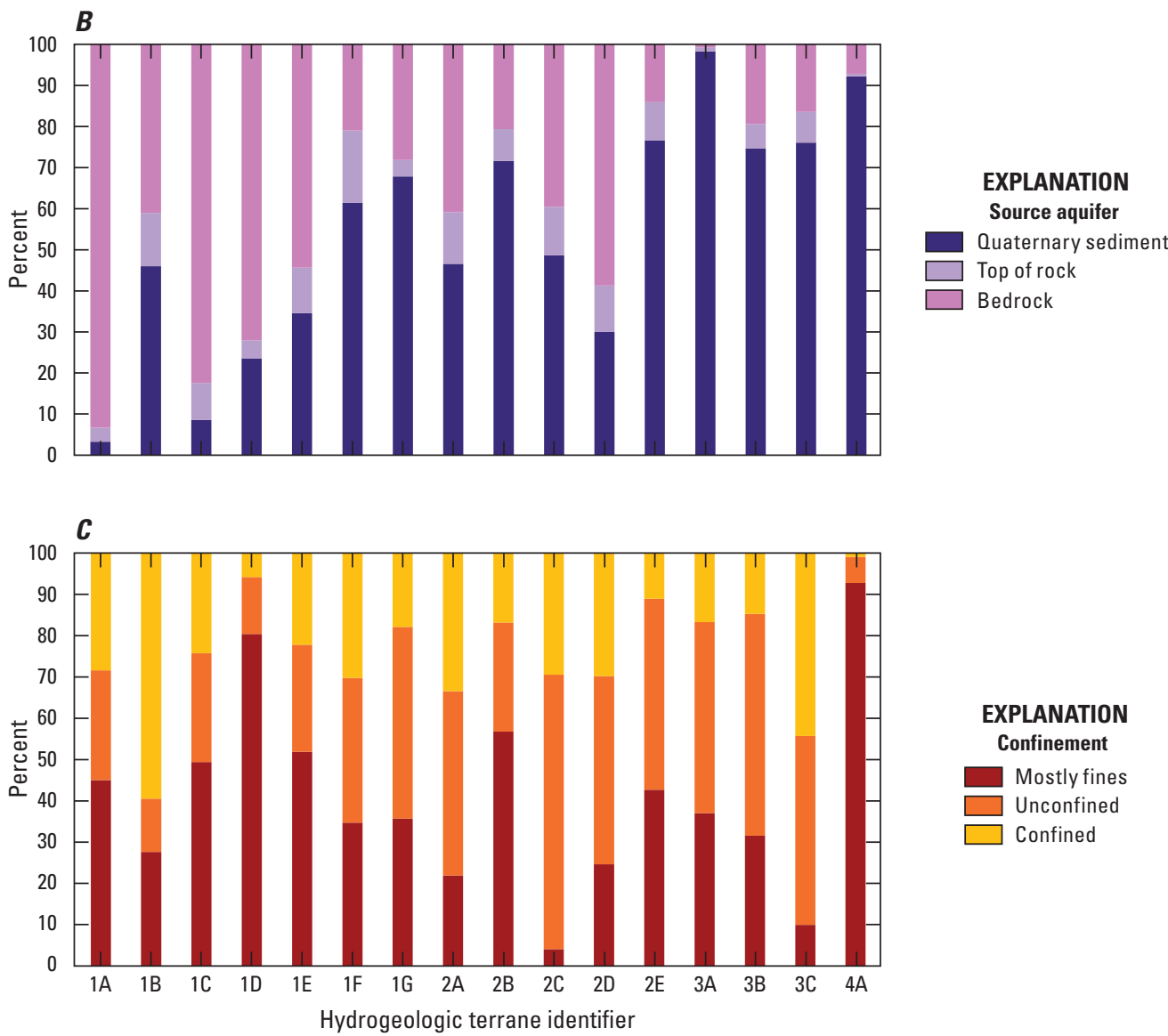

Figure 28. Water well characteristics grouped by hydrogeologic terrane in the glaciated conterminous United States. $A$, Number of aquifer-material zones penetrated by lithologic logs; $B$, percentage of water wells completed in Quaternary sediment, top of rock, and bedrock; and $C$, percentage of Quaternary water wells completed under confined and unconfined conditions or under mostly fine-grained sediment. 
to mostly Quaternary wells in the higher complexity terranes (fig. 28B); this is because Quaternary sediment generally is thicker in the higher complexity terranes, so the likelihood of penetrating an aquifer in those sediments is higher than in the lower complexity terranes, where the sediment is thinner (water wells in terrane 4B are not included on fig. $28 B$ and $C$ because the well use was not noted in the lithologic log). The confinement in Quaternary wells also varies across the area (fig. 28C) from mostly unconfined wells in terranes 1D, $2 \mathrm{~B}$, and $4 \mathrm{~A}$, to mostly confined wells in terranes $2 \mathrm{C}$ and $3 \mathrm{~B}$, where aquifer-material intervals are deeper and predominantly overlain by fine-grained materials.

\section{Hydrogeologic Terranes of Lower Complexity}

\section{Terrane 1A—Predominantly Late Wisconsinan Sediment in Eastern Ohio Through New England}

Hydrogeologic terrane 1A consists of mostly thin Quaternary sediment and exposed bedrock (mixed sedimentary rocks, and igneous (plutonic) and metamorphic rocks; fig. 7). The physiography of this broad area, east of the Appalachian Escarpment in Ohio, varies considerably and includes high relief in several mountain ranges (Adirondack, Catskill, Taconic, Green, and White Mountains), moderate relief in the dissected Appalachian Plateau and New England Uplands, and low relief in lowlands formerly occupied by proglacial lakes or marine waters (fig. $2 A$ ).

In general, the terrane is characterized by thin (generally less than $15 \mathrm{~m}$ ) or patchy till and exposed bedrock on the uplands and fine- to coarse-grained stratified sediment in the valleys and lowland areas (fig. 5). The till is mostly silty to sandy in texture (fig. 6). Till thickness ranges from about $100 \mathrm{~m}$ in the lee of some hills and in valleys transverse to ice flow, to a thin veneer or complete absence over the tops of hills. Where stratified sediment is present on hillsides, it is typically not saturated and serves as a recharge area for stratified sediment in valleys, rather than as an aquifer. The wide range of sediment variability and thickness is indicated by the well logs shown in figure 5 of Soller (1993), but most of the area is underlain by a glacial geologic framework of relatively low stratigraphic complexity.

The delineation of coarse-grained, stratified sediment in terrane $1 \mathrm{~A}$ using available geologic maps is problematic, partly because the map scales are too small (that is, regional) to show many of these deposits, especially in valleys within areas of high relief. This problem is illustrated in a comparison of lithologic data (Bayless and others, 2017) with mapping of Quaternary geology (Fullerton and Richmond, variously dated) and stratified-drift aquifers (Kontis and others, 2004, pl. 3) in Vermont and Maine (fig. 29). The Quaternary mapping in Vermont has overstated the width of larger valleys, whereas many smaller valleys are missing from the map (fig. 29A). In addition, some mapped alluvium units are not aligned along valley thalwegs. The larger scale mapping of stratified-drift aquifers (Kontis and others, 2004, pl. 3) more accurately depicts the extents of the valleys in Vermont and also delineates thin eskers in Maine (fig. 29B); however, coarse-grained, stratified sediment identified from lithologic data occurs in areas mapped as unstratified sediment on both maps. These scale-resolution issues are common to all regional-scale mapping. To be consistent and systematic across the map area, in this report the available regional map compilations (for example, Fullerton and Richmond, variously dated) are used rather than attempting to improve the delineation of map units by recompiling a variety of available, more detailed mapping.

Sediment and aquifer characteristics derived from lithologic data in terrane $1 \mathrm{~A}$ are presented herein according to three topographic settings: lowlands, valleys, and uplands. Lithologic logs from the lowlands are located in areas mapped as either lacustrine or marine sediment (fig. 5). Lithologic logs in valleys fall within the stratified-drift aquifer extent from Kontis and others (2004), excluding marine and lacustrine areas from Fullerton and Richmond (variously dated, and contain at least $15 \mathrm{~m}$ of sediment with the uppermost $15 \mathrm{~m}$ composed of more than 50 percent coarse material. The remaining lithologic logs were assigned to uplands. Lithologic data from Maine were omitted from this analysis because the logs were not sufficiently detailed to allow computation of several aquifer metrics.

The median sediment thickness in terrane 1A ranges from $20 \mathrm{~m}$ beneath valleys to $7 \mathrm{~m}$ beneath uplands, although thicknesses of more than $100 \mathrm{~m}$ are in all three areas (fig. 30A). As expected, the percentage of coarse material in valleys (median of 75 percent) is much greater than in uplands or lowlands (fig. 30B). The median percentage of coarse material is 10 percent or less in both uplands and lowlands, but the lowlands have more coarse material than the uplands.

The frequency distribution of material with depth shows that about 80 percent of coarse materials are within 18.5, 21.5, and $23.5 \mathrm{~m}$ of land surface under uplands, lowlands, and valleys, respectively (figs. $30 E-G$ ). High percentages of coarse materials under valleys are within $20 \mathrm{~m}$ of land surface and below a depth of $70 \mathrm{~m}$, whereas the lowest percentages are within the 30- to 60-m depth interval (fig. 30H). This distribution parallels the three facies of stratified sediment commonly in glaciated valleys in the Northeast as described by Randall (2001): early deglacial coarse ice-contact deposits above bedrock, overlain by mid-deglacial, fine lacustrine deposits, which are, in turn, overlain by late-deglacial outwash or alluvium. The highest percentages of coarse material near land surface are characteristic of outwash and alluvium, whereas the lowest percentages of coarse material from 30 to $60 \mathrm{~m}$ reflect the presence of underlying fine lacustrine deposits. The high percentage of coarse material below $70 \mathrm{~m}$ indicates the presence of ice-contact deposits at depth.

The prevalence of aquifer-material intervals penetrated by lithologic logs is greatest in valleys and least in uplands (fig. 31A). Single intervals are most commonly penetrated, although multiple intervals are in some valleys and lowlands. 


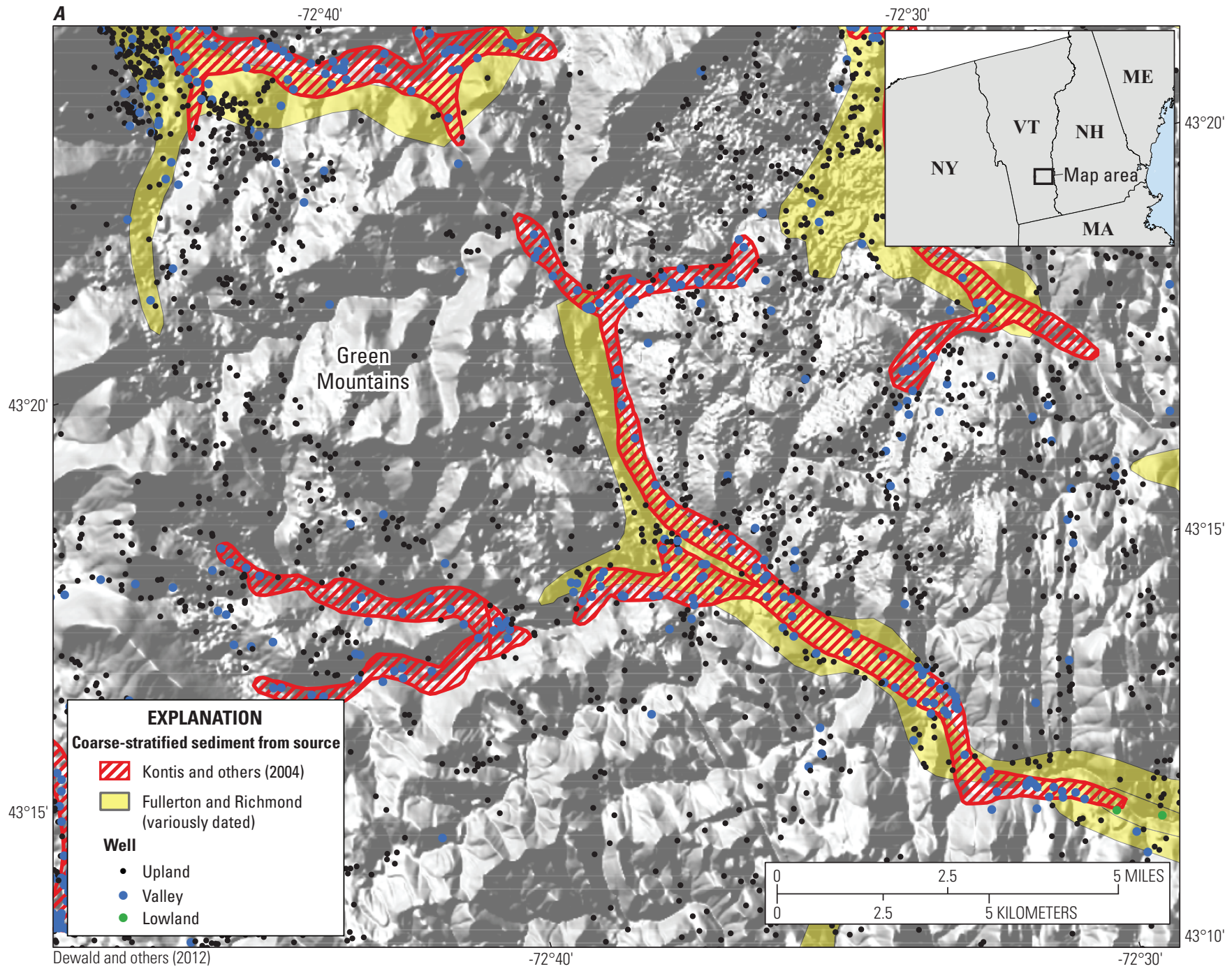

Figure 29. Comparison of extent of coarse-stratified sediment from Kontis and others (2004) and the Glacial Environment and Surficial Sediments geodatabase (Fullerton and Richmond, variously dated). $A$, southeastern Vermont and $B$, central Maine.

Multiple intervals are more common in New York and Ohio (fig. $31 B$ ), where the Wisconsinan ice sheet and multiple glaciations readvanced. Most depths to the aquifer-material intervals in all three topographic settings are less than $10 \mathrm{~m}$; the medians for all settings are zero $\mathrm{m}$, indicating that mostly unconfined conditions exist (fig. 30C). This observation is consistent with ice-contact, outwash, and alluvial sediments at land surface in valley settings and lacustrine sand at land surface in lowland areas. The median thickness of the aquifermaterial intervals (fig. $30 \mathrm{D}$ ) is substantially greater in valleys $(25 \mathrm{~m})$ than in the lowlands $(12 \mathrm{~m})$ and uplands $(8 \mathrm{~m})$. This pattern is consistent with the higher percentages of coarse material in the valley setting.

Most water wells in terrane 1A are completed in bedrock, and the highest percentage of water wells are completed in Quaternary sediments in valleys (fig. 31C). Quaternary water wells are typically unconfined (although the data are skewed by the large numbers of wells in Vermont and Massachusetts), and more wells are confined in uplands and lowlands than in valleys (fig. $31 E$ ). More water wells are completed in Quaternary sediment in Massachusetts, Ohio, and Pennsylvania than in other States in the Northeast (fig. 31D). Quaternary water wells are more likely to be confined in New York and Ohio (fig. $31 F$ ), where areas with more than one aquifer-material interval also are more prevalent.

\section{Terrane 1B-Generally Pre-Late Wisconsinan Sediment in Southern Ohio, Indiana, and Illinois}

Hydrogeologic terrane 1B consists primarily of glacial sediment beyond the Late Wisconsinan ice margin in Ohio, Indiana, and Illinois, and in a small area of Kentucky. Streams in terrane 1B drain upland areas to the Ohio and Mississippi 


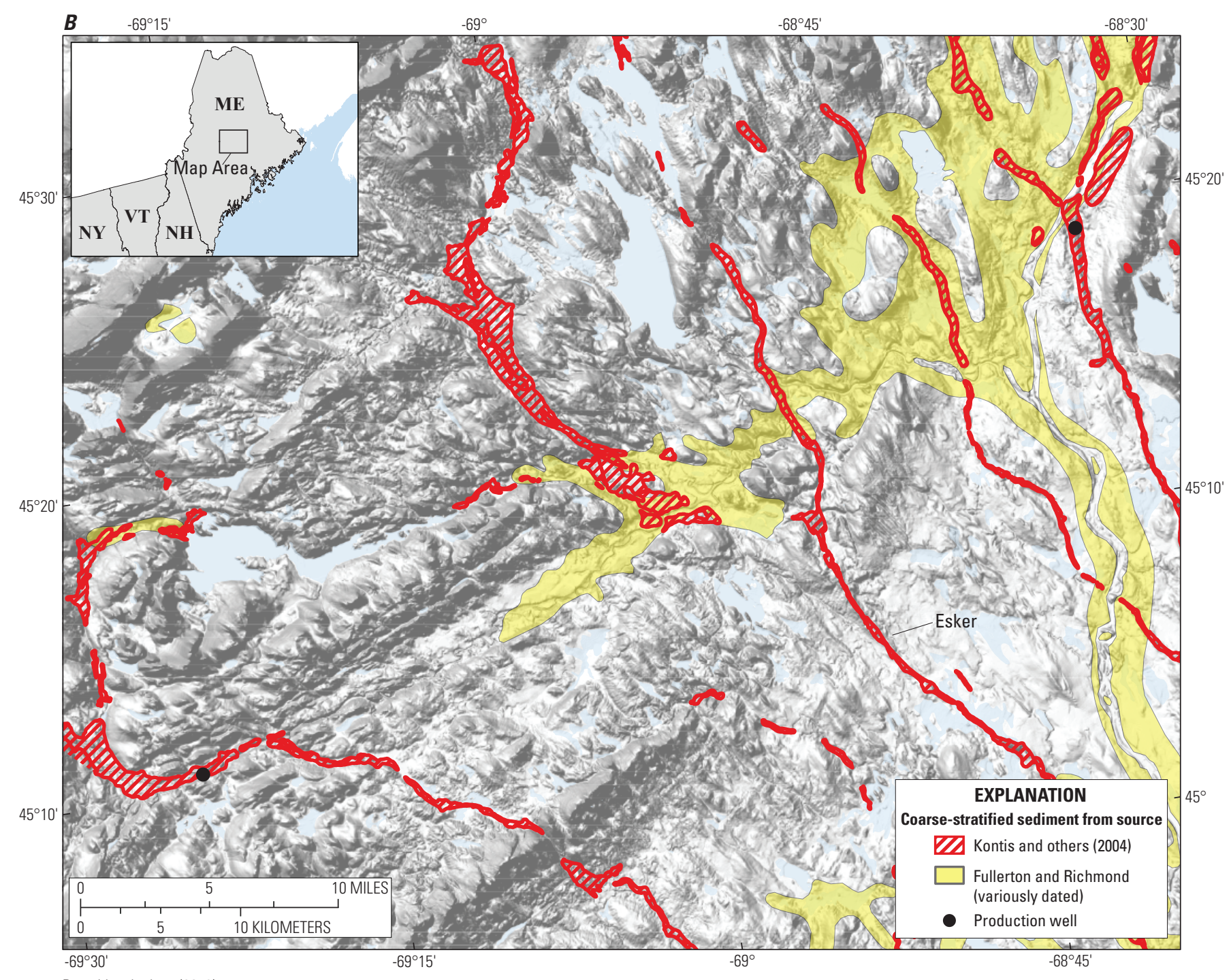

Dewald and others (2012)

Figure 29. Comparison of extent of coarse-stratified sediment from Kontis and others (2004) and the Glacial Environment and Surficial Sediments geodatabase (Fullerton and Richmond, variously dated). $A$, southeastern Vermont and $B$, central Maine.-Continued

Rivers (fig. $2 B$ ). Silty till blankets the uplands and covers about 60 percent of the terrane (figs. 6 and 25), whereas stratified sediment is confined mostly to stream valleys and covers most of the remaining area. Quaternary sediment thins to the south, and sedimentary bedrock is extensively exposed near the limit of glacial ice, which covered the area in Illinoian time. The till in terrane $1 \mathrm{~B}$ is older and more weathered than till in terranes north of the limit of Wisconsinan glaciation, and, therefore, potentially has different hydraulic characteristics. Large areas of colluvium are near the southern limit of the terrane. Terrane 1B also includes substantial areas of mostly Late Wisconsinan stratified sediment — outwash and eolian loess are present in large valleys, such as the Illinois River, Rock River, and Wabash River valleys, and lacustrine sediments are present in tributaries of the Ohio River.

The density of lithologic logs is relatively high in this terrane, especially in Illinois (fig. 8). Median thickness of
Quaternary sediment in lithologic logs ranges from 15 to $30 \mathrm{~m}$ for all map units in this terrane (fig. 32A). The areas of thickest sediment are in certain places where outwash or eolian loess are at land surface. The percentage of coarse material in Quaternary sediments generally is less than 25 percent, except beneath areas where alluvium, eolian loess, or outwash are present at land surface (fig. 32B). The frequency distribution of material with depth shows that about 80 percent of coarse materials are within $24 \mathrm{~m}$ of land surface (figs. $32 E, F$ ). Coarse outwash is especially prevalent in the Illinois River, Rock River, and Wabash River valleys (fig. 12B).

In this terrane, about 25 percent of the lithologic logs penetrated an aquifer-material interval (fig. 28A), mostly in areas of alluvium, eolian loess, or outwash (fig. 32C). Median depths to the aquifer-material intervals are $5 \mathrm{~m}$ or less under these sediments, and deeper ( 8 to $12 \mathrm{~m}$ ) beneath areas where till is at land surface (fig. 32C). Median thickness 

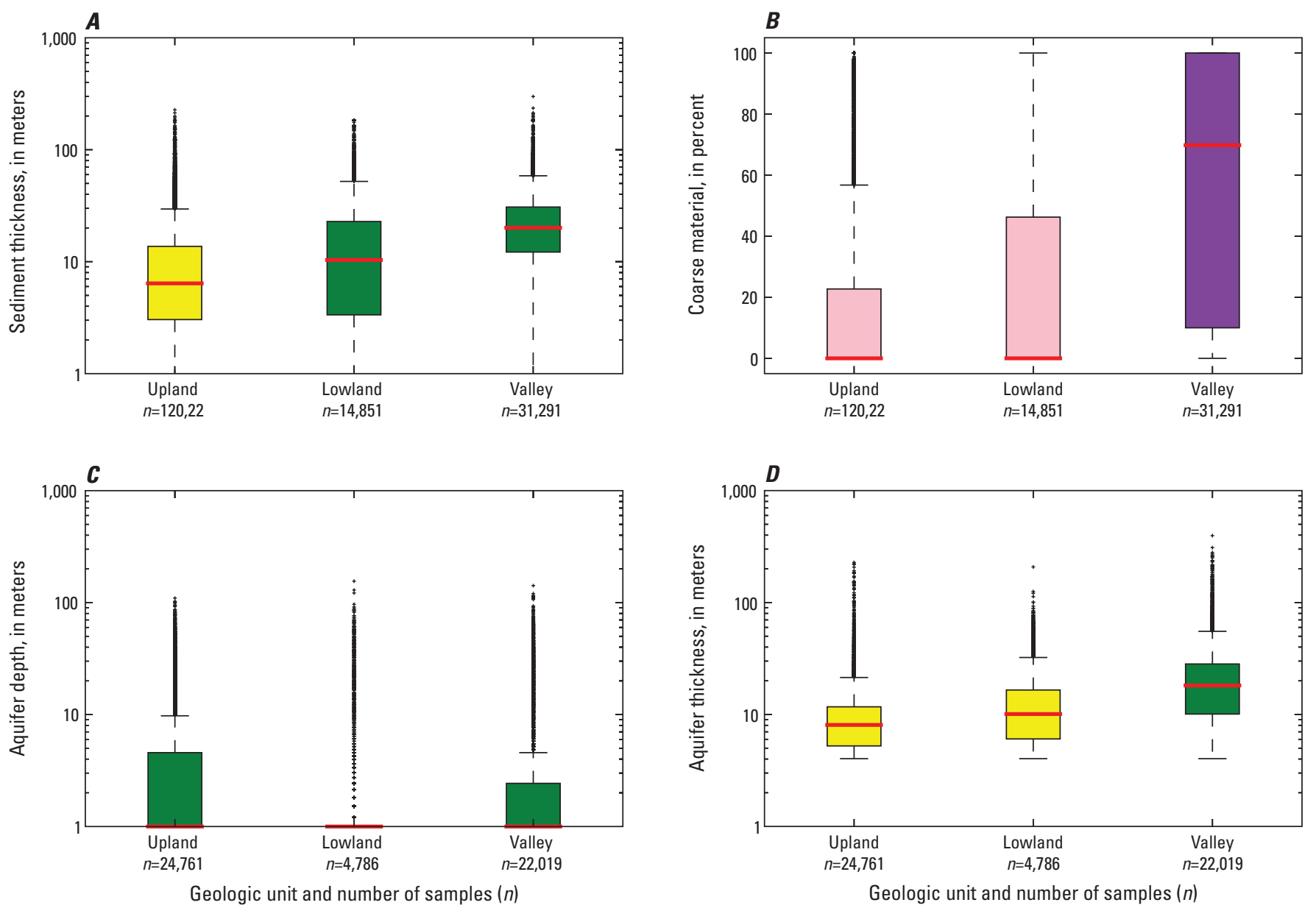

EXPLANATION

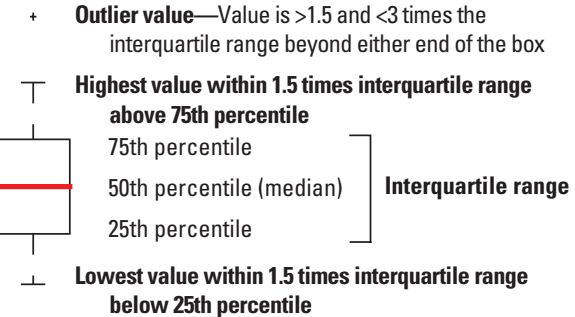

Ratio of group median to median value for all dataFor plots with logarithmic axis, group median is based on log(median)

$<0.5$

$\square \quad 0.5$ to $<1.0$

ए 1.0 to $<1.5$

1.5 to 2.0

$\square>2.0$ below 25 th percentile

Figure 30. $A$, Quaternary thickness, $B$, percent of coarse material, $C$, depth, and $D$, thickness of aquifer-material intervals; frequency distribution of percentages of material beneath $E$, uplands, $F$, lowlands, and $G$, valleys; and $H$, distribution of coarse material with depth by topographic setting in terrane $1 \mathrm{~A}$ in the glaciated conterminous United States. 

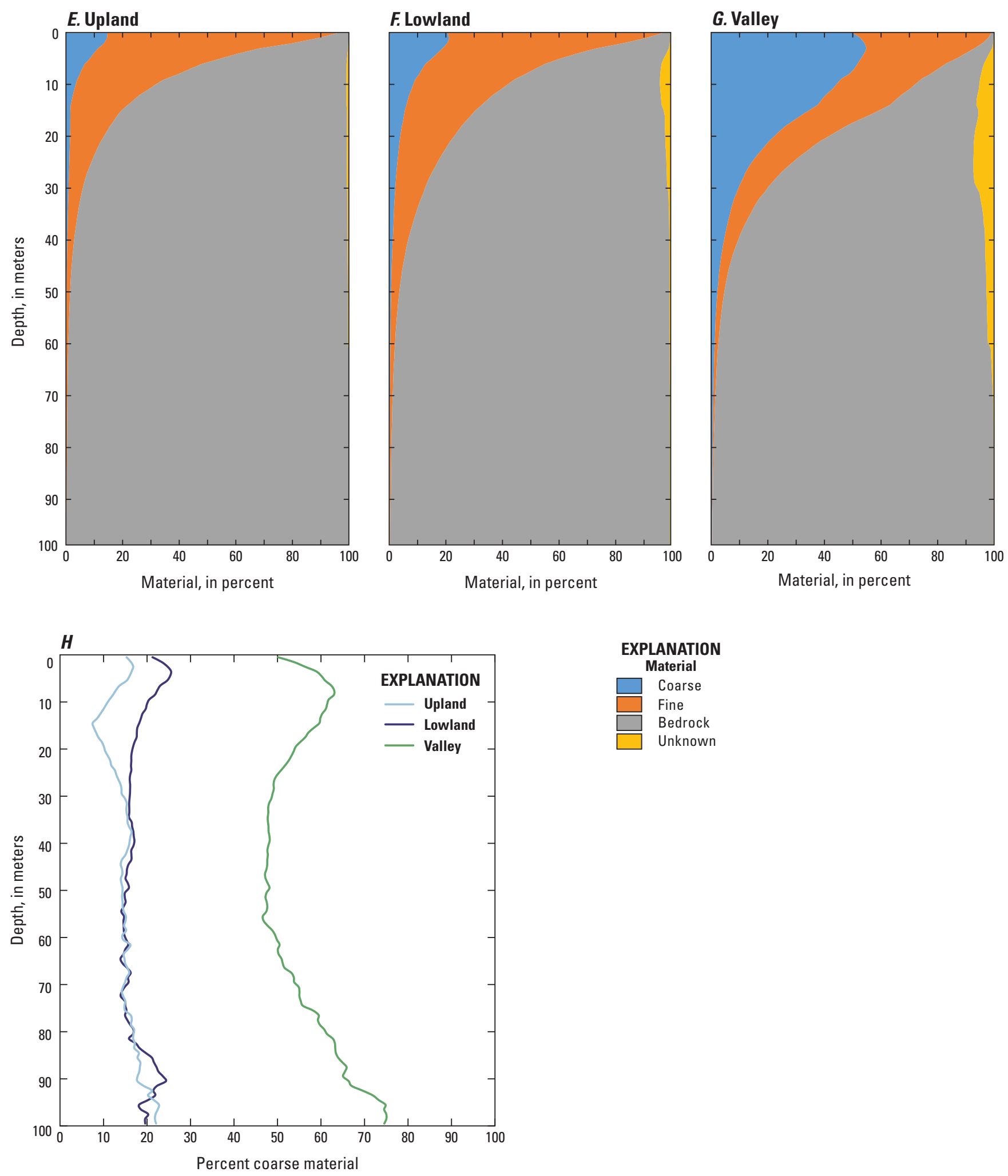

Figure 30. A, Quaternary thickness, $B$, percent of coarse material, $C$, depth, and $D$, thickness of aquifer-material intervals; frequency distribution of percentages of material beneath $E$, uplands, $F$, lowlands, and $G$, valleys; and $H$, distribution of coarse material with depth by topographic setting in terrane $1 A$ in the glaciated conterminous United States. - Continued 

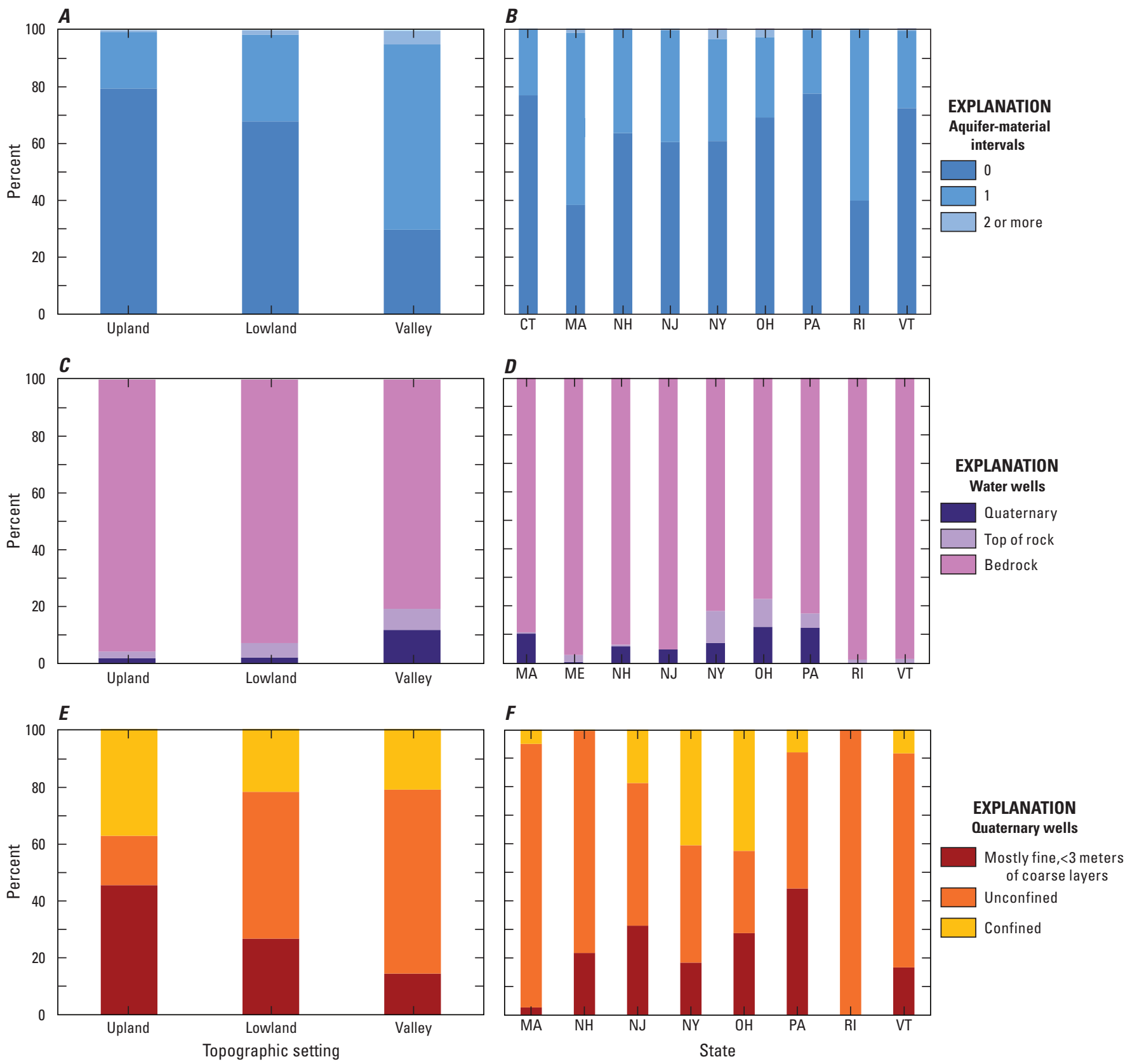

Figure 31. Aquifer characteristics of terrane $1 A$ in the glaciated conterminous United States by topographic setting and State in the glaciated conterminous United States. Number of aquifer-material intervals by $A$, topographic setting and $B$, State; completed water wells in Quaternary sediment and bedrock by $C$, topographic setting and $D$, State; and confined, unconfined, and mostly fine Quaternary water wells by $E$, topographic setting and $F$, State. 

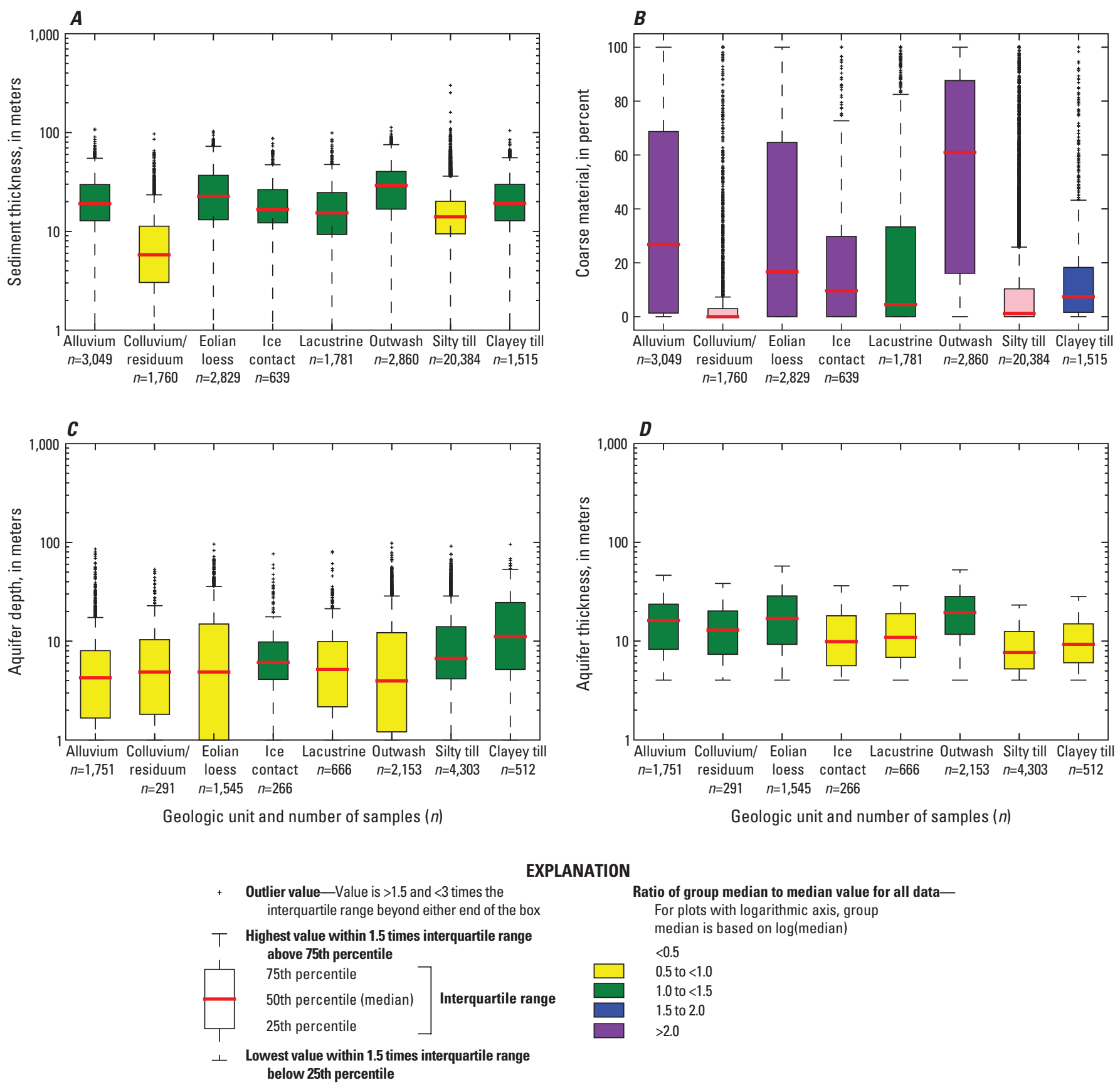

Figure 32. $A$, Quaternary thickness, $B$, percent of coarse material, $C$, depth, and $D$, thickness of aquifer-material intervals; and frequency distribution of percentages of material beneath $E$, coarse-textured and $F$, fine-textured map units grouped by map unit in terrane $1 \mathrm{~B}$ in the glaciated conterminous United States. 

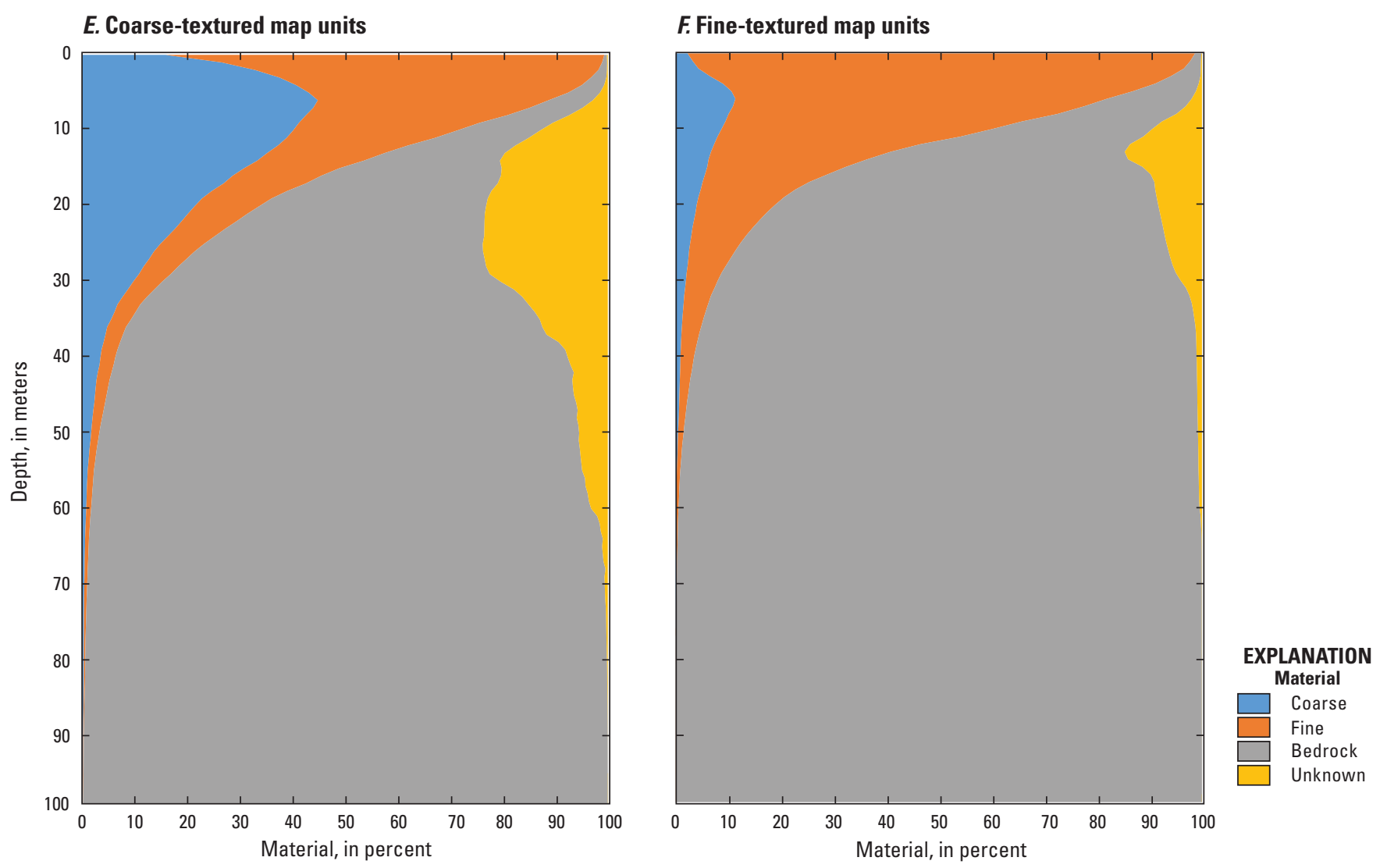

Figure 32. $A$, Quaternary thickness, $B$, percent of coarse material, $C$, depth, and $D$, thickness of aquifer-material intervals; and frequency distribution of percentages of material beneath $E$, coarse-textured and $F$, fine-textured map units grouped by map unit in terrane $1 \mathrm{~B}$ in the glaciated conterminous United States.-Continued

of aquifer-material intervals is greater ( 25 to $35 \mathrm{~m}$ ) under alluvium, eolian loess and outwash, and is less ( 8 to $18 \mathrm{~m}$ ) beneath other types of sediments (fig. 32D). Quaternary water wells are slightly more prevalent than bedrock wells in this terrane (fig. 28B), and more likely to be unconfined than confined (fig. 28C). Thick, unconfined aquifer-material intervals are present in the Illinois River, Rock River, and Wabash River valleys (fig. 20A).

\section{Terrane 1C-Older, Partially Eroded Glacial Sediments in Central Missouri}

Hydrogeologic terrane 1C consists of older (pre-Illinoian) sediment in northern Missouri and northeastern Kansas (fig. 2C). These deposits are highly weathered and eroded and are composed of mostly silty to clayey till that thins to the south. Sedimentary bedrock is extensively exposed near the limit of glacial ice. This terrane also includes areas of Late Wisconsinan and Holocene alluvium in the Missouri River and tributaries. The pre-Illinoian sediment was deposited within the terrane during several periods of glaciation, and the original glacial landforms have been eroded or covered with loess. Till covers about half the terrane (fig. 25), whereas large areas near the Missouri and Mississippi Rivers are covered by colluvial sediments and residual soils. Most of the remaining area is covered by alluvial sediment in valleys draining to these major rivers.

The density of lithologic logs is relatively low in terrane 1C, especially in the central part of Missouri (fig. 8). Median thickness of Quaternary sediment in lithologic logs ranges from 8 to $15 \mathrm{~m}$, except under lacustrine sediments where the median depths is $35 \mathrm{~m}$ (fig. $33 \mathrm{~A}$ ). The median percentage of coarse material in sediment is highest (15 to 18 percent) beneath areas where alluvium or outwash are at land surface, and is near zero throughout the rest of the terrane (fig. 33B). As expected, where coarse-textured, stratified material is present at land surface, the frequency distribution of material with depth indicates that about 80 percent of coarse materials are within $20 \mathrm{~m}$ of land surface (fig. $33 E$ ). About 25 percent of the lithologic logs penetrated an aquifer-material interval in this terrane (fig. 28A), mostly in areas of alluvial, eolian (loess), and outwash sediments. Median depths to aquifer-material intervals (fig. $33 \mathrm{C}$ ) are shallow (6 to $11 \mathrm{~m}$ ) and intervals (fig. $33 D$ ) are thicker beneath areas where alluvium is at land surface $(15 \mathrm{~m})$ than in areas of till $(9 \mathrm{~m})$. Most water wells 

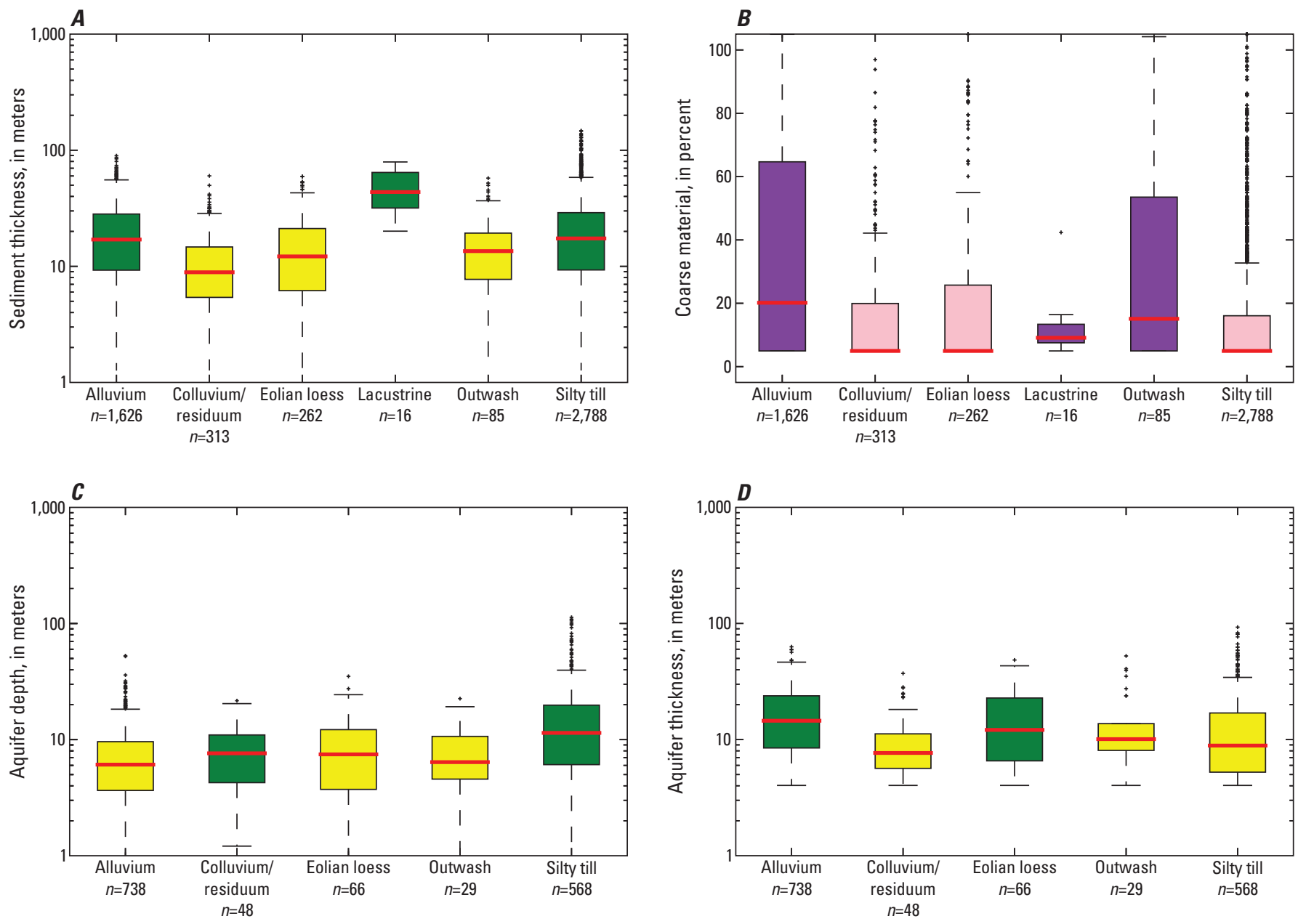

Geologic unit and number of samples $(n)$

Geologic unit and number of samples $(n)$

EXPLANATION

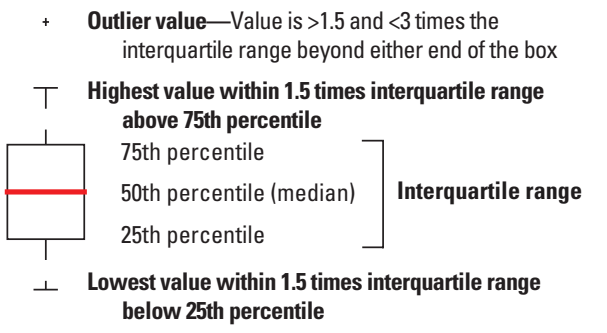

Ratio of group median to median value for all data-

For plots with logarithmic axis, group

median is based on log(median)

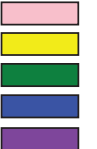

$<0.5$

0.5 to $<1.0$

1.0 to $<1.5$

1.5 to 2.0

$>2.0$

below 25th percentile

Figure 33. $A$, Quaternary thickness, $B$, percent of coarse material, $C$, depth, and $D$, thickness of aquifer-material intervals; and frequency distribution of percentages of material beneath $E$, coarse-textured and $F$, fine-textured map units grouped by map unit in terrane $1 \mathrm{C}$ of the conterminous United States. 


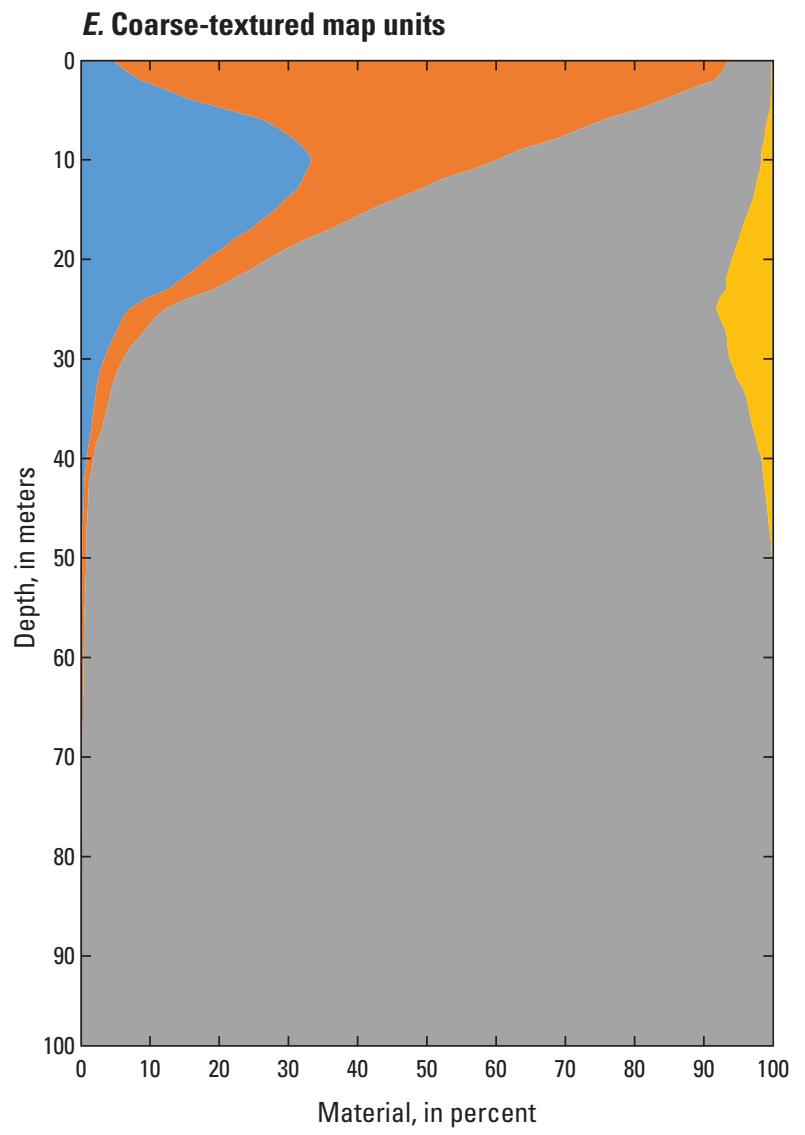

\section{F. Fine-textured map units}

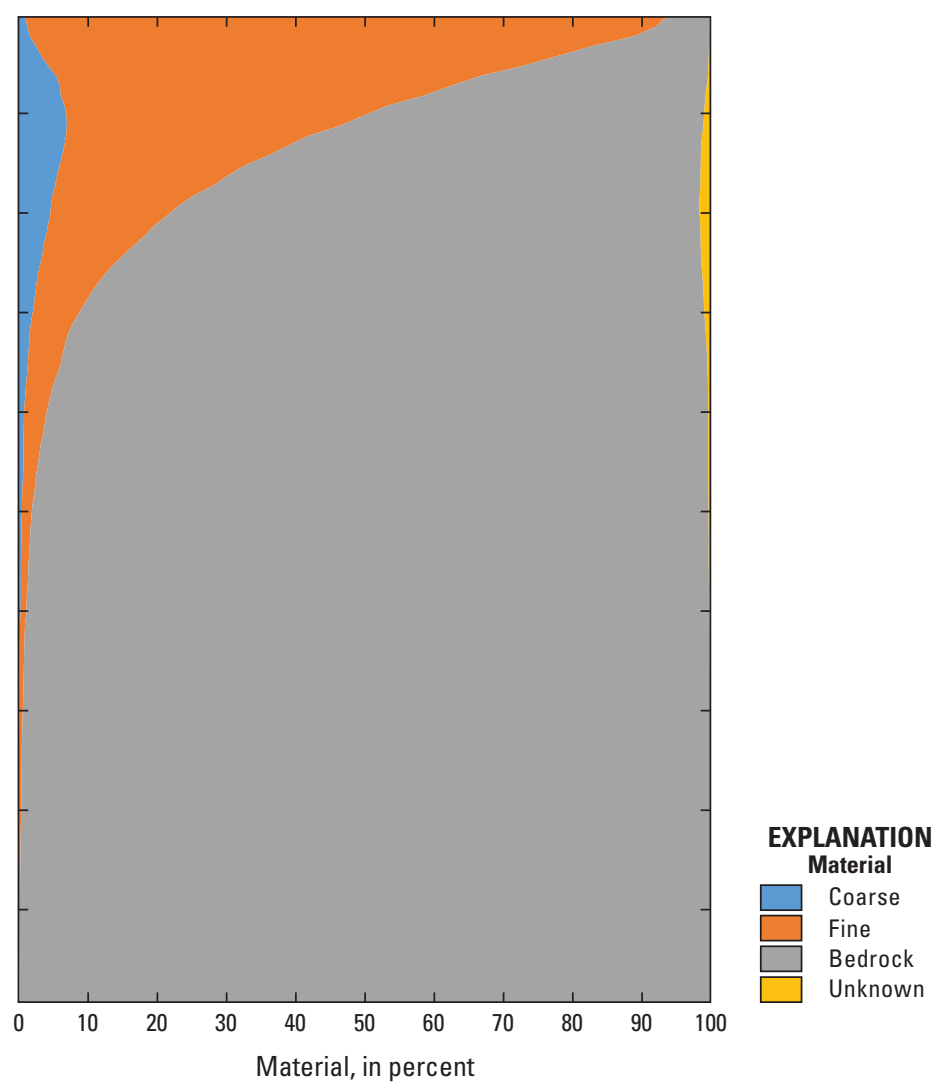

Figure 33. A, Quaternary thickness, $B$, percent of coarse material, $C$, depth, and $D$, thickness of aquifer-material intervals; and frequency distribution of percentages of material beneath $E$, coarse-textured and $F$, fine-textured map units grouped by map unit in terrane $1 \mathrm{C}$ of the conterminous United States.-Continued

are completed in bedrock and only 15 percent are completed in Quaternary sediment (fig. 28B). Wells in the Quaternary sediments are twice as likely to be unconfined than confined (fig. 28C). The highest probability of penetrating an aquifermaterial interval is within the Missouri and Grand River valleys (fig. 14B).

\section{Terrane 1D-Older, Partially Eroded Glacial Sediments Around the Driftless Area}

Hydrogeologic terrane 1D includes the Driftless Area and surrounding glaciated areas in Minnesota, Iowa, Wisconsin, and Illinois (fig. 2D). The Driftless Area is so named because the area was not glaciated during the Pleistocene, although stratified sediment was deposited within that area by meltwater streams that drained the adjacent ice margins. Terrane $1 \mathrm{D}$ is underlain mostly by sedimentary bedrock that is weathered and highly dissected. Within the Driftless Area these rocks are overlain by colluvium (fig. 5). Glacial sediment in the margins surrounding the Driftless Area is mostly silty till, and stratified deposits are most common north and east of the Driftless Area. To the north and east, the boundary is defined as the limit of Late Wisconsinan ice, whereas to the west the boundary roughly coincides with the western edge of the Paleozoic Plateau; there, the till is pre-Late Wisconsinan in age, is extensively eroded, and is patchy with extensive areas of exposed bedrock.

The density of lithologic logs is relatively high in terrane 1D (fig. 8). Median thickness of Quaternary sediment in lithologic logs ranges from 5 to $20 \mathrm{~m}$ and is thickest beneath areas where outwash is at land surface (fig. $34 A$ ). The median percentage of coarse material in sediment (fig. 34B) is highest (greater than 75 percent) beneath areas of outwash and lacustrine sediments, and is near zero throughout the rest of the terrane, with the exception of alluvium (median of 35 percent). The frequency distribution of material with depth indicates that about 80 percent of coarse materials are within $22 \mathrm{~m}$ of land surface beneath coarse-textured, stratified map units (fig. 34E). About 50 percent of the lithologic logs penetrated an aquifer-material interval (fig. 28A), mostly in areas of outwash. Median depths to aquifer-material intervals (fig. 34C) are shallow (less than $3 \mathrm{~m}$ ), except beneath areas of clayey till $(6 \mathrm{~m})$. Median thickness of aquifer-material intervals ranges from 15 to $30 \mathrm{~m}$ (fig. 34D). Most water wells are completed 

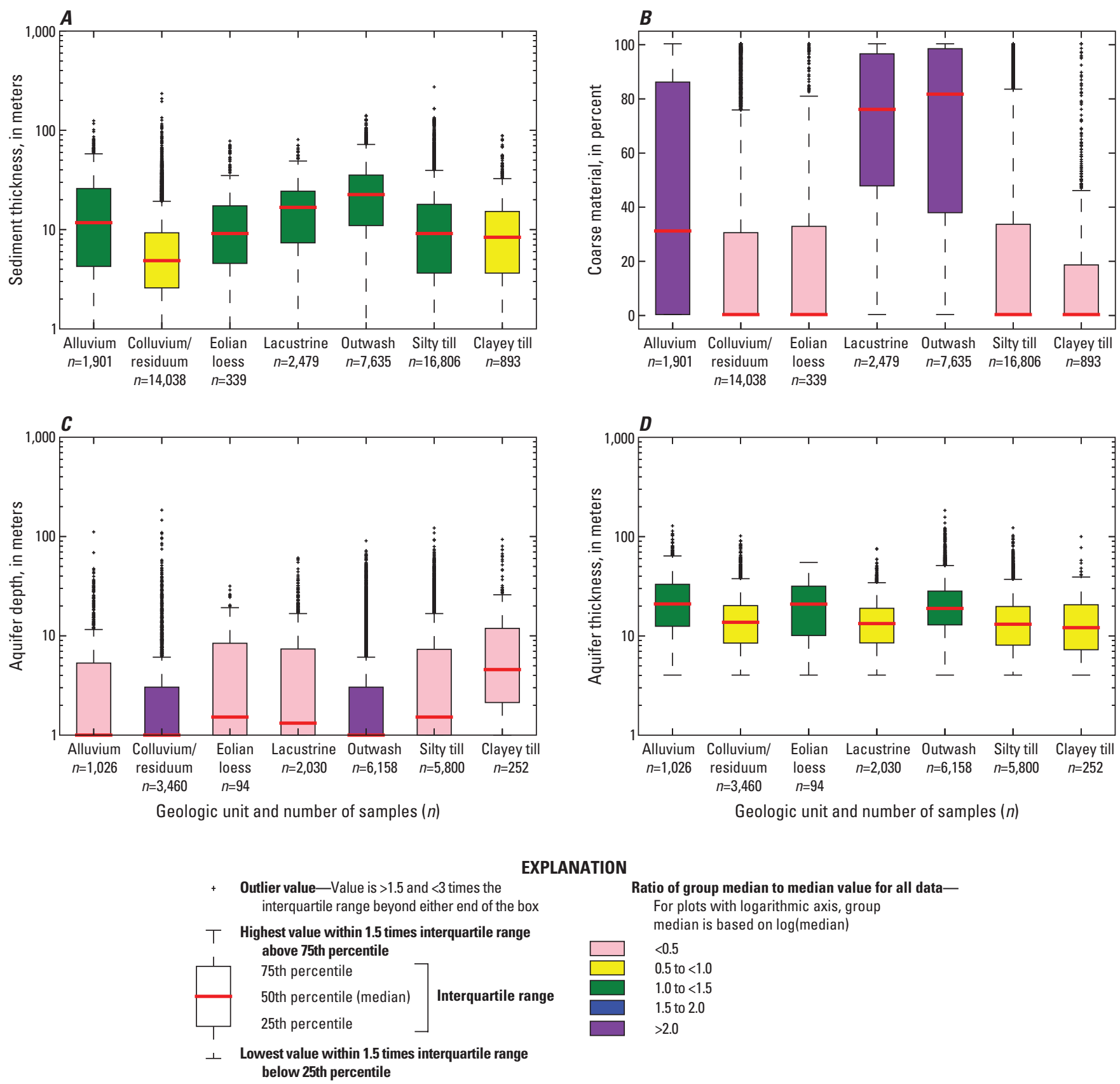

Figure 34. $A$, Quaternary thickness, $B$, percent of coarse material, $C$, depth, and $D$, thickness of aquifer-material intervals; and frequency distribution of percentages of material beneath $E$, coarse-textured and $F$, fine-textured map units grouped by map unit in terrane $1 \mathrm{D}$ in the glaciated conterminous United States. 

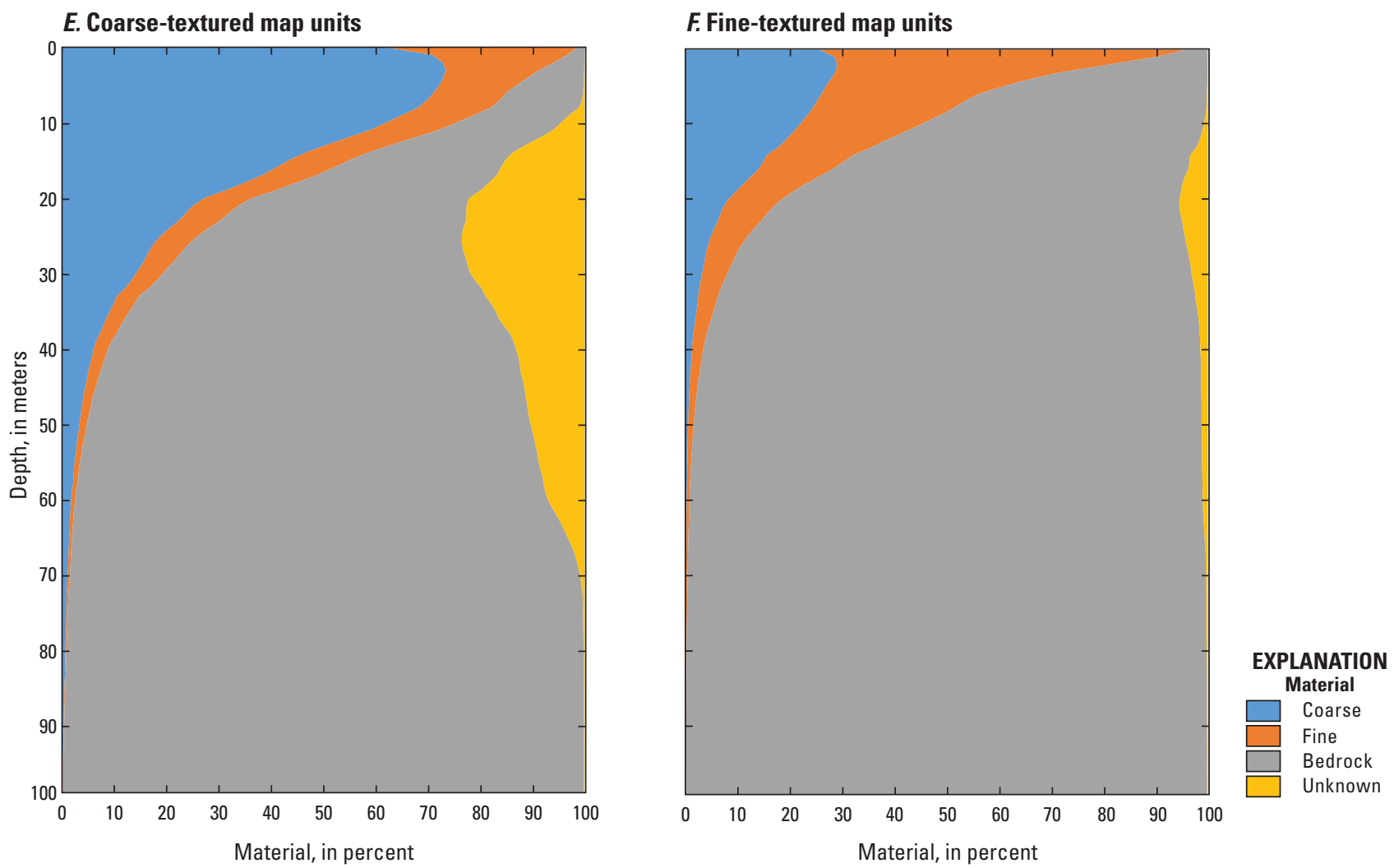

Figure 34. $A$, Quaternary thickness, $B$, percent of coarse material, $C$, depth, and $D$, thickness of aquifer-material intervals; and frequency distribution of percentages of material beneath $E$, coarse-textured and $F$, fine-textured map units grouped by map unit in terrane $1 \mathrm{D}$ in the glaciated conterminous United States. - Continued

in bedrock; only 25 percent are completed in Quaternary sediment (fig. 28B). Wells in Quaternary sediment typically are unconfined (fig. 28C). The highest probability of penetrating an aquifer-material interval is within a narrow band that borders the northern edge of the Driftless Area (fig. 14B).

\section{Terrane 1E-Late Wisconsinan Sediment Near Lakes Superior and Michigan}

Hydrogeologic terrane 1E consists of patchy, Late Wisconsinan sediment on Michigan's Northern Peninsula, on Wisconsin's Door Peninsula, and in northeastern Minnesota (fig. 2D). About 60 percent of this terrane is covered by silty to sandy till (fig. 25) and has extensive areas of organic (peat) and stratified glacial sediment (lacustrine and outwash), especially in Michigan (fig. 5). Quaternary sediments of this terrane mostly overlie sedimentary, igneous (plutonic and volcanic), and metamorphic rocks (fig. 7).

The areal density of lithologic logs is notably inconsistent in this terrane, especially in northeastern Minnesota (fig. 8). Median thickness of Quaternary sediment in lithologic logs ranges from 10 to $20 \mathrm{~m}$, except beneath a few areas of sandy till (fig. 35A). The median percentage of coarse material in sediment is highest beneath areas of outwash and alluvium
(60 and 35 percent, respectively), and is 20 to 25 percent throughout the rest of the terrane, except beneath a few areas of sandy till (fig. 35B). The frequency distribution of material with depth indicates that about 80 percent of coarse materials are within $18 \mathrm{~m}$ of land surface beneath coarse-textured, stratified map units (fig. 35E). About 50 percent of the lithologic logs penetrated an aquifer-material interval (fig. 28A), and median depths are shallow $(1 \mathrm{~m})$, except in areas of clayey till ( $8 \mathrm{~m}$; fig. $35 \mathrm{C}$ ). Median thickness of aquifer-material intervals ranges from 8 to $15 \mathrm{~m}$ (fig. 35D). Most water wells are completed in bedrock, but about 35 percent are completed in Quaternary sediment (fig. 28B). Wells in Quaternary sediment are mostly in unconfined aquifer materials (fig. 28C). The highest probability of penetrating an aquifer-material interval is on Michigan's Upper Peninsula (fig. 14B).

\section{Terrane 1F-Thin Late Wisconsinan Sediment in Montana and North Dakota}

Hydrogeologic terrane 1F consists of mostly thin Late Wisconsinan and some older sediment and exposed sedimentary bedrock in eastern Montana and western North and South Dakota (fig. 2E). On the uplands, this sediment is mostly thin (less than $15 \mathrm{~m}$ ) or patchy, silty till, and fine- to coarse-grained 

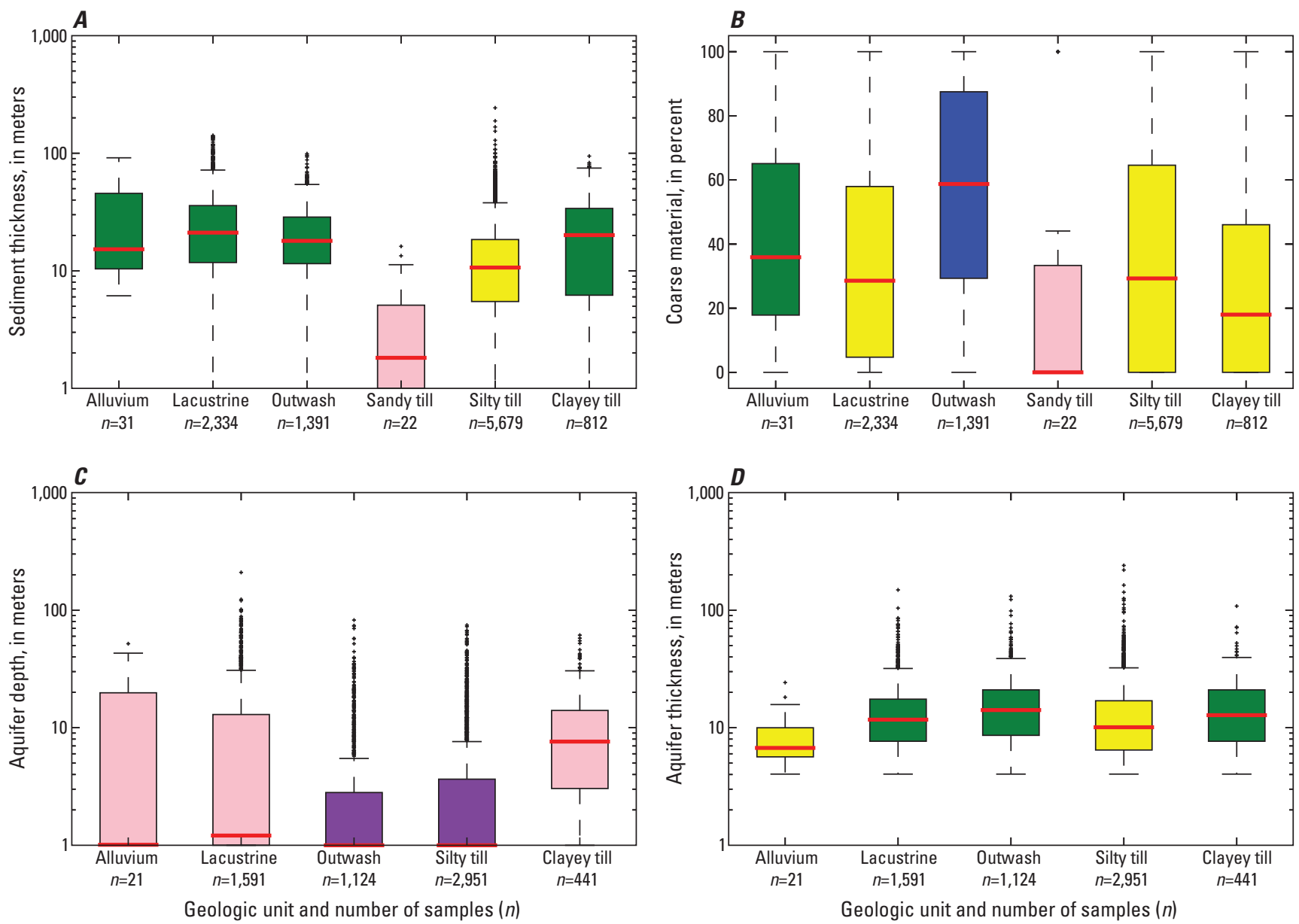

\section{EXPLANATION}

$+\quad$ Outlier value - Value is $>1.5$ and $<3$ times the interquartile range beyond either end of the box

$\top$ Highest value within 1.5 times interquartile range above 75 th percentile

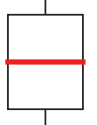

75th percentile

50th percentile (median) Interquartile range

25th percentile

$\perp \quad$ Lowest value within 1.5 times interquartile range below 25th percentile
Ratio of group median to median value for all dataFor plots with logarithmic axis, group median is based on log(median)

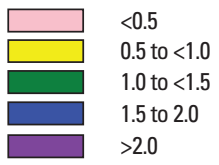

Figure 35. A, Quaternary thickness, $B$, percent of coarse material, $C$, depth, and $D$, thickness of aquifer-material intervals; and frequency distribution of percentages of material beneath $E$, coarse-textured and $F$, fine-textured map units grouped by map unit in terrane $1 \mathrm{E}$ in the glaciated conterminous United States. 

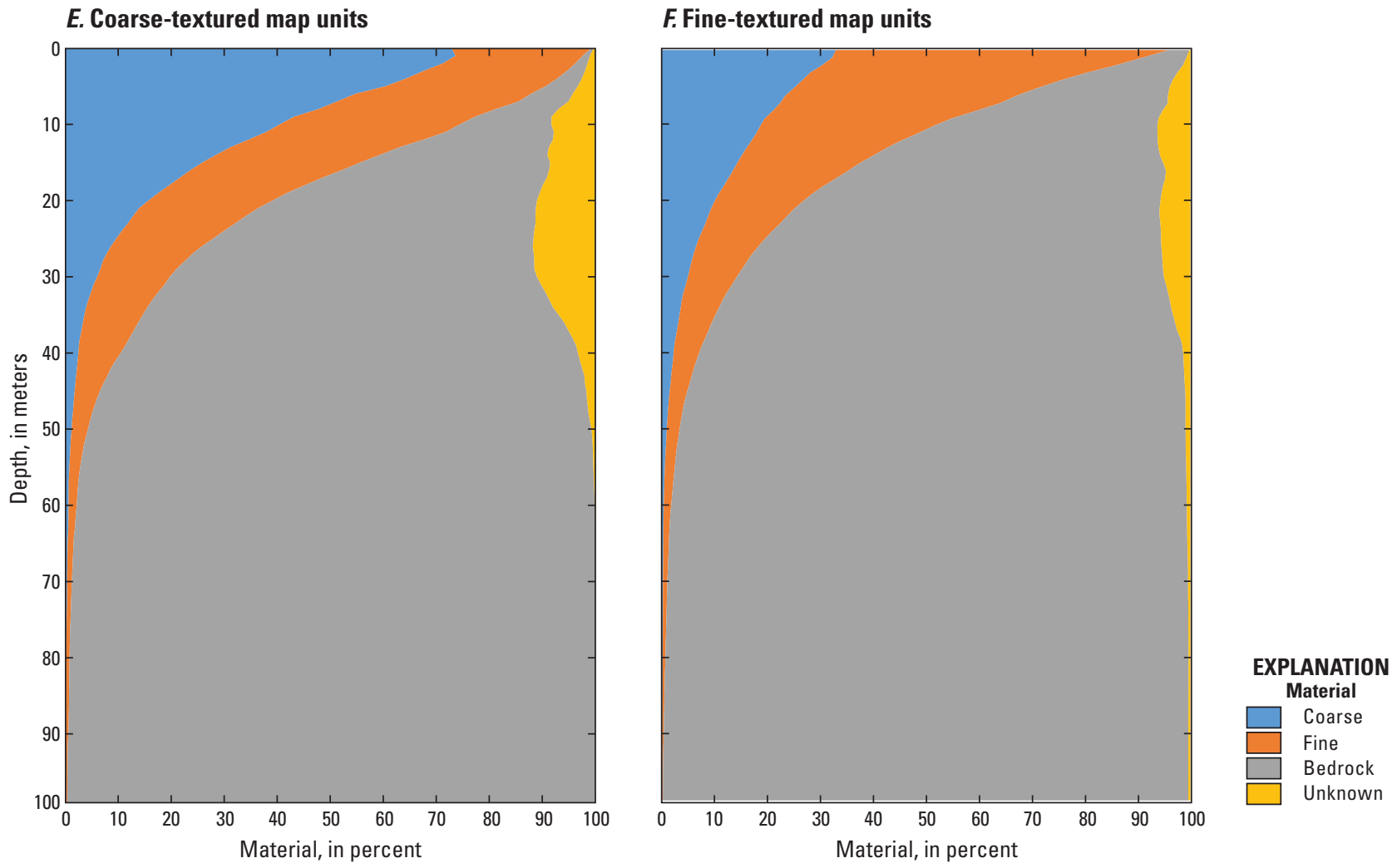

Figure 35. A, Quaternary thickness, $B$, percent of coarse material, $C$, depth, and $D$, thickness of aquifer-material intervals; and frequency distribution of percentages of material beneath $E$, coarse-textured and $F$, fine-textured map units grouped by map unit in terrane $1 \mathrm{E}$ in the glaciated conterminous United States.-Continued

stratified sediment with some till in the Missouri River valley and its tributaries (fig. 5). About 65 percent of the terrane is covered by colluvium (South Dakota) and residuum (Montana and North Dakota). A wide range of sediment variability and thickness is indicated by the well logs shown in Soller (1994, fig. 5), but most of the area is underlain by a glacial geologic framework of relatively low stratigraphic complexity.

The density of lithologic logs in this terrane is relatively low (fig. 8). Median thickness of Quaternary sediment in lithologic logs ranges from 15 to $60 \mathrm{~m}$ and is thickest beneath areas where ice contact sediments are at land surface (fig. 36A). The median percentage of coarse material in sediment is 35 percent beneath alluvium, ice-contact sediment, and outwash, and is less than 20 percent throughout the rest of the terrane (fig. 36B). The frequency distribution of material with depth indicates that, beneath coarse-textured map units, about 80 percent of coarse materials are within $28 \mathrm{~m}$ of land surface (fig. 36E). About 40 percent of the lithologic logs penetrated an aquifer-material interval in this terrane (fig. 28A). Median depths are 5 to $15 \mathrm{~m}$ (fig. 36C) and median thicknesses of aquifer-material intervals are 10 to $15 \mathrm{~m}$ (fig. $36 \mathrm{D}$ ). About 60 percent of water wells are completed in Quaternary sediment (fig. 28B) and are equally likely to be confined or unconfined (fig. 28C).

\section{Terrane $1 \mathrm{G}$-Residuum and Sediment From the Cordilleran Ice Sheet}

Hydrogeologic terrane $1 \mathrm{G}$ extends from the Rocky Mountains in Montana, west to Puget Sound in Washington (fig. $2 F$ ). This broad area is characterized mainly by residuum in mountainous areas and glacial sediments deposited by the Cordilleran ice sheet and alpine glaciers, including patchy till on the uplands and fine- to coarse-grained stratified sediment in the valleys. This terrane is underlain by various types of bedrock, ranging from Archean metamorphic rock in Montana to Tertiary volcanic and sedimentary rock in the Puget Sound lowlands (fig. 7). Quaternary sediments in the lowlands compose the Puget Sound aquifer system and are underlain by Tertiary sediments.

The physiography of this terrane varies considerably and includes high relief in the Cascade and Rocky Mountain ranges, moderate relief in the central Washington Okanogan Highlands, and low relief near Puget Sound. Sediment and aquifer characteristics derived from lithologic data are presented herein according to three topographic settings, analogous to groupings used in terrane 1A: Puget Sound, uplands, and valleys. The Puget Sound setting is defined by the extent of the Puget Sound aquifer system (Vaccaro and others, 1998), 

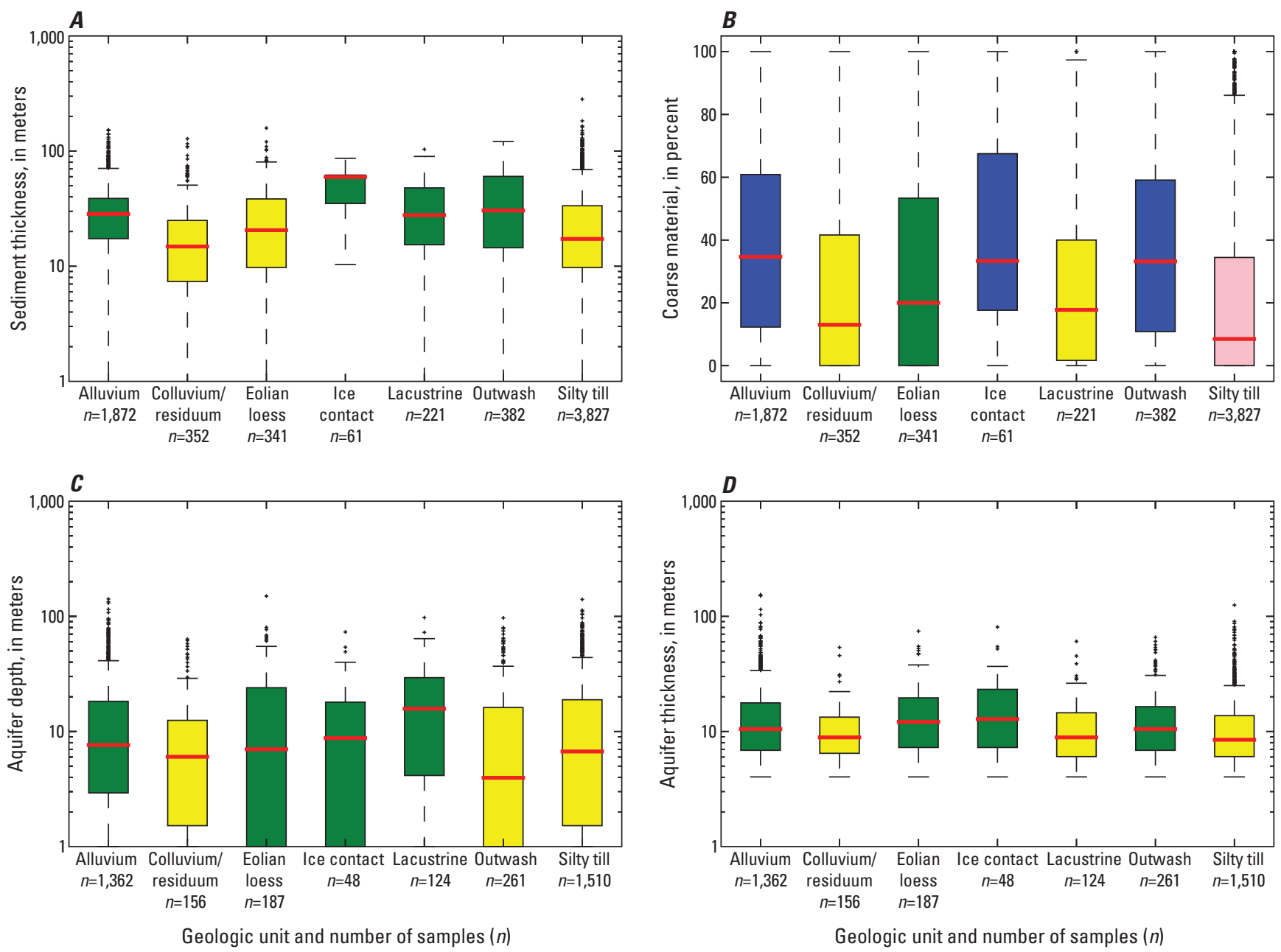

\section{EXPLANATION}

$+\quad$ Outlier value - Value is $>1.5$ and $<3$ times the interquartile range beyond either end of the box

$\top$ Highest value within 1.5 times interquartile range above 75th percentile

75th percentile

50th percentile (median) Interquartile range

25th percentile

$\perp \quad$ Lowest value within 1.5 times interquartile range below 25 th percentile
Ratio of group median to median value for all dataFor plots with logarithmic axis, group median is based on log(median)

$<0.5$

0.5 to $<1.0$

1.0 to $<1.5$

1.5 to 2.0

$>2.0$

Figure 36. $A$, Quaternary thickness, $B$, percent of coarse material, $C$, depth, and $D$, thickness of aquifer-material intervals; and frequency distribution of percentages of material beneath $E$, coarse-textured and $F$, fine-textured map units grouped by map unit in terrane $1 \mathrm{~F}$ in the glaciated conterminous United States. 

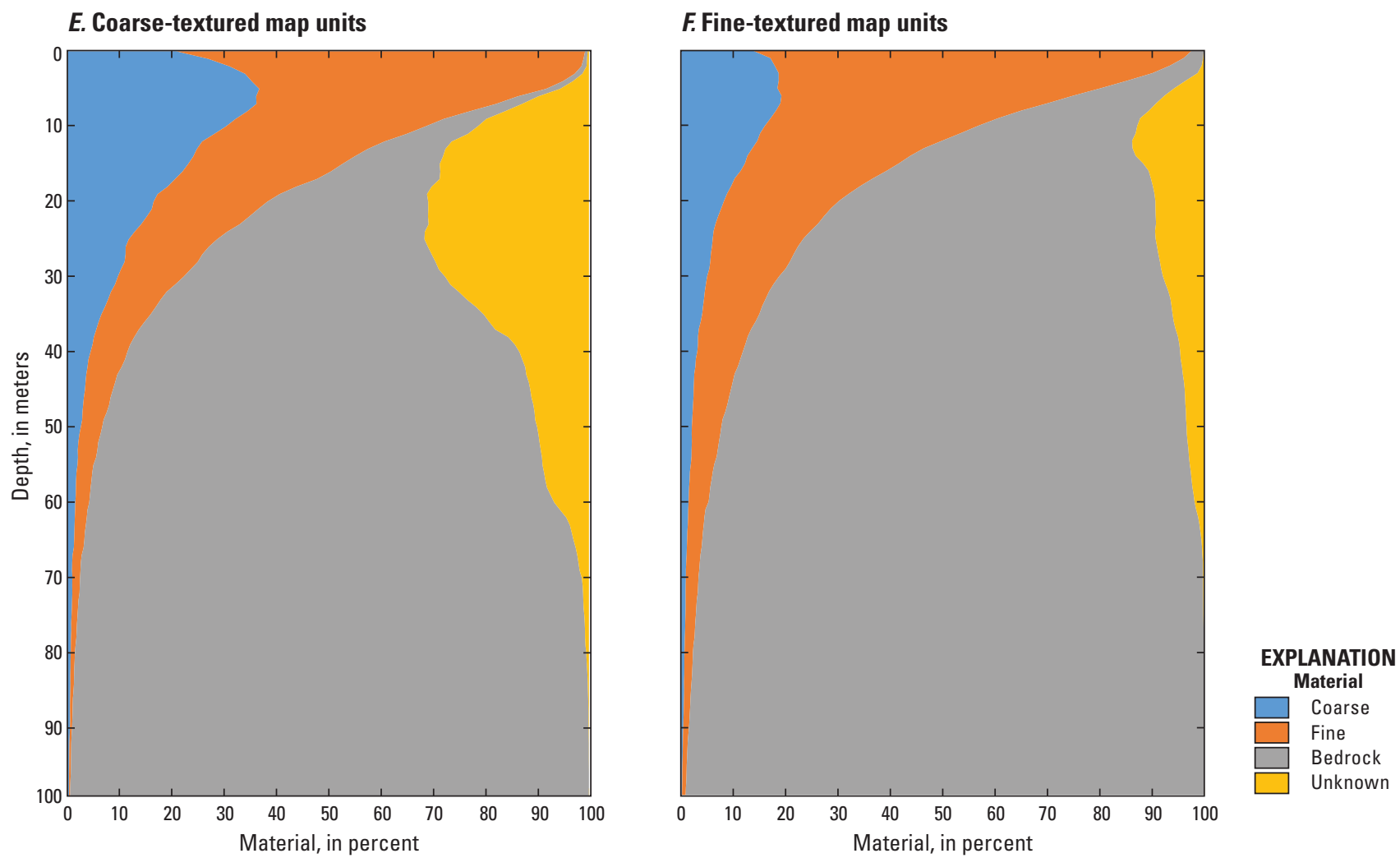

Figure 36. A, Quaternary thickness, $B$, percent of coarse material, $C$, depth, and $D$, thickness of aquifer-material intervals; and frequency distribution of percentages of material beneath $E$, coarse-textured and $F$, fine-textured map units grouped by map unit in terrane $1 \mathrm{~F}$ in the glaciated conterminous United States.-Continued

whereas uplands are associated with areas mapped as residuum. All other areas are grouped as valleys.

The density of lithologic logs in terrane $1 \mathrm{G}$ is generally low, except for Puget Sound and valleys in western Montana (fig. 8). The thickness of Quaternary sediment in many of the valley areas east of Puget Sound is underestimated likely because most of the logs do not penetrate the full thickness of the unconsolidated sediments, and a map of the sediment thickness was not available. Median thickness of Quaternary sediment in lithologic logs ranges from $20 \mathrm{~m}$ in uplands to nearly $200 \mathrm{~m}$ in Puget Sound (fig. 37A). The median percentage of coarse material in sediment is 40 percent in Puget Sound and ranges from 25 to 30 percent throughout the rest of the terrane (fig. $37 B$ ). The frequency distribution of material with depth indicates that about 80 percent of coarse materials are within 50 to $60 \mathrm{~m}$ of land surface beneath the Puget Sound and valleys and within $40 \mathrm{~m}$ of land surface beneath uplands (figs. $37 E-G$ ). Almost 70 percent of the lithologic logs penetrated an aquifer-material interval, and 20 percent of the logs penetrated more than one interval (fig. 28A). Median depths are about $10 \mathrm{~m}$ or less, except in Puget Sound where the median depths are $20 \mathrm{~m}$ (fig. 37C). Median thicknesses of aquifer-material intervals are 15 to $20 \mathrm{~m}$ (fig. 37D). About 65 percent of water wells are completed in Quaternary sediment (fig. 28B) and mostly are confined (fig. 28C).

\section{Hydrogeologic Terranes of Moderate Complexity}

\section{Terrane 2A—Predominantly Late Wisconsinan Sediment, Notably With Buried Valley Systems}

Hydrogeologic terrane 2A consists of a nearly continuous cover of Quaternary sediment that overlies sedimentary bedrock, and extends from Wisconsin, through Illinois, Indiana, and Ohio, and into Michigan (fig. 2B). Silty till predominates on the uplands and covers 70 percent of the terrane (fig. 25). Stratified sediment is mostly confined to stream valleys, except along the shores of Lakes Michigan, Erie, and Huron, where broad areas of pro-glacial lacustrine sediments cover 15 percent of the terrane (fig. 5). Clayey till occupies lowlands southwest of Lakes Michigan and Erie (fig. 6), which are remnants of advances of the Michigan and Huron-Erie ice lobes. A succession of end moraines in Illinois, Indiana, and Ohio mark positions where these lobes stalled during the glacial retreat (fig. 5). Most of this terrane is underlain by carbonate bedrock (fig. 7); bedrock aquifers are hydraulically connected to Quaternary aquifers, especially in eastern Indiana and western Ohio, where together they are treated as a single aquifer system (Eberts and George, 2000). 

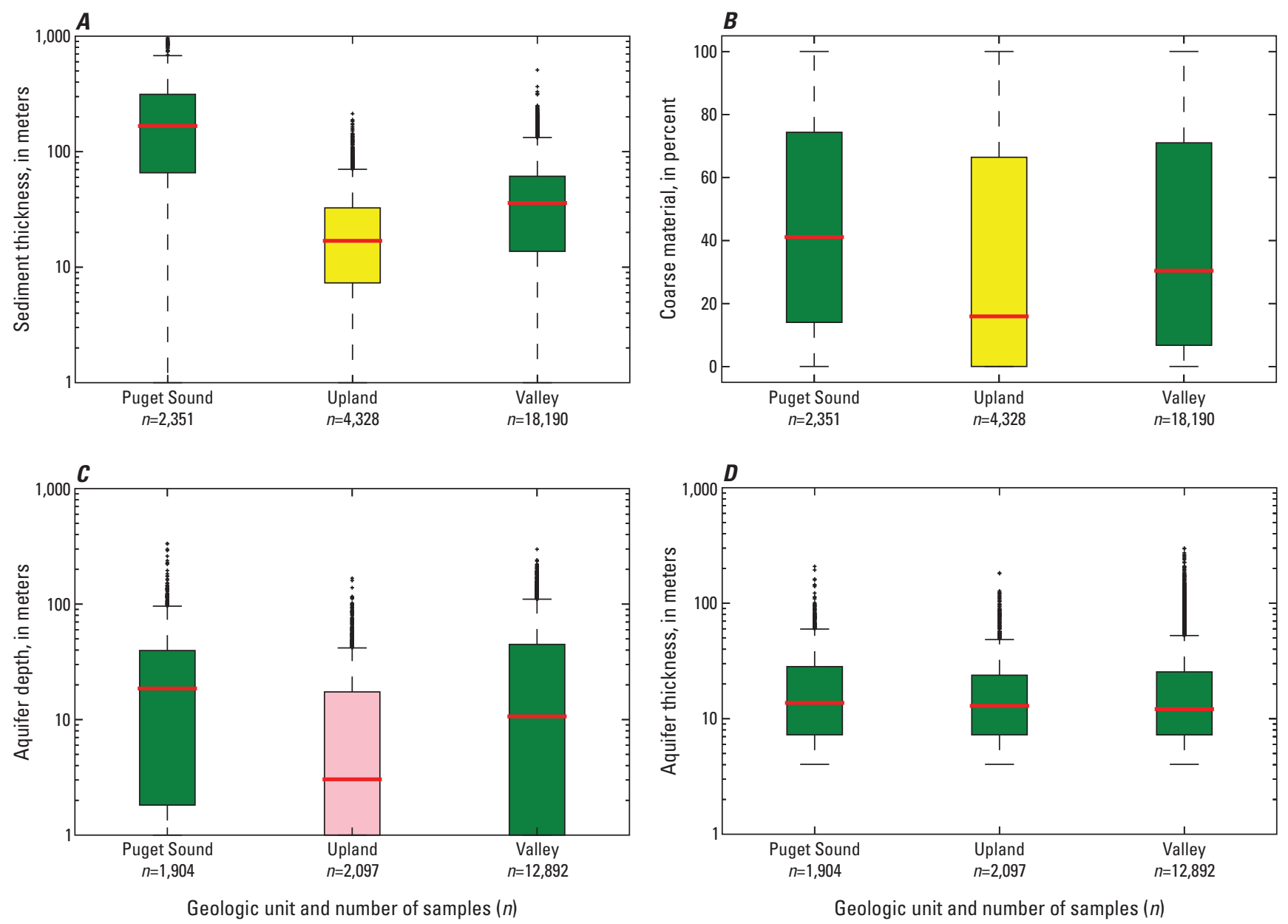

Geologic unit and number of samples $(n)$

\section{EXPLANATION}
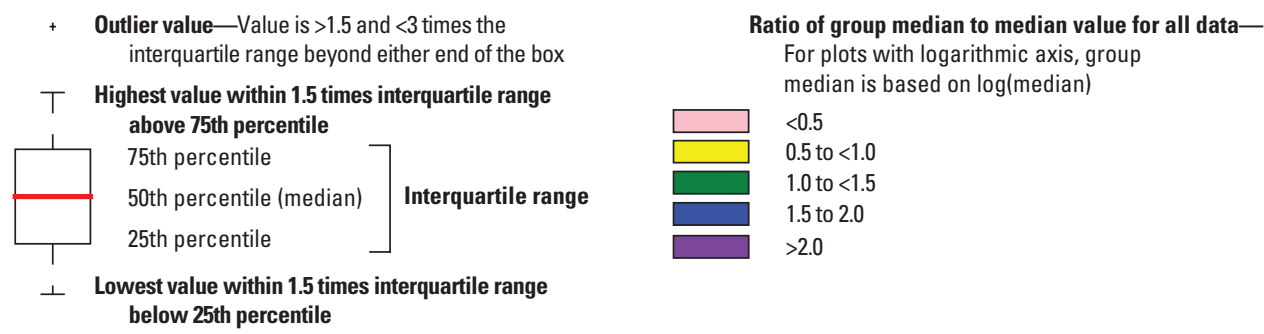

below 25th percentile

Figure 37. $A$, Quaternary thickness, $B$, percent of coarse material, $C$, depth, and $D$, thickness of aquifer-material intervals; and frequency distribution of percentages of material beneath $E$, Puget Sound, $F$, uplands, and $G$, valleys grouped by topography in terrane $1 \mathrm{G}$ in the glaciated conterminous United States. 

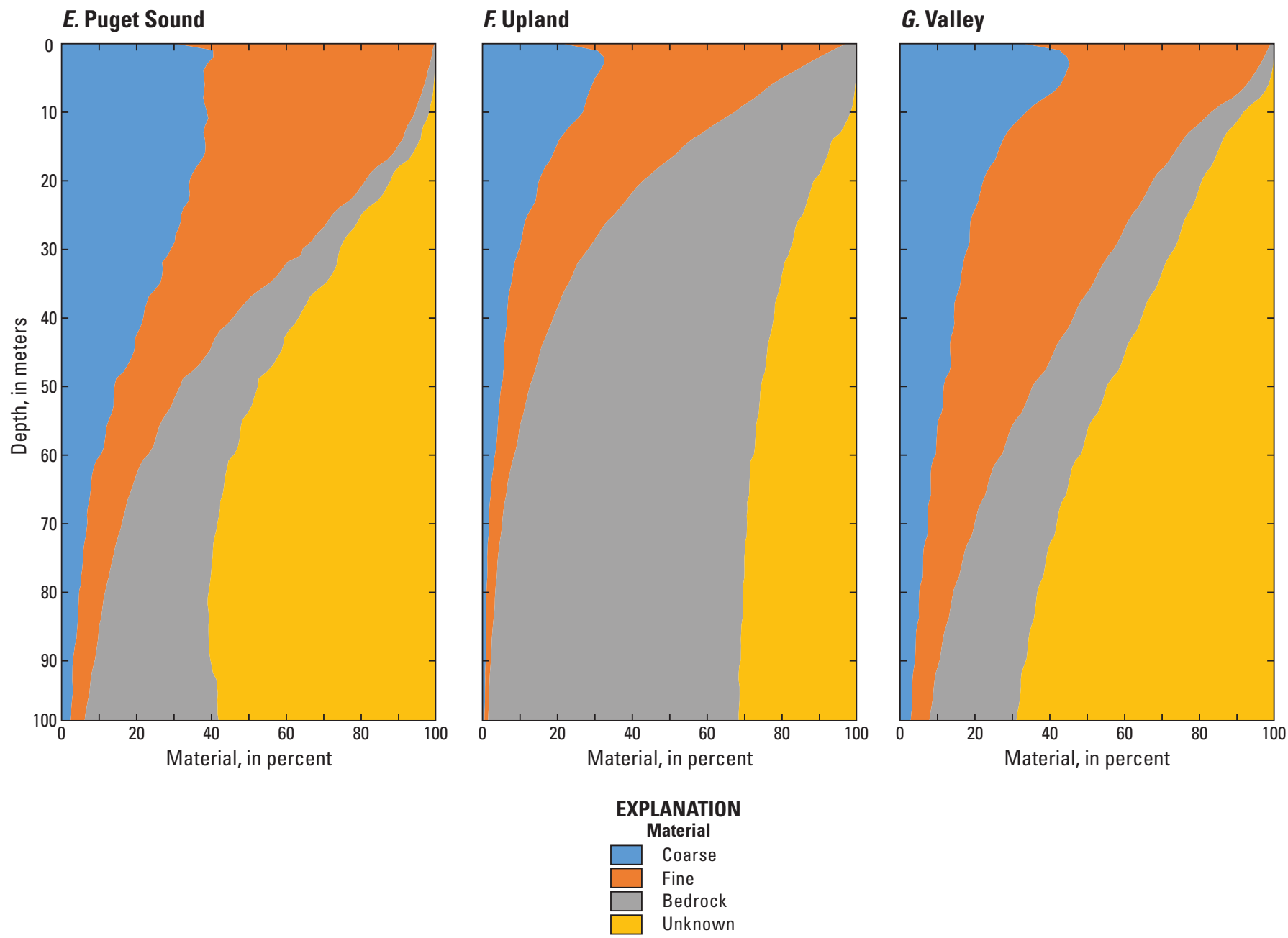

Figure 37. A, Quaternary thickness, $B$, percent of coarse material, $C$, depth, and $D$, thickness of aquifer-material intervals; and frequency distribution of percentages of material beneath $E$, Puget Sound, $F$, uplands, and $G$, valleys grouped by topography in terrane $1 \mathrm{G}$ in the glaciated conterminous United States.-Continued

Quaternary sediment at land surface is almost entirely of Late Wisconsinan age; Illinoian and older glacial sediments are preserved at depth (for example, within the MahometLafayette (Teays) buried-valley aquifer system of Ohio, Indiana, and Illinois) and over other bedrock topographic lows. The variability of sediment texture and lithostratigraphy, and the range of hydrogeologic characteristics, is relatively higher than for lower complexity terranes described in previous sections. The example well logs in Soller (1998), especially for Illinois and Indiana, give some indication of this variability at depth. The southern limit of this terrane is defined as the farthest extent of Late Wisconsinan glaciation. The eastern and northern boundaries are relatively arbitrary.

The density of lithologic logs in this terrane is relatively high (fig. 8). Median thickness of Quaternary sediment in lithologic logs ranges from 20 to $40 \mathrm{~m}$ (fig. 38A). Sediment thickness is greatest over buried valleys in Illinois, Indiana and Ohio (fig. 12A). The median percentage of coarse material in sediment is 35 to 40 percent beneath areas where stratified sediment (alluvium, ice contact and outwash) is at land surface and is less than 15 percent throughout the rest of the terrane (fig. 38B). The frequency distribution of material with depth indicates that, beneath coarse-textured map units, about 80 percent of coarse materials are within $26 \mathrm{~m}$ of land surface (fig. 38E). About 40 percent of the lithologic logs penetrated an aquifer-material interval (fig. 28A), and multiple intervals were penetrated in 10 percent of the logs. Median depths to aquifer-material intervals penetrated in logs in areas of stratified sediment are 5 to $8 \mathrm{~m}$ (fig. 38C) and deeper ( 15 to $20 \mathrm{~m}$ ) in areas covered by till. Median thickness of aquifer-material intervals ranged from 10 to $15 \mathrm{~m}$ (fig. 38D). About 45 percent of water wells are completed in Quaternary sediment (fig. 28B) and are more likely to be confined than unconfined (fig. 28C). Aquifer-material intervals are reliably present in buried valleys of Illinois and Indiana, where they are likely to be confined, and in outwash south of 
$\boldsymbol{A}$

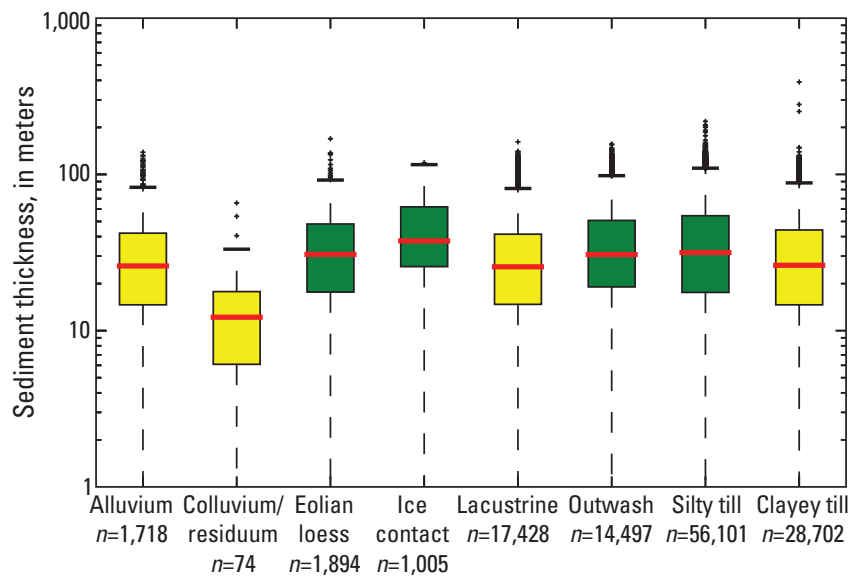

C

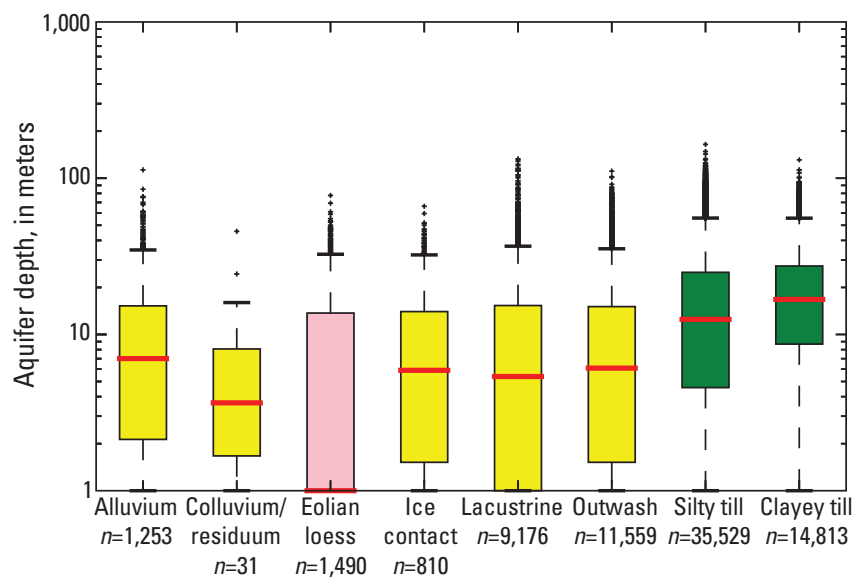

Geologic unit and number of samples $(n)$
B

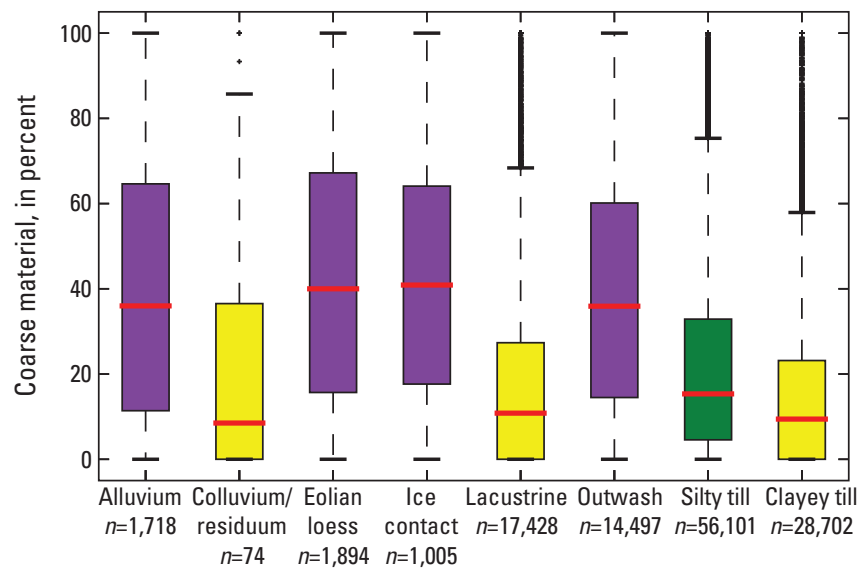

D

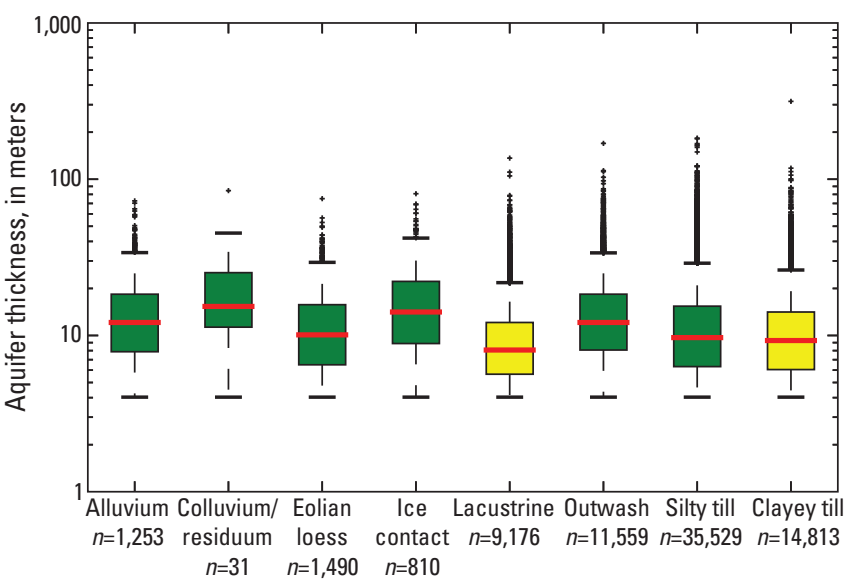

Geologic unit and number of samples $(n)$

\section{EXPLANATION}
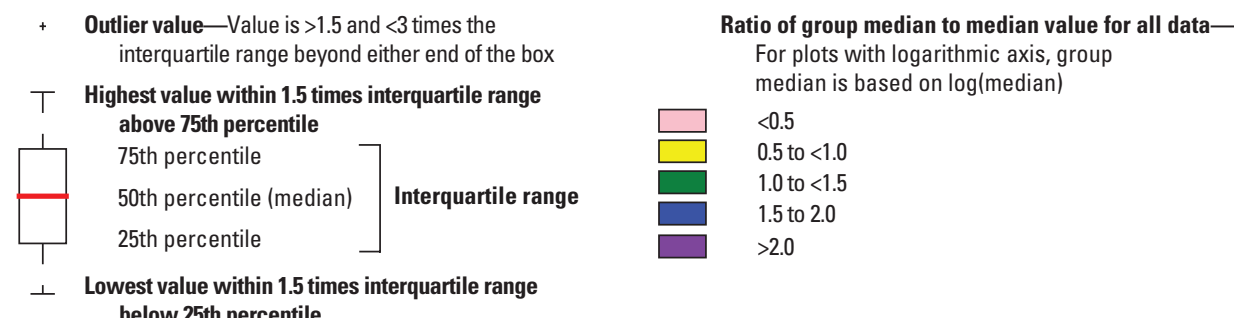
below 25th percentile

Figure 38. $A$, Quaternary thickness, $B$, percent of coarse material, $C$, depth, and $D$, thickness of aquifer-material intervals; and frequency distribution of percentages of material beneath $E$, coarse-textured and $F$, fine-textured map units grouped by map unit in terrane $2 \mathrm{~A}$ in the glaciated conterminous United States. 

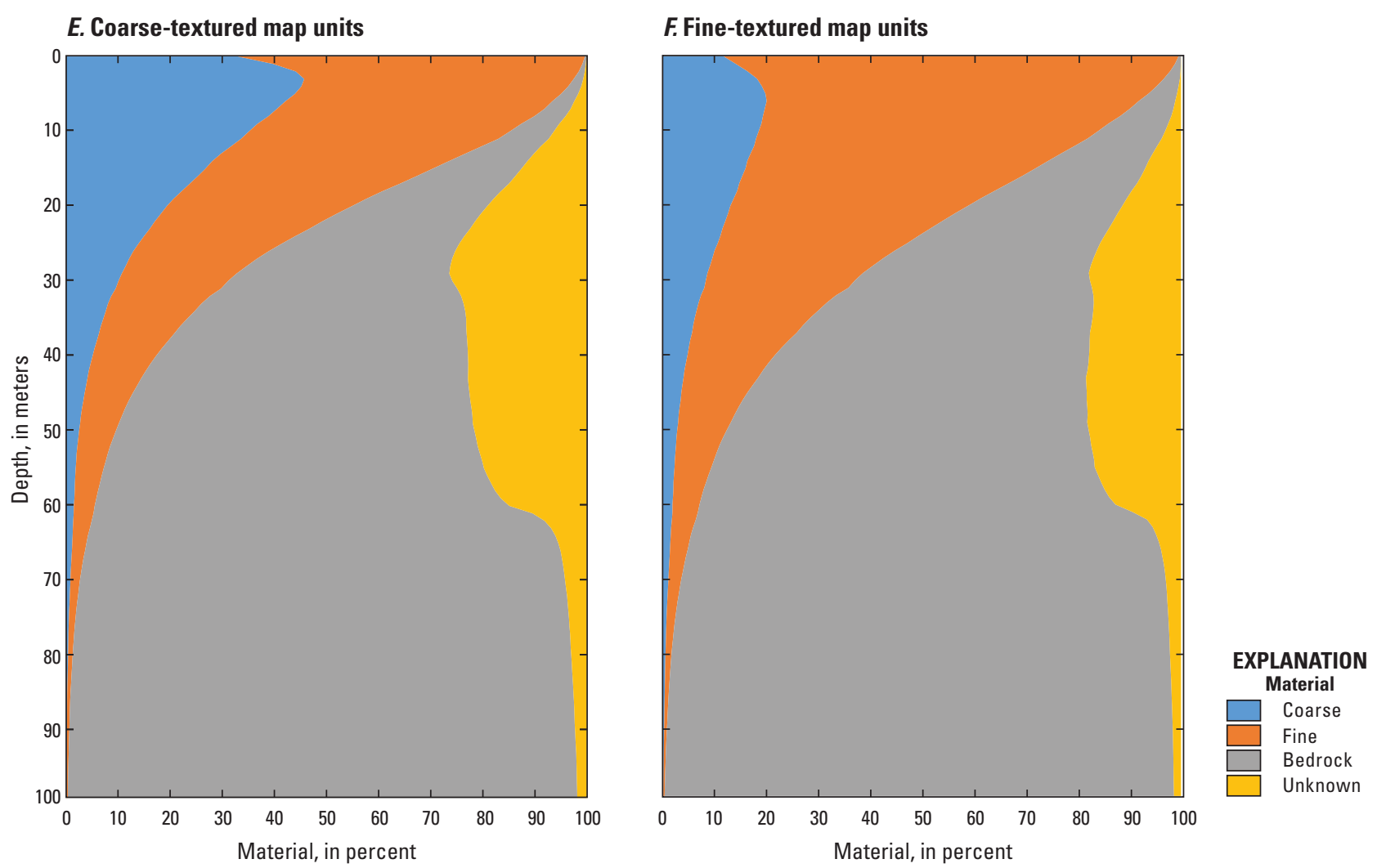

Figure 38. $A$, Quaternary thickness, $B$, percent of coarse material, $C$, depth, and $D$, thickness of aquifer-material intervals; and frequency distribution of percentages of material beneath $E$, coarse-textured and $F$, fine-textured map units grouped by map unit in terrane $2 \mathrm{~A}$ in the glaciated conterminous United States.-Continued

Lake Michigan and southwest of Saginaw Bay, where they are likely to be unconfined (figs. 14 and 20B). The MahometLafayette aquifer system in Illinois is an example of a buried Quaternary aquifer occupying a bedrock valley; it is used extensively for public-water supply (Herzog and others, 2003; Roadcap and others, 2011).

\section{Terrane 2B — Late Wisconsinan Sediment From Lake Superior Lobe}

Hydrogeologic terrane $2 \mathrm{~B}$ consists of a nearly continuous cover of mostly Late Wisconsinan sediment deposited by the Lake Superior lobe over sedimentary, igneous (plutonic and volcanic), and metamorphic rocks in northern Wisconsin and eastern Minnesota (figs. $2 D$ and 7). Silty to sandy till covers 55 percent of the terrane (fig. 25). The remainder is covered by an extensive area of coarse-grained, stratified sediment, primarily in the eastern part of the terrane and southwest of Lake Superior (fig. 12B). The example well logs in Soller (1998) for Wisconsin convey the level of complexity of deposits in this terrane. The southern limit of the terrane is defined as the farthest extent of Late Wisconsinan glaciation. Other boundaries of this terrane are relatively arbitrary.
The density of lithologic logs in this terrane is relatively high (fig. 8). Median thickness of Quaternary sediment in lithologic logs ranges from 20 to $50 \mathrm{~m}$ and is thickest beneath areas of lacustrine sediments and clayey till (fig. 39A). The median percentage of coarse material in sediment is 65 to 90 percent beneath areas where alluvium, ice-contact sediments, or outwash are at land surface and is 15 to 40 percent beneath other map units (fig. 39B). The frequency distribution of material with depth indicates that, beneath coarse-textured map units, about 80 percent of coarse materials are within $20 \mathrm{~m}$ of land surface (fig. 39E). About 60 percent of the lithologic logs penetrated an aquifer-material interval (fig. 28A), and multiple intervals were penetrated in 17 percent of the logs. Median depths to aquifer-material intervals in areas of stratified sediment are less than $4 \mathrm{~m}$ (fig. 39C) and are deeper (10 to $20 \mathrm{~m}$ ) beneath areas covered by lacustrine sediments and clayey till. Median thickness of aquifer-material intervals ranged from 15 to $25 \mathrm{~m}$ (fig. 39D). About 70 percent of water wells are completed in Quaternary sediment (fig. 28B), and are twice as likely to be unconfined as confined (fig. 28C). The probability of penetrating an aquifer-material interval is high in this terrane, and thick deposits of unconfined aquifer material extend through most of this area (fig. 20A). 

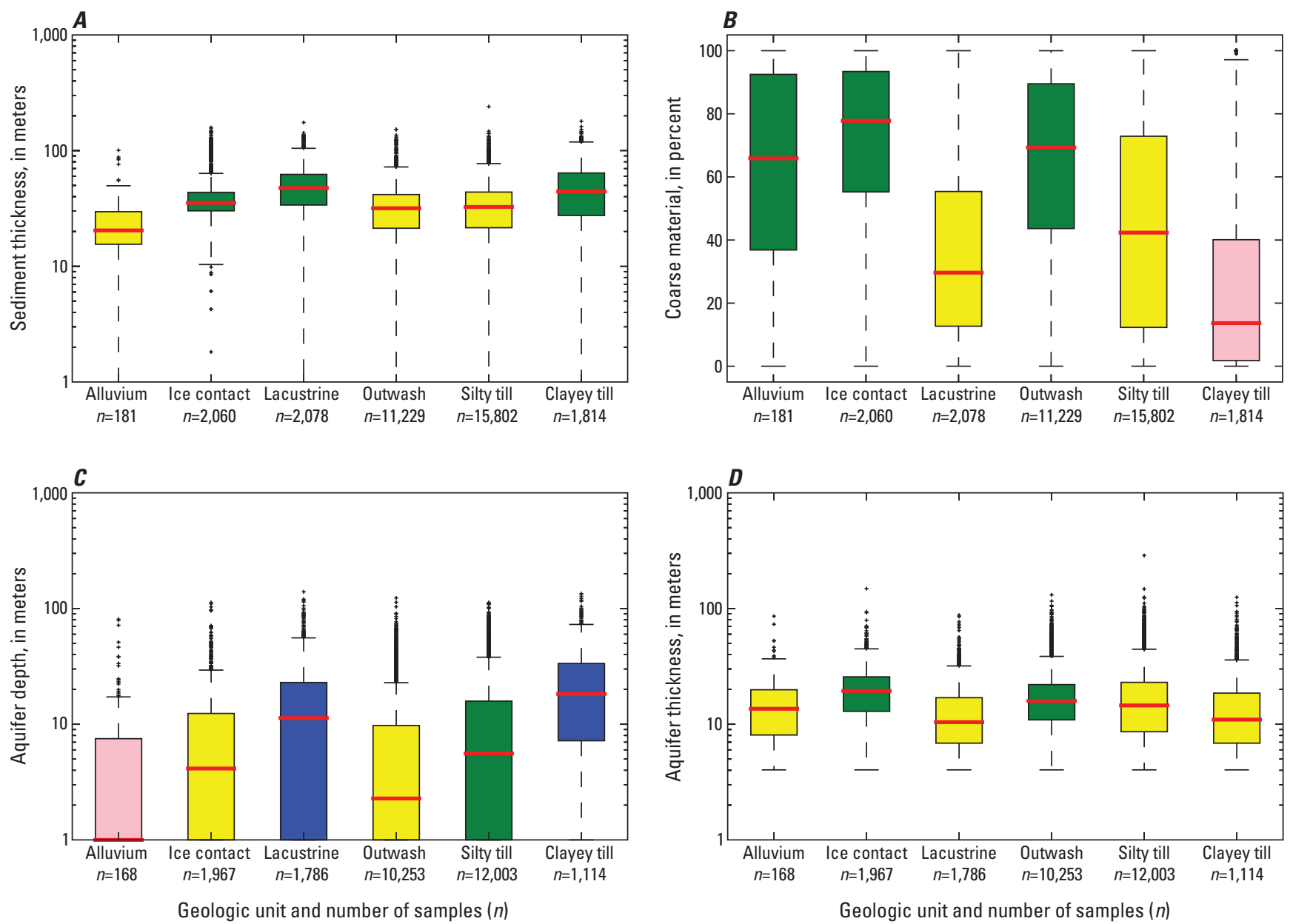

\section{EXPLANATION}
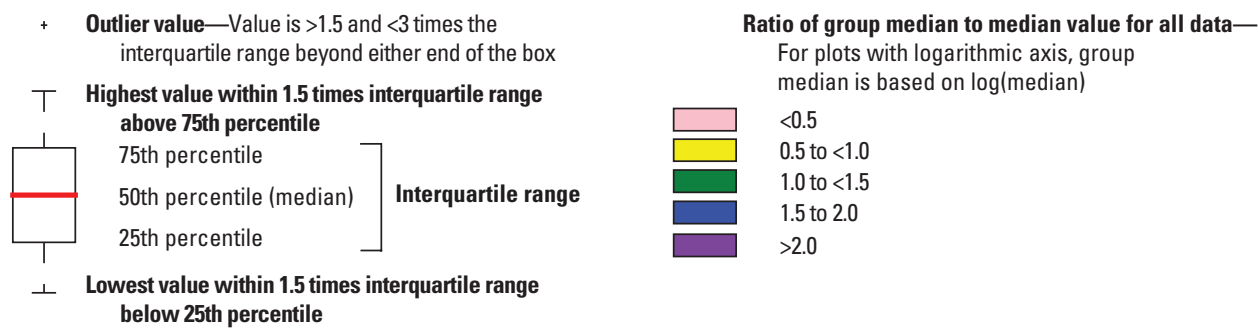

Figure 39. $A$, Quaternary thickness, $B$, percent of coarse material, $C$, depth, and $D$, thickness of aquifer-material intervals; and frequency distribution of percentages of material beneath $E$, coarse-textured and $F$, fine-textured map units grouped by map unit in terrane 2B in the glaciated conterminous United States. 

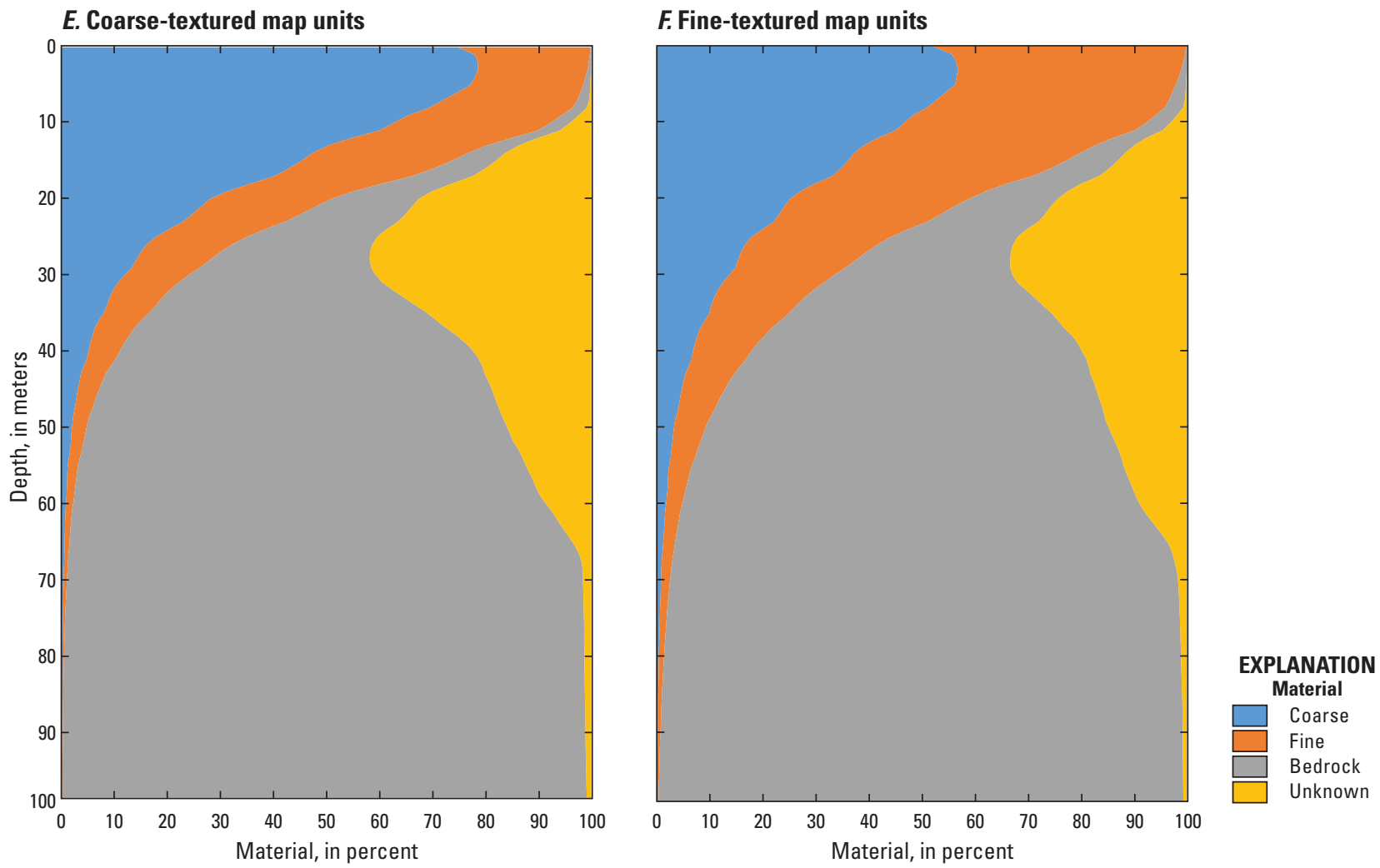

Figure 39. $A$, Quaternary thickness, $B$, percent of coarse material, $C$, depth, and $D$, thickness of aquifer-material intervals; and frequency distribution of percentages of material beneath $E$, coarse-textured and $F$, fine-textured map units grouped by map unit in terrane 2B in the glaciated conterminous United States.-Continued

\section{Terrane 2C-Late Wisconsinan Sediment in the Des Moines Lobe}

Hydrogeologic terrane $2 \mathrm{C}$ consists of a continuous cover of Quaternary sediment that overlies sedimentary bedrock in Iowa and southern Minnesota (figs. $2 C$ and 7). Silty till predominates on the uplands and covers 80 percent of the terrane (fig. 25), whereas coarse-grained, stratified sediment is confined generally to stream valleys (fig. 5). Quaternary sediment at land surface is of Late Wisconsinan age deposited by ice of the Des Moines lobe that advanced to the east of the Prairie Coteau; at depth, older sediments are preserved. The southern and eastern limit of this terrane is defined as the farthest extent of Late Wisconsinan glaciation. Other terrane boundaries are relatively arbitrary.

The density of lithologic logs is moderate (fig. 8). Median thickness of Quaternary sediment in lithologic logs ranges from 20 to $60 \mathrm{~m}$, and is thickest beneath areas where lacustrine sediments or silty till are at land surface (fig. 40A). The median percentage of coarse material in sediment is less than 20 percent and is highest beneath coarse-grained, stratified materials (alluvium, lacustrine sediments, and outwash; fig. 40B). The frequency distribution of material with depth indicates that, beneath coarse-textured map units, about
80 percent of coarse materials are within $38 \mathrm{~m}$ of land surface (fig. $40 E$ ). About 40 percent of the lithologic logs penetrated an aquifer-material interval (fig. 28A), and multiple intervals were penetrated in about 10 percent of the logs. Median depths to aquifer-material intervals penetrated in logs are 8 to $30 \mathrm{~m}$ (fig. 40C), and are deepest beneath lacustrine sediments and silty till. Median thickness of aquifer-material intervals ranged from 8 to $10 \mathrm{~m}$ (fig. $40 \mathrm{D}$ ). About 50 percent of water wells are completed in Quaternary sediment (fig. 28B), and nearly all are confined (fig. 28C). The probability of penetrating an aquifer-material interval is relatively high in the northern part of the terrane (fig. 14B), and intervals are likely confined (fig. 20B).

\section{Terrane 2D—Older Sediment in lowa and Kansas}

Hydrogeologic terrane 2D consists of older (mostly preIllinoian) sediment that overlies sedimentary bedrock south of the Late Wisconsinan ice margin in Kansas, Missouri, Iowa, and southeastern Minnesota (figs. $2 \mathrm{C}$ and 7). Silty to clayey till predominates on the uplands and covers nearly 80 percent of the terrane (fig. 25), becoming mostly silty to the east (figs. 5 and 6). Loess blankets the uplands to a notable degree, exceeding $6 \mathrm{~m}$ in thickness in the western part of the terrane 

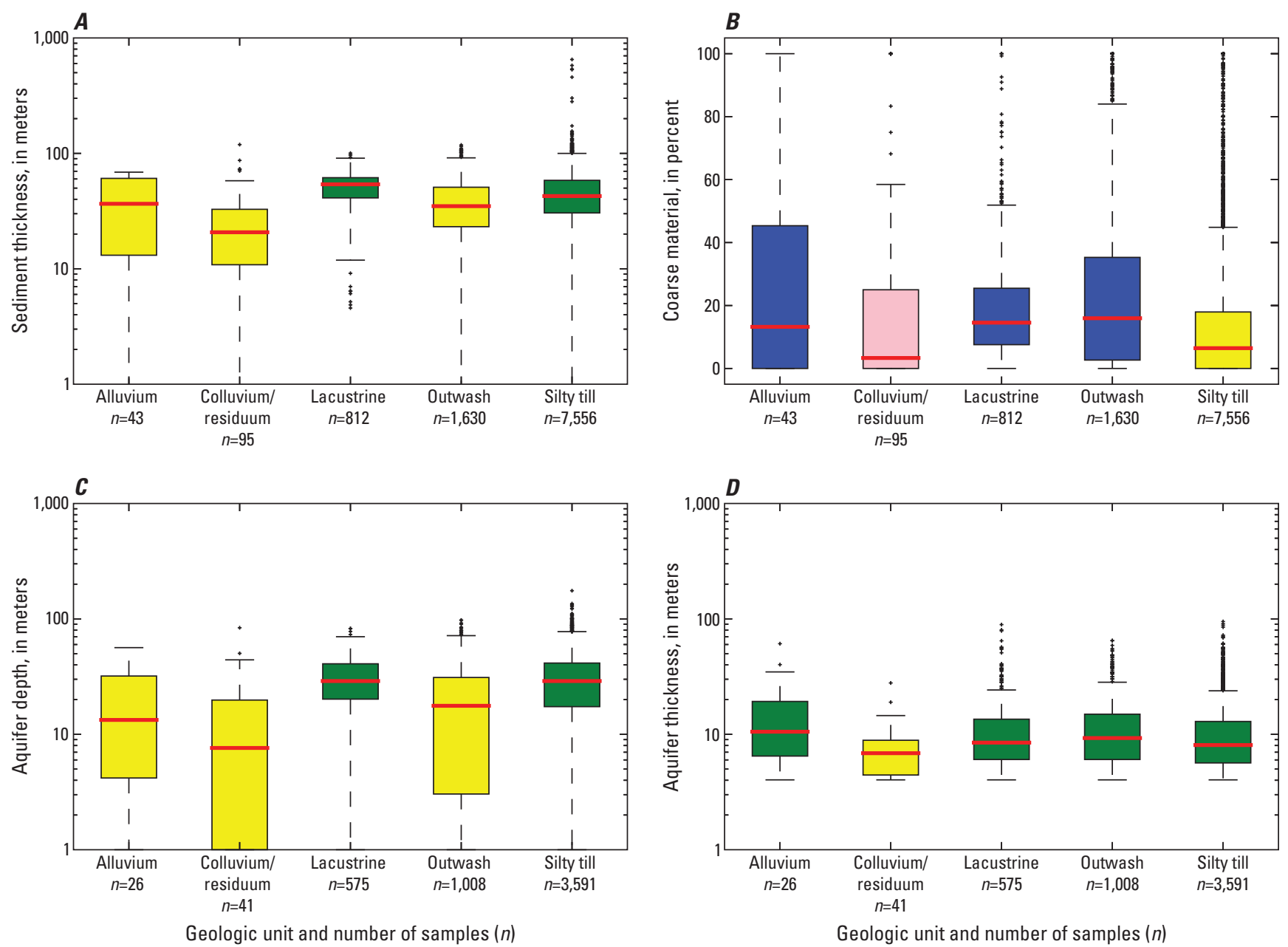

Geologic unit and number of samples $(n)$

EXPLANATION

$+\quad$ Outlier value - Value is $>1.5$ and $<3$ times the interquartile range beyond either end of the box

$\top$ Highest value within 1.5 times interquartile range

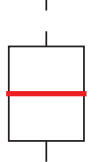
above 75 th percentile

75th percentile

50th percentile (median)

25th percentile

$\perp \quad$ Lowest value within 1.5 times interquartile range below 25 th percentile
Ratio of group median to median value for all dataFor plots with logarithmic axis, group median is based on log(median)

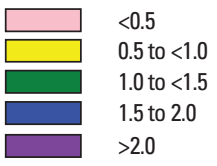

Figure 40. A, Quaternary thickness, $B$, percent of coarse material, $C$, depth, and $D$, thickness of aquifer-material intervals; and frequency distribution of percentages of material beneath $E$, coarse-textured and $F$, fine-textured map units grouped by map unit in terrane $2 \mathrm{C}$ in the glaciated conterminous United States. 


\section{E. Coarse-textured map units}

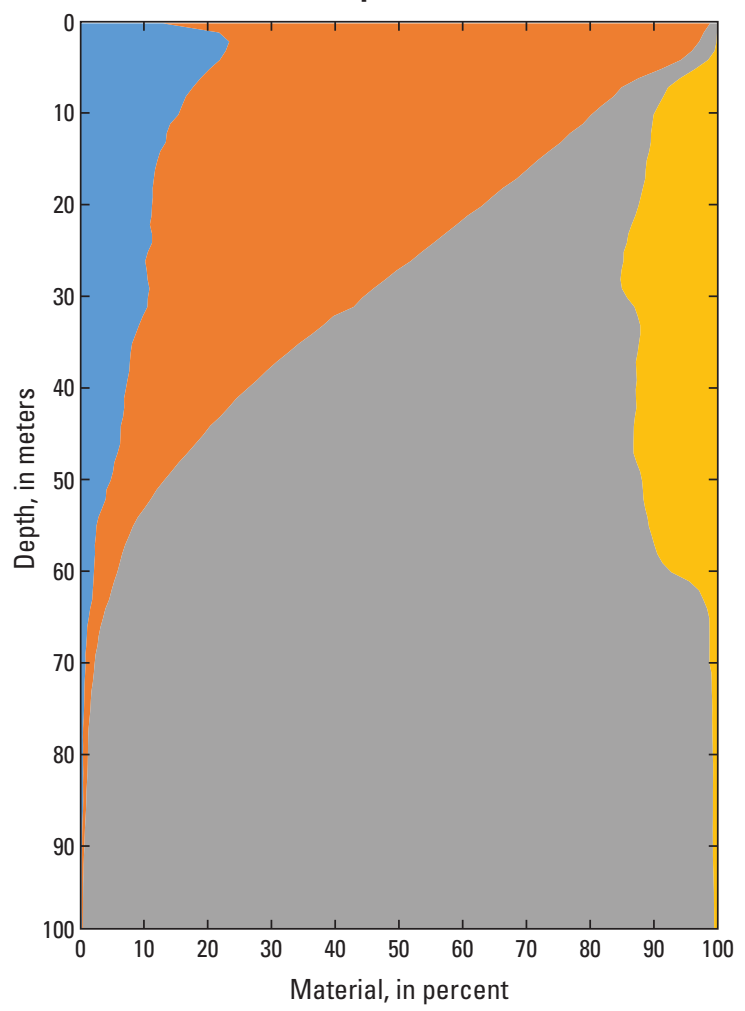

\section{F Fine-textured map units}

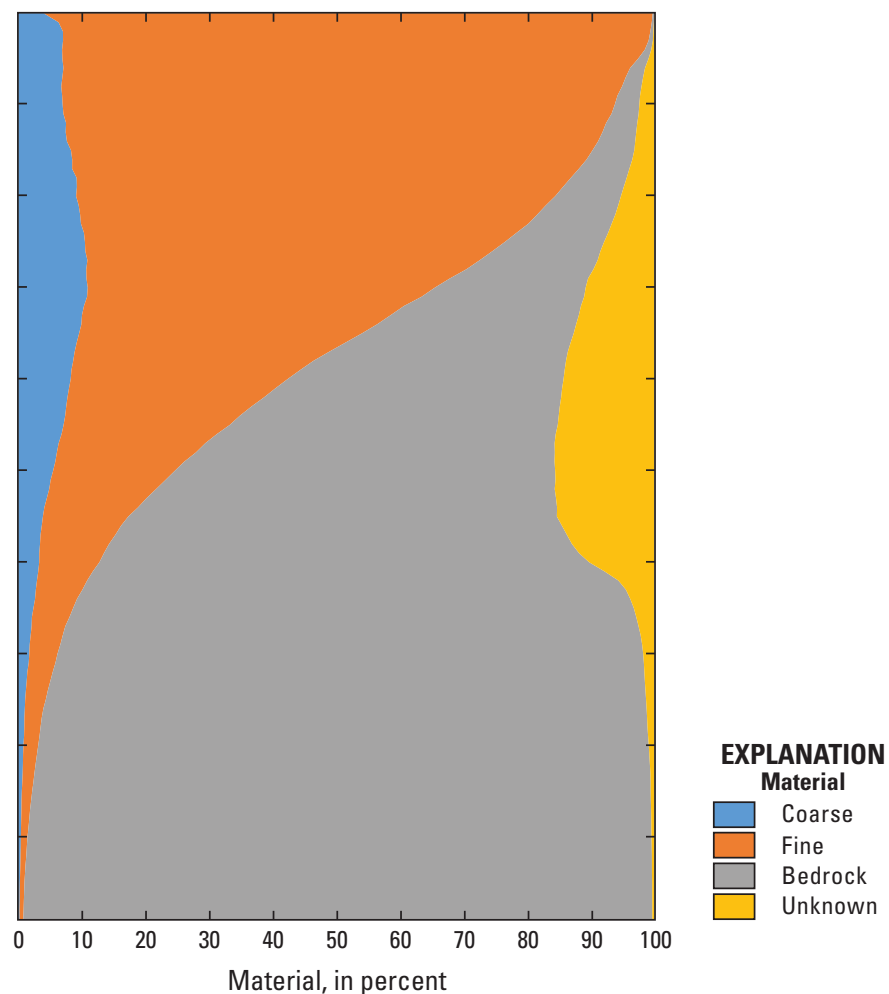

Figure 40. A, Quaternary thickness, $B$, percent of coarse material, $C$, depth, and $D$, thickness of aquifer-material intervals; and frequency distribution of percentages of material beneath $E$, coarse-textured and $F$, fine-textured map units grouped by map unit in terrane $2 \mathrm{C}$ in the glaciated conterminous United States. - Continued

(Roberts and others, 2007). Coarse-grained, stratified sediment (mostly alluvium) is generally confined to stream valleys. Example well logs in Soller (1997), give some indication of this variability at depth. The boundaries of the terrane are relatively arbitrary, except where it abuts terrane $2 \mathrm{C}$; there it is defined as the maximum extent of Late Wisconsinan glaciation.

The density of lithologic logs in this terrane is variable (fig. 8), high in the eastern and western parts of the terrane, and very low in south central Iowa. Median thickness of Quaternary sediment in lithologic logs ranges from 12 to $40 \mathrm{~m}$, is thickest in areas of silty till, and is thinnest beneath areas of outwash (fig. 41A). The median percentage of coarse material in sediment is quite variable and ranges from almost 60 percent beneath areas of alluvium to less than 5 percent beneath silty till and outwash (fig. 41B). The low percentage of coarse material beneath outwash probably reflects the presence of underlying fine-grained sediment from previous glaciations. The frequency distribution of material with depth indicates that, beneath coarse-textured map units, about 80 percent of coarse materials are within $25 \mathrm{~m}$ of land surface (fig. $41 E$ ). About 50 percent of the lithologic logs penetrated an aquifer-material interval (fig. 28A), and multiple intervals were penetrated in about 10 percent of the logs. Median depths of aquifer-material intervals penetrated in logs are 2 to $6 \mathrm{~m}$ beneath areas of stratified sediment, and $30 \mathrm{~m}$ beneath silty till (fig. $41 C$ ). Median thickness of aquifer-material intervals ranged from 10 to $20 \mathrm{~m}$ (fig. $41 \mathrm{D}$ ) and are thickest under areas of alluvium. About 30 percent of water wells are completed in Quaternary sediment (fig. 28B) and are twice as likely to be confined as unconfined (fig. 28C). Thick deposits of unconfined, aquifer-material intervals underlie the valleys of the Missouri River and tributaries (fig. 20A). The probability of penetrating an aquifer-material interval is relatively high in the western part of the terrane (fig. 14B), and intervals are likely to be confined (fig. 20B). Most of the wells in the northeastern part of the terrane are completed in carbonate bedrock (fig. 7).

\section{Terrane 2E-Late Wisconsinan Sediment in the Dakotas}

Hydrogeologic terrane 2E consists of a nearly continuous cover of Quaternary sediment that overlies sedimentary rocks in eastern North and South Dakota (figs. $2 E$ and 7). Silty till predominates on the uplands and covers 70 percent of the terrane (figs. 5 and 25). Broad areas of coarse- and fine-grained stratified sediment also are present on some 

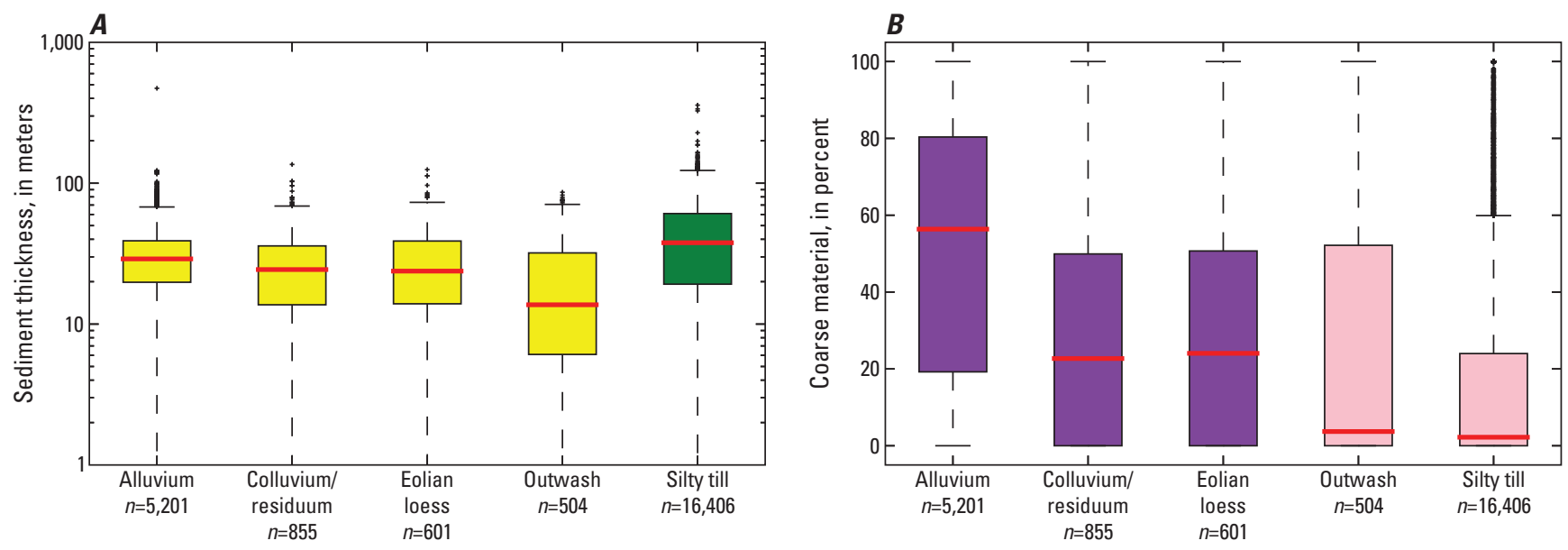

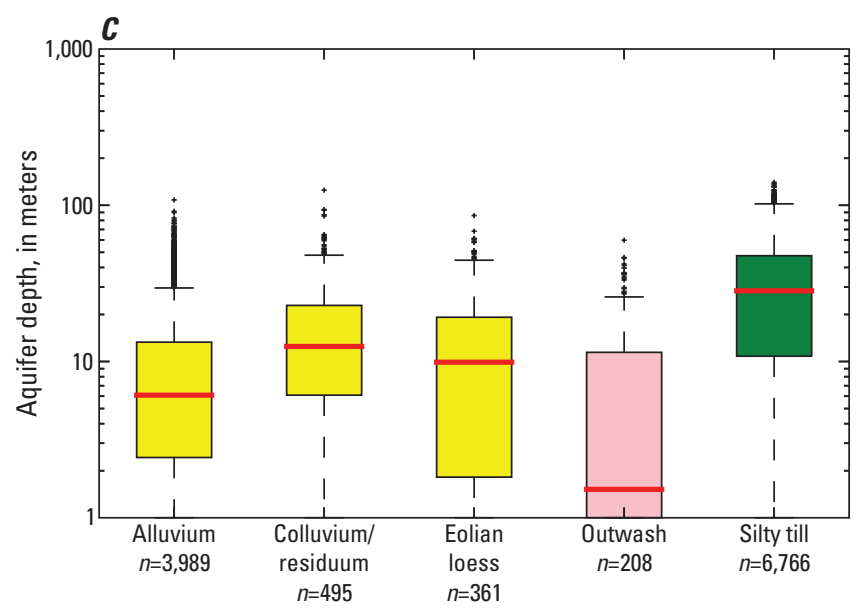

Geologic unit and number of samples $(n)$

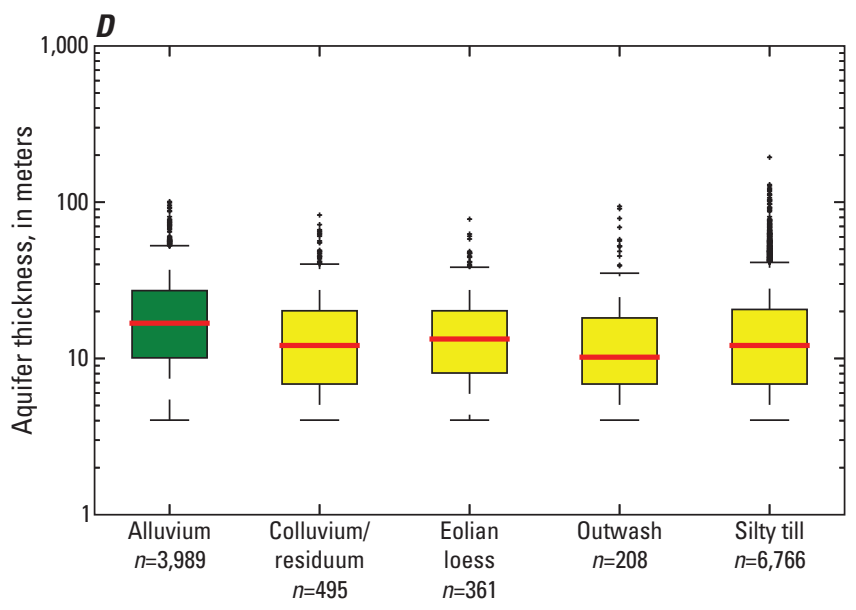

Geologic unit and number of samples $(n)$

\section{EXPLANATION}

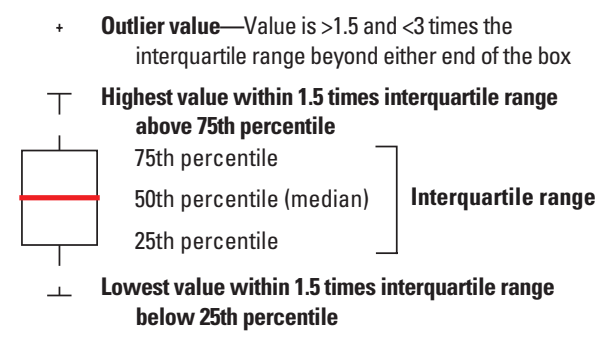

Figure 41. $A$, Quaternary thickness, $B$, percent of coarse material, $C$, depth, and $D$, thickness of aquifer-material intervals; and frequency distribution of percentages of material beneath $E$, coarse-textured and $F$, fine-textured map units grouped by map unit in terrane $2 \mathrm{D}$ in the glaciated conterminous United States. 

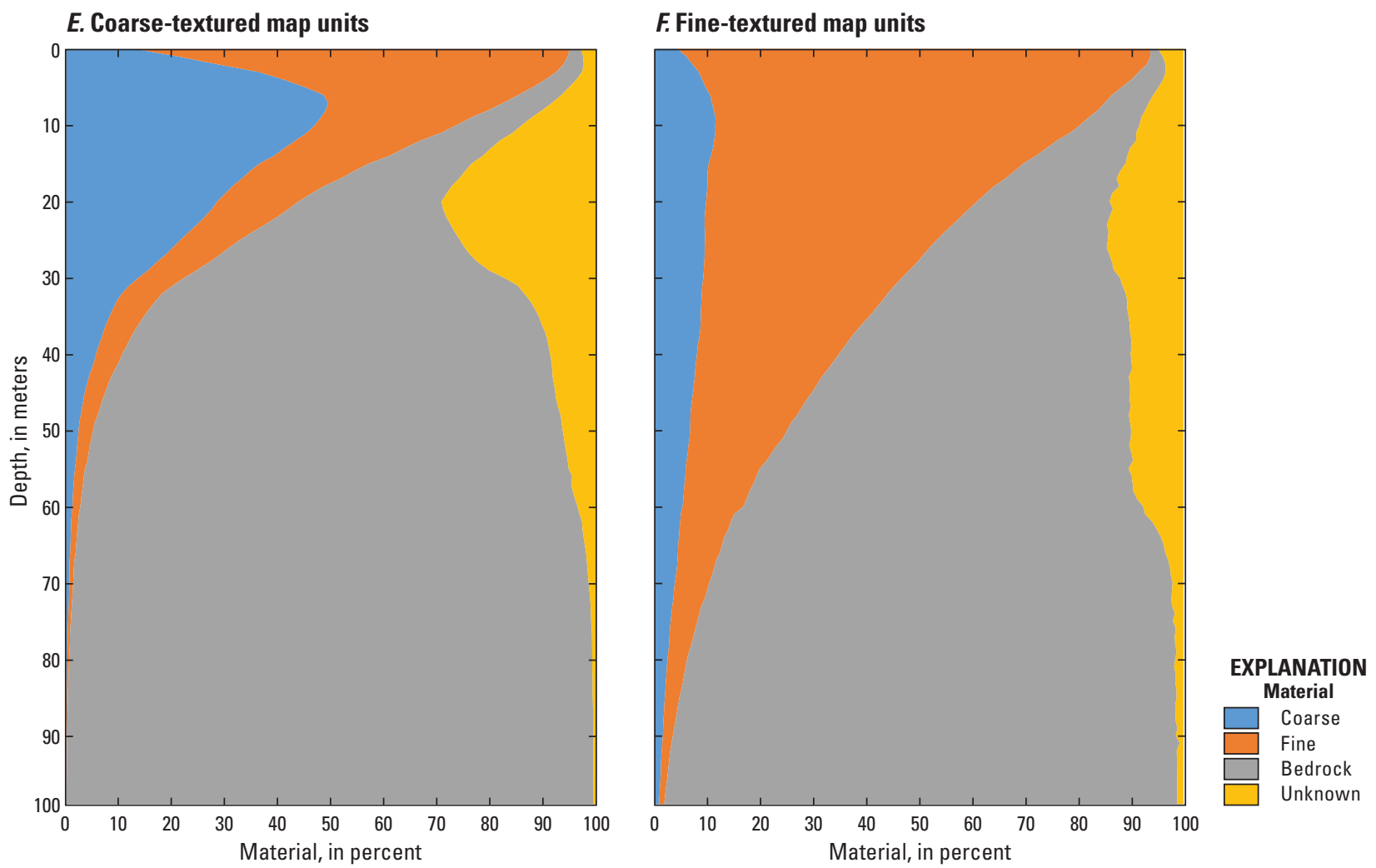

Figure 41. $A$, Quaternary thickness, $B$, percent of coarse material, $C$, depth, and $D$, thickness of aquifer-material intervals; and frequency distribution of percentages of material beneath $E$, coarse-textured and $F$, fine-textured map units grouped by map unit in terrane $2 \mathrm{D}$ in the glaciated conterminous United States.-Continued

uplands, which are dotted with prairie potholes, or kettle lakes. Fine-grained lacustrine sediments from pro-glacial lakes occupy lowlands along the Souris and James Rivers (fig. 5). Quaternary sediment at land surface is mostly of Late Wisconsinan age, whereas older sediment is preserved beyond the Late Wisconsinan ice margin and at depth. Example well logs in Soller (1997) give some indication of variability in areas of thicker sediment. The boundaries for this terrane are relatively arbitrary.

The density of lithologic logs is sparse (fig. 8), with a high density of logs in South Dakota. Median thickness of Quaternary sediment in lithologic logs ranges from 20 to $50 \mathrm{~m}$ (fig. $42 \mathrm{~A}$ ). The median percentage of coarse material in sediment ranges from 10 to 35 percent and is highest under eolian loess, ice-contact sediments, and outwash (fig. 42B). The frequency distribution of material with depth indicates that, beneath coarse-textured map units, about 80 percent of coarse materials are within $32 \mathrm{~m}$ of land surface (fig. 42E). About 50 percent of the lithologic logs penetrated an aquifer-material interval (fig. 28A), and multiple intervals were penetrated in about 10 percent of the logs. Median depths to aquifermaterial intervals penetrated in logs are 4 to $7 \mathrm{~m}$ beneath areas of stratified sediment and $20 \mathrm{~m}$ beneath areas of silty till (fig. 42C). Median thickness of aquifer-material intervals ranged from 8 to $13 \mathrm{~m}$ (fig. $42 \mathrm{D}$ ). About 75 percent of water wells are completed in Quaternary sediment (fig. 28B) and are equally likely to be unconfined or confined (fig. 28C). Extensive confined intervals of aquifer material are in buried, preglacial valleys that are filled with Quaternary sediment. The Spiritwood aquifer system in North Dakota is a primary example (Kehew and Boettger, 1986).

\section{Hydrogeologic Terranes of Higher Complexity}

\section{Terrane 3A-Interlobate Area in Southern Michigan Between Lake Michigan, Saginaw, and Lake Huron-Erie Lobes}

Hydrogeologic terrane 3A consists of thick sequences of Quaternary sediment composed of multiple till sheets and intercalated stratified sediment (mostly sands and gravels) that overlies sedimentary bedrock in Michigan's Southern Peninsula (figs. $2 B$ and 7). This terrane is roughly delineated by the interlobate region between the ice sheets of the Michigan and Huron-Erie lobes. Sediment thickness commonly exceeds $100 \mathrm{~m}$ in the northern part of the terrane (fig. 12A). Till is mostly sandy to silty in texture and covers 45 percent of 

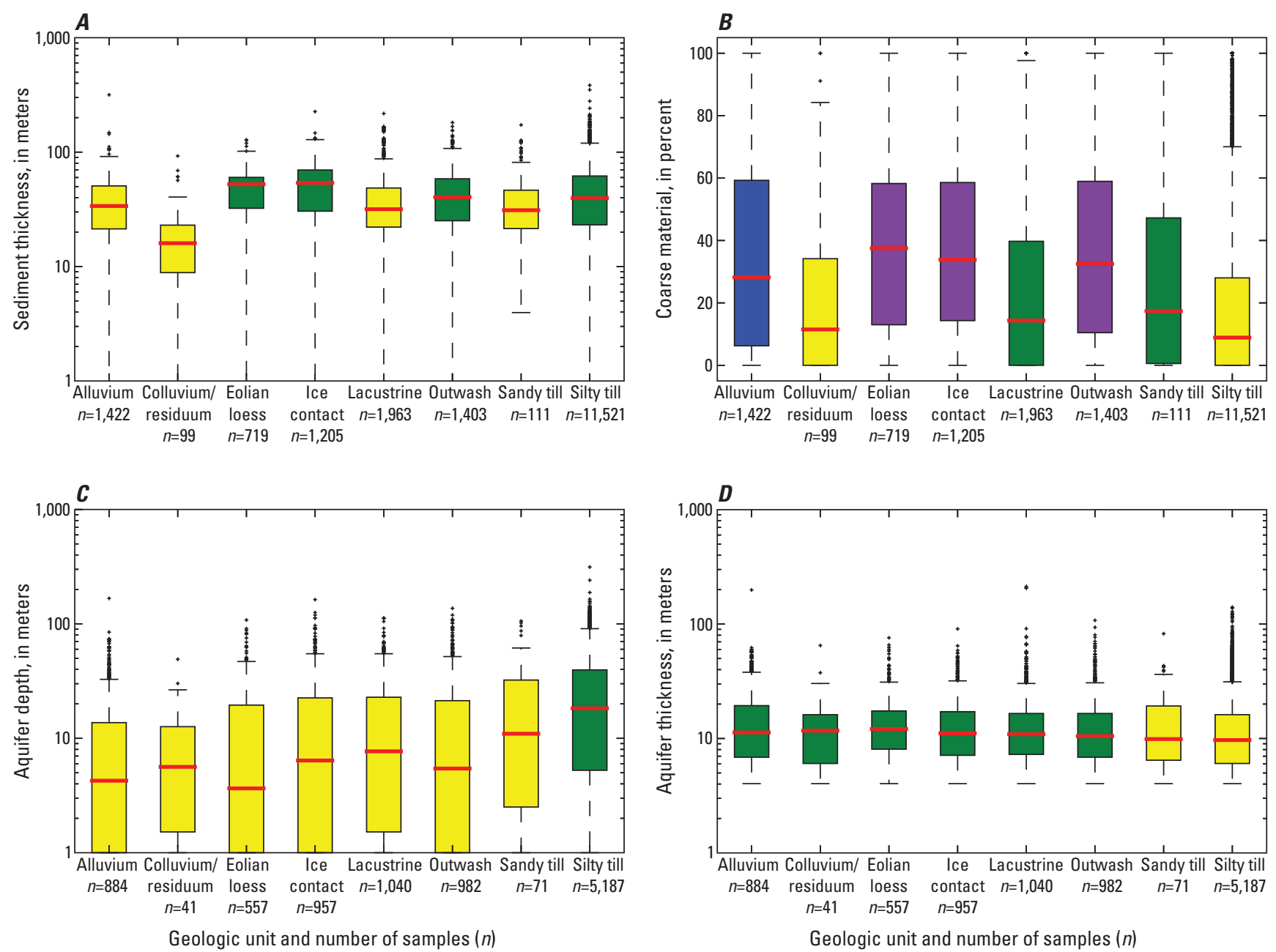

\section{EXPLANATION}
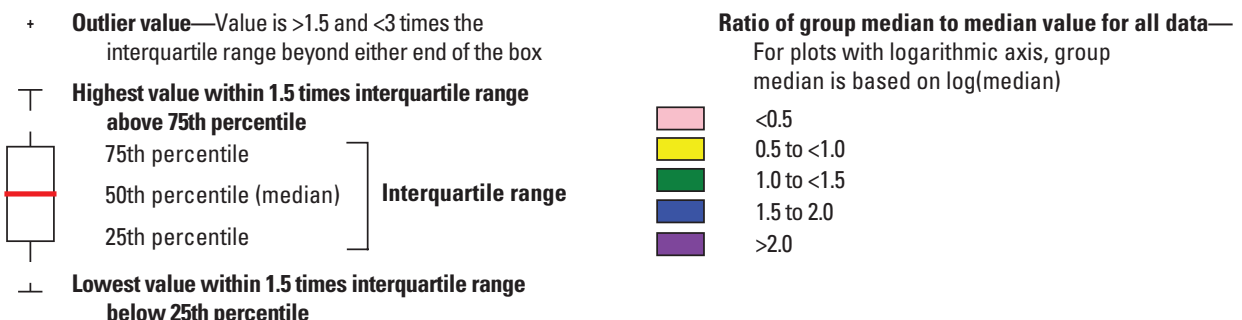
below 25th percentile

Figure 42. $A$, Quaternary thickness, $B$, percent of coarse material, $C$, depth, and $D$, thickness of aquifer-material intervals; and frequency distribution of percentages of material beneath $E$, coarse-textured and $F$, fine-textured map units grouped by map unit in terrane $2 \mathrm{E}$ in the glaciated conterminous United States. 

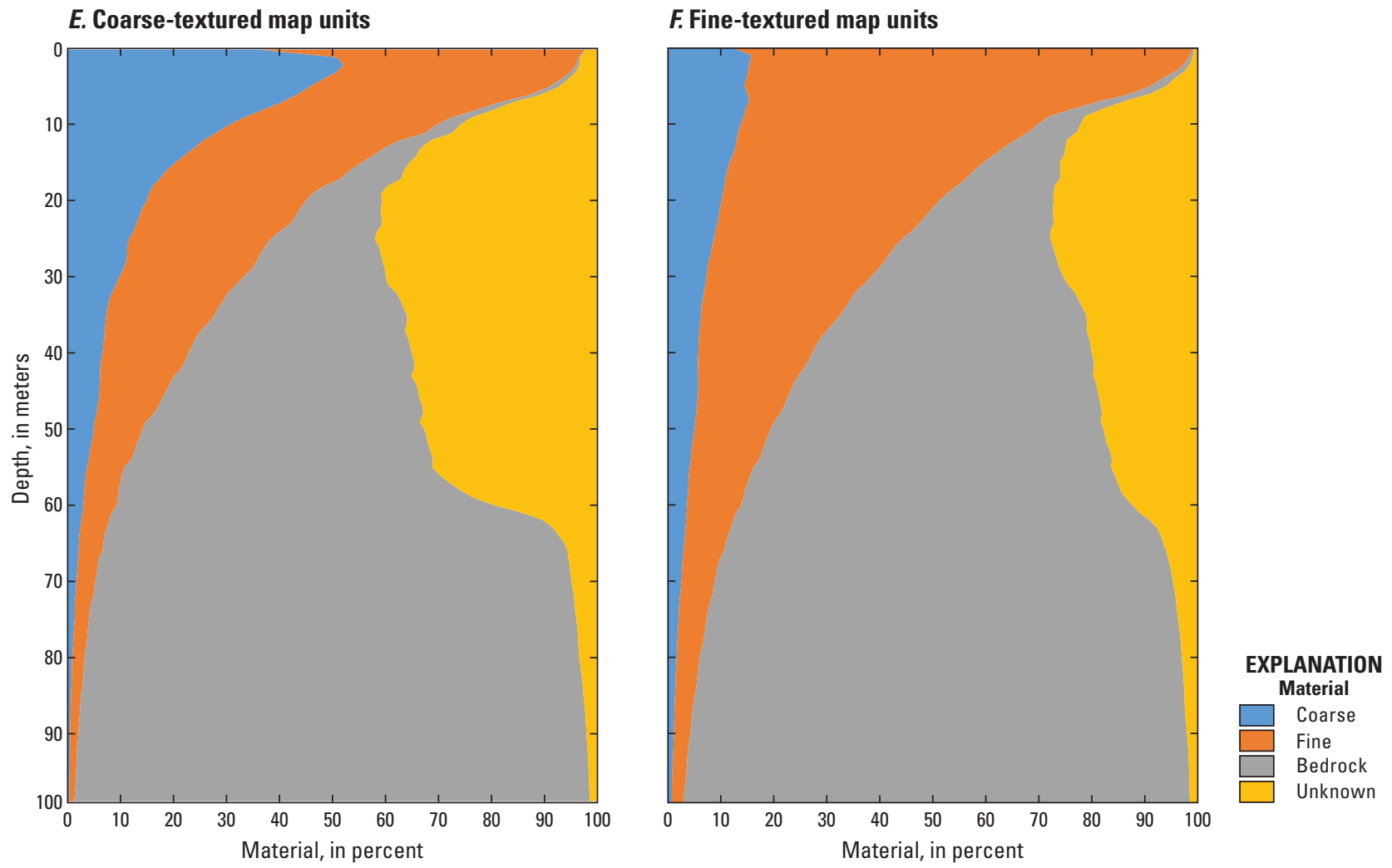

Figure 42. A, Quaternary thickness, $B$, percent of coarse material, $C$, depth, and $D$, thickness of aquifer-material intervals; and frequency distribution of percentages of material beneath $E$, coarse-textured and $F$, fine-textured map units grouped by map unit in terrane $2 \mathrm{E}$ in the glaciated conterminous United States. - Continued

the terrane (fig. 25). Stratified sediment is widespread at land surface and is mostly coarse-grained, except for fine-grained, lacustrine sediment in the lowlands southwest of Saginaw Bay (fig. 12B). The example well logs in Soller (1998) for Michigan convey the level of complexity of sediments in this terrane. The boundaries of this terrane mainly are based on sediment thickness.

The density of lithologic logs is relatively high (fig. 8), but the usage of wells associated with the logs is not recorded in Michigan; therefore, plots pertaining to water wells only incorporate data from Indiana. Median thickness of Quaternary sediment in lithologic logs ranges from 70 to $110 \mathrm{~m}$ (fig. $43 \mathrm{~A}$ ). The median percentage of coarse material in stratified sediment is about 60 percent (fig. $43 B$ ), except for lacustrine sediment ( 30 percent). The median percentage of coarse material in till ranges from 20 to 35 percent. The frequency distribution of material with depth indicates that, beneath coarse-textured map units, about 80 percent of coarse materials are within $19 \mathrm{~m}$ of land surface (fig. $43 E$ ). About 80 percent of the lithologic logs penetrated an aquifer-material interval (fig. 28A), and multiple intervals were penetrated in about 15 percent of the logs. Median depths of aquifermaterial intervals penetrated in logs are $8 \mathrm{~m}$ or less (fig. $43 \mathrm{C}$ ), except beneath areas of clayey till $(12 \mathrm{~m})$. Median thickness of aquifer-material intervals ranged from 10 to $20 \mathrm{~m}$ (fig. 43D).
Almost all water wells in this terrane in Indiana are completed in Quaternary sediment (fig. 28B) and are more likely to be confined than unconfined (fig. 28C). Extensive, thick deposits of unconfined aquifer material are throughout the terrane (fig. 20A), but aquifer-material intervals are likely to be confined in the southern part of the terrane in Indiana (fig. 20B). A numerical representation of Quaternary sediment in a groundwater flow model of unconsolidated and bedrock aquifers in the Lake Michigan Basin treated the entire sediment thickness in this terrane as a single aquifer system without extensive confining units (Feinstein and others, 2010).

\section{Terrane 3B-Interlobate Area in Minnesota Between Labrador and Keewatin Laurentide Centers}

Hydrogeologic terrane 3B consists of thick sequences of Quaternary sediment composed of multiple till sheets and intercalated stratified sediment (mostly sands and gravels) over sedimentary, igneous (plutonic and volcanic), and metamorphic rock in Minnesota and the eastern Dakotas (figs. $2 D$ and 7). Quaternary sediment was deposited by ice from the western (Keewatin) and eastern (Labrador) centers of ice accumulation in the Laurentide ice sheet. Ice flowed south from 

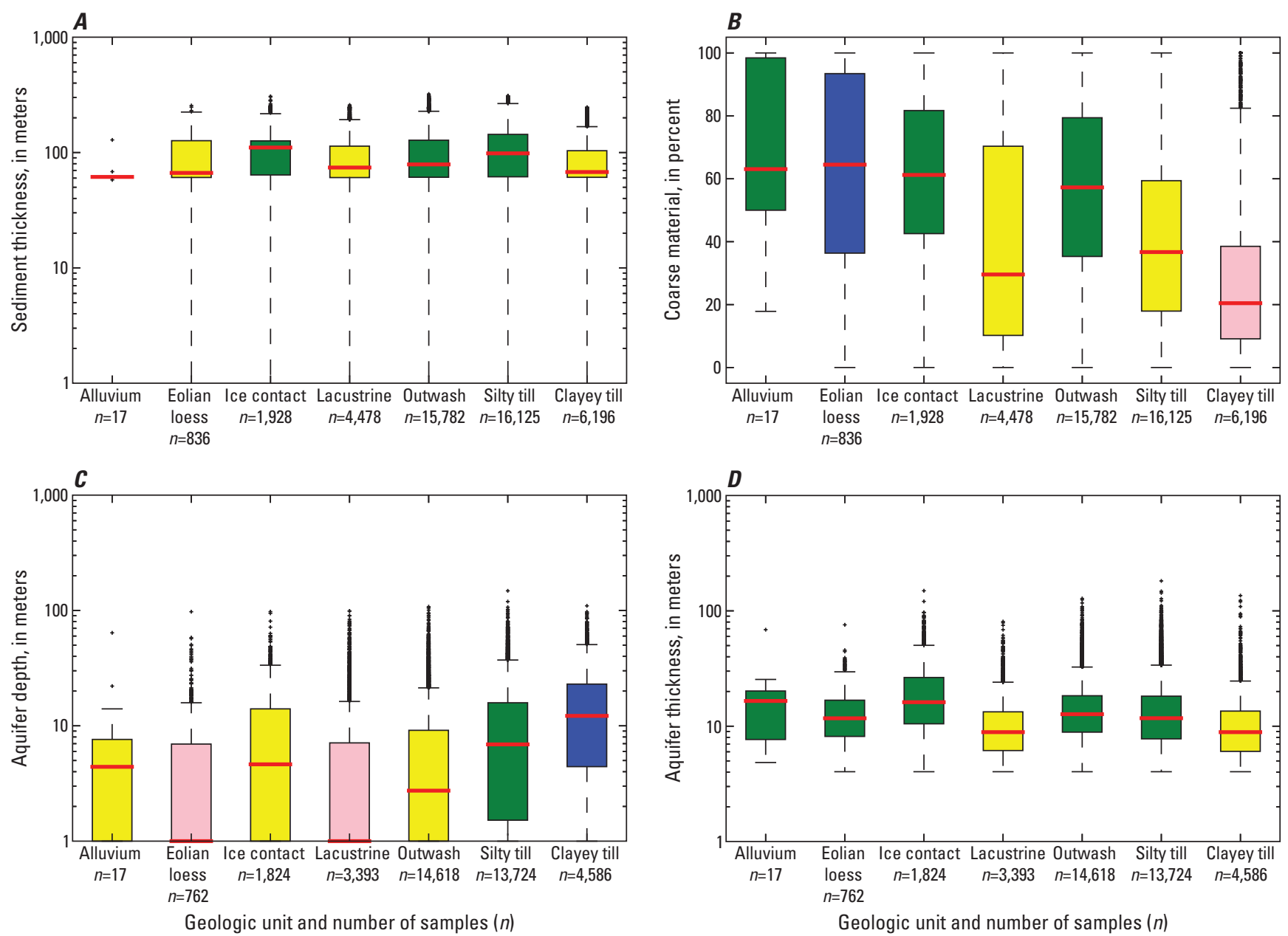

EXPLANATION
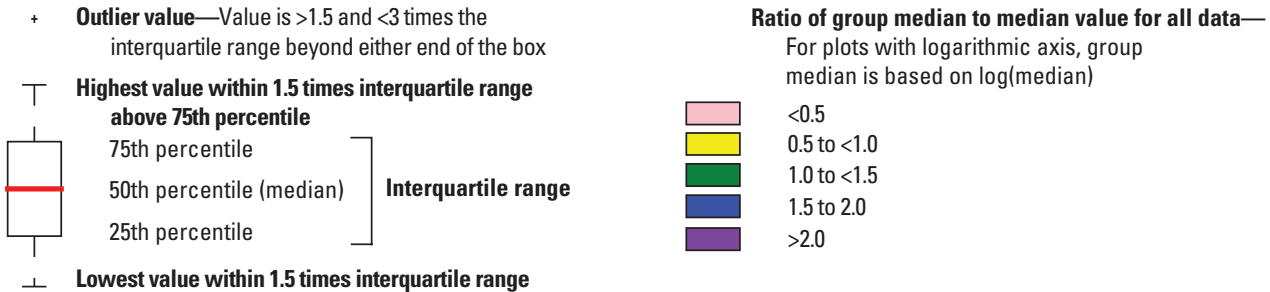
below 25th percentile

Figure 43. $A$, Quaternary thickness, $B$, percent of coarse material, $C$, depth, and $D$, thickness of aquifer-material intervals; and frequency distribution of percentages of material beneath $E$, coarse-textured and $F$, fine-textured map units grouped by map unit in terrane $3 \mathrm{~A}$ in the glaciated conterminous United States. 

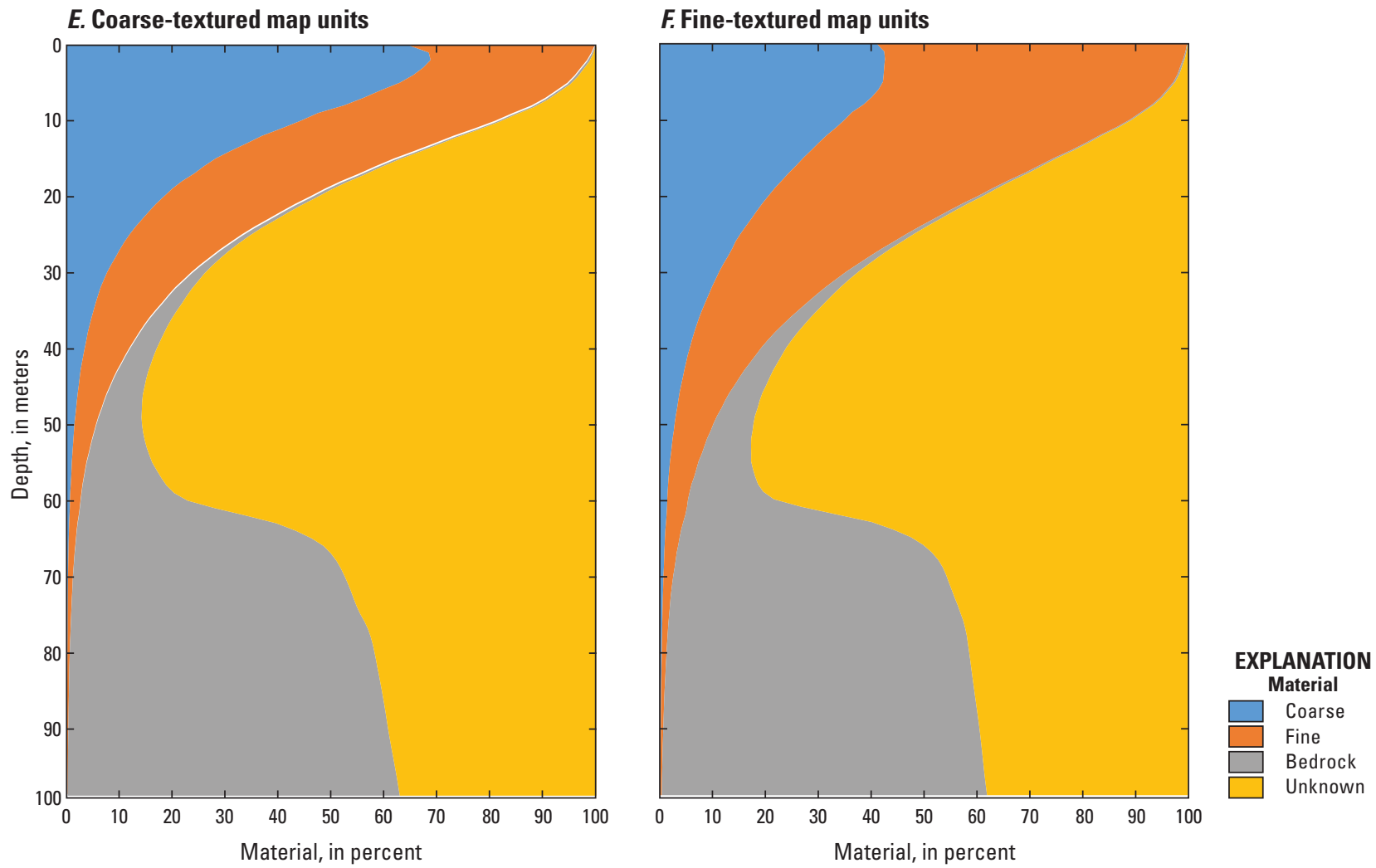

Figure 43. $A$, Quaternary thickness, $B$, percent of coarse material, $C$, depth, and $D$, thickness of aquifer-material intervals; and frequency distribution of percentages of material beneath $E$, coarse-textured and $F$, fine-textured map units grouped by map unit in terrane $3 \mathrm{~A}$ in the glaciated conterminous United States.-Continued

the Keewatin center in the Red River lobe, whereas ice flowed southwest from the Labrador center in the Lake Superior lobe (lobes were centered in western Canada north of the Red River and north of Lake Superior, respectively). The interaction between these ice lobes formed a thick, highly complex stack of sediment that is poorly delineated in the subsurface. Sediment commonly exceeds $100 \mathrm{~m}$ throughout the terrane (fig. 12A). Till is silty sandy to clayey in texture and covers 45 percent of the terrane (fig. 25). Stratified sediment is mostly outwash with some lacustrine sediment in the Red River valley, the former location of glacial Lake Agassiz. Extensive deposits of organic sediment (peat) in northern Minnesota cover 7 percent of the terrane (figs. 5 and 25).

The density of lithologic logs in this terrane is relatively high (fig. 8). Median thickness of Quaternary sediment in lithologic logs generally ranges from 60 to $90 \mathrm{~m}$ with little variability, but is slightly less $(50 \mathrm{~m})$ beneath areas where alluvium is at land surface (fig. 44A). The median percentage of coarse material (fig. $44 B$ ) is highest beneath outwash and ice-contact sediments ( 45 to 50 percent) and is about 20 to 30 percent for other map units in the terrane. The frequency distribution of material with depth indicates that, beneath coarse-textured map units, about 80 percent of coarse materials are within $25 \mathrm{~m}$ of land surface (fig. $44 E$ ). About
80 percent of the lithologic logs penetrated an aquifer-material interval (fig. 28A), and multiple intervals were penetrated in about 30 percent of the logs. Median depths of aquifermaterial intervals penetrated in logs range from 10 to $30 \mathrm{~m}$ (fig. 44C), except beneath eolian loess (4 m). Median thickness ranged from 10 to $20 \mathrm{~m}$ (fig. $44 D$ ). About 75 percent of water wells are completed in Quaternary sediment (fig. 28B) and are nearly twice as likely to be confined as unconfined (fig. 28C). Most of the bedrock water wells are in the southeastern part of the terrane where it overlies the regional Cambrian-Ordovician aquifer (fig. $2 D$ ). Aquifer-material intervals are reliably penetrated throughout the terrane (fig. 14B), and thick deposits of unconfined aquifer material are present in the central part of the terrane (fig. 20A). Aquifer-material intervals in most of the terrane are likely to be confined, however (fig. 20B).

\section{Terrane 3C-Prairie Coteau}

Hydrogeologic terrane 3C (fig. 2C) consists of thick sequences of Quaternary sediment beneath the Prairie Coteau region (eastern South Dakota, southwestern Minnesota, and northwestern Iowa), composed of multiple till sheets and 

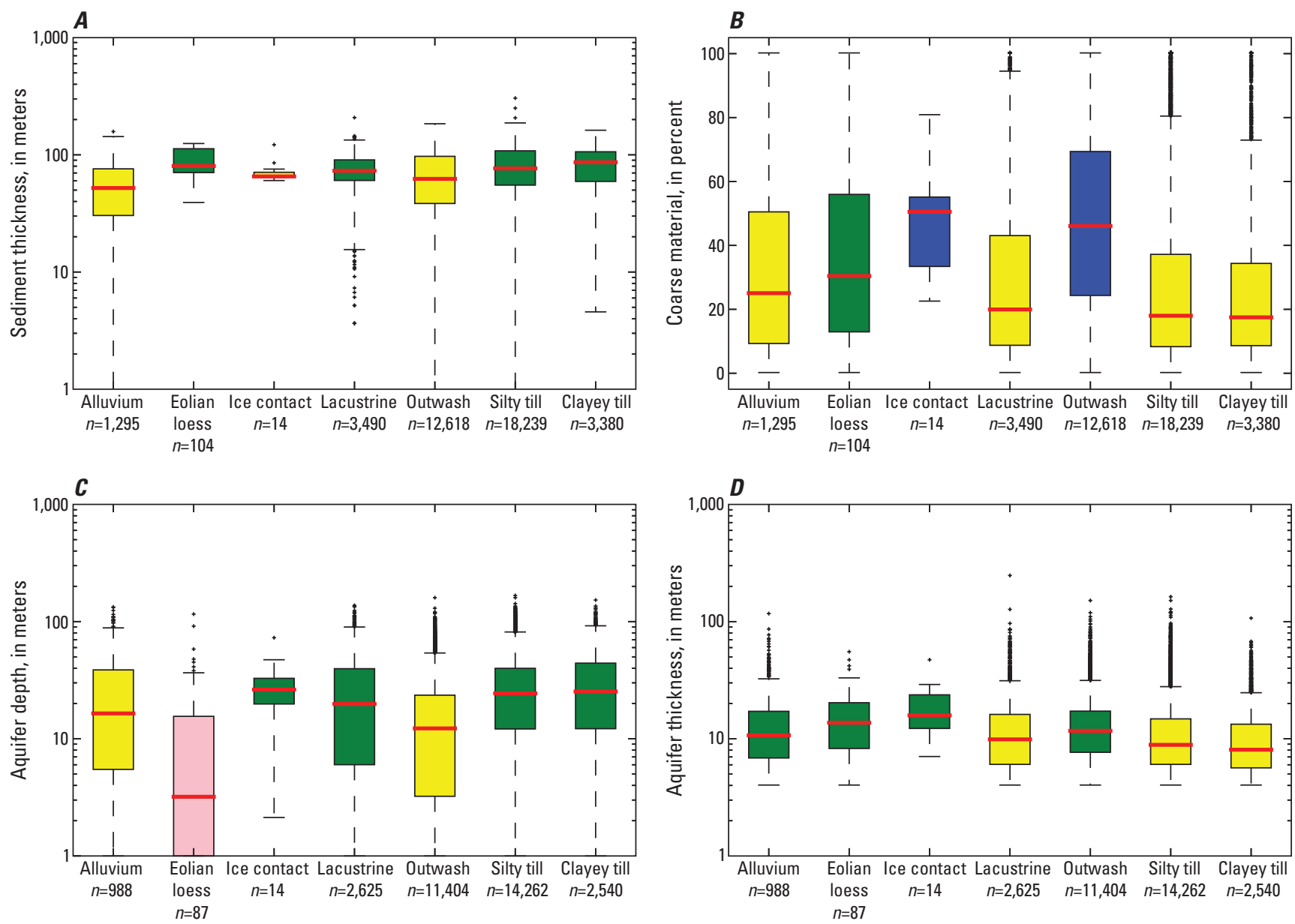

Geologic unit and number of samples $(n)$

Geologic unit and number of samples $(n)$

\section{EXPLANATION}

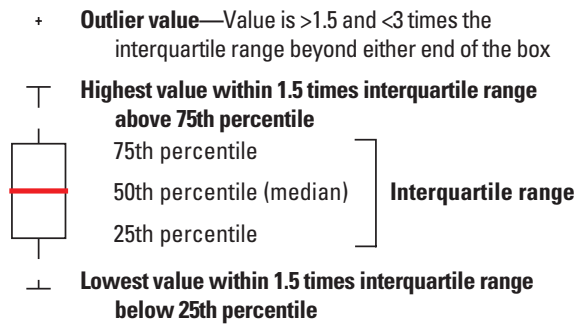
Ratio of group median to median value for all data- For plots with logarithmic axis, group median is based on log(median)




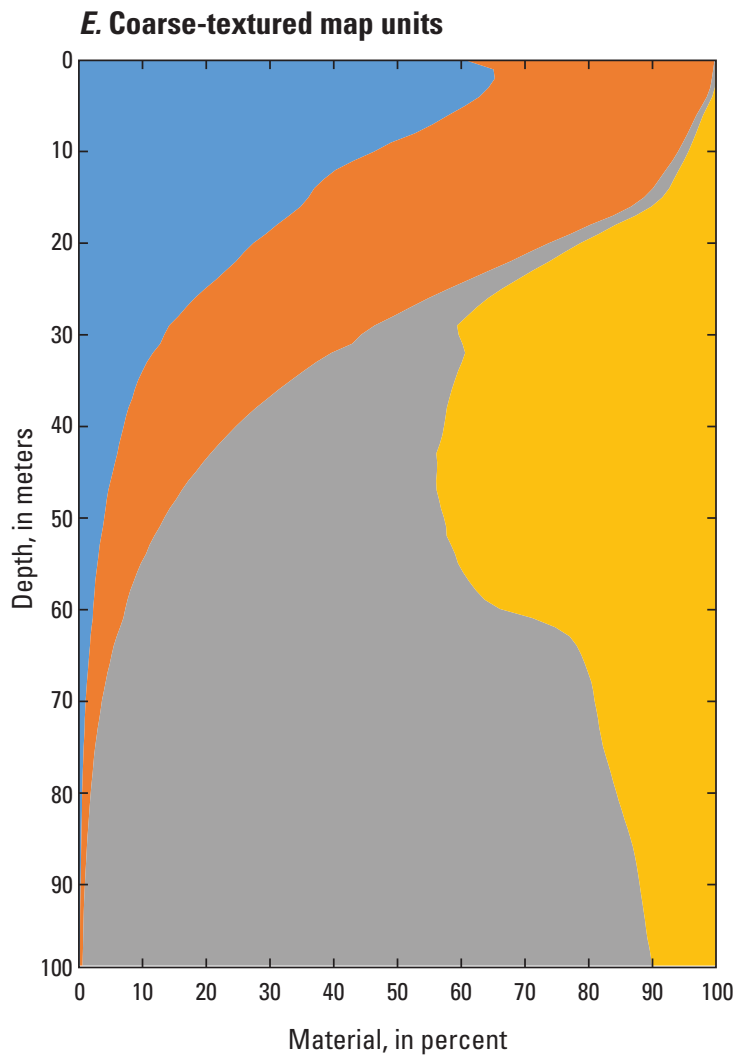

\section{F. Fine-textured map units}

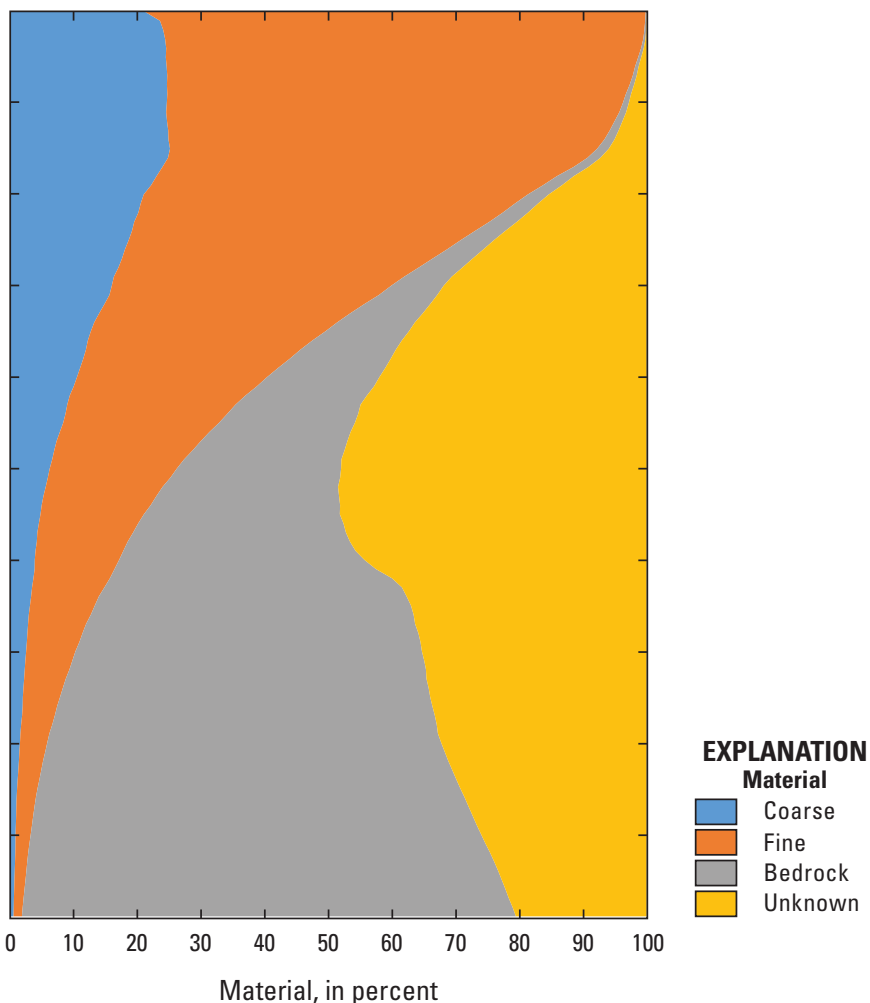

Figure 44. $A$, Quaternary thickness, $B$, percent of coarse material, $C$, depth, and $D$, thickness of aquifer-material intervals; and frequency distribution of percentages of material beneath $E$, coarse-textured and $F$, fine-textured map units grouped by map unit in terrane 3B in the glaciated conterminous United States.-Continued

intercalated stratified sediment (mostly sands and gravels) over sedimentary bedrock (fig. 7). Quaternary sediment beneath the Prairie Coteau was deposited from interaction of ice in the interlobate region between the James and Des Moines lobes. Sediment thickness commonly exceeds $100 \mathrm{~m}$ (fig. $12 \mathrm{~A}$ ), and silty till predominates at land surface and covers 80 percent of the terrane (figs. 5 and 25). Most of the coarse-grained sediment is outwash deposited in the valleys of the Big and Little Sioux Rivers, but extensive ice-contact sediments overlie uplands in the northern part of the terrane (fig. 5). The example well log in Soller (1997) for South Dakota conveys the level of complexity of sediments in this terrane. The boundaries of the terrane are based mostly on sediment thickness and topographic expression of the Prairie Coteau region.

The density of lithologic logs is moderate (fig. 8). Median thickness of Quaternary sediment in lithologic logs generally ranges from 70 to $140 \mathrm{~m}$ with little variability, but is slightly less $(50 \mathrm{~m})$ beneath alluvium (fig. $45 \mathrm{~A})$. The median percentage of coarse material ranges from 20 to 40 percent beneath alluvium, ice-contact sediments, and outwash (fig. 45B) and is 10 percent or less for other map units in terrane. The frequency distribution of material with depth indicates that, beneath coarse-textured map units, about 80 percent of coarse materials are within $19 \mathrm{~m}$ of land surface (fig. 45E). About 50 percent of the lithologic logs penetrated an aquifer-material interval (fig. 28A), and multiple intervals were penetrated in less than 10 percent of the logs. Median depths of aquifermaterial intervals penetrated in logs were less than $2 \mathrm{~m}$ beneath ice-contact sediments, and outwash (fig. 45C) and as much as $30 \mathrm{~m}$ beneath silty till. Median thickness of aquifermaterial intervals ranged from 8 to $13 \mathrm{~m}$ (fig. $45 \mathrm{D}$ ). About 75 percent of water wells are completed in Quaternary sediment (fig. 28B) and are mostly confined (fig. 28C). Aquifermaterial intervals that are penetrated within the terrane are most likely confined (fig. 20B), except in areas underlain by ice-contact or outwash sediments.

\section{Hydrogeologic Terranes with Thick Coarse- Grained, Stratified Quaternary Sediment}

\section{Terrane 4A—Long Island and Cape Cod}

Hydrogeologic terrane 4A includes glaciated areas on Cape Cod and Long Island (fig. 2A). Quaternary aquifers beneath Long Island and Cape Cod are bounded by saltwater. On Long Island, the glaciated area extends from the north 

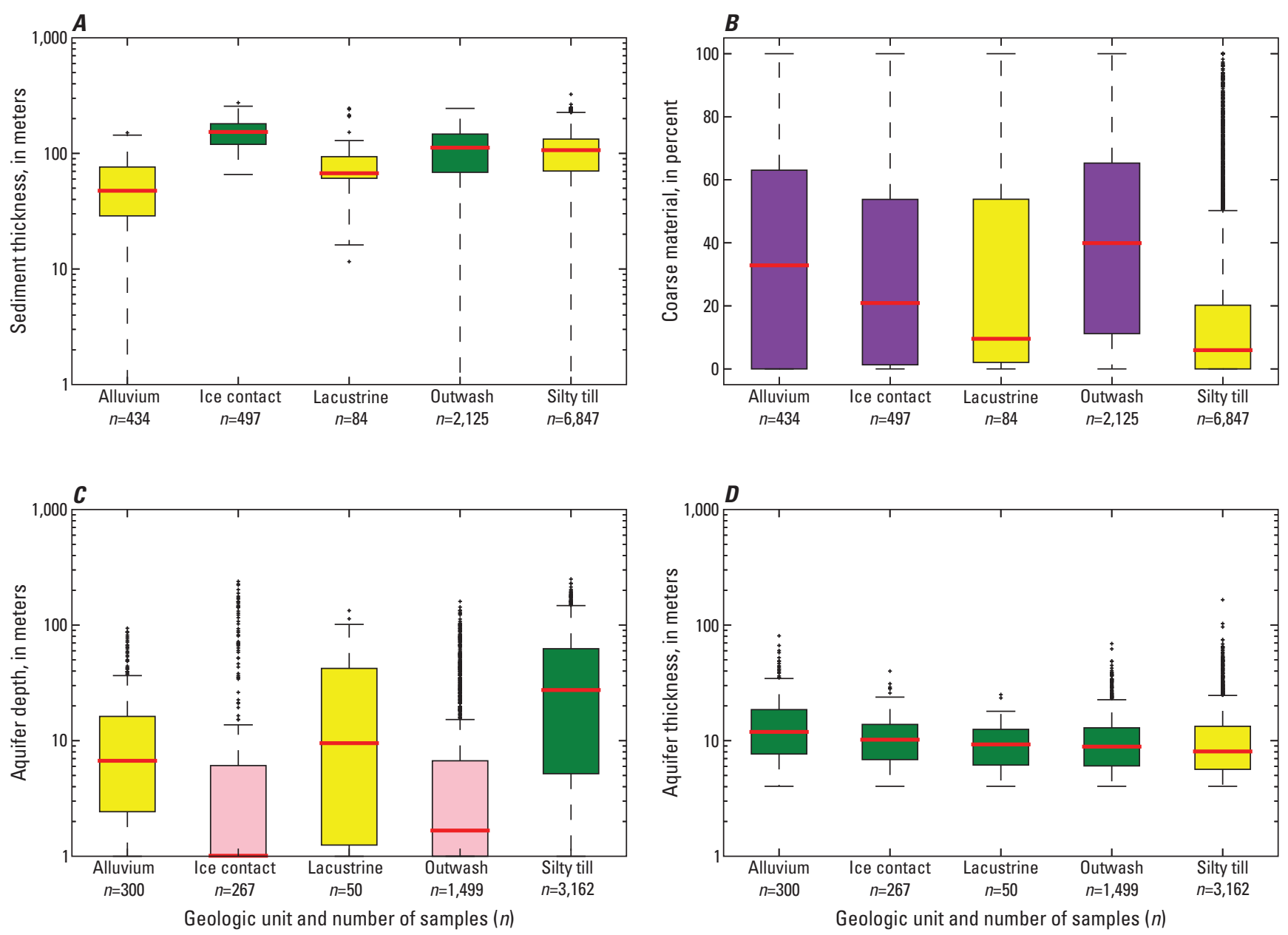

EXPLANATION

$+\quad$ Outlier value - Value is $>1.5$ and $<3$ times the interquartile range beyond either end of the box

Highest value within 1.5 times interquartile range above 75 th percentile

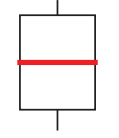
75th percentile

50th percentile (median)

25th percentile

Interquartile range

$\perp \quad$ Lowest value within 1.5 times interquartile range below 25th percentile
Ratio of group median to median value for all data-

For plots with logarithmic axis, group

median is based on log(median)

$<0.5$

0.5 to $<1.0$

1.0 to $<1.5$

1.5 to 2.0

$>2.0$

Figure 45. A, Quaternary thickness, $B$, percent of coarse material, $C$, depth, and $D$, thickness of aquifer-material intervals; and frequency distribution of percentages of material beneath $E$, coarse-textured and $F$, fine-textured map units grouped by map unit in terrane $3 \mathrm{C}$ in the glaciated conterminous United States. 

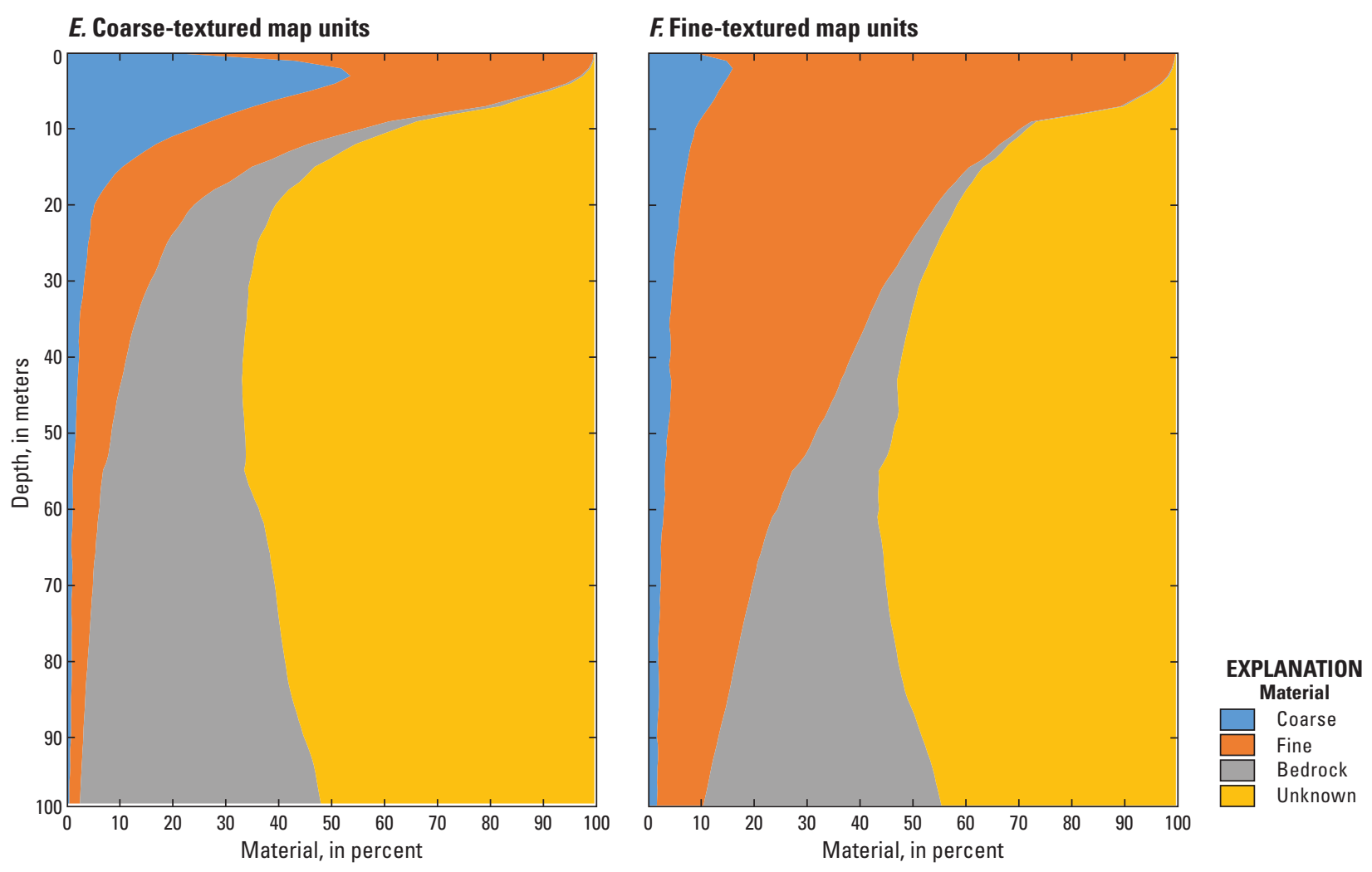

Figure 45. A, Quaternary thickness, $B$, percent of coarse material, $C$, depth, and $D$, thickness of aquifer-material intervals; and frequency distribution of percentages of material beneath $E$, coarse-textured and $F$, fine-textured map units grouped by map unit in terrane $3 \mathrm{C}$ in the glaciated conterminous United States.-Continued

shore to the Ronkonkoma terminal moraine, which bisects the island west to east. Outwash plains that extend south of the moraine to the south shore are excluded in our definition of the glaciated United States. All of Cape Cod is included, however, because geologic units below the Quaternary sediments are not used as aquifers like they are on Long Island. Both areas are blanketed by thick morainal and intermorainal glacial sediment, and some thin postglacial alluvial, organic (peat), and eolian sediments are present in lowland areas. Morainal deposits mark the highest elevations on these islands. Maximum relief is about $93 \mathrm{~m}$ on Cape Cod and about $122 \mathrm{~m}$ on Long Island.

Quaternary sediment on Cape Cod is primarily outwash and ice-contact sand and gravel that directly overlies bedrock. Glacial deposition is the result of the interaction among the Buzzard's Bay, the Cape Cod Bay, and the South Channel ice lobes (Oldale and Barlow, 1986). Deposition from the Buzzard's Bay and the Cape Cod Bay lobes formed the high elevations in the topography of western and northwestern Cape Cod, whereas deposition from the Cape Cod Bay and the South Channel lobes formed the low elevations in the topography of the north-south "arm" of eastern Cape Cod. Outwash plains on Cape Cod cap a deltaic, downward fining sequence (Masterson and others, 1997; Walter and Whealon, 2005). The deltas were deposited into a proglacial lake that was dammed by a moraine near Martha's Vineyard and Nantucket to the south.

Quaternary sediment on Long Island overlies the dissected surface of unconsolidated Cretaceous-age sediments that contain two productive aquifers, the Magothy and the Lloyd aquifers (Smolensky and others, 1989). The Harbor Hill and the Ronkonkoma moraines form the north and south forks of Long Island, respectively, and coalesce into a single moraine across the western third of the island. The moraines are underlain by alternating till and outwash or ice-contact sediments. Intermorainal areas are underlain by outwash and interbedded lacustrine sediments (Krulikas and Kozalka, 1983).

The distribution of map units reflects the differences in glacial deposition that formed Cape Cod and Long Island. Cape Cod is primarily composed of outwash with lesser amounts of ice-contact and eolian sediments (fig. 46A). Long Island is composed of nearly equal parts of ice-contact sediments, till, and outwash, including alluvium and eolian sediments (fig. 46B). Well depths are generally shallower on Cape Cod than on Long Island because Cape Cod has less topographic relief. About 85 percent of wells on Cape Cod are less than $30 \mathrm{~m}$ deep, whereas a similar percentage on Long Island is less than $100 \mathrm{~m}$ deep. The analysis of lithologic logs for Long Island was limited to descriptions of the Quaternary 
sediment, based on a map of sediment thickness obtained from a groundwater-flow model developed for Long Island (Masterson and others, 2016).

The median thickness of Quaternary sediment on Cape Cod is about $100 \mathrm{~m}$ and is less $(70 \mathrm{~m})$ on Long Island (fig. 47A). The median percentage of coarse material in Quaternary sediment on Cape Cod is 100 percent compared with 65 percent on Long Island (fig. 47B). The lower percentages of coarse material on Cape Cod (depicted as outliers on fig. $47 \mathrm{~B}$ ) compared with the percentages of coarse material on Long Island probably reflect the downward fining sequence expected beneath outwash. The frequency distribution of material with depth indicates that coarse materials are shallower on Cape Cod than on Long Island (figs. $47 E, F$ ). The proportion of fine-grained materials in Quaternary sediments is much higher on Long Island than on Cape Cod.

Single aquifer-material intervals are most prevalent on Cape Cod, but multiple intervals are common on Long Island (fig. 48A). The higher percentage of lithologic logs that indicate multiple aquifer-material intervals on Long Island than on Cape Cod reflects the deeper well depths and the presence of fine-grained sediments beneath till and outwash. Median depths of aquifer-material intervals penetrated in logs were $0 \mathrm{~m}$ on Cape Cod (fig. 47C), and $10 \mathrm{~m}$ on Long Island. Median thickness was about $30 \mathrm{~m}$ on Cape Cod and $20 \mathrm{~m}$ on Long Island (fig. 47D). Nearly all water wells on Cape Cod are completed in Quaternary sediment, whereas water wells on Long Island are evenly split between Quaternary and underlying Cretaceous sediment (fig. 48B). Most of these Quaternary wells are unconfined on Cape Cod, but about 60 percent of the Quaternary wells on Long Island are confined (fig. 48C).

\section{Terrane 4B-Eastern Nebraska}

Hydrogeologic terrane 4B consists of coarse-grained, stratified Quaternary sediment in eastern Nebraska (fig. 2C). Sediment was derived from the Laurentide ice sheet to the east and from the glacial and fluvial systems in the Rocky Mountains to the west. Terrane 4B also includes buried, pre-Illinoian till from the Laurentide ice sheet. The western boundary of the terrane is positioned just west of these tills, whose position and geometry is arbitrary; hence, the boundary is approximate and represented on the maps as an undulating line. Alluvium covers 60 percent of the terrane (fig. 25), and silty clayey till covers most of the remainder.

The density of lithologic logs is relatively high (fig. 8), but the usage of wells associated with the logs is not recorded in Nebraska; therefore, data pertaining to water wells are not available. Median thickness of Quaternary sediment in lithologic logs generally ranges from 30 to $80 \mathrm{~m}$ with little variability (fig. 49A). The median percentage of coarse material is highest (75 percent) beneath eolian units (fig. 49B) and ranges from 35 to 55 percent for other units in the terrane. The frequency distribution of material with depth indicates that, beneath coarse-textured map units, about 80 percent of coarse materials are within $54 \mathrm{~m}$ of land surface (fig. 49E). Nearly all lithologic logs penetrated an aquifer-material interval in terrane 4B (fig. 28A), and multiple intervals were penetrated in 45 percent of the logs; three or more intervals were penetrated in 15 percent of the logs. Median depths of aquifer-material intervals penetrated in logs were lowest $(9 \mathrm{~m})$ beneath eolian units (fig. $49 \mathrm{C}$ ) and ranged from 30 to $40 \mathrm{~m}$ for other units in the terrane. Median thickness of aquifer-material intervals ranged from 20 to $30 \mathrm{~m}$ (fig. 49D). Aquifer-material intervals

\section{A. Cape Cod}

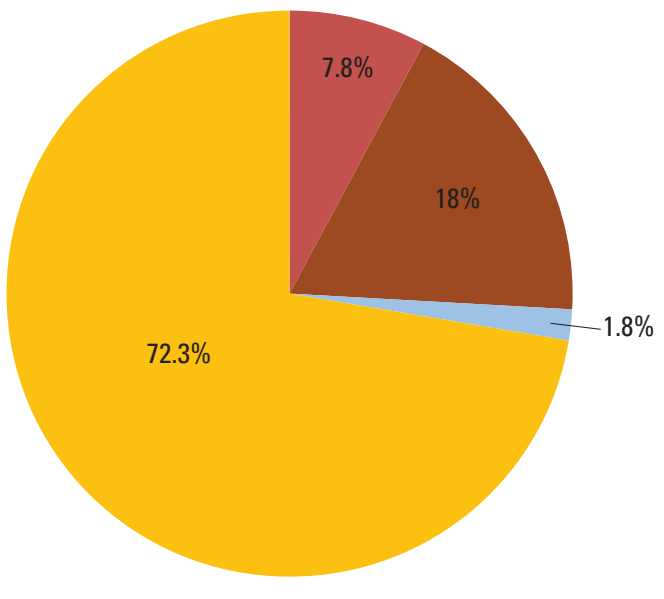

B. Long Island

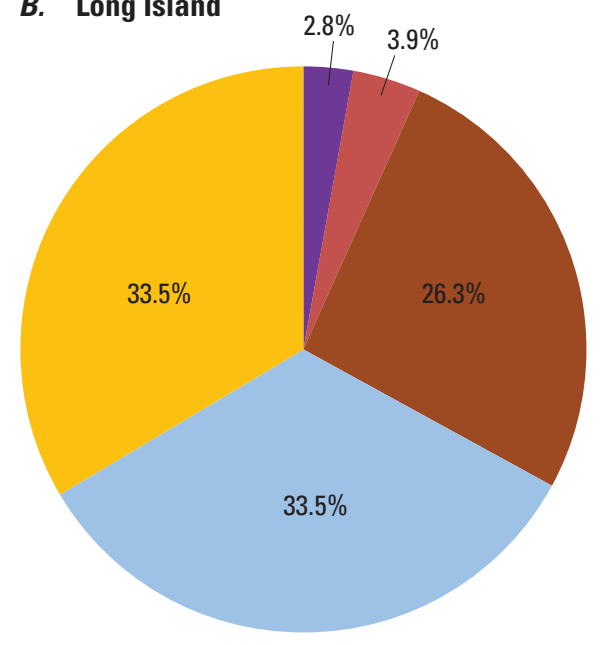

Figure 46. Distributions of map units in terrane $4 \mathrm{~A}$ in the glaciated conterminous United States for $A$, Cape Cod and $B$, Long Island. 

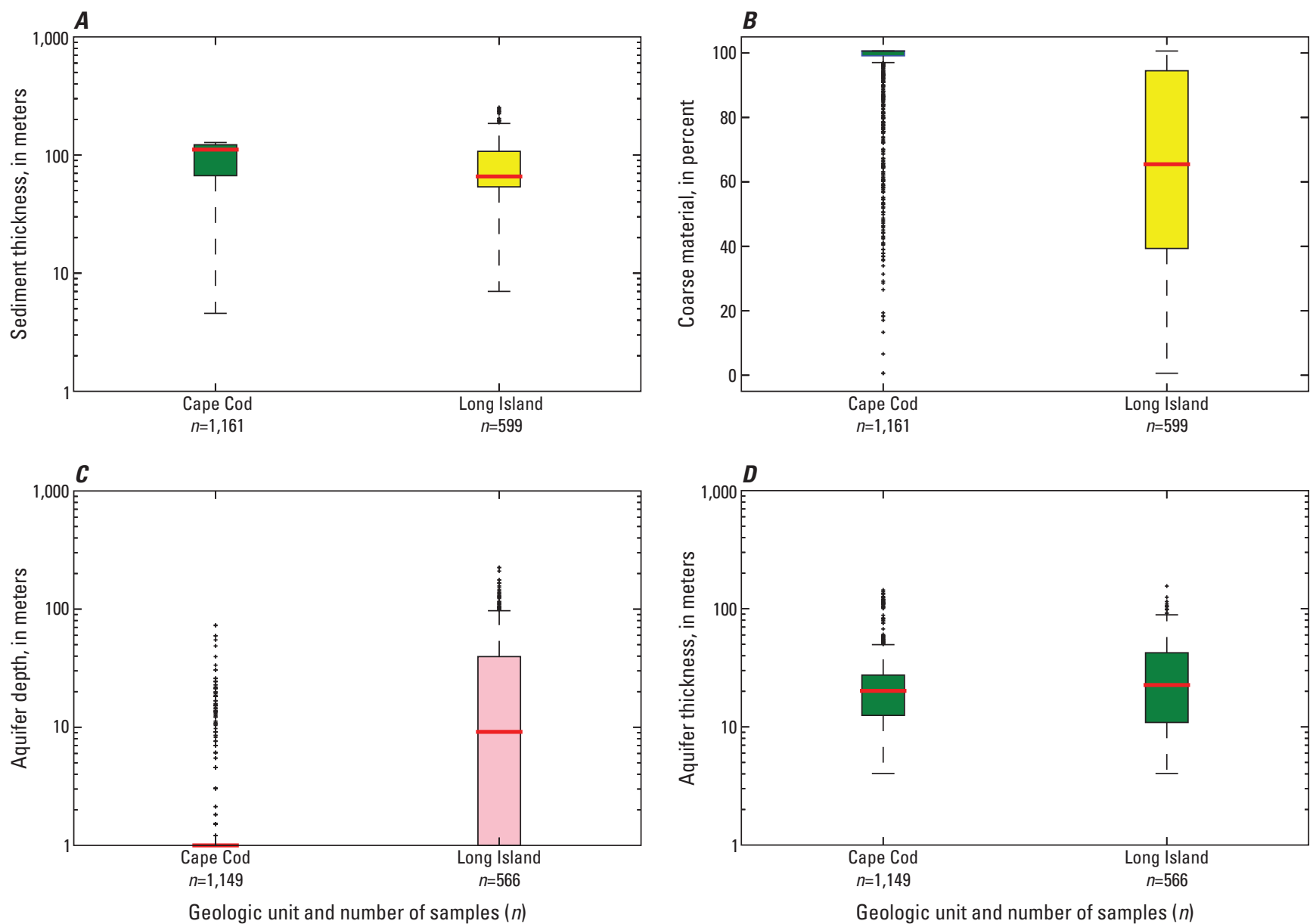

Geologic unit and number of samples $(n)$

\section{EXPLANATION}

$+\quad$ Outlier value - Value is $>1.5$ and $<3$ times the interquartile range beyond either end of the box

$\top$ Highest value within 1.5 times interquartile range

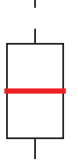
above 75th percentile 75th percentile

50th percentile (median) Interquartile range

25th percentile

Ratio of group median to median value for all data-

For plots with logarithmic axis, group

median is based on log(median)

$\perp \quad$ Lowest value within 1.5 times interquartile range below 25 th percentile

Figure 47. $A$, Quaternary thickness, $B$, percent of coarse material, $C$, depth, and $D$, thickness of aquifer-material intervals; and frequency distribution of percentages of material beneath $E$, Cape Cod and $F$, Long Island grouped by area in terrane $4 A$ in the glaciated conterminous United States. 

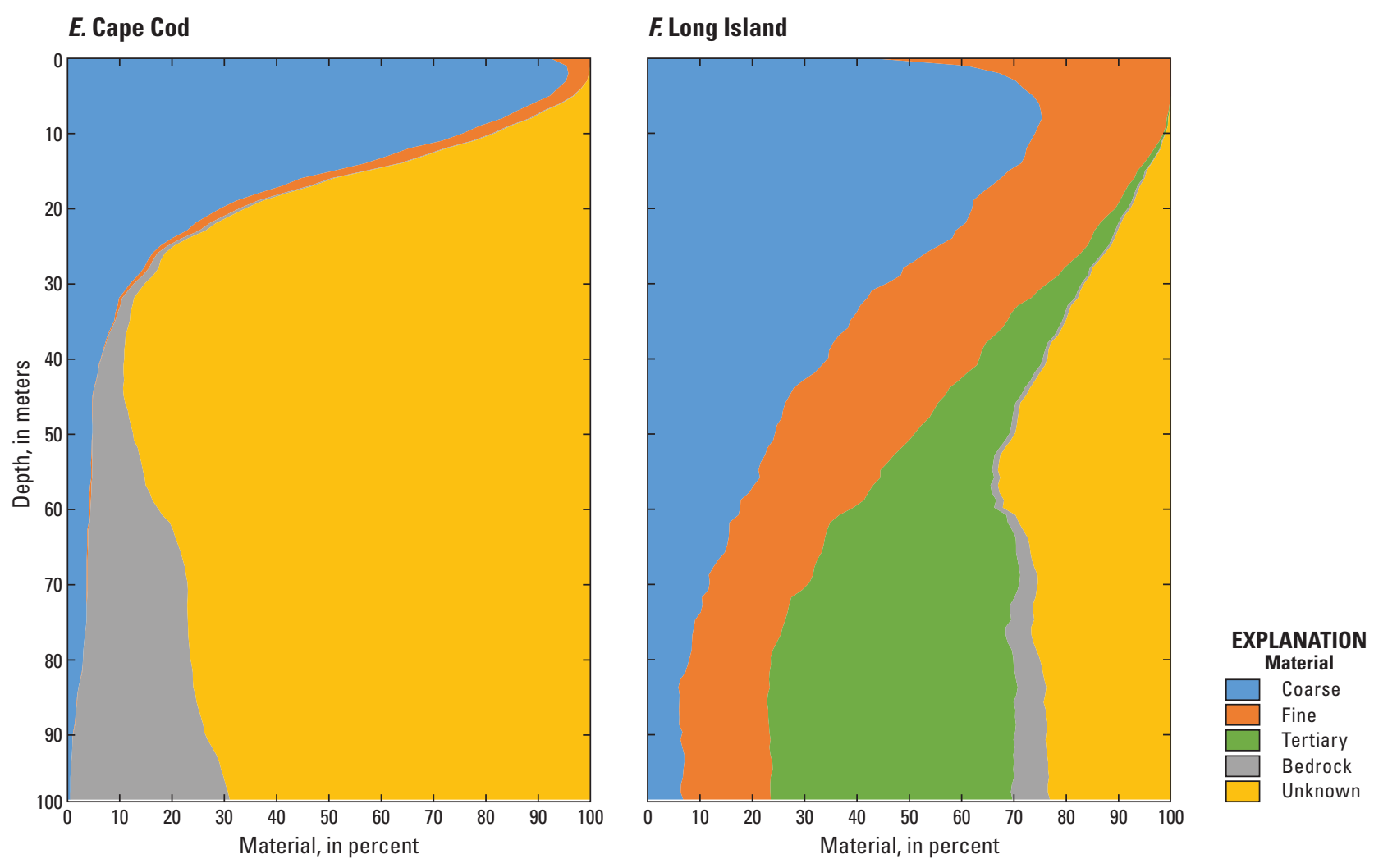

Figure 47. $A$, Quaternary thickness, $B$, percent of coarse material, $C$, depth, and $D$, thickness of aquifer-material intervals; and frequency distribution of percentages of material beneath $E$, Cape Cod and $F$, Long Island grouped by area in terrane $4 A$ in the glaciated conterminous United States.-Continued

are penetrated with a high probability throughout the terrane (fig. 14B) and generally are confined (fig. 20B), except in the valley of the Platte River.

\section{Interpretation of Surficial and Subsurface Data}

The maps and descriptive statistics presented above combine surficial data from geologic mapping with subsurface data from lithologic logs to illustrate characteristics of Quaternary aquifers in different parts of the glaciated United States. The lithologic logs provide one-dimensional depictions of texture data with depth at discrete points. The scale and resolution of this study preclude the correlation of adjacent $\operatorname{logs}$ to obtain three-dimensional representations of Quaternary aquifers within the study area. Nonetheless, aquifer-material intervals identified within the lithologic logs are assumed to correspond to Quaternary aquifers. This assumption is most valid for lithologic logs from Quaternary water wells that presumably produce water from the aquifer-material intervals. The assumption also is reasonable for unconfined aquifermaterial intervals identified in logs from test borings because these are likely to be shallow and connected to sources of recharge, although some zones may be partially unsaturated. The assumption is less certain for confined aquifer-material intervals identified in logs from deep test borings that could be isolated lenses of coarse material that are poorly connected to sources of recharge.

Aquifer-material intervals indicated on maps prepared from the lithologic logs correlate well with aquifer systems delineated on State maps. Selected confined and unconfined aquifer systems in Illinois and Indiana overlay areas where the probability of drilling through an aquifer-material interval is high (fig. 50A). In addition, the Mahomet-Lafayette aquifer system in Illinois and Indiana overlay areas where aquifermaterial intervals are likely to be confined (fig. 50B). The unconfined part of the Mahomet aquifer system west of the limit of Late Wisconsinan glaciation corresponds to an area where aquifer-material intervals are likely to be unconfined, as do the unconfined Kanakee and St. Joseph aquifers in Indiana. The Spiritwood aquifer system in North Dakota, as well as the two smaller Page and Sheyenne deltaic aquifers, overlie areas where the probability of drilling through an aquifer-material interval is high (fig. 51A). The Spiritwood aquifer system and the Page aquifer are largely confined, whereas the Sheyenne 

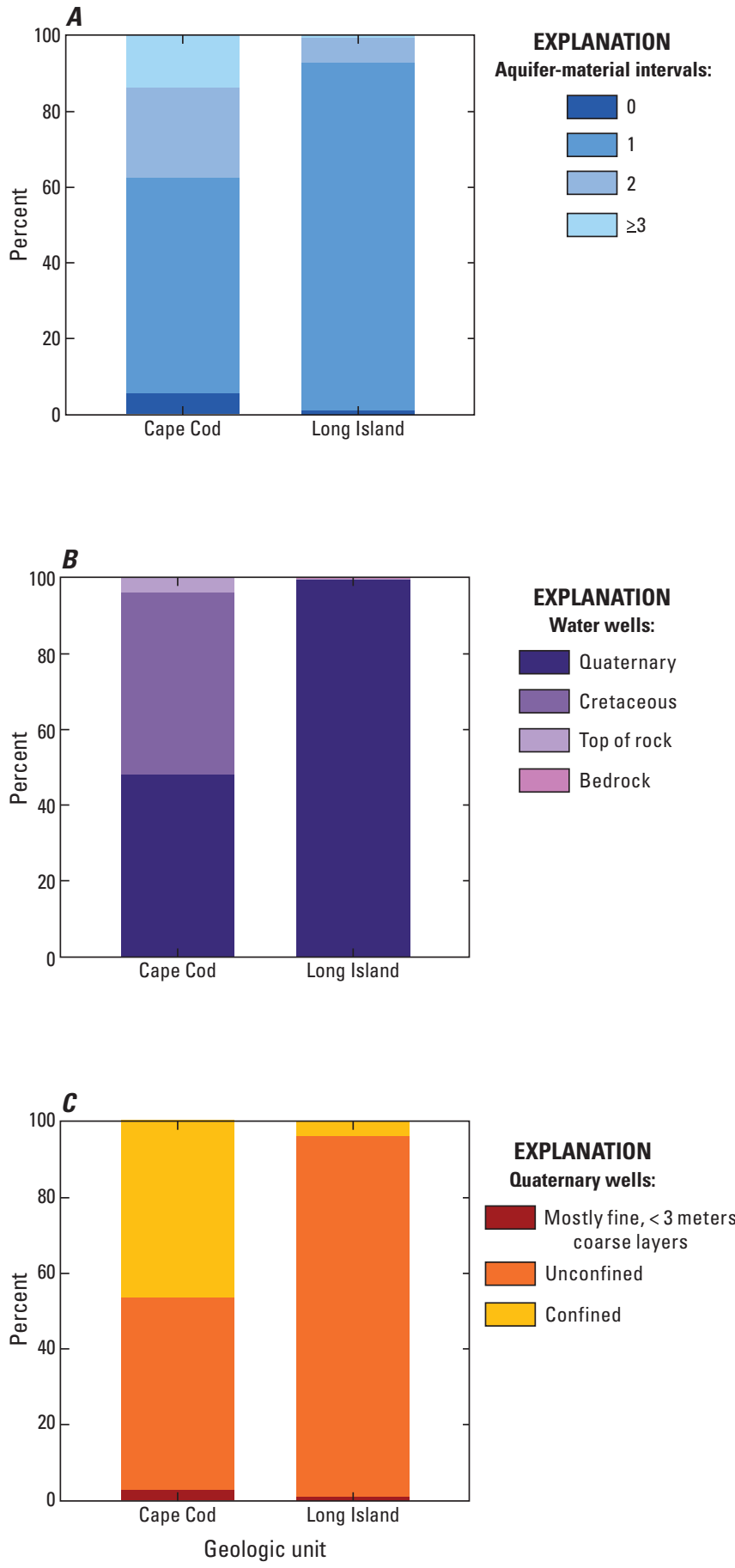

Figure 48. Aquifer characteristics beneath Cape Cod and Long Island in terrane $4 A$ in the glaciated conterminous United States. $A$, Number of aquifers penetrated by lithologic logs. $B$, Water wells completed in Quaternary and Cretaceous sediments, and bedrock. C, Quaternary water wells under confined and unconfined conditions or under mostly fine-grained sediment. aquifer is unconfined, which is consistent with maps showing confined and unconfined aquifer-material intervals (fig. 51B).

The large scale of this study and of the data resources compiled herein limit the resolution at which surficial mapping can be displayed, so some of the mapped features may be located inaccurately. This limitation is particularly apparent in the valleys of the Northeast (terrane 1A) and the Northwest (terrane 1G), where some mapped alluvium units are not aligned along valley thalwegs, as noted in previous sections. Alluvium in some small valleys is not mapped at all on the regional-scale maps used in this report. Data from lithologic logs is aggregated and mapped at the 1-km scale; therefore, local variations in aquifer characteristics (for example, thickness and depth) are averaged over this area. The geometry and extent of Quaternary aquifers are inherently complex as a result of the heterogeneity in texture within the sediments. The mapping and descriptive statistics presented in preceding sections therefore portray a generalized picture of Quaternary aquifers in the glaciated United States.

Figure 50. Selected confined and unconfined aquifers in Illinois and Indiana in the glaciated conterminous United States. $A$, the probability of penetrating at least one aquifer-material interval in lithologic logs. $B$, the conditional probability that the interval, if penetrated by a lithologic log, is in a confined aquifer. Maps are available at https://doi.org/10.3133/sir20185091.

Figure 51. Selected confined and unconfined aquifers in North Dakota in the glaciated conterminous United States. $A$, the probability of penetrating at least one aquifer-material interval in lithologic logs. $B$, the conditional probability that the interval, if penetrated by a lithologic log, is in a confined aquifer. Maps are available at https://doi.org/10.3133/sir20185091.

As noted previously, data from lithologic logs are biased toward shallow depths because not all logs penetrate the entire thickness of Quaternary sediment. These shallow depths are more commonly exploited for water supply, however, so lacking data from deeper parts of the sediment should not limit the utility of the descriptions presented herein, particularly in areas where the sediment is more than $100 \mathrm{~m}$ thick. The density of lithologic logs varies among States, as does the type of information collected for each well. As a result, there are parts of the West and the Northeast where maps of aquifer characteristics (such as thickness and texture) are either based on relatively few data points, or could not be mapped at all (like in Maine). In some terranes, summary statistics are skewed toward data from one or two States, for example, in terrane 1A where logs from Ohio and Vermont account for 50 percent of the total number. 

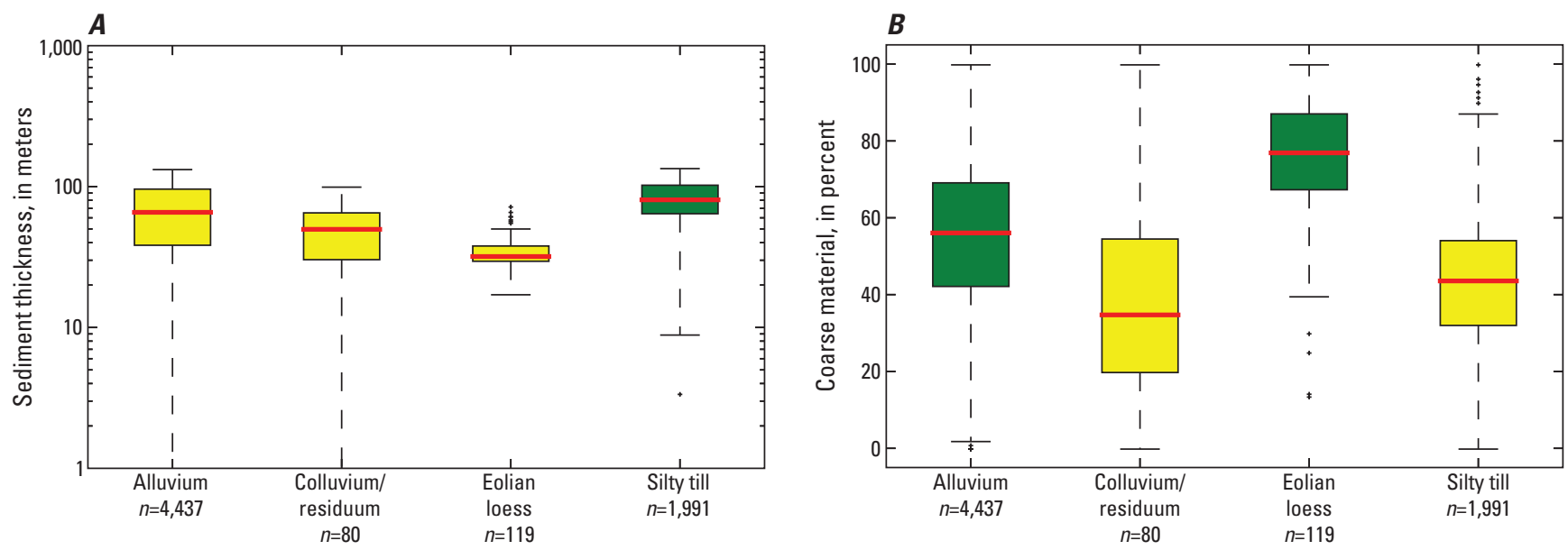

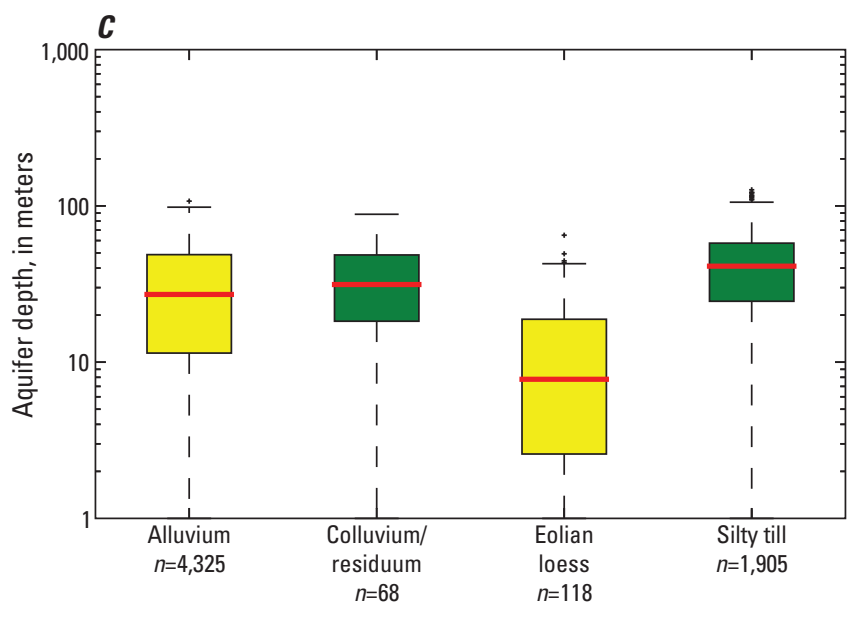

Geologic unit and number of samples $(n)$

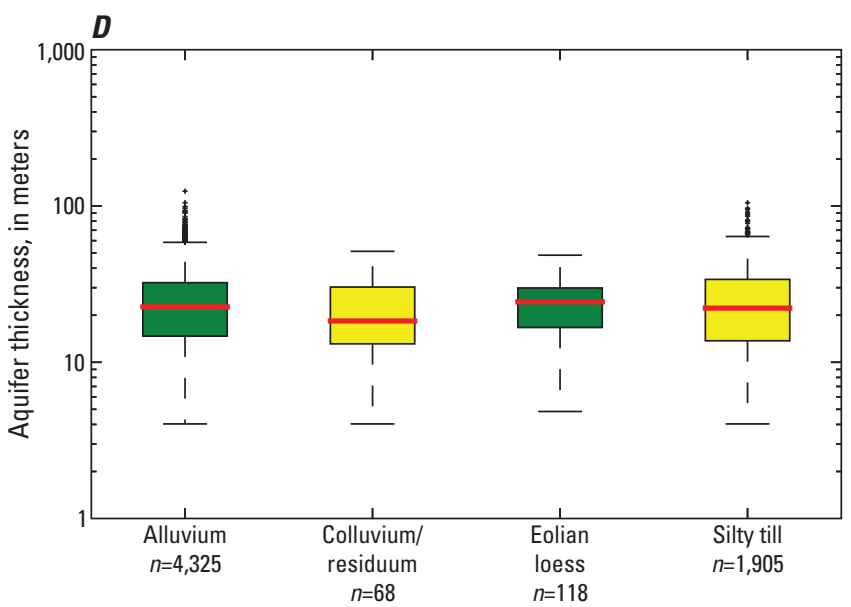

Geologic unit and number of samples $(n)$

EXPLANATION

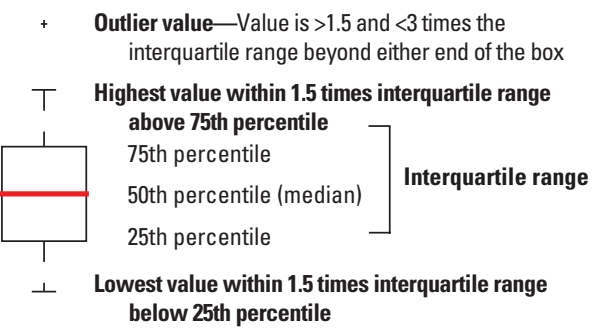

Ratio of group median to median value for all dataFor plots with logarithmic axis, group median is based on log(median)

0.5 to $<1.0$

1.0 to $<1.5$

1.5 to 2.0

$>2.0$

Figure 49. $A$, Quaternary thickness, $B$, percent of coarse material, and, $C$, depth and $D$, thickness of aquifer-material intervals; and frequency distribution of percentages of material beneath $E$, coarse-textured and $F$, fine-textured map units grouped by map unit in terrane $4 \mathrm{~B}$ in the glaciated conterminous United States. 

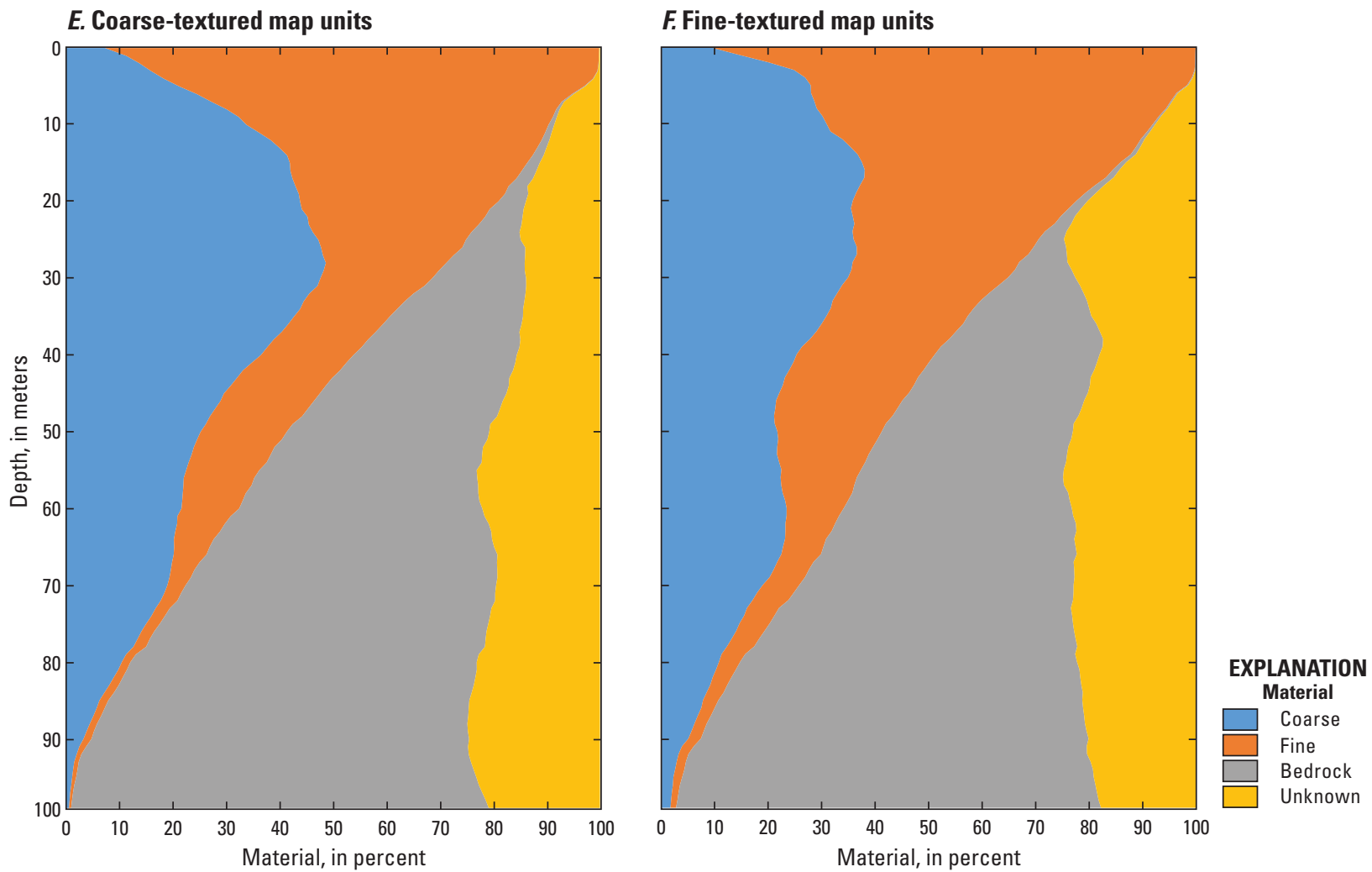

Figure 49. A, Quaternary thickness, $B$, percent of coarse material, and, $C$, depth and $D$, thickness of aquifer-material intervals; and frequency distribution of percentages of material beneath $E$, coarse-textured and $F$, fine-textured map units grouped by map unit in terrane 4B in the glaciated conterminous United States.-Continued

\section{Implications}

A system-wide perspective of the glaciated United States is used in this study to portray the general characteristics of the glacial-aquifer system and to identify distinct regions within it: where the Quaternary sediments are thin and where they are thick, where the aquifers are generally unconfined and where they are confined, and where groundwater is mostly derived from sediment and where it is derived from bedrock. This perspective view complements insights that can be gained from more-detailed mapping of Quaternary sediments and aquifers that are available from State and local studies. Maps and descriptions of glacial geology in each State are available through State Geological Surveys and can be accessed through the Association of American State Geologists (http://www.stategeologists.org/) or through the National Geologic Map Database (https://ngmdb.usgs.gov).

An important contribution of this study is the set of maps derived from information within the lithologic logs that show the regional distributions of texture of the Quaternary sediments, the probability of penetrating one or more aquifermaterial intervals, and the likelihood that the intervals are either unconfined or confined. These maps can serve as an important resource in scoping studies where local data are sparse. The hydrogeologic framework presented herein is the first consistent characterization of the entire glacial-aquifer system for the conterminous United States that crosses State boundaries and combines surficial and subsurface information to provide maps that cover the entire system.

\section{Comparison of Hydrogeologic Terranes}

Descriptive statistics derived from the lithologic database for the hydrogeologic terranes are summarized and compared in table 6. This table presents metrics related to sediment and aquifer characteristics, as well as the distribution of water wells in each terrane. The values presented in the table are taken from figures presented earlier and are of two types: median values from box plots and mean values from bar charts. The values are color coded to highlight similarities and differences among terranes within the table; the individual metric values for each terrane are grouped by color based on similar ranges in ratio to the overall metric value for all terranes. At first glance, there seem to be few similarities among the 17 terranes listed, which is consistent with the original intent of delineating distinct geographic regions within the glaciated United States; however, some similarities are more apparent in a tree diagram compiled from a hierarchical cluster 
analysis based on a dissimilar matrix calculation (fig. 52) using the dissimilarity coefficient of Gower (1971). The tree diagram was chosen because it accounts for missing values, such as water-well information in terrane 4B.

The tree diagram indicates terranes that are similar to each other, as well as terranes or groups of terranes that are quite different from the rest. Terranes $1 \mathrm{G}, 4 \mathrm{~A}$, and $4 \mathrm{~B}$ appear on a separate branch of the tree diagram and are distant from the other terranes. This is expected for terranes $4 \mathrm{~A}$ and $4 \mathrm{~B}$ because the Quaternary sediments in these terranes are thicker and coarser than in the rest of the glaciated United States. Terrane $1 \mathrm{G}$ in the Pacific Northwest is grouped together with 4A and 4B because most of the lithologic logs are near Puget Sound where the Quaternary sediment also is thick and relatively coarse. An alternative tree diagram could be constructed in which data from terrane $1 \mathrm{G}$ were partitioned into three areas (Puget Sound, upland, and valley), as was done for the box plots (fig. 37), possibly resulting in different groupings. This same caveat also applies to terrane $1 \mathrm{~A}$, which was partitioned into upland, lowland, and valley areas (fig. 30). It is difficult to delineate between upland and valley areas in terranes $1 \mathrm{~A}$ and $1 \mathrm{G}$ at the resolution of available mapping, however, so alternative tree diagrams were not constructed.

The next group of terranes that branch from the tree diagram are from the high complexity (prefix " 3 ") group: terranes $3 \mathrm{~A}, 3 \mathrm{~B}$, and $3 \mathrm{C}$. Terranes $3 \mathrm{~A}$ and $3 \mathrm{~B}$ in Michigan and Minnesota, respectively, seem to be most similar from the analysisboth have comparable, complex depositional histories, but there are also differences in sediment characteristics (table 6). Terrane $3 \mathrm{C}$ in the Prairie Coteau has some characteristics that are most similar with terrane $3 \mathrm{~A}$ and others most similar to terrane 3B. All three terranes have mainly Quaternary water wells that are likely confined and only penetrate less than half the sediment thickness.

The next pair that branches from the tree diagram are terranes $2 \mathrm{C}$ and $2 \mathrm{D}$ in parts of Iowa and Minnesota. The sediments in these terranes are quite similar. Aquifer-material intervals are deeper in terrane $2 \mathrm{C}$, however, which is adjacent to the high complexity terranes $3 \mathrm{~B}$ and $3 \mathrm{C}$. Quaternary wells are more likely in terrane $2 \mathrm{C}$ than in terrane $2 \mathrm{D}$, and they are more likely confined.

The remaining terranes comprise the two middle branches in the tree diagram. One branch includes terranes from the lower complexity (prefix "1") group: 1A, 1B, 1C, 1D, and 1E. These terranes include the Northeast, areas south of the limit of Late Wisconsinan glaciation in the Midwest, the Driftless area, and areas adjacent to Lake Superior. They consist mainly of fine sediment and have relatively few shallow aquifers. Most water wells in this group are in bedrock, and the Quaternary water wells are mostly shallow and unconfined, and penetrate most of the sediment thickness. In contrast, terranes $1 \mathrm{~F}$ in Montana and Dakotas and $1 \mathrm{G}$ in the Northwest are distinct from the other low complexity terranes in the tree diagram.
The remaining terranes $1 \mathrm{~F}, 2 \mathrm{~A}, 2 \mathrm{~B}$, and $2 \mathrm{E}$ cover a broad swath of the glaciated United States from Ohio through Illinois and into Wisconsin, the Dakotas, and Montana. Terranes $1 \mathrm{~F}, 2 \mathrm{~A}$, and $2 \mathrm{E}$ consist of mostly fine sediment, where thin, shallow aquifer-material intervals are likely, whereas sediment is coarser in terrane $2 \mathrm{~B}$ and aquifer-material intervals are thicker (table 6). Quaternary water wells in all four terranes are common but more likely unconfined in terrane $2 \mathrm{~B}$. Terranes $1 \mathrm{~F}$ and $2 \mathrm{E}$ contain sediment derived from the same ice sheet in Montana and the Dakotas.

\section{Applications of Hydrogeologic Framework}

This hydrogeologic framework can be used in ongoing studies that are part of the USGS water-quality assessment for the glaciated United States. Three-dimensional, groundwater flow models are currently being prepared at the 8-digit hydrologic unit code scale for tens of watersheds in the glaciated United States to estimate groundwater residence times in the Quaternary sediments (Jeffrey J. Starn, U.S. Geological Survey, written commun., 2017). Data provided by this framework will be used in constructing these models, such as the texture and thickness of Quaternary sediments to represent hydraulic conductivity and transmissivity. The depth of aquifer-material intervals, and areas of confined and unconfined aquifers, will be used to design the layering assigned to the flow models. In addition, metamodels that are based on the flow modeling results can incorporate the hydrogeologic terrane classification as a surrogate for variables that have not been mapped system-wide, such as vertical hydraulic conductivity. Preliminary results indicate that hydrogeologic terrane is a significant variable in the prediction of groundwater residence-time distributions (Jeffrey J. Starn, U.S. Geological Survey, written commun., 2018).

The hydrogeologic framework in this report was prepared to enable comparisons of water-quality constituents in the glaciated United States. Previous studies have determined that variations in the concentrations of inorganic ions and nutrients, and some trace elements, in groundwater within Quaternary sediments are the result of natural variations in the geologic environment (Arnold and others, 2008; Best and others, 2015); for example, sediment texture controls the rate of groundwater flow and the length of time water is in contact with aquifer material, with faster flow through coarser-grained materials. Oxidation-reduction reactions that control the fates of nitrate and arsenic in groundwater are affected by the availability of dissolved oxygen, which in turn may be determined by the confined or unconfined nature of the aquifers. The terrane classification in the hydrogeologic framework reflects the sediment texture and the degree of aquifer confinement and will likely contribute to the explanation of variations in groundwater quality across the glaciated United States. 
Table 6. Comparison of aquifer material and water-well metrics from lithologic database for the glaciated conterminous United States.

[Colors are based on ratio of each terrane measurement to overall value. Ratios of thickness and depth measurements are based on log values. Depth to 80 percent is the depth above which 80 percent of coarse material occurs. Percent encountered is the percentage of logs containing aquifer-material intervals. Percent Quaternary is the percentage of water wells screened in Quaternary sediments. Percent sediment thickness is the Quaternary well depth as a percentage of sediment thickness. m, meter; <, less than; >, greater than; - , no data]

\begin{tabular}{|c|c|c|c|c|c|c|}
\hline \multirow{3}{*}{ Terrane } & \multicolumn{6}{|c|}{ Sediment characteristics } \\
\hline & \multicolumn{2}{|c|}{ Median thickness } & \multicolumn{2}{|c|}{ Median percent coarse material } & \multicolumn{2}{|c|}{ Depth to 80 percent coarse material } \\
\hline & $\begin{array}{c}\text { Measurement } \\
(\mathrm{m})\end{array}$ & Ratio & Percentage & Ratio & $\begin{array}{c}\text { Measurement } \\
(\mathrm{m})\end{array}$ & Ratio \\
\hline $1 \mathrm{~A}$ & 8.8 & $0.5-1.0$ & 13.6 & $0.5-1.0$ & 21.5 & $0.5-1.0$ \\
\hline 1B & 15.2 & $0.5-1.0$ & 3.7 & $<0.5$ & 23.6 & $0.5-1.0$ \\
\hline $1 \mathrm{C}$ & 12.8 & $0.5-1.0$ & 0.0 & $<0.5$ & 19.9 & $0.5-1.0$ \\
\hline $1 \mathrm{E}$ & 13.9 & $0.5-1.0$ & 30.3 & $1.5-2.0$ & 17.8 & $0.5-1.0$ \\
\hline $1 \mathrm{~F}$ & 21.3 & $0.5-1.0$ & 17.9 & $1.0-1.5$ & 28.0 & $1.0-1.5$ \\
\hline $1 \mathrm{G}$ & 50.2 & $1.0-1.5$ & 35.6 & $1.5-2.0$ & 53.3 & $>2.0$ \\
\hline $2 \mathrm{~A}$ & 29.7 & $1.0-1.5$ & 15.1 & $0.5-1.0$ & 25.8 & $1.0-1.5$ \\
\hline $2 \mathrm{~B}$ & 33.5 & $1.0-1.5$ & 53.1 & $>2.0$ & 20.4 & $0.5-1.0$ \\
\hline $3 \mathrm{~A}$ & 78.3 & $1.0-1.5$ & 42.6 & $>2.0$ & 19.3 & $0.5-1.0$ \\
\hline $3 \mathrm{~B}$ & 71.4 & $1.0-1.5$ & 25.4 & $1.0-1.5$ & 25.7 & $1.0-1.5$ \\
\hline $3 \mathrm{C}$ & 107.6 & $1.0-1.5$ & 10.3 & $0.5-1.0$ & 20.0 & $0.5-1.0$ \\
\hline $4 \mathrm{~A}$ & 86.9 & $1.0-1.5$ & 92.3 & $>2.0$ & 34.9 & $1.0-1.5$ \\
\hline $4 \mathrm{~B}$ & 71.2 & $1.0-1.5$ & 51.8 & $>2.0$ & 54.9 & $>2.0$ \\
\hline Overall & 29.3 & - & 19.1 & - & 24.6 & - \\
\hline
\end{tabular}

\begin{tabular}{|c|c|c|c|c|c|c|}
\hline \multirow{3}{*}{ Terrane } & \multicolumn{6}{|c|}{ Aquifer-material interval characteristics } \\
\hline & \multicolumn{2}{|c|}{ Mean percent encountered } & \multicolumn{2}{|c|}{ Median depth } & \multicolumn{2}{|c|}{ Median thickness } \\
\hline & Percentage & Ratio & $\begin{array}{l}\text { Measurement } \\
\text { (m) }\end{array}$ & Ratio & $\begin{array}{l}\text { Measurement } \\
\text { (m) }\end{array}$ & Ratio \\
\hline $1 \mathrm{~A}$ & 25.0 & $<0.5$ & 0.0 & $<0.5$ & 10.8 & $0.5-1.0$ \\
\hline $1 \mathrm{~B}$ & 25.5 & $<0.5$ & 5.7 & $0.5-1.0$ & 11.7 & $1.0-1.5$ \\
\hline $1 \mathrm{C}$ & 17.9 & $<0.5$ & 7.6 & $1.0-1.5$ & 11.7 & $1.0-1.5$ \\
\hline $1 \mathrm{E}$ & 49.3 & $0.5-1.0$ & 0.2 & $<0.5$ & 11.3 & $1.0-1.5$ \\
\hline $1 \mathrm{~F}$ & 45.9 & $0.5-1.0$ & 7.1 & $0.5-1.0$ & 9.7 & $0.5-1.0$ \\
\hline $1 \mathrm{G}$ & 67.9 & $1.0-1.5$ & 17.4 & $1.0-1.5$ & 15.3 & $1.0-1.5$ \\
\hline $2 \mathrm{~A}$ & 51.4 & $0.5-1.0$ & 11.1 & $1.0-1.5$ & 9.7 & $0.5-1.0$ \\
\hline $2 \mathrm{~B}$ & 81.9 & $1.0-1.5$ & 4.6 & $0.5-1.0$ & 15.1 & $1.0-1.5$ \\
\hline $3 \mathrm{~A}$ & 77.2 & $1.0-1.5$ & 4.7 & $0.5-1.0$ & 11.7 & $1.0-1.5$ \\
\hline $3 B$ & 79.4 & $1.0-1.5$ & 18.6 & $1.0-1.5$ & 10.1 & $0.5-1.0$ \\
\hline $3 \mathrm{C}$ & 51.2 & $0.5-1.0$ & 10.7 & $1.0-1.5$ & 8.7 & $0.5-1.0$ \\
\hline $4 \mathrm{~A}$ & 97.4 & $1.5-2.0$ & 0.6 & $<0.5$ & 20.9 & $1.0-1.5$ \\
\hline $4 B$ & 91.8 & $1.5-2.0$ & 30.5 & $1.5-2.0$ & 22.6 & $1.0-1.5$ \\
\hline Overall & 54.8 & - & 7.6 & - & 11.3 & - \\
\hline
\end{tabular}


Table 6. Comparison of aquifer material and water-well metrics from lithologic database for the glaciated conterminous United States. - Continued

[Colors are based on ratio of each terrane measurement to overall value. Ratios of thickness and depth measurements are based on log values. Depth to 80 percent is the depth above which 80 percent of coarse material occurs. Percent encountered is the percentage of logs containing aquifer-material intervals. Percent Quaternary is the percentage of water wells screened in Quaternary sediments. Percent sediment thickness is the Quaternary well depth as a percentage of sediment thickness. m, meter; <, less than; >, greater than; - , no data]

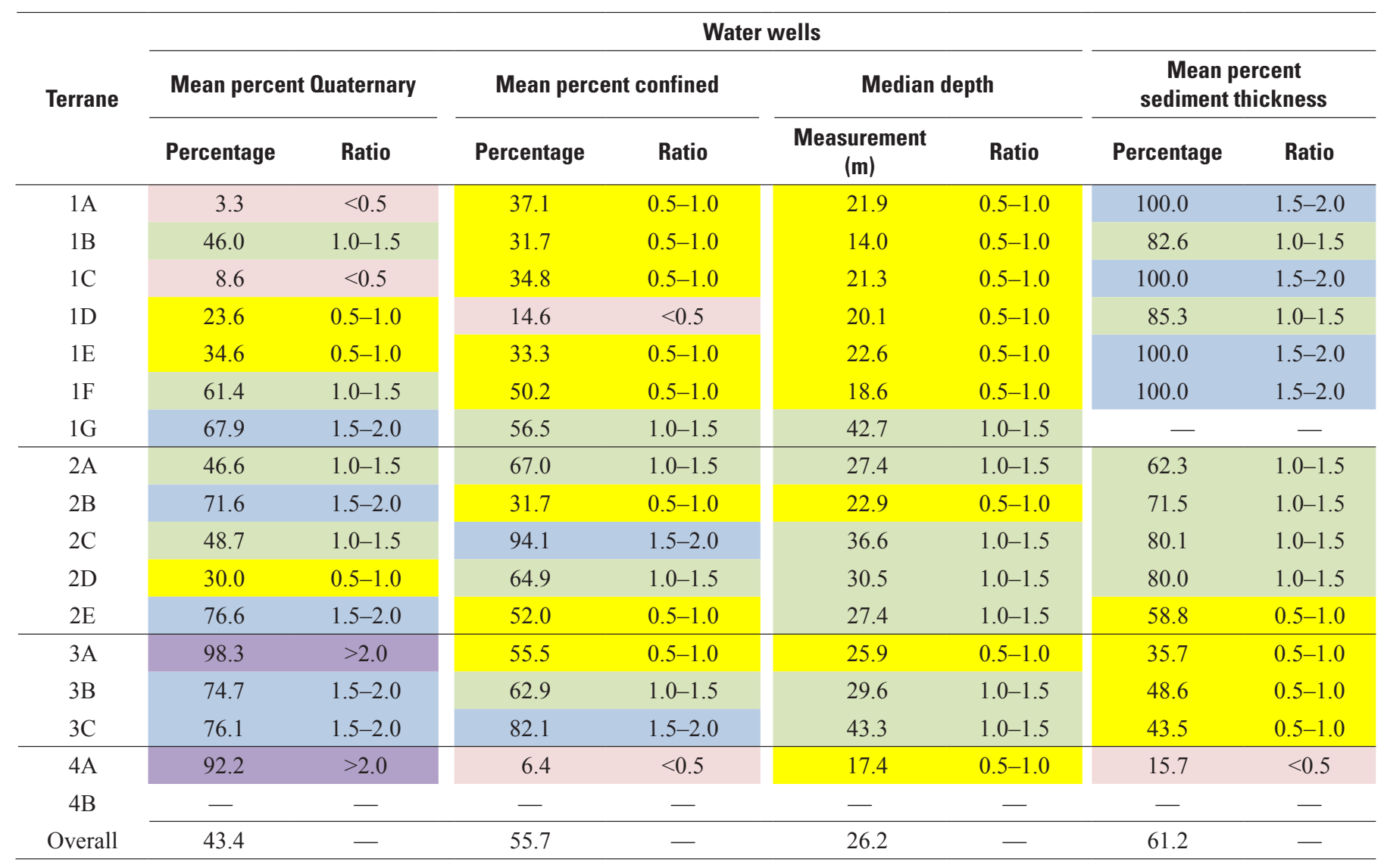




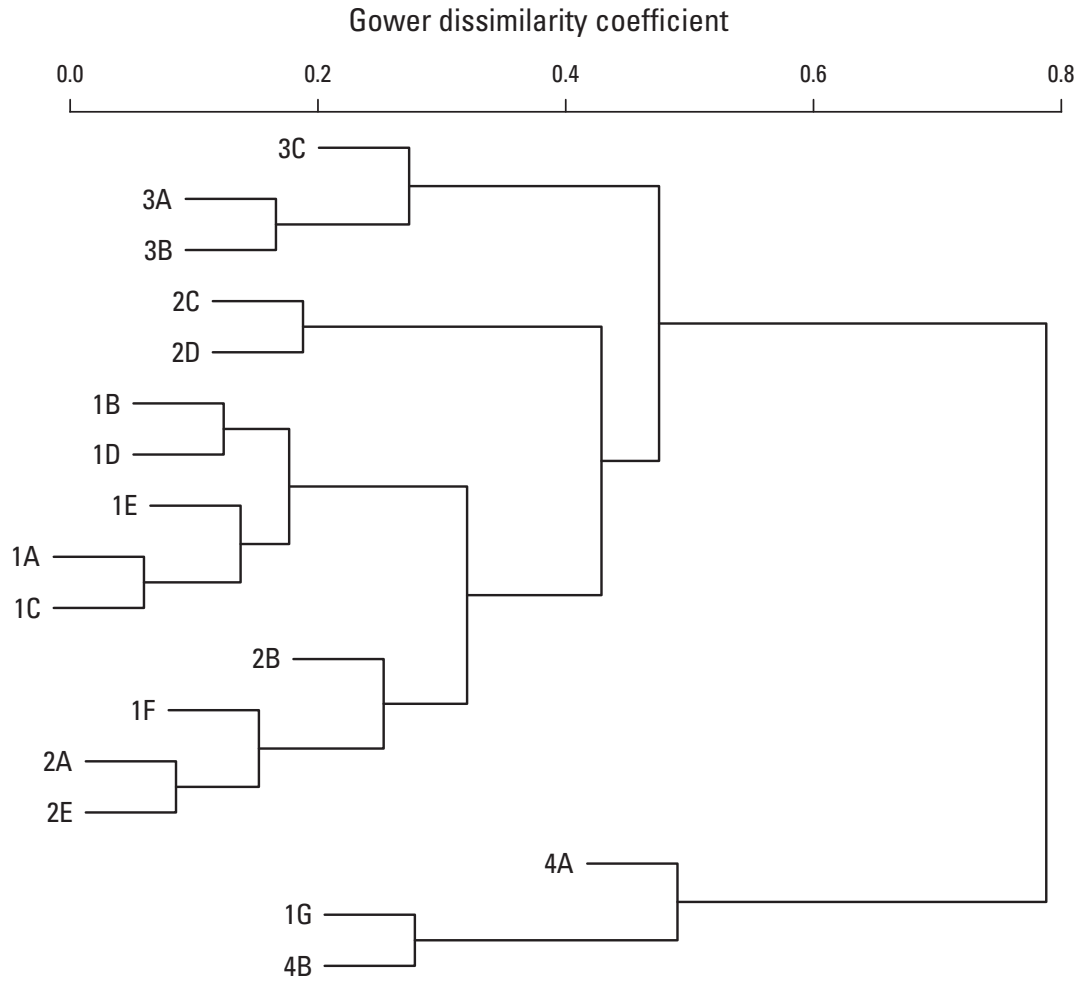

Figure 52. Similarities and dissimilarities among hydrogeologic terranes in the glaciated conterminous United States, based dissimilar matrix calculation of the metrics listed in table 6 .

\section{Summary}

The glacial aquifer system, the collection of aquifers within Quaternary sediments in the glaciated conterminous United States, is a principal aquifer that supplies groundwater withdrawals that account for about 5 percent of the Nation's drinking water. In this study the glaciated United States refers to Quaternary sediment north of the line of maximum glacial advance in the conterminous United States. This area includes parts of 25 States and covers $1.87 \times 10^{6}$ square kilometers $\left(\mathrm{km}^{2}\right)$. This report presents a hydrogeologic framework that characterizes the properties and extents of aquifers in the glaciated United States for use in the development of modeling tools to estimate groundwater quality and vulnerability in areas without sampled data.

The hydrogeologic framework presented herein divides the glaciated United States into 17 distinct terranes, each of which contains Quaternary sediment that is derived from a common depositional history and can be characterized by texture and thickness. A geologically based approach was used to delineate the hydrogeologic terranes based on an interpretation of existing geologic mapping of surficial and Quaternary deposits and on thickness of unconsolidated material. Characteristics of aquifer materials in Quaternary sediment are described using attributes computed from a lithologic database of well logs compiled from 24 States (excluding Kentucky). Aquifer-material characteristics are portrayed graphically and are mapped to provide a generalized spatial representation of these characteristics across the aquifer system.
This hydrogeologic framework is not intended as an exhaustive and detailed study of aquifers in the glaciated United States and does not provide detailed characterizations of aquifers that are commonly presented in site-specific or regional studies. Rather, the framework presents a comprehensive nationwide picture of the glacial aquifer system through maps and graphical depictions of data obtained from lithologic logs. The delineation of hydrogeologic terranes allows generalizations concerning the nature of aquifers (for example, whether the aquifers are shallow or deep, and unconfined or confined). The hydrogeologic framework also facilitates comparisons between characteristics of Quaternary sediments and aquifer properties in terranes in different parts of the glaciated United States. In this way, insights can be gained from understanding the similarities and differences in distinct parts of the aquifer system, and their relation to water quality and aquifer vulnerability.

\section{Data Sources}

\section{Hydrogeologic Terranes}

The geologic framework controls the occurrence and geometry of aquifers and whether or not they might provide a useable supply of groundwater. Classification of areas within the glaciated United States was designed to address the potential for penetrating coarse-grained materials (for example, sand and gravel) in the subsurface that might, given an adequate 
influx of water, serve as aquifers. These hydrogeologic terranes were defined on the basis of the following:

- overall thickness of Quaternary-age sediment,

- the predominant modes of glacial deposition,

- the predominant texture of the geologic materials at land surface, and

- the age of deposition.

The first criterion was used to qualitatively rank the generalized complexity of geologic framework in each terrane: "low" complexity (assigned a terrane code $=1$ ), "moderate" (terrane code $=2$ ), and "high" complexity (terrane code $=3$ ). To differentiate terranes of similar complexity, letter designations were appended to the numeric codes (for example, terranes $1 \mathrm{~A}$ or $3 \mathrm{C}$ ). Two unique areas, where thick, stratified, coarsegrained sediment dominates, were assigned terrane code $=4$.

\section{Surficial Geology}

Map units based on the depositional environment, sediment texture and character, and geomorphic expression of the surficial sediments were combined from two published mapping reports: the U.S. Geological Survey (USGS) Quaternary Atlas Series and a Surficial Materials Map. The principal map units are mapped in the Glacial Environments and Surficial Sediments geodatabase (GESS) using a consistent terminology.

\section{Bedrock Geology}

A generalized map of the bedrock geology underlying the glaciated conterminous United States was compiled from state geologic maps to indicate the local provenance of glacial sediment, and where Quaternary aquifers could be in contact with bedrock aquifers.

\section{Lithologic Database}

A lithologic database for the glaciated United States compiled from State well records used for this study contains 1,565,349 lithologic logs, of which 740,727 are from water wells. Several metrics that characterize the Quaternary sediment and aquifer materials penetrated by the wells were computed from the lithologic logs. The sediment was classified into fine (clay and silt) and coarse (fine sand to gravel) categories. Potential aquifer material was considered to be greater than or equal to 3 meters $(\mathrm{m}$ ) of continuous coarse material and could include layers of fine materials as much as $1.5 \mathrm{~m}$ thick. Water wells were classified as Quaternary wells or bedrock wells, based on the well depth and the thickness of Quaternary sediment. Not all wells penetrated the entire thickness of Quaternary sediment, especially in areas where the sediment is thickest, so in some areas maps derived from these metrics are biased toward data from shallow wells.

\section{Recharge}

The magnitude and distribution of recharge computed by the soil-water balance (SWB) model for the glaciated conterminous United States reflects the variability in climate and the distribution of Quaternary sediment at land surface across the area. The median recharge is 136 millimeters per year ( $\mathrm{mm} / \mathrm{yr}$ ), but ranges from more than $400 \mathrm{~mm} / \mathrm{yr}$ in the Northeast (terranes 1A and 4A) to $11 \mathrm{~mm} / \mathrm{yr}$ or less in the upper Midwest (terranes 1F and 2E). The distribution of recharge estimated by this study is compared to two recharge maps recently prepared by other studies. All 3 maps compare favorably with estimated base flow at more than 400 gaged watersheds in the glaciated United States. The distribution of recharge estimated by this study reflects the surficial geology by predicting more recharge in lowland areas with coarsegrained sediments and less recharge in upland areas with fine-grained sediments. The comparison with estimated base flows indicates more spatial bias in the recharge map from this study, however.

\section{Groundwater Usage}

Public-supply records of groundwater usage were collected for parts of 24 States within the glaciated United States (excluding Kentucky) for water systems that withdraw groundwater through wells and springs. Water-use records obtained for 71,566 systems include the ownership and type of public-water system, the location and the population served by the system, the withdrawal rates for the reporting years 2009 to 2013, the well construction data, and the source aquifer of the water supply. This effort required cross-referencing information from several State and Federal databases. Annual groundwater withdrawals compiled by county range from less than 1 to greater than $370 \mathrm{~mm} / \mathrm{yr}$, with a mean of $7.4 \mathrm{~mm} / \mathrm{yr}$ on an areal basis. About 37 percent of the withdrawals are for public-water supply, of which 60 percent are derived from Quaternary sediments. Groundwater withdrawals account for less than 10 percent of recharge throughout most the glaciated United States, but for a greater part of recharge near urban areas in the Northeast and the Midwest, and in counties throughout dry parts of the Midwest.

\section{Quaternary Sediment and Aquifers}

Quaternary sediment at land surface in the glaciated United States includes glacial sediment deposited during the Late Wisconsinan glaciation, pre-Late Wisconsinan sediments in parts of the Midwest, and postglacial alluvium in stream valleys. The surficial sediment is mainly till (60 percent of land area covered). Large areas of outwash and ice contact sediments are preserved mainly within areas of Wisconsinan glaciation and are extensive throughout the Midwest but generally are confined to valleys in the Northeast and the Northwest. Lacustrine sediments commonly were deposited 
in proglacial lakes, most prominently adjacent to the present Great Lakes, and in glacial Lake Agassiz in the eastern Dakotas and northwestern Minnesota.

Box plots and maps derived from metrics computed from the lithologic data illustrate characteristics of the subsurface sediment including the thickness of Quaternary sediment, the percentage of coarse material, and the proportion of coarse material with depth. The median thickness of Quaternary sediment ranges from 9 to $108 \mathrm{~m}$ across the 17 hydrogeologic terranes, but the maximum thickness is more than $500 \mathrm{~m}$ in some areas. Throughout most of the glaciated United States, Quaternary sediments generally contain less than 10 percent coarse material, but the percentage is highly variable and ranges from a median value near zero percent under till to 50 percent under ice-contact and outwash sediments. About 80 percent of the coarse material lies within 25 to $40 \mathrm{~m}$ of land surface.

In many areas of the glaciated United States, there is a small likelihood of penetrating aquifer material at least $3 \mathrm{~m}$ thick. A single aquifer-material interval was recorded in about 44 percent of the lithologic logs, whereas about 11 percent of the logs penetrated multiple intervals. The depths of the aquifer-material intervals are highly variable; median depths range from less than $3 \mathrm{~m}$ under ice-contact and outwash sediments to $18 \mathrm{~m}$ under clayey till. The range of thicknesses of aquifermaterial intervals is less variable, and median thicknesses range from $10 \mathrm{~m}$ under clayey till to $20 \mathrm{~m}$ under alluvium. About 44 percent of water wells in the glaciated United States are completed in Quaternary sediment, and about 8 percent are completed within $7.5 \mathrm{~m}$ of the bedrock surface, suggesting these wells produce groundwater from the sediment and bedrock. Most of the Quaternary water wells (42 percent) are confined by at least $7.5 \mathrm{~m}$ of fine materials, whereas about 33 percent are unconfined - the remainder are where only thin layers of coarse material (less than $3 \mathrm{~m}$ ) are present. The median depths of Quaternary water wells range from 13 to $40 \mathrm{~m}$ among the 17 hydrogeologic terranes.

\section{Characteristics of Hydrogeologic Terranes}

The salient characteristics of the 17 hydrogeologic terranes are presented through maps and a set of descriptive plots to facilitate visual comparisons between selected sediment and aquifer characteristics. The thickness of Quaternary sediment generally increases from the lower complexity terranes through the higher complexity terranes, consistent with the delineation of the terranes. The proportion of coarse material in Quaternary sediment is highly variable; several terranes (2B, 3A, 4A, and 4B) contain a much larger percentage of coarse-grained sediment (median value greater than 40 percent) than others (median value less than 10 percent; 1A, 1B, $1 \mathrm{C}, 1 \mathrm{D}$, and 2C). The depths to aquifer-material intervals also are highly variable; several terranes $(1 \mathrm{~A}, 1 \mathrm{D}, 1 \mathrm{E}$, and $4 \mathrm{~A}$ ) have median depths of zero or less than $1 \mathrm{~m}$, indicating that most intervals begin at land surface and hence are unconfined. In contrast, two terranes ( $2 \mathrm{C}$ and $4 \mathrm{~B}$ ) have median depths approaching $30 \mathrm{~m}$, indicating that most intervals probably are confined. The median thicknesses of aquifer-material intervals generally fall within a narrow range of 10 to $20 \mathrm{~m}$, except in terranes $4 \mathrm{~A}$ and $4 \mathrm{~B}$ where median thicknesses $(20 \mathrm{~m}$ or more) are consistent with their delineation as areas with thick coarse-grained sediment. The source of water in wells varies from mostly bedrock wells in the lower complexity terranes to mostly Quaternary wells in the higher complexity terranes where the sediment generally is thickest.

Comparisons of similarities and dissimilarities among the hydrogeologic terranes are based on a tree diagram compiled from a hierarchical cluster analysis of a matrix composed of metrics based on lithologic data and the distribution of water wells in each terrane. This analysis indicates groups of terranes that can be treated as comparable when analyzing groundwater flow and quality, because of similarities within sediment and aquifer characteristics. Terranes 4A and 4B (Long Island, Cape Cod, and Nebraska), are thicker and coarser than other terranes, and appear on a separate branch of the tree, distant from the other terranes. Terranes $1 \mathrm{~A}, 1 \mathrm{~B}, 1 \mathrm{C}, 1 \mathrm{D}$, and $1 \mathrm{E}$ (the Northeast, areas south of the limit of Late Wisconsinan glaciation in the Midwest, the Driftless area, and areas adjacent to Lake Superior) are similar, and compose a separate branch. Several groups of terranes are also similar: terrranes $2 \mathrm{C}$ and 2D in Iowa and Minnesota; the higher complexity terranes 3A, $3 \mathrm{~B}$, and $3 \mathrm{C}$ in Michigan, Minnesota, and the Prarie Coteau; and terranes $1 \mathrm{~F}, 2 \mathrm{~A}, 2 \mathrm{~B}$, and $2 \mathrm{E}$ from Ohio through Illinois and into Wisconsin, the Dakotas, and Montana.

Aquifer-material intervals identified within the lithologic logs are assumed to correspond to Quaternary aquifers, an assumption that is most valid for logs from Quaternary water wells and unconfined aquifer-material intervals identified in logs from test borings. The assumption is less certain for confined aquifer-material intervals identified in logs from deep test borings that could be isolated lenses of coarse material. Aquifer-material intervals indicated on maps prepared from the lithologic logs do correlate well with aquifer systems delineated on maps in Illinois, Indiana, and North Dakota. Unconfined aquifer systems (such as the Kanakee and St. Joseph aquifer systems in Indiana and the Sheyenne aquifer in North Dakota) are depicted as unconfined on maps derived from lithologic logs. Confined aquifer systems (such as the Mahomet-Lafayette system in Illinois and Indiana and the Spiritwood and Page systems in North Dakota) are depicted as confined.

The large scale of the study limits resolution at which the maps can be interpreted; for example, alluvial units are not aligned along the thalwegs of some valleys in the Northeast and the Northwest, and some small valleys are not mapped at all. Data from lithologic logs are aggregated and mapped at the 1-km scale, so local variations in aquifer characteristics (for example, thickness and depth) are averaged over this area. Also, lithologic logs are biased toward shallow depths because not all logs penetrate the entire thickness of Quaternary sediment. Shallow depths are more commonly exploited for water supply, however, so this bias should not limit the utility of the 
sediment and aquifer descriptions, particularly in areas where the sediment is more than $100 \mathrm{~m}$ thick. Finally, the density and information content of lithologic logs varies among States, which could bias the mapping and statistics in some areas.

This hydrogeologic framework can be used to construct three-dimensional, groundwater flow models in ongoing studies of the USGS for the glaciated United States. Maps of texture and thickness of Quaternary sediments can be used to represent hydraulic conductivity and transmissivity, and the depth of aquifer-material intervals, and areas of confined and unconfined aquifers can be used to design model layering. The hydrogeologic terrane classification can be used as a surrogate in metamodels for variables that cannot be mapped, such as vertical hydraulic conductivity. Because the terrane classification reflects sediment texture and the degree of aquifer confinement, this hydrogeologic framework can also contribute to the explanation of variations in groundwater-quality across the glaciated United States.

\section{References Cited}

Arnold, T.L., Warner, K.L., Groschen, G.E., Caldwell, J.P., and Kalkhoff, S.J., 2008, Hydrochemical regions of the glacial aquifer system, northern United States, and their environmental and water-quality characteristics: U.S. Geological Survey Scientific Investigations Report 2008-5015, 83 p. with appendixes. [Also available at https://pubs.usgs.gov/ sir/2008/5015/.]

Atwater, B.F., 1986, Pleistocene glacial-lake deposits of the Sanpoil River Valley, northeastern Washington: U.S. Geological Survey Bulletin 1661, 39 p. [Also available at https://pubs.er.usgs.gov/publication/b1661.]

Bayless, E.R., Arihood, L.D., Reeves, H.W., Sperl, B.J., Qi, S.L., Stipe, V.E., and Bunch, A.R., 2017, Maps of hydrogeologic information created from standardized water-well drillers' records of the glaciated United States: U.S. Geological Survey Scientific Investigations Report 2015-5105, 34 p. [Also available at https://doi.org/10.3133/ sir20155105.]

Best, A., Arnaud, E., Parker, B., Aravena, R., and Dunfield, K., 2015, Effects of glacial sediment type and land use on nitrate patterns in groundwater: Groundwater Monitoring and Remediation, v. 35, no. 1, p. 68-81. [Also available at https://doi.org/10.1111/gwmr.12100.]

Booth, D.B., Troost, K.G., Clague, J.J., and Waitt, R.B., 2003, The cordilleran ice sheet, in Gillespie, A.R., Porter, S.C., and Atwater, B.F., eds., The Quaternary period in the United States: Developments in Quaternary Sciences, v. 1, special issue, p. 17-43. [Also available at https://doi.org/10.1016/ S1571-0866(03)01002-9.]
Dewald, T., McKay, L., Bondelid, T., Johnston, C., Moore, R., and Rea, A., 2012, NHDPlus version 2-User guide: U.S. Environmental Protection Agency, 181 p., accessed November 15, 2014, at http://www.horizon-systems.com/NHDPlus/ NHDPlusV2_documentation.php.

Dyke, A.S., 2004, An outline of North American deglaciation with emphasis on central and northern Canada, in Ehlers, J., and Gibbard, P.L., eds., Quaternary glaciationsExtent and chronology, part II-North America: Developments in Quaternary Science, v. 2, pt. B, special issue, p. 373-424. [Also available at https://doi.org/10.1016/ S1571-0866(04)80209-4.]

Eberts, S.M., and George, L.L., 2000, Regional groundwater flow and geochemistry in the Midwestern Basin and Arches aquifer system in parts of Indiana, Ohio, Michigan, and Illinois: U.S. Geological Survey Professional Paper 1423-C, 103 p. [Also available at https://pubs.er.usgs.gov/ publication/pp1423C.]

Ely, D.M., and Kahle, S.C., 2004, Conceptual model and numerical simulation of the groundwater-flow system in the unconsolidated deposits of the Colville River watershed, Stevens County, Washington: U.S. Geological Survey Scientific Investigations Report 2004-5237, 73 p. [Also available at https://pubs.usgs.gov/sir/2004/5237/.]

Feinstein, D.T., Hunt, R.J., and Reeves, H.W., 2010, Regional groundwater-flow model of the Lake Michigan basin in support of Great Lakes Basin water availability and use studies: U.S. Geological Survey Scientific Investigations Report 2010-5109, 379 p. [Also available at https://pubs.usgs.gov/ sir/2010/5109/.]

Flint, R.F., 1971, Glacial and Quaternary geology: New York, John Wiley and Sons, Inc., 892 p.

Focazio, M.J., Reilly, T.E., Rupert, M.G., and Helsel, D.R., 2002, Assessing ground-water vulnerability to contamination-Providing scientifically defensible information for decision makers: U.S. Geological Survey Circular 1224, 33 p. [Also available at https://pubs.usgs.gov/circ/2002/ circ1224/.]

Fullerton, D.S., Bush, C.A., and Pennell, J.N., 2003, Map of surficial deposits and materials in the eastern and central United States (east of $102^{\circ}$ west longitude): U.S. Geological Survey Geologic Investigations Series Map I-2789, scale 1:2,500,000. [Also available at https://pubs.usgs.gov/ imap/i-2789/.]

Fullerton, D.S., and Richmond, G.M., comps., [variously dated], Quaternary geologic atlas of the United States: U.S. Geological Survey Miscellaneous Investigations Series Map I-1420, 33 quadrangles, scale 1:1,000,000. [Also available at https://on.doi.gov/2vwOIXJ.]

Gillespie, A.R., Porter, S.C., and Atwater, B.F., eds., 2004, The Quaternary period in the Unites States: Developments in Quaternary Sciences, v. 1, special issue, 584 p. 
Gower, J.C., 1971, A general coefficient of similarity and some if its properties: Biometrics, v. 27, no. 4, p. 857-874. [Also available at https://doi.org/10.2307/2528823.]

Haj, A.E., Soller, D.R., Reddy, J.E., Kauffman, L.J., Yager, R.M., and Buchwald, C.A., 2018, Hydrogeologic framework for characterization and occurrence of confined and unconfined aquifers in quaternary sediments in the glaciated conterminous United States-A digital map compilation and database: U.S. Geological Survey Data Series 1090, 31 p., https://doi.org/10.3133/ds1090.

Handman, E.H., Haeni, F.P., and Thomas, M.P., 1986, Water resources inventory of Connecticut, part 9-Farmington River Basin: Connecticut Water Resources Bulletin no. 29, 92 p., 4 pls., scale 1:48,000. [Also available at https://pubs.er.usgs.gov/publication/70038342.]

Hansel, A.K., and McKay, E.D., III, 2010, Quaternary period, in Kolata, D.R., and Nimz, C.K., eds., Geology of Illinois: Urbana-Champaign, Ill., Illinois State Geological Survey, p. 216-247.

Herzog, B.L., Larson, D.R., Abert, C.C., Wilson, S.D., and Roadcap, G.S., 2003, Hydrostratigraphic modeling of a complex, glacial-drift aquifer system for importation into MODFLOW: Groundwater, v. 41, no. 4, p. 57-65. [Also available at https://doi.org/10.1111/j.1745-6584.2003. tb02568.x.]

Jones, M.A., 1999, Geologic framework of the Puget Sound aquifer system, Washington and British Columbia: U.S. Geological Survey Professional Paper 1424-C, 31 p., 18 pls. [Also available at https://pubs.er.usgs.gov/ publication/pp1424C.]

Kahle, S.C., Caldwell, R.R., and Bartolino, J.R., 2005, Compilation of geologic and hydrologic information for the Spokane Valley-Rathdrum Prairie aquifer, Bonner and Kootenai Counties, Idaho, and Spokane County, Washington: U.S. Geological Survey Scientific Investigations Report 2005-5227, 64 p. [Also available at https://pubs.usgs.gov/ sir/2005/5227/.]

Kehew, A.E., and Boettger, W.M., 1986, Depositional environments of buried-valley aquifers in North Dakota: Groundwater, v. 24, no. 6, p. 728-734. [Also available at https://doi.org/10.1111/j.1745-6584.1986.tb01688.x.]

Kontis, A.L., Randall, A.D., and Mazzaferro, D.L., 2004, Regional hydrology and simulation of flow of stratifieddrift aquifers in the glaciated northeastern United States: U.S. Geological Survey Professional Paper 1415-C, 156 p., 3 pls. [Also available at https://pubs.er.usgs.gov/publication/ pp1415C.]

Krulikas, R.K., and Koszalka, E.J., 1983, Geologic reconnaissance of an extensive clay unit in north-central Suffolk County, Long Island, New York: U.S. Geological Survey Water-Resources Investigations Report 82-4075, 13 p., 1 pl. [Also available at https:/pubs.er.usgs.gov/publication/ wri824075.]
Masterson, J.P., Pope, J.P., Fienen, M.N., Monti, J., Jr., Nardi, M.R., and Finkelstein, J.S., 2016, Documentation of a groundwater flow model developed to assess groundwater availability in the Northern Atlantic Coastal Plain aquifer system from Long Island, New York, to North Carolina: U.S. Geological Survey Scientific Investigations Report 2016-5076, 70 p. [Also available at https://doi.org/10.3133/ sir20165076.]

Masterson, J.P., Pope, J.P., Monti, J., Jr., Nardi, M.R., Finkelstein, J.S., and McCoy, K.J., 2013, Hydrogeology and hydrogeologic conditions of the Northern Atlantic Coastal Plain aquifer system from Long Island, New York, to North Carolina: U.S. Geological Survey Scientific Investigations Report 2013-5133, 76 p. [Also available at https://pubs.usgs.gov/sir/2013/5133/.]

Masterson, J.P., Stone, B.D., Walter, D.A., and Savoie, J.G., 1997, Hydrogeologic framework of western Cape Cod, Massachusetts, U.S. Geological Survey Hydrologic Atlas 741, 1 sheet, scale 1:50,000. [Also available at https://pubs.er.usgs.gov/publication/ha741.]

Maupin, M.A., and Barber, N.L., 2005, Estimated withdrawals from principal aquifers in the United States, 2000: U.S. Geological Survey Circular 1279, 52 p. [Also available at https://pubs.usgs.gov/circ/2005/1279/pdf/circ1279.]

Maupin, M.A., Kenny, J.F., Hutson, S.S., Lovelace, J.K., Barber, N.L., and Linsey, K.S., 2014, Estimated use of water in the United States in 2010: U.S. Geological Survey Circular 1405, 56 p. [Also available at https://doi.org/10.3133/ cir1405.]

Miller, D.A., and White, R.A., 1998, A conterminous United States multilayer soil characteristics dataset for regional climate and hydrology modeling: Earth Interactions, v. 2, no. 2, p. 1-26.

Miller, J.A., ed., 2000, The ground water atlas of the United States: U.S. Geological Survey Hydrologic Atlas 730, [various scales], [various sheets]. [Also available at https://pubs.er.usgs.gov/publication/ha730.]

Oldale, R.N., and Barlow, R.A., 1986, Geologic map of Cape Cod and the Islands, Massachusetts: U.S. Geological Survey Miscellaneous Investigations Series Map I-1763. [Also available at https://pubs.er.usgs.gov/publication/i1763.]

Randall, A.D., 2001, Hydrogeologic framework of stratifieddrift aquifers in the glaciated northeastern United States: U.S. Geological Survey Professional Paper 1415-B, 179 p., 1 pl. [Also available at https://pubs.er.usgs.gov/publication/ pp1415B.]

Roadcap, G.S., Knapp, H.V., Wehrmann, H.A., and Larson, D.R., 2011, Meeting east-central Illinois water needs to 2050-Potential impacts on the Mahomet Aquifer and surface reservoirs: Illinois State Water Survey Contract Report 2011-08, 188 p. [Also available at http://hdl.handle.net/2142/39869.] 
Roberts, H.M., Muhs, D.R., and Bettis, E.A., III, 2007, Loess records-North America, in Elias, S., ed., Encyclopedia of Quaternary sciences: Amsterdam, Elsevier, p. 14561466, accessed July 19, 2018, at https://doi.org/10.1016/ B0-44-452747-8/00163-0.

Rowe, G.L., Gilliom, R.J., and Woodside, M.D., 2013, Tracking and forecasting the Nation's water qualityPriorities and strategies for 2013-2023: U.S. Geological Survey Fact Sheet 2013-3008, 6 p. [Also available at https://pubs.er.usgs.gov/publication/fs20133008.]

Rutledge, A.T., 1998, Computer programs for describing the recession of ground-water discharge and for estimating mean ground-water recharge and discharge from streamflow records-Update: U.S. Geological Survey Water-Resources Investigations Report 98-4148, accessed February 10, 2017, at https://pubs.er.usgs.gov/publication/wri984148.

Schilling, K.E., 2009, Investigating local variation in groundwater recharge along a topographic gradient, Walnut Creek, Iowa, USA: Hydrogeology Journal, v. 17, no. 2, p. 397-407. [Also available at https://doi.org/10.1007/ s10040-008-0347-5.]

Sibrava, V., Bowen, D.Q., and Richmond, G.M., eds., 1986, Quaternary glaciations in the northern hemisphere: International Geological Correlation Programme Project 24 final report, $511 \mathrm{p}$.

Smolensky, D.A., Buxton, H.T., and Shernoff, P.K., 1989, Hydrologic framework of Long Island, New York: U.S. Geological Survey Hydrologic Investigations Atlas HA-709, 3 sheets, scale 1:250,000. [Also available at https://pubs.er.usgs.gov/publication/ha709.]

Soller, D.R., 1993, Map showing the thickness and character of Quaternary sediments in the glaciated United States east of the Rocky Mountains-Northeastern states, the Great Lakes, and parts of southern Ontario and the Atlantic offshore area (east of $80^{\circ} 31^{\prime}$ longitude): U.S. Geological Survey Miscellaneous Investigations Series Map I-1970-A, scale 1:1,000,000. [Also available at https://ngmdb.usgs.gov/Prodesc/proddesc_10047.htm.]

Soller, D.R., 1994, Map showing the thickness and character of Quaternary sediments in the glaciated United States east of the Rocky Mountains-Northeastern plains States (west of $102^{\circ}$ west longitude): U.S. Geological Survey Miscellaneous Investigations Series Map I-1970-D, scale 1:1,000,000. [Also available at https://ngmdb.usgs.gov/Prodesc/proddesc_10048.htm.]

Soller, D.R., 1997, Map showing the thickness and character of Quaternary sediments in the glaciated United States, east of the Rocky Mountains-Northern and central plains states $\left(90^{\circ}\right.$ to $102^{\circ}$ west longitude): U.S. Geological Survey Miscellaneous Investigations Series Map I-1970-C, scale 1:1,000,000. [Also available at https://ngmdb.usgs.gov/Prodesc/proddesc_13020.htm.]
Soller, D.R., 1998, Map showing the thickness and character of Quaternary sediments in the glaciated United States east of the Rocky Mountains-Northern Great Lakes States and central Mississippi Valley States, the Great Lakes, and southern Ontario $\left(80^{\circ} 31^{\prime}\right.$ to $93^{\circ}$ west longitude): U.S. Geological Survey Miscellaneous Investigations Series Map I-1970-B, scale 1:1,000,000. [Also available at https://ngmdb.usgs.gov/Prodesc/proddesc_13019.htm.]

Soller, D.R., 2001, Map showing the thickness and character of Quaternary sediments in the glaciated United States east of the Rocky Mountains: U.S. Geological Survey Miscellaneous Investigations Series Map I-1970-E, scale 1:3,500,000. [Also available at https:/pubs.er.usgs.gov/publication/i1970E.]

Soller, D.R., and Garrity, C.P., 2018, Quaternary sediment thickness and bedrock topography of the glaciated United States east of the Rocky Mountains: U.S. Geological Survey Scientific Investigations Map 3392, 2 sheets, scale 1:5,000,000, accessed July 1, 2018, at https://doi.org/10.3133/sim3392.

Soller, D.R., Packard, P.H., and Garrity, C.P., 2012, Database for USGS Map I-1970-Map showing the thickness and character of Quaternary sediments in the glaciated United States east of the Rocky Mountains: U.S. Geological Survey Data Series 656, scale 1:1,000,000. [Also available at https://pubs.usgs.gov/ds/656/.]

Soller, D.R., Reheis, M.C., Garrity, C.P., and Van Sistine, D.R., 2009, Map database for surficial materials in the conterminous United States: U.S. Geological Survey Data Series 425, scale 1:5,000,000, accessed June 2017 at http://pubs.usgs.gov/ds/425/.

Thornton, P.E., Thornton, M.M., Mayer, B.W., Wei, Y., Devarakonda, R., Vose, R.S., and Cook, R.B., 2017, Daymet - Daily surface weather data on a 1-km grid for North America, version 3: Oak Ridge National Laboratory Distributed Active Archive Center for Geochemical Dynamics data, accessed April 19, 2017, at https://doi.org/10.3334/ ORNLDAAC/1328.

Thornton, P.E., Thornton, M.M., Mayer, B.W., Wilhelmi, N., Wei, Y., Devarakonda R., and Cook, R.B., 2014, DaymetDaily surface weather data on a 1-km grid for North America, version 2: Oak Ridge National Laboratory Distributed Active Archive Center for Geochemical Dynamics data, accessed August 16, 2016, at https://doi.org/10.3334/ ORNLDAAC/1219.

U.S. Department of Agriculture, 2007, Hydrologic soil groups, chap. 7 of Hydrology: U.S. Department of Agriculture National Engineering Handbook, pt. 630, accessed August 2012 at http://directives.sc.egov.usda.gov/ OpenNonWebContent.aspx?content=17757.wba. 
U.S. Geological Survey [USGS], 2015, USGS water data for the Nation: U.S. Geological Survey National Water Information System database, accessed August 13, 2015, at https://doi.org/10.5066/F7P55KJN.

U.S. Geological Survey [USGS], [n.d.], Geologic maps of U.S. states: U.S. Geological Survey spatial data, accessed February 10, 2017, at https://mrdata.usgs.gov/geology/ state/.

Vaccaro, J.J., Hansen, A.J., and Jones, M.A., 1998, Hydrogeologic framework of the Puget Sound aquifer system, Washington and British Columbia: U.S. Geological Survey Professional Paper 1424-D, 77 p. [Also available at http://pubs.er.usgs.gov/publication/pp1424.]

Walter, D.A., and Whealan, A.T., 2005, Simulated water sources and effects of pumping on surface and ground water, Sagamore and Monomoy flow lenses, Cape Cod, Massachusetts: U.S. Geological Survey Scientific Investigations Report 2004-5181, 85 p. [Also available at https://pubs.er.usgs.gov/publication/sir20045181.]
Warner, K.L., and Ayotte, J.D., 2015, The quality of our Nation's waters-Water quality in the glacial aquifer system, northern United States, 1993-2009: U.S. Geological Survey Circular 1352, 128 p. [Also available at https://doi.org/10.3133/cir1352.]

Westenbroek, S.M., Kelson, V.A., Dripps, W.R., Hunt, R.J., and Bradbury, K.R., 2010, SWB-A modified Thornthwaite-Mather soil-water balance code for estimating groundwater recharge: U.S. Geological Survey Techniques and Methods, book 6, chap. A31, 60 p. [Also available at https://pubs.usgs.gov/tm/tm6-a31/.]

Yager, R.M., Haj, A.E., Soller, D.R., Kauffman, L.J., Reddy, J.E., Buchwald, C.A., and Westenbroek, S.M., 2018, Digital products and databases used to develop a hydrogeologic framework for Quaternary sediments within the glaciated conterminous United States and to characterize aquifers within them: U.S. Geological Survey data release, https://doi.org/10.5066/F7HH6J8X. 



\section{Appendix 1. Development and Application of the Soil-Water Balance Model to the Glaciated Conterminous United States}

The magnitude and distribution of groundwater recharge in the glaciated conterminous United States was computed using national spatial data sets and the soil-water balance (SWB) model (Westenbroek and others, 2010). This appendix documents the application of the SWB model, and lists the assumptions and input data required in the model application. Separate SWB models were run for each of the 644, eightdigit hydrologic-unit-code watersheds (medium-sized river basins, about 2,200 nationwide) that comprise the glaciated conterminous United States. Model results were then aggregated to construct a recharge map for the entire area. A model archive containing the inputs and outputs for all 644 SWB model runs is published in Yager and others (2018).

Prior estimates of recharge have been made during the past 15 years that include areas within the glaciated conterminous United States (Wolock, 2003; Neff and others, 2006). Two estimates that cover all or most of the glaciated conterminous United States have been made in the past 2 years (Reitz and others, 2017; Trost and others, 2018). Healy and Scanlon (2010) suggest that applying multiple recharge-estimation methods is the best approach to bracket possible values in a particular region and to evaluate the magnitude of uncertainties associated with recharge estimates. For this reason, this appendix includes comparisons of recharge computed by the SWB model in this study with recharge computed by Trost and others (2018) and Reitz and others (2017).

The study documented in this report and in Trost and others (2018) used SWB, a deterministic model that uses gridded data and physically based parameters to apportion water derived from daily rainfall and snowmelt into surface runoff, evapotranspiration, recharge, and water storage in the soil column. The nationwide recharge estimates of Reitz and others (2017) used a water-balance approach, and estimated recharge as the remainder of mean annual precipitation (Parameter-elevation Relationships on Independent Slopes Model [PRISM] interpolation method; Daly and others, 2008) minus evapotranspiration (Reitz and others, 2017) and surface runoff. Surface runoff was estimated from a regression analysis that was based on several factors, including net precipitation, soil type, and surficial geology.

Recharge estimates from each of these three studies are compared with estimates of base flow computed from hydrograph-separation techniques applied to watersheds ranging in area from 100 to 1,000 square kilometers. Although the recharge estimates generally compare favorably with estimates of base flow, each recharge estimate displays a differing spatial pattern. The differences generated by the three methods highlight the problem of model nonuniqueness associated with estimating recharge.

\section{Soil-Water Balance Model Development}

The SWB model in this study was constructed using national spatial data sets to calculate spatial and temporal variations in recharge based on climatological data and on soil and landscape properties. Computation of water-budget components (surface runoff, evapotranspiration, recharge, and soil storage) relies on relations between the surface runoff, land cover, and hydrologic soil group (Cronshey and others, 1986) and the estimated values of evapotranspiration and temperature (Hargreaves and Samani, 1985). Water storage in the soil column is estimated using a modified Thornwaite-Mather accounting method on a daily basis (Westenbroek and others, 2010). The SWB model in this study represents a 14-year period of record from 2000 through 2013.

Landscape data were obtained from the National Land Cover Database (NLCD; table 1.1; Homer and others, 2015). Cultivated crops cover more than one-third of the glaciated United States (table 1.2), whereas deciduous forest, pasture, and hay or grassland cover a nearly equal area. Runoff from and infiltration through the land cover were computed using a combination of soils and surficial geologic mapping, and parameter values specified by Trost and others (2018). Four hydrologic soil groupings, ranging from low to high runoff potential, were obtained from a modified version the State Soil Geographic Database (STATSGO; Miller and White, 1998).

The SWB model prepared for this study was constructed at a higher grid resolution (250 meters [m]) than that of the two other recent recharge-estimation methods $(1,000 \mathrm{~m})$. In addition, the SWB model of Trost and others (2018) did not include Idaho, Washington, or parts of Montana and Wiscon$\sin$. The available water capacity and maximum recharge rate, key components in the water-budget calculation in the SWB model, were based solely on hydrologic soil groups by Trost and others (2018), whereas, in this study, the available water capacity and maximum recharge values also incorporated the mapping of surficial Quaternary sediments, as described below. Other parameters specified in the SWB model for this study were the same as, or were based on, the SWB model of Trost and others (2018), which was calibrated using the parameter-estimation program PEST (Doherty, 2010).

Recharge in the SWB model is computed as surplus water in excess of the soil field capacity, a product of available water capacity and root depth in the soil column. Surplus water in excess of the specified daily maximum recharge rate is classified as "rejected recharge" and is passed to downslope cells through a flow-routing algorithm using the "D8" parameter (table 1.2). D8 flow-direction grids were derived from data generated by the HydroSHEDS Project, which has developed 
Table 1.1. Spatial data assigned to parameters in the soil-water balance model for the glaciated conterminous United States.

[NLCD, National Land Cover Database; STATSGO, State Soil Geographic Database; m, meter; -- not applicable, vector data; $\sim$, about]

\begin{tabular}{llll}
\hline \multicolumn{1}{c}{ Type } & \multicolumn{1}{c}{ Data source } & Resolution & Soil-water balance parameters \\
\hline Land cover & NLCD $2011^{1}$ & $30 \mathrm{~m}$ & Land Cover. \\
Soils & STATSGO $^{2}$ & - & Runoff Curve Numbers. \\
& & Root Depth. & Maximum Recharge Rate. \\
& & 3 arc-seconds $(\sim 100 \mathrm{~m})$ & D8 flow direction. \\
Flow direction & HydroSHEDS & Available Water Capacity. \\
Available water capacity & GESS $^{4}$ & & \\
\hline${ }^{1}$ Homer and others (2015). & &
\end{tabular}

a consistent flow-direction coverage worldwide at an approximate 90-m resolution (Lehner and others, 2008). Root depths were assigned for each land-use type based on values obtained from the SWB model of Trost and others (2018).

Available water capacities and maximum recharge rates were initially assigned to GESS map units (fig. 5) on the basis of the texture and depositional environment of the surficial materials (table 1.3) using the four texture classes defined in Haj and others (2018, table 3). The specified values were based on ranking the recharge potential of different types of sediment based on texture, using ranges of values obtained by a previous application of the SWB model to the Lake Michigan watershed (Westenbroek and others, 2010). The rationale behind this decision was to ensure higher recharge in lowlands occupied by coarse-grained, stratified Quaternary sediment (for example, alluvium and outwash) than in adjacent uplands underlain by fine-grained till. In many parts of the glaciated United States similar hydrologic soil groupings overlie lowland and adjacent upland areas, so basing available water capacity solely on hydrologic soil groups in the SWB model would produce similar recharge values for both areas. This is contrary to research that indicates recharge through valley alluvium or outwash is about three times the recharge through till in New England (Handman and others, 1986) and Iowa (Schilling, 2009).

The specified values for available water capacity and maximum recharge rates that were based on the texture of surficial materials were then averaged with corresponding values obtained by hydrologic soil group from the STATSGO data base (Miller and White, 1998) to obtain the final values input to the SWB model. In this way, information from mapping of surficial units and hydrologic soil groups were incorporated in the parameter values. The available water capacities were computed using the mean available-water capacity of the top $1 \mathrm{~m}$ of the soil profile from the STATSGO data base. The maximum recharge rates were computed using three saturated-permeability values reported at different depths in the soil profile (5-10, 20-30, and 40-60 centimeters) from the STATSGO data base. A factor of 0.015 was applied to the saturated-permeability values to correct for unit conversion and to adjust the range of resulting values to a range consistent with the specification of maximum recharge rates in the SWB model. The final values of available water capacity and maximum recharge rate input to the SWB model are shown in figure 1.1.

Figure 1.1. Parameters assigned in the soil-water balance model (this study) in the glaciated conterminous United States. $A$, Available water capacity and $B$, maximum recharge rate. Maps are available for download at https://doi.org/10.3133/sir20185091.

The SWB model runs were made using multiple computers to simulate recharge at more than 120 million, 250-meter grid cells grouped into 644, 8-digit hydrologic-unit-code watersheds across the glaciated United States. An HTCondor cluster (Litzkow and others, 1988; Thain and others, 2004) distributed the runs over 32 processors. Open-source, command-line tools from the GDAL Python project (Warmerdam, 2016) created subsets of the nationwide datasets used as model input, and then aggregated model results to create a complete recharge map of the glaciated United States. 
Table 1.2. Distribution of land cover in the glaciated conterminous United States in 2001.

[km², square kilometer]

\begin{tabular}{|c|c|c|c|c|}
\hline $\begin{array}{l}\text { Land } \\
\text { use } \\
\text { code }\end{array}$ & Description & Definition & $\begin{array}{c}\text { Area, } \\
\text { km }^{2}\end{array}$ & $\begin{array}{l}\text { Percent } \\
\text { of total } \\
\text { area }\end{array}$ \\
\hline 82 & Cultivated crops & $\begin{array}{l}\text { Areas used for the production of annual crops, such as corn, soybeans, veg- } \\
\text { etables, tobacco, and cotton, and also perennial woody crops such as or- } \\
\text { chards and vineyards. Crop vegetation accounts for greater than } 20 \text { percent } \\
\text { of total vegetation. This class also includes all land being actively tilled. }\end{array}$ & 648,244 & 34.6 \\
\hline 41 & Deciduous forest & $\begin{array}{l}\text { Trees generally greater than } 5 \text { meters tall, and greater than } 20 \text { percent of total } \\
\text { vegetation cover. More than } 75 \text { percent of the tree species shed foliage } \\
\text { simultaneously in response to seasonal change. }\end{array}$ & 299,973 & 16.0 \\
\hline 81 & Pasture/hay & $\begin{array}{l}\text { Grasses, legumes, or grass-legume mixtures planted for livestock grazing or } \\
\text { the production of seed or hay crops, typically on a perennial cycle. Pasture/ } \\
\text { hay vegetation accounts for greater than } 20 \text { percent of total vegetation. }\end{array}$ & 174,850 & 9.3 \\
\hline 71 & Grassland/herbaceous & $\begin{array}{l}\text { Gramanoid or herbaceous vegetation, generally greater than } 80 \text { percent of } \\
\text { total vegetation. These areas are not subject to intensive management such } \\
\text { as tilling, but can be utilized for grazing. }\end{array}$ & 162,810 & 8.7 \\
\hline 42 & Evergreen forest & $\begin{array}{l}\text { Trees generally greater than } 5 \text { meters tall, and greater than } 20 \text { percent of total } \\
\text { vegetation cover. More than } 75 \text { percent of the tree species maintain their } \\
\text { leaves all year. Canopy is never without green foliage. }\end{array}$ & 112,882 & 6.0 \\
\hline 90 & Woody wetlands & $\begin{array}{l}\text { Areas where forest or shrubland vegetation accounts for greater than } 20 \text { per- } \\
\text { cent of vegetative cover and the soil or substrate is periodically saturated } \\
\text { with or covered with water. }\end{array}$ & 104,118 & 5.6 \\
\hline 21 & Developed, open space & $\begin{array}{l}\text { Mixture of some constructed materials, but mostly vegetation in the form of } \\
\text { lawn grasses. Impervious surfaces account for less than } 20 \text { percent of total } \\
\text { cover. These areas most commonly include large-lot single-family housing } \\
\text { units, parks, golf courses, and vegetation planted in developed settings for } \\
\text { recreation, erosion control, or aesthetic purposes. }\end{array}$ & 82,761 & 4.4 \\
\hline 43 & Mixed forest & $\begin{array}{l}\text { Trees generally greater than } 5 \text { meters tall, and greater than } 20 \text { percent of total } \\
\text { vegetation cover. Neither deciduous nor evergreen species are greater than } \\
75 \text { percent of total tree cover. }\end{array}$ & 70,785 & 3.8 \\
\hline 11 & Open water & Open water, generally with less than 25 percent cover of vegetation or soil. & 58,333 & 3.1 \\
\hline 52 & Shrub and scrub & $\begin{array}{l}\text { Shrubs less than } 5 \text { meters tall with shrub canopy typically greater than } 20 \text { per- } \\
\text { cent of total vegetation. This class includes true shrubs, young trees in an } \\
\text { early successional stage or trees stunted from environmental conditions. }\end{array}$ & 49,142 & 2.6 \\
\hline 22 & Developed, low intensity & $\begin{array}{l}\text { Mixture of constructed materials and vegetation. Impervious surfaces account } \\
\text { for } 20 \text { to } 49 \text { percent of total cover. These areas most commonly include } \\
\text { single-family housing units. }\end{array}$ & 41,500 & 2.2 \\
\hline 95 & Emergent herbaceous wetlands & $\begin{array}{l}\text { Areas where perennial herbaceous vegetation accounts for greater than } \\
80 \text { percent of vegetative cover and the soil or substrate is periodically } \\
\text { saturated with or covered with water. }\end{array}$ & 36,770 & 2.0 \\
\hline 23 & Developed, medium intensity & $\begin{array}{l}\text { Mixture of constructed materials and vegetation. Impervious surfaces account } \\
\text { for } 50 \text { to } 79 \text { percent of the total cover. These areas most commonly include } \\
\text { single-family housing units. }\end{array}$ & 17,632 & 0.9 \\
\hline 24 & Developed, high intensity & $\begin{array}{l}\text { Highly developed areas where people reside or work in high numbers. Exam- } \\
\text { ples include apartment complexes, row houses, commercial and industrial. } \\
\text { Impervious surfaces account for } 80 \text { to } 100 \text { percent of the total cover. }\end{array}$ & 6,356 & 0.3 \\
\hline 31 & Barren land & $\begin{array}{l}\text { Bedrock, desert pavement, scarps, talus, slides, volcanic material, glacial } \\
\text { debris, sand dunes, strip mines, gravel pits, and other accumulations of } \\
\text { earthen material. Generally, vegetation accounts for less than } 15 \text { percent of } \\
\text { total cover. }\end{array}$ & 5,499 & 0.3 \\
\hline
\end{tabular}


Table 1.3. Available water capacities and maximum recharge rates assigned to texture classes of Quaternary sediment in the glaciated conterminous United States.

[--, not applicable; $\mathrm{mm} / \mathrm{d}$, millimeter per day $]$

\begin{tabular}{|c|c|c|}
\hline \multirow{2}{*}{$\begin{array}{l}\text { Available water capacity, } \\
\text { in percent }\end{array}$} & \multicolumn{2}{|c|}{ Quaternary sediment } \\
\hline & Stratified $^{1}$ & Unstratified \\
\hline 0.1 & Sandy $^{2}$ & -- \\
\hline 0.2 & Silty & Sandy ${ }^{3}$. \\
\hline 0.25 & -- & Silty $^{4}$. \\
\hline 0.3 & Clayey & Clayey. \\
\hline \multicolumn{3}{|l|}{$\begin{array}{l}\text { Maximum recharge rate, } \\
\text { in } \mathrm{mm} / \mathrm{d}\end{array}$} \\
\hline 50 & Sandy $^{2}$ & -- \\
\hline 25 & -- & -- \\
\hline 12.5 & Silty & Sandy ${ }^{3}$. \\
\hline 5 & -- & Silty ${ }^{4}$. \\
\hline 2.5 & Clayey & Clayey. \\
\hline
\end{tabular}

${ }^{1}$ Includes ice-contact sediments.

${ }^{2}$ Includes silty-sandy alluvial sediments.

${ }^{3}$ Includes bedrock and variable sediments.

${ }^{4}$ Includes peat.

\section{Comparison of Recharge Estimates}

Recharge estimates from all three studies are compared with base flow obtained from hydrograph separation applied to stream flow measured in gaged watersheds within the glaciated United States. The selected watersheds were selected from the Gages II database (Falcone, 2011) with the following criteria: the watershed size ranged from 100 to 1,000 square kilometers, no diversions or regulations were noted, and at least 10 years of record from 1950 to 2013 was available (Reitz and others, 2017). Mean annual values for runoff and base flow were estimated by applying the program PART (Rutledge, 1998) to each time series of stream-flow data for the 435 selected gages (Reitz and others, 2017).

Recharge estimates of Reitz and others (2017) are based on precipitation data from 2000 through 2013, whereas recharge estimates of Trost and others (2018) are taken from the application of a SWB model for 2000 through 2010. Their model application was calibrated to base flow obtained by applying the hydrograph-separation program HYSEP (Sloto and Crouse, 1996) to selected watersheds selected from the Gages II database (Falcone, 2011) using similar criteria to that of Reitz and others (2017). A summary of three methodologies used to estimate recharge is presented in table 1.4.

Residuals, computed as recharge estimates minus base flow obtained from PART, are similar for all three estimates with median values near zero (fig. 1.2). The interquartile range (25th to 75 th quartile) is slightly larger for the residuals from this study, as is the scatter and correlation in a direct comparison of recharge and base flow (fig. 1.3). This is expected because the recharge estimates for this study are from an uncalibrated SWB model, whereas estimates from the other two studies were from calibrated models. The overall comparison with base flow values is similar to results from the other two studies, however. Slightly fewer watersheds are available for comparison with the recharge estimates of Trost and others (2018), which do not extend into the Northwest.

A direct comparison of recharge maps for the glaciated United States reveals differences among the three results and indicates areas of spatial bias (fig. 1.4). Although the overall distributions of recharge are similar from the Northeast, through the Midwest and into the Northwest, the recharge map for this study is biased high in the southern Midwest (Ohio through Missouri) and is biased low in the upper Midwest (near Lakes Superior and Michigan). The recharge map of Trost and others (2018) displays a similar, though more muted pattern. In contrast, the recharge map of Reitz and others (2017) displays the least spatial bias overall. This comparison suggests that the structure of the SWB models could be responsible for bias in the results. As expected, the recharge

Table 1.4. Methodologies used to estimate recharge in the glaciated conterminous United States.

[m, meter; km, kilometer]

\begin{tabular}{lccccc}
\hline \multicolumn{1}{c}{ Study } & Climate data & $\begin{array}{c}\text { Grid } \\
\text { resolution }\end{array}$ & $\begin{array}{c}\text { Climate } \\
\text { data } \\
\text { resolution }\end{array}$ & Time period & Calibration \\
\hline This study & $\begin{array}{c}\text { DayMet (Thornton } \\
\text { and others, 2016) }\end{array}$ & $250 \mathrm{~m}$ & $1 \mathrm{~km}$ & $2000-2010$ & Uncalibrated. \\
Trost and others (2018) & $\begin{array}{c}\text { DayMet (Thornton } \\
\text { and others, 2014) }\end{array}$ & $1 \mathrm{~km}$ & $1 \mathrm{~km}$ & $1980-2013$ & $\begin{array}{c}\text { Base flow from HYSEP application to selected } \\
\text { Gages II watersheds, glaciated United States. }\end{array}$ \\
Reitz and others (2017) & $\begin{array}{c}\text { PRISM (Daly and } \\
\text { others, 2008) }\end{array}$ & $1 \mathrm{~km}$ & $4 \mathrm{~km}$ & $2000-2013$ & $\begin{array}{c}\text { Runoff from PART application to selected Gages II } \\
\text { watersheds, nationwide. }\end{array}$ \\
\hline
\end{tabular}




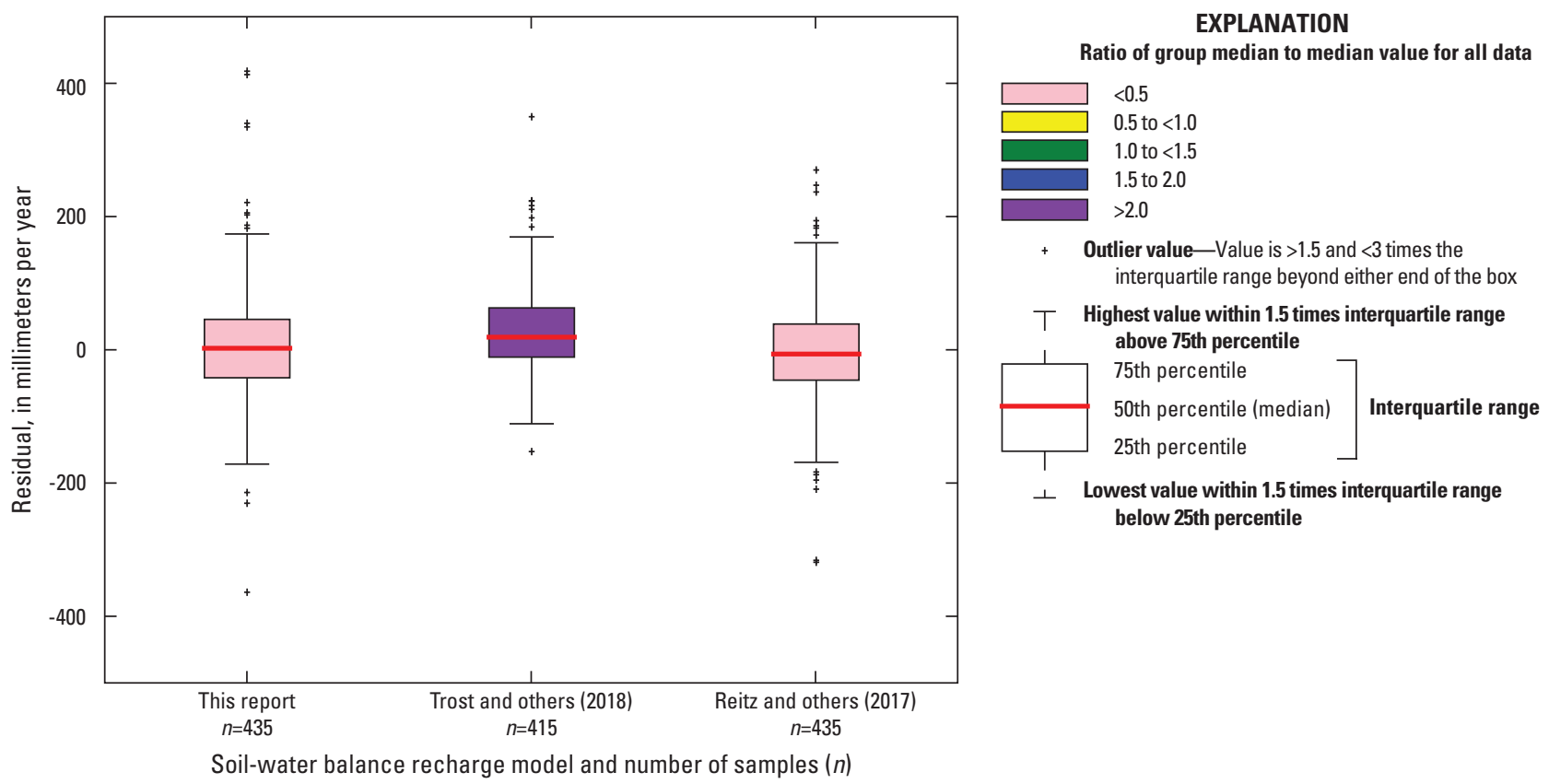

Figure 1.2. Distribution of residuals between base flow in the glaciated conterminous United States computed by PART and recharge computed by the soil-water balance model in this study, in in Trost and others (2018), and in Reitz and others (2017).

map for this study reflects high recharge rates in areas overlain by coarse-grained surficial materials, especially in the Midwest from Ohio through Iowa and into the Dakotas. The effect of surficial geology is less apparent in the other two recharge maps, which were not explicitly based on surficial geology.

Subtracting each of the other recharge maps from the recharge map obtained with this study highlights differences among the methods (fig. 1.5). The recharge map in this study predicts higher recharge rates (by more than 50 millimeters per year) in the southern Midwest and New England than the recharge map of Trost and others (2018). Lower recharge (by less than 50 millimeters per year) is predicted for the upper peninsula of Michigan, southern New England, and New York than in the recharge map of Trost and others (2018). Higher recharge is predicted for the southern Midwest, and lower recharge is predicted for most of the central and upper Midwest than in the recharge map of Reitz and others (2017). The recharge map in this study shows higher recharge in lowland areas and lower recharge in upland areas of the northwestern and northeastern United States than in the recharge map of Reitz and others (2017).

A comparison of recharge rates in each of the 17 hydrogeologic terranes displays a similar pattern overall, with differences in the interquartile ranges for some terranes (fig. 1.6). All three recharge maps indicate the highest recharge rates in the same terranes (1A, 1G, 3A, and $4 \mathrm{~A})$, as well as the lowest recharge rates in the same terranes $(1 \mathrm{C}, 1 \mathrm{~F}, 2 \mathrm{E}$, and $4 \mathrm{~B})$. The number of outliers above the 75th quartile is largest for the recharge map from this study, in which flow routing within the SWB model created areas of concentrated recharge. The number of outliers below the 25th percentile is largest for the recharge map of Reitz and others (2017), possibly because their methodology accounts for less recharge in areas of impervious surfaces and open water.

In summary, all three recharge maps compare favorably with estimated base flow at more than 400 gaged watersheds in the glaciated United States. The distribution of recharge estimated by this study reflects the surficial geology more realistically by predicting more recharge in lowland areas with coarse-grained sediments and less recharge in upland areas with fine-grained sediments. The comparison with estimated base flows indicates more spatial bias in the recharge map from this study, however. Assuming all three recharge maps are equally valid, the uncertainty in estimated recharge among the various terranes is depicted in figure 1.7, which summarizes differences in recharge computed for each grid cell by the three studies. Interquartile differences greater than 100 millimeters in comparisons among all three studies are recorded for hydrogeologic terranes $1 \mathrm{~A}$ and $4 \mathrm{~A}$ in the eastern glaciated United States. Interquartile differences greater than 100 millimeters are also apparent between this study and the other two studies in terranes $1 \mathrm{~B}, 1 \mathrm{C}, 2 \mathrm{~A}$, and $1 \mathrm{G}$. 

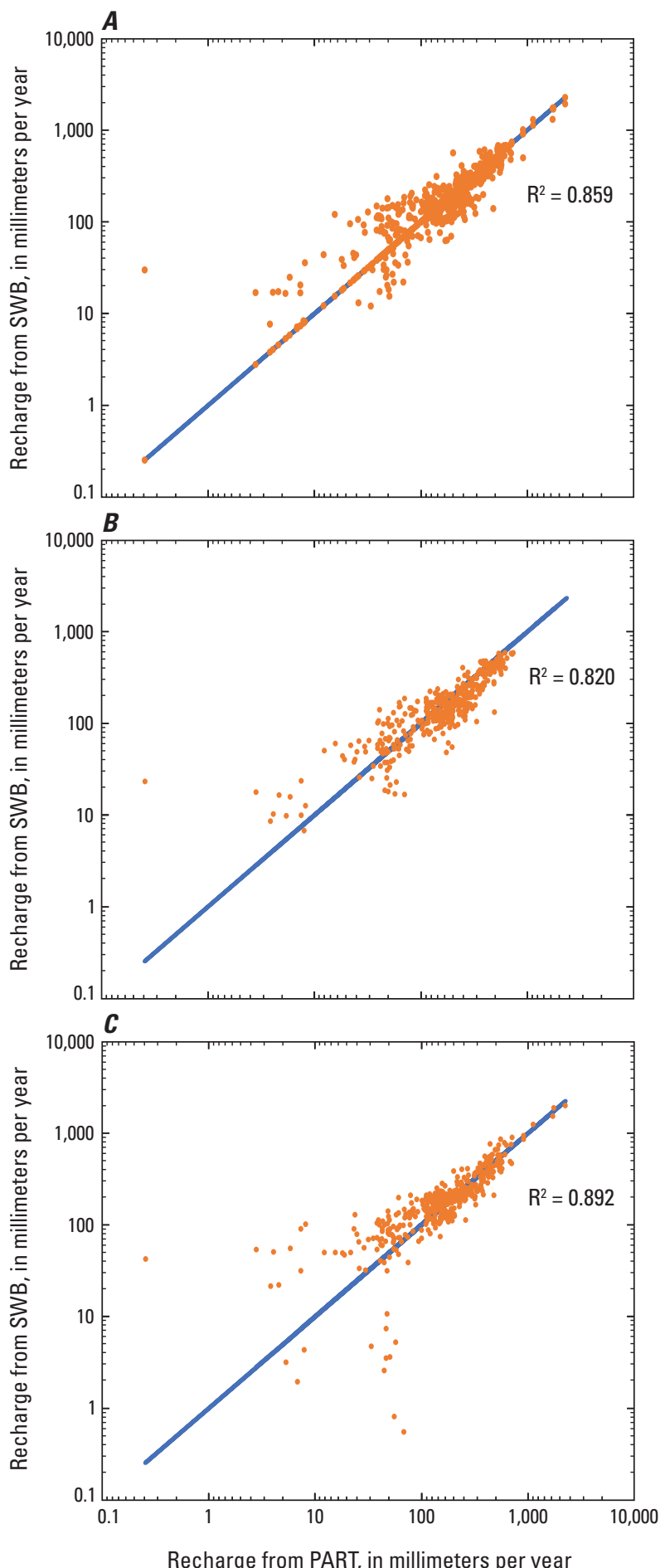

Figure 1.3. Residuals between base flow in the glaciated conterminous United States computed by PART and recharge computed by the soil-water balance model $A$, in this study, $B$, in Trost and others (2018), and $C$, in Reitz and others (2017).
Figure 1.4. Recharge and spatial distribution of residuals between base flow in the glaciated conterminous United States computed by PART and recharge computed by the soil-water balance model $A$, in this study, $B$, in Trost and others (2018), and $C$, in Reitz and others (2017). Maps are available for download at https://doi.org/10.3133/sir20185091.

Figure 1.5. Differences in recharge in the glaciated conterminous United States computed by the soil-water balance model in this study minus the soil-water balance model $A$, in Trost and others (2018) and $B$, Reitz and others (2017). Maps are available for download at https://doi.org/10.3133/sir20185091. 

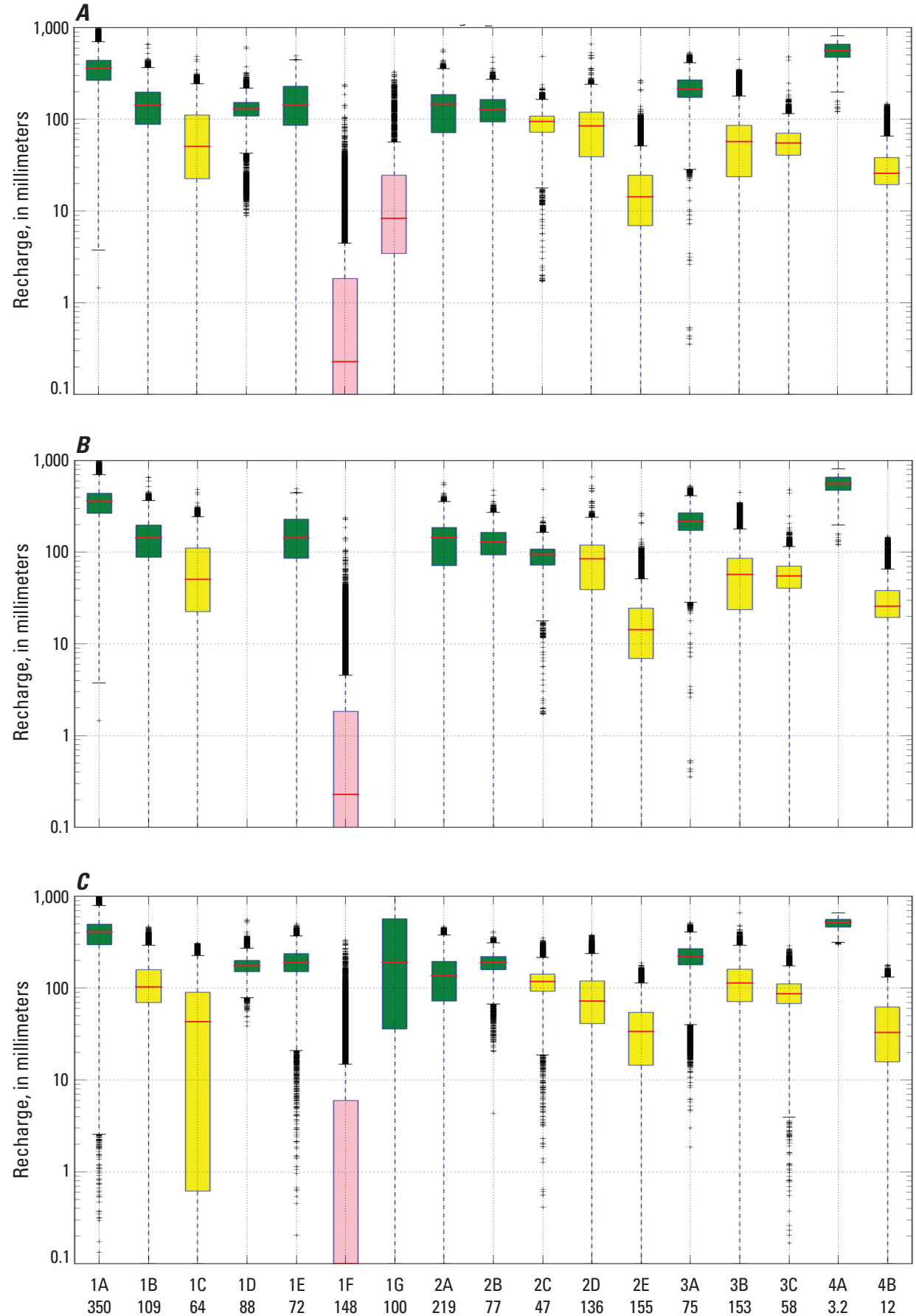

Hydrogeologic terrane and area, in 1,000 square kilometers
EXPLANATION

Ratio of group median to median value for all data-For plots with logarithmic axis, group median is based on log(median)

$<0.5$

$\square \quad 0.5$ to $<1.0$

$\square \quad 1.0$ to $<1.5$

$\square \quad 1.5$ to 2.0

$\square>2.0$

$+\quad$ Outlier value-Value is $>1.5$ and $<3$ times the interquartile range beyond either end of the box

$\top$ Highest value within 1.5 times interquartile range above 75 th percentile

$\square$ 75th percentile

50th percentile (median) Interquartile range 25th percentile

$\perp \quad$ Lowest value within 1.5 times interquartile range below 25th percentile

Figure 1.6. Recharge grouped by hydrogeologic terrane in the glaciated conterminous United States computed by the soil-water balance model $A$, in this study, $B$, in Trost and others (2018), and $C$, in Reitz and others (2017). 

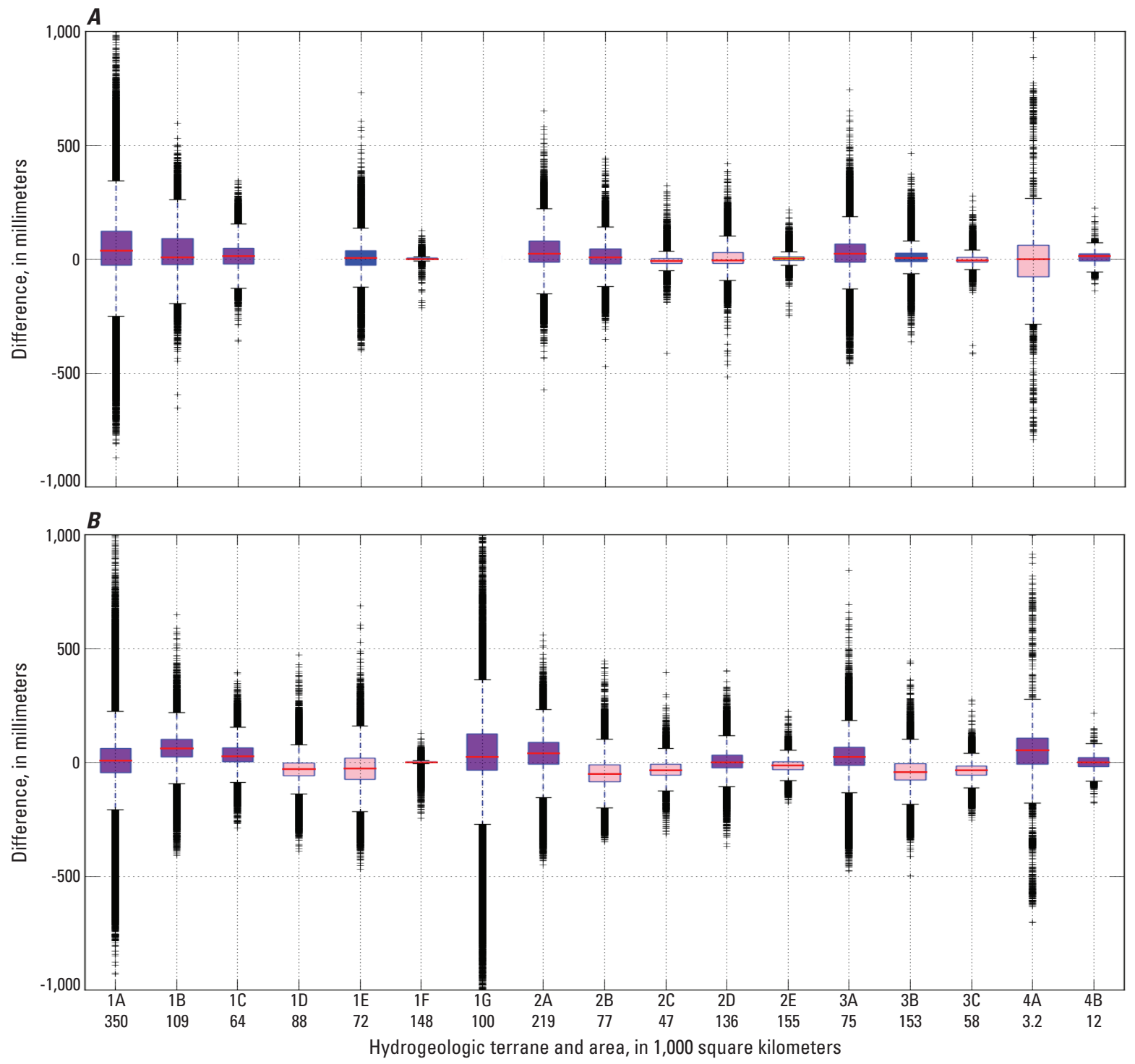

EXPLANATION

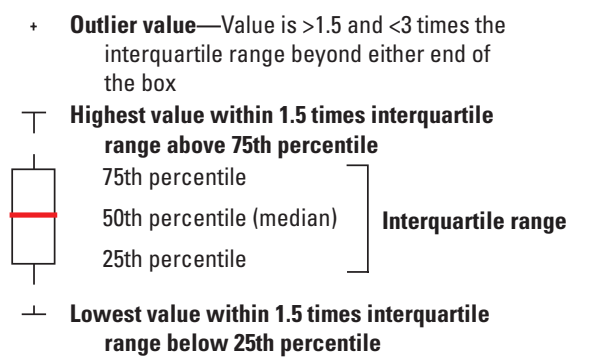

Ratio of group median to median value for all data

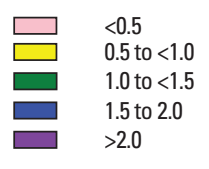

Figure 1.7. Difference in recharge grouped by hydrogeologic terrane in the glaciated conterminous United States. The soil-water balance model in this study minus the soil-water balance model $A$, in Trost and others (2018), and $B$, in Reitz and others (2017). 


\section{References Cited}

Cronshey, R., McCuen, R.H., Miller, N., Rawls, W., Robbins, S., and Woodward, D., 1999, Urban hydrology for small watersheds-TR-55 (2d ed.): Washington, D.C., U.S. Department of Agriculture Technical Release 55, 164 p. [Also available at https://www.nrcs.usda.gov/ Internet/FSE_DOCUMENTS/stelprdb1044171.pdf.]

Daly, C., Halbleib, M., Smith, J.I., Gibson, W.P., Doggett, M.K., Taylor, G.H., Curtis, J., and Pasteris, P.A, 2008, Physiographically sensitive mapping of temperature and precipitation across the conterminous United States: International Journal of Climatology, v. 28, no. 15, p. 2031-2064. [Also available at https://doi.org/10.1002/joc.1688.]

Doherty, J., 2010, PEST-Model-independent parameter estimation user manual: Brisbane, Australia, Watermark Numerical Computing, 336 p.

Falcone, J.A., 2011, GAGES-II-Geospatial attributes of gages for evaluating streamflow: U.S. Geological Survey data, accessed February 28, 2017, at https://pubs.er.usgs.gov/publication/70046617.

Haj, A.E., Soller, D.R., Reddy, J.E., Kauffman, L.J., Yager, R.M., and Buchwald, C.A., 2018, Hydrogeologic framework for characterization and occurrence of confined and unconfined aquifers in quaternary sediments in the glaciated conterminous United States-A digital map compilation and database: U.S. Geological Survey Data Series 1090, 31 p., https://doi.org/10.3133/ds1090.

Handman, E.H., Haeni, F.P., and Thomas, M.P., 1986, Water resources inventory of Connecticut, part 9-Farmington River Basin: Connecticut Water Resources Bulletin no. 29, 92 p., 4 pls., scale 1:48,000. [Also available at https://pubs.er.usgs.gov/publication/70038342.]

Hargreaves, G.H., and Samani, Z.A., 1985, Reference crop evapotranspiration from temperature: Applied Engineering in Agriculture, v. 1, no. 2, p. 96-99.

Healy, R.W., and Scanlon, B.R., 2010, Estimating groundwater recharge: Cambridge, Mass., Cambridge University Press, 238 p.

Homer, C.G., Dewitz, J.A., Yang, L., Jin, S., Danielson, P., Xian, G., Coulston, J., Herold, N.D., Wickham, J.D., and Megown, K., 2015, Completion of the 2011 National Land Cover Database for the conterminous United StatesRepresenting a decade of land cover change information: Photogrammetric Engineering and Remote Sensing, v. 81, no. 5 , p. $345-354$.
Johnson, T.D., and Belitz, K., 2017, Domestic well locations and populations served in the conterminous U.S.-1990: Science of The Total Environment, v. 607-608, p. 658-668. [Also available at https://doi.org/10.1016/j.scitotenv.2017.07.018.]

Lehner, B., Verdin, K., and Jarvis, A., 2008, New global hydrography derived from spaceborne elevation data: Eos, v. 89, no. 10, p. 93-94. [Also available at https://doi.org/10.1029/2008EO100001.]

Litzkow, M.J., Livny, M., and Mutka, M.W., 1988, CondorA hunter of idle workstations-Proceedings of the Eighth International Conference on Distributed Computing Systems, Jan Jose, Calif., June 13-17, 1988: The Institute of Electrical and Electronics Engineers, p. 104-111.

Miller, D.A., and White, R.A., 1998, A conterminous United States multilayer soil characteristics dataset for regional climate and hydrology modeling: Earth Interactions, v. 2, no. 2, p. 1-26.

Neff, B.P., Piggott, A.R., and Sheets, R.A., 2006, Estimation of shallow ground-water recharge in the Great Lakes Basin: U.S. Geological Survey Scientific Investigations Report 2005-5284, 31 p. [Also available at https://pubs.er.usgs.gov/ publication/sir20055284.]

Reitz, M., Sanford, W.E., Senay, G.B., and Cazenas, J., 2017, Annual estimates of evapotranspiration, recharge and quickflow runoff for the contiguous U.S. using empirical regression equations: Journal of the American Water Resources Association, v. 53, no. 4, p. 961-983. [Also available at https://doi.org/10.1111/1752-1688.12546.]

Rutledge, A.T., 1998, Computer programs for describing the recession of ground-water discharge and for estimating mean ground-water recharge and discharge from streamflow records-Update: U.S. Geological Survey Water-Resources Investigations Report 98-4148, accessed February 10, 2017 , at https://pubs.er.usgs.gov/publication/wri984148.

Schilling, K.E., 2009, Investigating local variation in groundwater recharge along a topographic gradient, Walnut Creek, Iowa, USA: Hydrogeology Journal, v. 17, no. 2, p. 397-407. [Also available at https://doi.org/10.1007/ s10040-008-0347-5.]

Sloto, R.A., and Crouse, M.Y., 1996, HYSEP-A computer program for streamflow hydrograph separation and analysis: U.S. Geological Survey Water-Resources Investigations Report 96-4040, 46 p. [Also available at http://pubs.er.usgs.gov/publication/wri964040.]

Thain, D., Tannenbaum, T., and Livny, M., 2005, Distributed computing in practice-The Condor experience: Concurrency and computation: Practice and Experience, v. 17, nos. 2-4, special issue, p. 323-356. [Also available at https://doi.org/10.1002/cpe.938.] 
Trost, J.J., Roth, J.L., Westenbroek, S.M., and Reeves, H.W., 2018, Simulation of potential groundwater recharge for the glacial aquifer system east of the Rocky Mountains, 1980-2011, using the soil-water balance model: U.S. Geological Survey Scientific Investigations Report 2018-5080, 51 p., https://doi.org/10.3133/sir20185080.

Warmerdam, F., 2016, GDAL: Geospatial Data Abstraction Library (ver. 2.1): Open Source Geospatial Foundation, accessed July 1, 2018, at http://www.gdal.org/.

Westenbroek, S.M., Kelson, V.A., Dripps, W.R., Hunt, R.J., and Bradbury, K.R., 2010, SWB-A modified Thornthwaite-Mather soil-water balance code for estimating groundwater recharge: U.S. Geological Survey Techniques and Methods, book 6, chap. A31, 60 p. [Also available at https://pubs.usgs.gov/tm/tm6-a31/.]

Wolock, D.M., 2003, Estimated mean annual natural ground-water recharge in the conterminous United States: U.S. Geological Survey Open-File Report 2003-311. [Also available at https://pubs.er.usgs.gov/publication/ofr03311.]

Yager, R.M., Haj, A.E., Soller, D.R., Kauffman, L.J., Reddy, J.E., Buchwald, C.A., and Westenbroek, S.M., 2018, Digital products and databases used to develop a hydrogeologic framework for Quaternary sediments within the glaciated conterminous United States and to characterize aquifers within them: U.S. Geological Survey data release, https://doi.org/10.5066/F7HH6J8X. 
For additional information about this publication, contact:

Director, USGS Central Midwest Water Science Center

U.S. Geological Survey

400 South Clinton Street

Iowa City, IA 52240

or visit https://www.usgs.gov/centers/cm-water

Publishing support provided by the

Madison, Pembroke, and Rolla Publishing Service Centers 
